UNIVERSIDADE DE SÃO PAULO

INSTITUTO DE GEOCIÊNCIAS

\title{
A MODELAGEM MATEMÁTICA ASSOCIADA AO SISTEMA DE INFORMAÇÃO GEOGRÁFICA COMO INSTRUMENTO DE PREVISÃO NO ESTUDO DO IMPACTO HIDROGEOLÓGICO DE RESERVATÓRIOS
}

Malva Andrea Mancuso Paraiso Cavalcanti

Orientador: Prof. Dr. Alberto Pacheco

TESE DE DOUTORAMENTO

Programa de Pós-Graduação em Recursos Minerais e Hidrogeologia

SÃO PAULO

2002 
A MARCELO e RAFAEL, pelos incontáveis dias que deixamos de passar juntos para que eu pudesse concretizar meu sonho 


\section{AGRADECIMENTOS}

A realização desta pesquisa foi possível graças ao apoio de várias pessoas e instituições, as quais deixo registrado o meu agradecimento.

Ao Instituto de Pesquisas Tecnológicas do Estado de São Paulo (IPT), por ter permitido a minha dedicação a esta pesquisa.

Ao Prof. Dr. Alberto Pacheco, por sua orientação e apoio durante o desenvolvimento deste trabalho, e também durante toda a minha vida profissional.

Ao Prof. Dr. Jerald Schnoor, da University of lowa, por acreditar na utilização desta metodologia e me introduzir no estudo da modelagem matemática e do SIG.

Ao colega e amigo Geol. Dr. José Luiz Albuquerque Filho, pelas constantes discussões metodológicas e conceituais, e pelo seu incentivo nas horas mais difíceis.

Aos professores Dr. Aldo da Cunha Rebouças e Dr. Fábio Taioli, pelas discussões e sugestões formuladas durante a qualificação.

Aos geólogos Carlos Geraldo Luz de Freitas, Sérgio Gouveia de Azevedo e Ângelo José Consoni, pelas discussões, críticas e rigorosas revisões do texto.

Ao geólogo Antônio Gimenez Filho, pela grande ajuda nas questões geológicas e na elaboração do modelo conceitual.

Aos técnicos Antônio José Catib Baladore e José da Silva, pela ajuda durante a execução dos trabalhos de campo e na digitalização de mapas.

Aos técnicos Nodil A. Pereira e Álvaro C. Kopezynski pela plotagem e preparação de mapas.

À geóloga Lilian Maria Amstalden Baida e ao estagiário de geologia Tiago Mancini, pelo trabalho de padronização das referências bibliográficas.

Às funcionárias da Secretaria de Pós Graduação em Geociências Ana Paula Cabanal e Magali Poli Fernandes Rizzo, pelas inúmeras vezes em que me auxiliaram e orientaram nestes anos dedicados à pós-graduação.

Ao Departamento de Águas e Energia Elétrica (DAEE), na pessoa de Maria Isabel Faria Gouveia, coordenadora do Convênio DAEE/IPT, pela autorização para o uso dos dados do reservatório de Biritiba-Mirim e pelo apoio e colaboração no que foi preciso. 
Ao tecnólogo Gerson S. Almeida Filho, pelos freqüentes incentivos à realização do trabalho.

Ao Conselho Nacional de Desenvolvimento Científico e Tecnológico (CNPq) que contribuiu por meio de bolsa de estudo durante os primeiros anos de trabalho.

A BOSS International Inc. pela doação dos aplicativos matemáticos utilizados neste estudo.

Aos professores e funcionários do Departamento de Geologia Sedimentar e Ambiental (GSA) do Instituto de Geociências da Universidade de São Paulo, e aos colegas da Divisão de Geologia do Instituto de Pesquisas Tecnológicas do Estado de São Paulo - IPT, que direta ou indiretamente colaboraram com este trabalho. 


\section{SUMÁRIO}

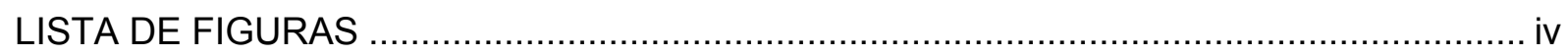

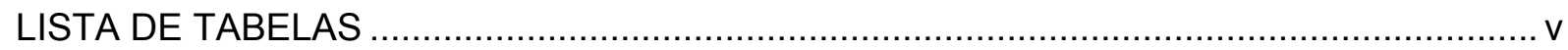

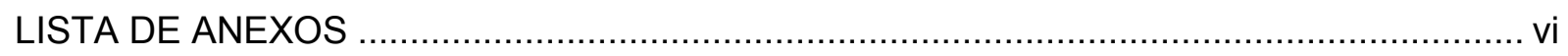

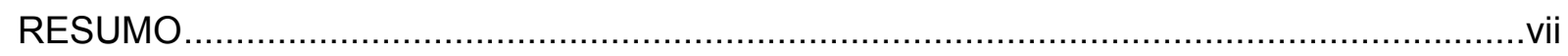

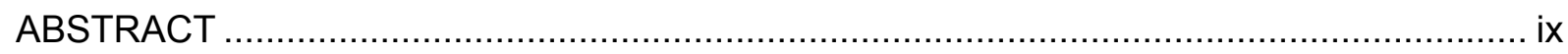

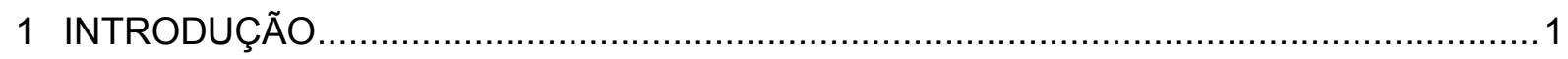

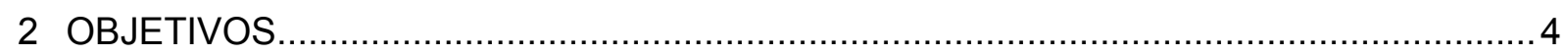

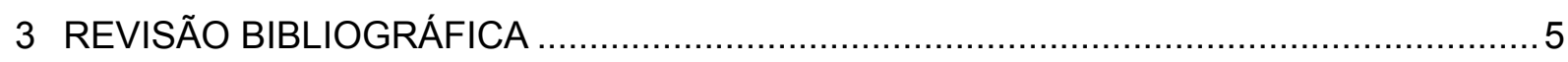

3.1 Métodos de prognóstico da elevação do nível freático............................................ 8

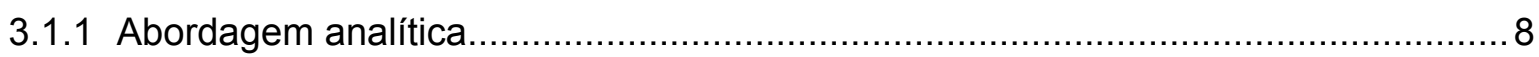

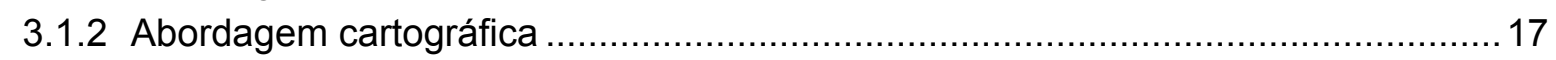

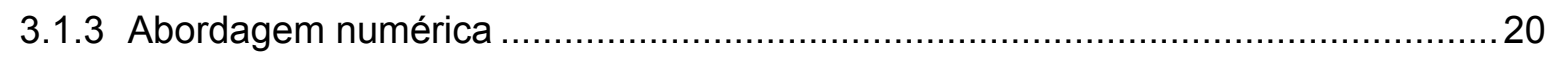

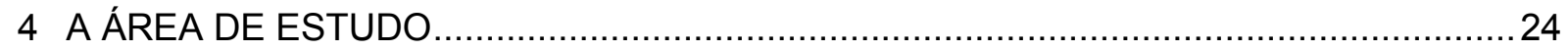

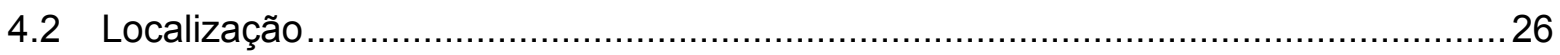

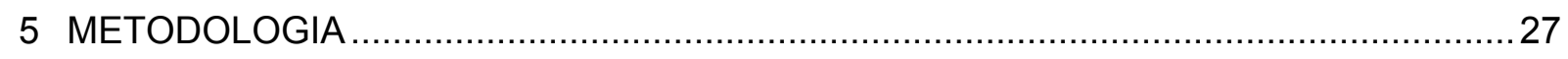

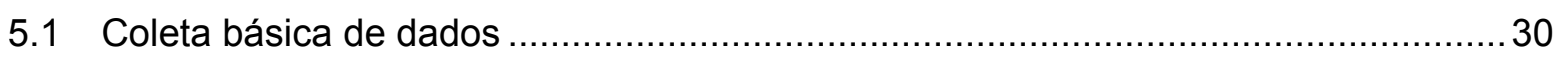

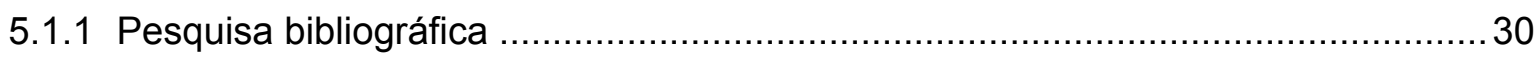

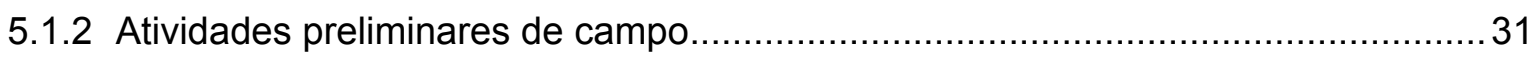

5.1.2.1 Cadastramento de captações de águas subterrâneas e nascentes................. 31

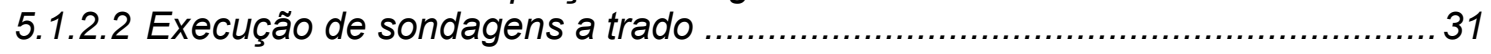

5.2 Concepção e elaboração do modelo matemático ................................................ 32

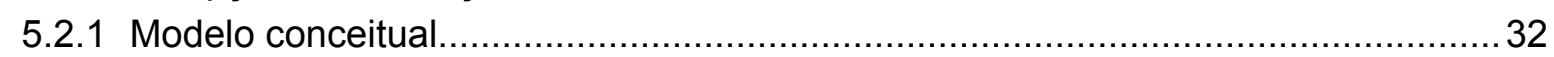

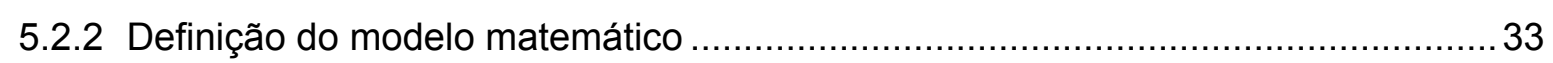

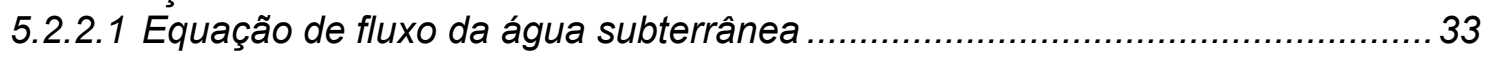

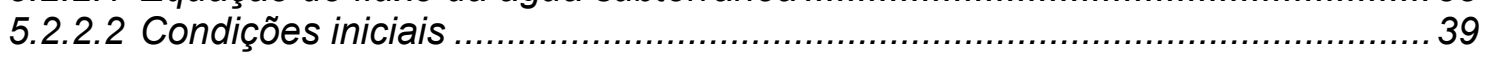

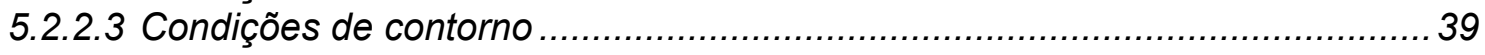

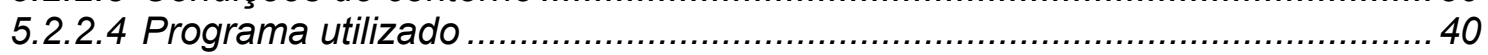

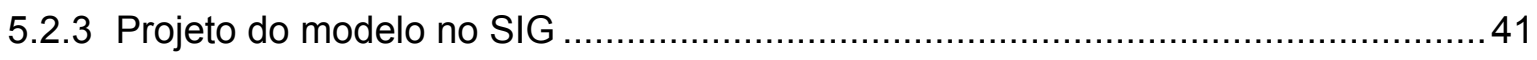

5.2.4 Calibração do modelo matemático ................................................................ 41

5.2.5 Primeira simulação do enchimento do reservatório ........................................... 42

5.2.5.1 Instalação de poços de monitoramento .................................................... 42

5.2.5.2 Posicionamento das estações de observação e de medição ........................... 43

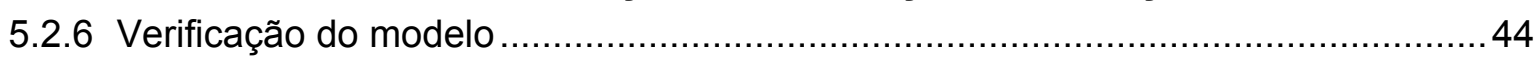

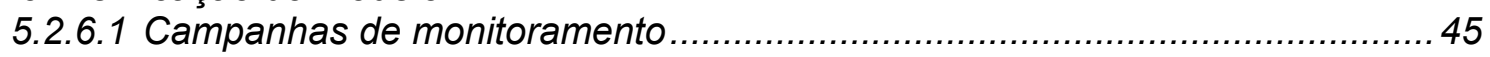

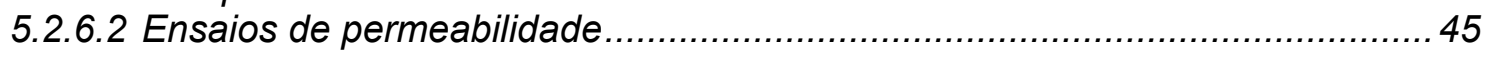


5.3 Elaboração do Mapa Previsional de Influência do reservatório sobre o aqüífero livre.

5.3.1 Áreas de destaque quanto ao uso e ocupação do solo na margem do reservatório....

5.3.2 Proposta de monitoramento do aqüífero ................................................ 47

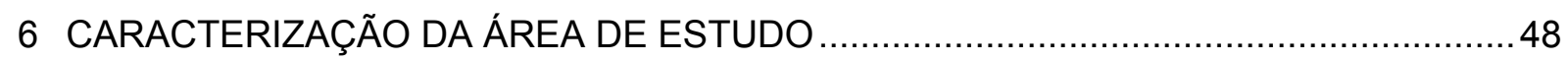

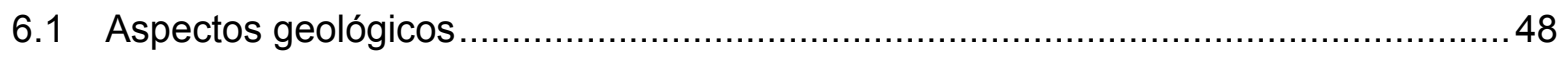

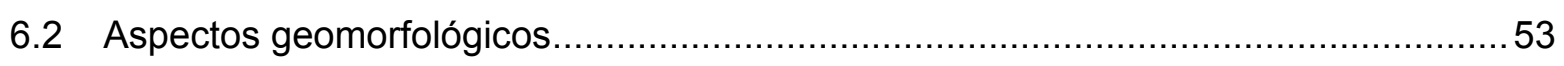

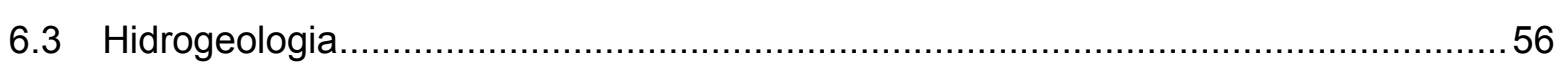

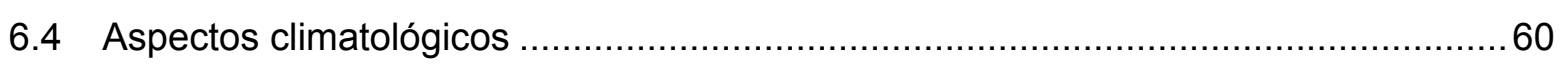

6.5 Características do uso e ocupação do solo na área bacia .....................................61

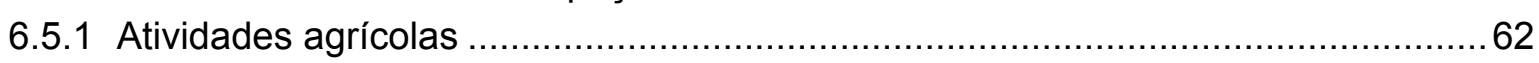

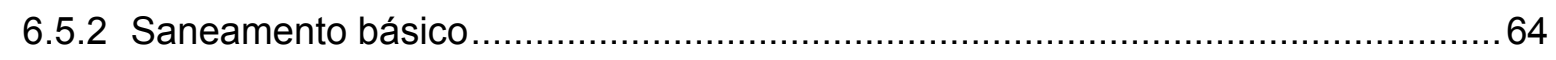

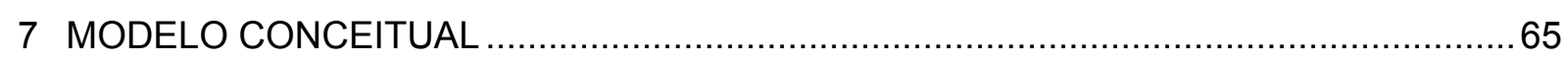

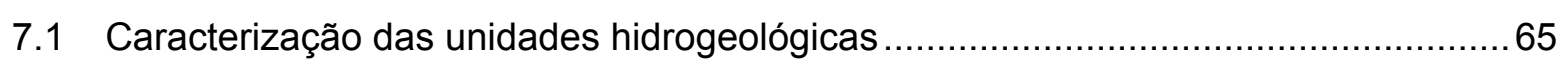

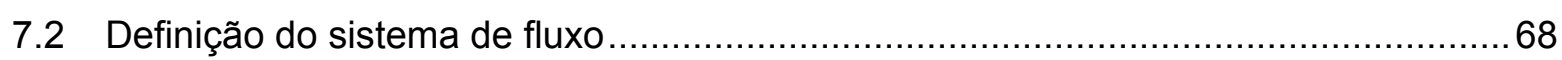

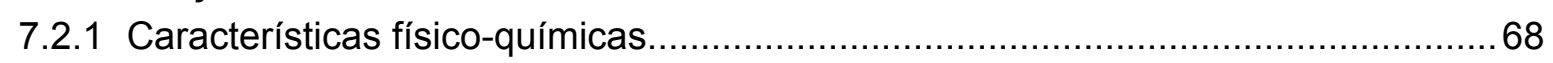

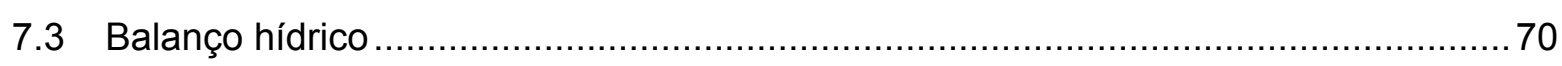

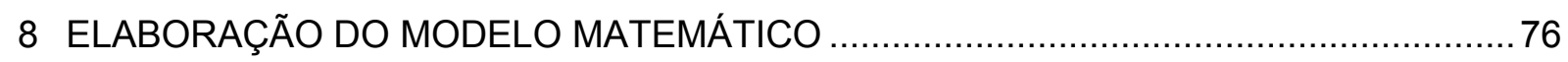

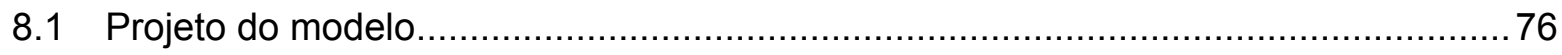

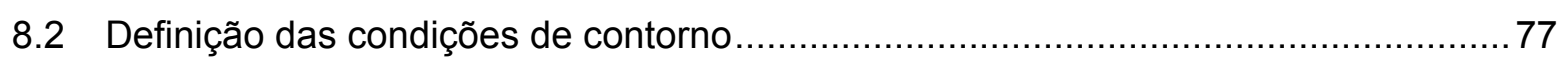

8.2 .1 Limites sem fluxo ou fluxo nulo .................................................................... 80

8.2.2 Limite de fluxo dependente da carga hidráulica ................................................ 80

8.2.3 Limites com carga hidráulica específica ....................................................... 81

8.3 Definição da condição inicial do sistema ............................................................... 81

8.4 Seleção inicial dos valores de parâmetros e estresses hidrológicos......................... 82

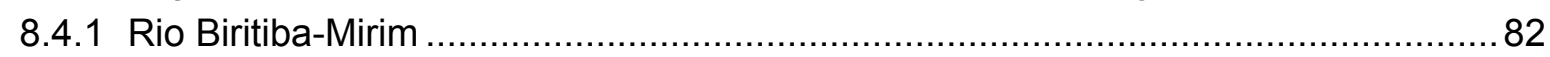

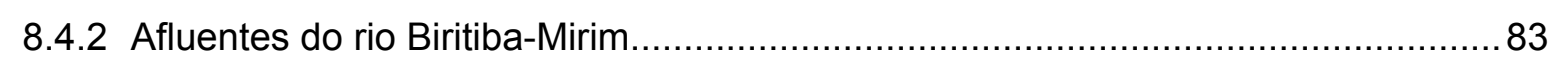

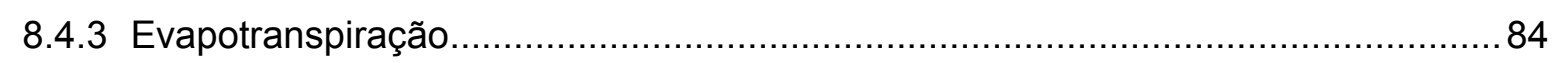

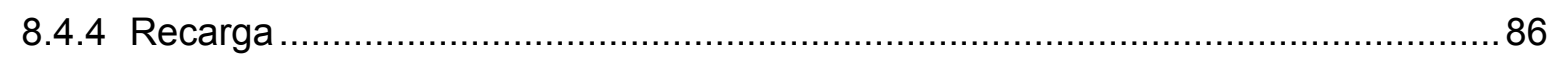

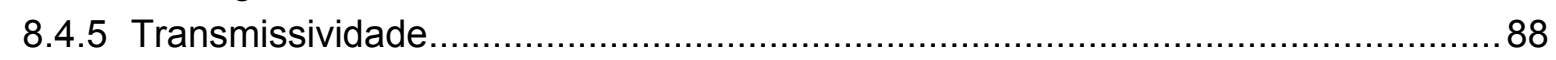

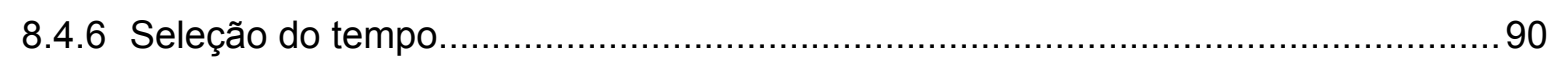

8.5 Transferência dos dados para o modelo matemático MODFLOW ...........................90

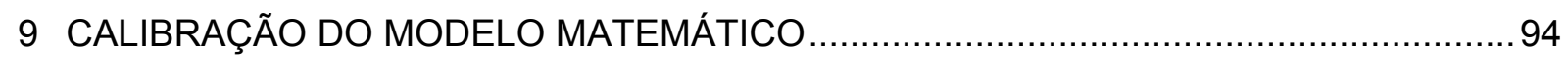

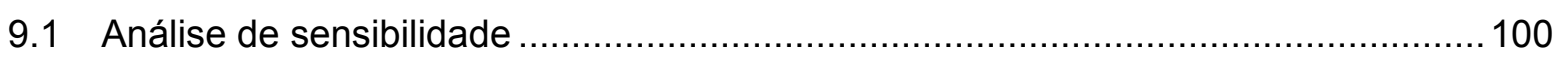

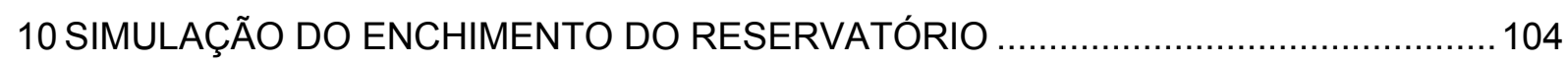

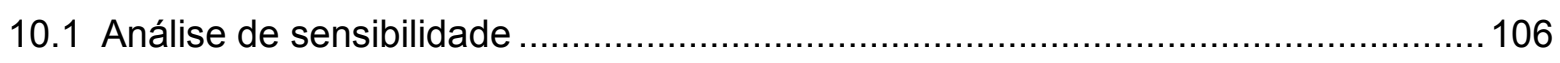

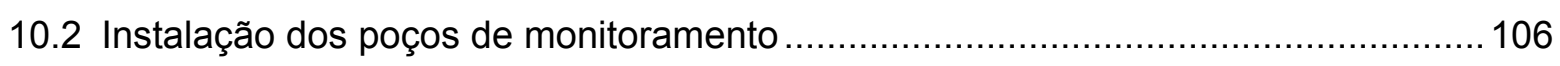




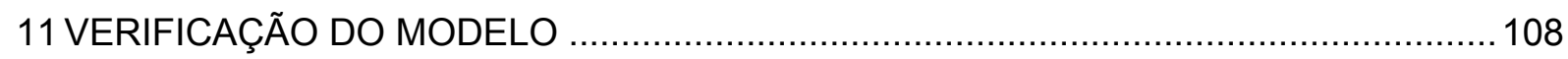

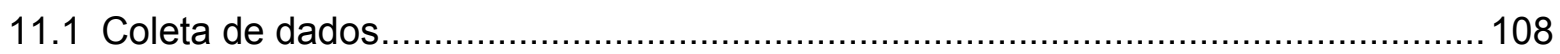

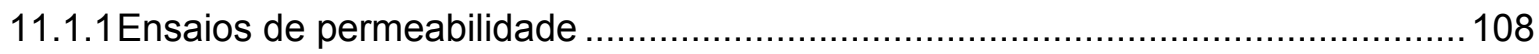

11.1.2Monitoramento anterior ao enchimento do reservatório ......................................... 109

11.1.3Cálculo de recarga para o período monitorado ..............................................110

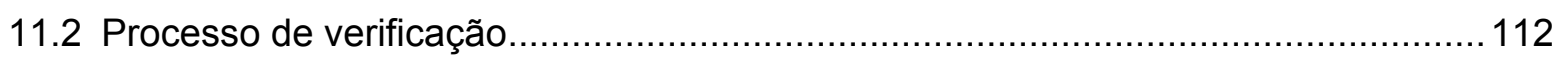

12 ELABORAÇÃO DO MAPA PREVISIONAL DE INFLUÊNCIA ......................................114

12.1 Áreas de destaque quanto ao uso e ocupação do solo nas margens do reservatório

12.1.1Análise da disposição de dejetos domésticos nas bordas do reservatório ............120

13 PROGRAMA DE MONITORAMENTO DO AQÜÍFERO FREÁTICO ..............................121

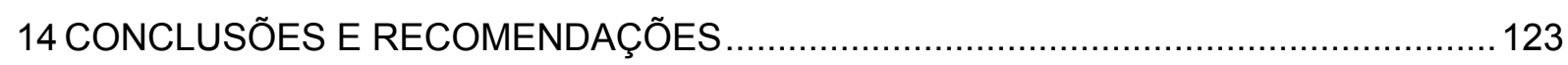

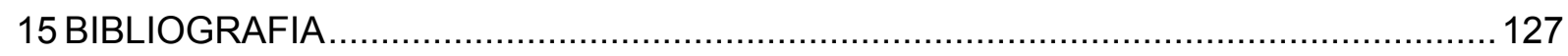




\section{LISTA DE FIGURAS}

FIGURA 3.1 - Modelo esquemático do processo de elevações induzidas no nível freático nas bordas de reservatórios

FIGURA 4.1 - Localização da barragem de Biritiba-Mirim no contexto das obras integrantes do Sistema Produtor Alto Tietê (SPAT) …............................ 25

FIGURA 5.1 - Roteiro metodológico utilizado na realização da pesquisa.........................29

FIGURA 5.2 - Representação do volume elementar de um aqüífero ................................. 36

FIGURA 5.3 - Estação DGPS itinerante, em operação para determinação das coordenadas de um poço de monitoramento

FIGURA 5.4 - Modelo esquemático de um poço de monitoramento e cálculo do coeficiente de permeabilidade do terreno $(K)$, aplicado em ensaios de rebaixamento.

FIGURA 6.1 - Unidades geológicas da bacia de drenagem do rio Biritiba-Mirim

FIGURA 6.2 - Unidades geomorfológicas da bacia de drenagem do rio Biritiba-Mirim ....55

FIGURA 6.3 - Mapa hidrogeológico da bacia de drenagem do rio Biritiba-Mirim .............57

FIGURA 7.1 - Transferência das informações geológicas para o modelo conceitual.......67

FIGURA 8.1 - Malha de células centralizadas utilizada na representação do modelo bidimensional do aqüífero livre .......................................................... 77

FIGURA 8.2 - Condições de contorno para a bacia de drenagem do rio Biritiba-Mirim....79

FIGURA 8.3 - Plano de Informação (coverage) fontes/sumidouros, do módulo MAP, da interface GMS (ECGL, 1996).

FIGURA 8.4 - Plano de Informação (coverage) aéreo, do módulo MAP, da interface GMS (ECGL, 1996).

FIGURA 8.5 - Plano de Informação (coverage) da camada (layer), do módulo MAP, da interface GMS (ECGL, 1996)...

FIGURA 8.6 - Plano de Informação (coverage) fontes/sumidouros (modelo conceitual), transferido para o modelo numérico

FIGURA 9.1 - Diagrama de decisão utilizado para a calibração do modelo matemático. 95

FIGURA 9.2 - Valores finais resultantes da calibração do parâmetro transmissividade. Plano de Informação (coverage) da camada aqüífera.

FIGURA 9.3 - Relação entre a carga hidráulica obtida no modelo calibrado e a observada em campo.

FIGURA 10.1 - Configuração final das células transferidas do Plano de Informação (coverage) fontes/sumidouros para o modelo numérico, na simulação do enchimento do reservatório

FIGURA 11.1 - Precipitação pluviométrica registrada na barragem de Biritiba-Mirim, entre abril/2000 e março/2001, e médias mensais históricas do posto de Salesópolis e da Estação Casa Grande. 


\section{LISTA DE TABELAS}

TABELA 6.1 - Uso do solo e a cobertura vegetal na área de inundação. ...........................62

TABELA 7.1 - Volumes utilizados para o cálculo do balanço hídrico.................................71

TABELA 7.2 - Cálculo do Coeficiente de Escoamento $(C)$ da bacia de drenagem dos rios Biritiba-Mirim/Biritiba Açu..............................................................73

TABELA 9.1 - Valores finais dos parâmetros do aqüifero que possibilitaram a calibração do modelo matemático............................................................97

TABELA 9.2 - Configuração final do balanço hídrico do modelo calibrado......................100

TABELA 9.3 - Análise de sensibilidade do modelo matemático construído......................103

TABELA 10.1 - Poços de monitoramento instalados na bacia de contribuição do reservatório de Biritiba-Mirim em maio/junho de 2000 ........................... 107

TABELA 11.1 - Precipitação pluviométrica durante o período de monitoramento do

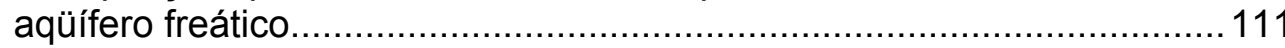

TABELA 11.2 - Valores de precipitação e evapotranspiração utilizados na verificação do modelo. 


\section{LISTA DE ANEXOS}

ANEXO A - Sondagens a trado realizadas na área de influência do reservatório de Biritiba-Mirim ................................................................................ 143

ANEXO B - Dados do cadastramento de poços realizado em novembro/dezembro 1999148 ANEXO C - Relação entre a carga hidráulica medida e a calibrada ............................... 152

ANEXOD - Poços de monitoramento instalados na bacia de contribuição do reservatório de Biritiba-Mirim ........................................................... 155

ANEXO E - Resultados dos testes de permeabilidade ............................................... 160

ANEXO F - Resultados do monitoramento de poços da bacia de drenagem do rio

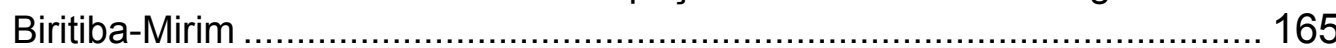




\section{RESUMO}

Esta pesquisa objetivou mostrar a viabilidade de utilização do Sistema de Informação Geográfica (SIG) associado à modelagem matemática, como opção metodológica a ser aplicada no estudo das modificações induzidas no nível freático, após o enchimento de reservatórios.

A área piloto escolhida foi a bacia de drenagem do rio Biritiba-Mirim, localizada na região do Alto Tietê, no Estado de São Paulo.

O entendimento do funcionamento do sistema hidrogeológico, obtido por meio de dados de geologia, hidrogeologia, climatologia, poços existentes e sondagens executadas na área, subsidiou a elaboração do modelo conceitual.

$\mathrm{Na}$ área, foram identificados dois tipos de aqüiferos: o Sedimentar, restrito às planícies fluviais e o Cristalino alterado, decorrente da alteração intempérica da rocha.

Os fluxos locais da água subterrânea ocorrem em direção aos cursos d'água que constituem a malha de drenagem da bacia, enquanto que, regionalmente, as águas subterrâneas fluem na direção do rio Biritiba-Mirim.

As informações do modelo conceitual foram, inicialmente, organizadas no Sistema de Informação Geográfica e, posteriormente, transferidas para o modelo matemático.

Foi construído um modelo matemático para a bacia de drenagem do rio BiritibaMirim utilizando o programa tridimensional de diferenças finitas MODFLOW desenvolvido por McDONALD \& HARBAUGH (1988).

A calibração do modelo foi executada a partir de ajustes sucessivos, efetuados por meio do SIG e, posteriormente, aferidos no MODFLOW.

Uma vez concluído o processo de calibração, procedeu-se à simulação do enchimento do reservatório, utilizando novamente o Sistema de Informação Geográfica para a entrada dos dados. A simulação, também realizada no MODFLOW, possibilitou delimitar as áreas nas quais os níveis das águas subterrâneas sofrerão maiores influências do reservatório, dando o subsidio necessário para a locação dos poços de monitoramento.

Os dados coletados no período de um ano de monitoramento permitiram executar a verificação e eventuais correções do modelo. 
Com o modelo aferido, repetiu-se a simulação do enchimento do reservatório e, a partir do mapa potenciométrico resultante, foi elaborado o mapa de profundidades de níveis d'água subterrânea previstas para após o enchimento do lago, denominado de Mapa Previsional de Influência. Nesse mapa foram delimitadas duas zonas de influência (de 0-5 m e de 5-10 m) e uma zona sem influência do reservatório ou com profundidade final do nível freático superior a $10 \mathrm{~m}$.

Finalmente, definiu-se um programa de monitoramento potenciométrico do sistema aqüífero livre para execução em situação posterior ao enchimento do reservatório, a fim de avaliar o tempo e tipo de resposta do aqüífero livre ao processo de enchimento e efetuar a retroanálise das previsões. De acordo com programa definido, a primeira campanha de medição deverá coincidir com o início do enchimento do reservatório, a partir desta, o monitoramento deverá ser mensal até os três primeiros meses e, posteriormente, trimestral até completar um ano após o enchimento.

A execução do presente estudo comprovou a viabilidade da aplicação do SIG, associado à modelagem matemática com fins previsionais, em escala de bacia de contribuição, para a avaliação das modificações induzidas no nível do aqüífero livre após o enchimento de reservatórios.

Recomenda-se a metodologia aqui proposta como ferramenta a ser aplicada em outros locais que apresentem a mesma problemática. 


\section{ABSTRACT}

The purpose of the current research was to demonstrate the viability of using Geographic Information System - GIS associated to mathematical models as a methodological option to be applied in the study of the water table elevation induced by dam reservoirs after their impoundment.

The chosen area was the drainage basin of Biritiba-Mirim river, located in Alto Tietê area, in São Paulo State.

The understanding of the hydrogeological system was acquired through geological, hydrogeological and climatological data. The surveys executed in the area, also allowed the construction of the conceptual model.

In the area, two aquifers types were identified: the Sedimentary, restricted to the fluvial plains, and the altered Crystalline, due to the weathering.

The regional groundwater flow was toward Biritiba-Mirim river, while the secondary drainage was a local groundwater discharge area.

The conceptual model data was, initially, organized in a Geographic Information System and later transferred to the mathematical model.

A mathematical model was built on the Biritiba-Mirim drainage basin using MODFLOW, a three-dimensional program of finite differences developed by McDONALD \& HARBAUGH (1988).

The model calibration was executed through successive trial-error process, using Geographic Information System as a input data and MODFLOW to evaluate results.

After the conclution of the calibration process, the Biritiba-Mirim reservoir impoundment was simulated using Geographic Information System to input the new variable.

The simulation, also accomplished in MODFLOW, made possible to limitate the main areas that will be impacted on their ground water levels. Using that map were located the monitoring wels.

From the monitoring data, collected in a year period, it was possible to verify the model.

The reservoir impoundment simulation was repeated. From the resulted potenciometric map, the groundwater final depths map was elaborated. In that map, 
named Predictional Influence Map, two influence zones were defined (0-5 m and $10 \mathrm{~m}$ ), and a zone without the reservoir influence or with final water table level more than 10 m depth.

Finally, an aquifer monitoring program was defined, in order to follow the water table impact after the reservoir impoundment. According to this program, two weeks after the impoundment should be made the first field measurement. The periodicity should be monthly until the first three months, and, after that, quarterly until the end of the first year.

The present study showed the viability of using Geographic Information System associated to mathematical models to predict modifications induced on the water table levels after a reservoir impoundment.

This methodology is recommended as an important tool to be applied in other cases with the same problem. 


\section{INTRODUÇÃO}

A geração de energia a partir do aproveitamento do potencial hidrelétrico, por meio da instalação de grandes barragens, tornou-se corrente no Brasil a partir da década de 60. Em 1999, o País registrava 2.200 usinas hidrelétricas, e o governo federal previa a necessidade de construção de 434 novas barragens até o ano 2015 (MELLO, 1999).

A construção dessas obras propicia ao homem a estratégica energia elétrica, renovável, não-poluente e mais barata, ao mesmo tempo em que regulariza rios e possibilita a implantação de corredores hidroviários; por outro lado, altera o equilíbrio ambiental e o uso e ocupação do solo no interior da área de inundação e nos entornos do lago (ALBUQUERQUE FILHO, 2002).

A preocupação de realizar estudos que permitissem caracterizar antecipadamente o problema, de forma que fosse possível prevenir ou mitigar os eventuais impactos negativos de reservatórios surgiu, no Brasil, na década de 1980. Tal preocupação foi decorrente de manifestações dos efeitos produzidos pela formação de reservatórios, implantados nas décadas de 1960 e 1970 nos estados de São Paulo e Mato Grosso do Sul. Esses problemas, associados ao uso e ocupação de terras, incluíam a elevação de nível d'água em cacimbas, o encharcamento de terrenos e o afogamento de fossas sépticas ou negras (SILVA et al., 1998).

Segundo ALBUQUERQUE FILHO et al. (1994), a importância dos estudos de impactos hidrogeológicos de enchimento de reservatórios, executados anteriormente à implantação da obra, está em possibilitar a prevenção, eventuais correções ou mitigações desses efeitos em áreas já ocupadas, propiciando uma ferramenta importante para o planejamento e uso de áreas ainda não ocupadas.

Do ponto de vista sócio-econômico, esses estudos são de grande importância no que se refere à previsão de adoção de medidas compensatórias necessárias, que possam ser acordadas entre a empresa responsável pela implantação do reservatório e as comunidades afetadas pelos impactos negativos decorrentes.

A partir da segunda metade da década de 80 , a legislação ambiental brasileira passa a exigir claramente estudos para caracterizar de forma global e em fase préenchimento, dos possíveis efeitos da implantação de barragens. Foi em 1986, com a 
Resolução CONAMA № 01/86 (BRASIL, 1997), que passaram a ser exigidas avaliações prévias de impactos, como condicionadoras do licenciamento de atividades antrópicas modificadoras de aspectos e recursos ambientais. Dentre essas atividades, é incluída a instalação de usinas de geração de eletricidade. Em 1987, a Resolução CONAMA № 06 (BRASIL, 1997) regulamenta o licenciamento ambiental no setor elétrico, estabelecendo a exigência de três licenças: Licença Prévia (LP), Licença de Instalação (LI) e Licença de Operação (LO).

De acordo com a COMISSÃO MUNDIAL DE BARRAGENS (CMB, 2000), os esforços para amenizar os impactos ambientais negativos das grandes barragens sobre ecossistemas tiveram sucesso limitado, devido ao descaso em se prever tais impactos; à má qualidade e pouca confiabilidade dos prognósticos; à dificuldade de enfrentar todos os impactos; e à implementação e sucesso apenas parcial das medidas de mitigação ambiental.

A mitigação eficiente dos impactos negativos resulta, em parte, da qualidade das informações e da realização de monitoramentos constantes e revisões periódicas (CMB, op. cit.). A importância da utilização de metodologias que permitam prever as conseqüências finais das alterações induzidas antes da execução dos projetos, está na possibilidade de prever seus efeitos colaterais e avaliar seu custo/benefício (KAZMANN, 1964).

A utilização de modelos matemáticos nos estudos de águas subterrâneas, de acordo com ANDERSON \& WOESSNER (1992), é o melhor caminho para realizar previsões adequadas acerca das conseqüências de uma determinada ação proposta.

No entanto, a modelagem matemática requer conhecimento mais detalhado do sistema a ser modelado, comparativamente às metodologias mais simples. Um dos principais desafios, no caso, é a transferência desse conhecimento para o modelo numérico.

Atualmente, o Sistema de Informação Geográfica (SIG) permite a criação e organização de bases de dados georeferenciados. Com a utilização de técnicas recentes, é possível a transferência dessas informações georeferenciadas diretamente para os modelos matemáticos. Dessa maneira, a associação do Sistema de Informação Geográfica com a modelagem matemática vem subsidiar a simulação de sistemas e problemáticas mais complexas. 
O estudo pretende demonstrar a viabilidade técnica da aplicação conjugada desses dois instrumentos no estudo das modificações induzidas no nível freático, em decorrência do enchimento de reservatórios. 


\section{OBJETIVOS}

O objetivo desta pesquisa foi avaliar a aplicabilidade da modelagem matemática de fluxos subterrâneos associada ao Sistema de Informação Geográfica, na determinação previsional das elevações induzidas em aqüiferos livres, em decorrência do enchimento de reservatórios.

A partir da metodologia proposta, pretendeu-se:

a) destacar as áreas mais suscetíveis à influência hidrogeológica do reservatório estudado (na escala 1:25.000);

b) estabelecer plano de monitoramento hidrogeológico para o reservatório como um todo; e

c) propiciar um instrumento de planejamento do uso e ocupação de áreas no entorno do reservatório, na forma de plantas previsionais de influência do enchimento.

A partir da pesquisa desenvolvida, procurou-se demonstrar as aplicações e limitações da utilização do Sistema de Informação Geográfica associado à modelagem matemática de fluxos subterrâneos na previsão do impacto hidrogeológico de reservatórios, em escala de bacia de contribuição. 


\section{REVISÃo BIBLIOGRÁFICA}

$\mathrm{Na}$ elaboração de estudos de impactos ambientais, um dos problemas que se apresenta é a necessidade de prognóstico da amplitude e extensão da elevação do nível freático nas margens do futuro reservatório. A instalação de reservatórios, condicionando uma nova posição no nível de descarga do aqüífero livre acima do nível freático natural, provocará infiltração e armazenamento nos bancos marginais (bank storage) e efetivas trocas de água reservatório-aqüífero, resultando em elevação generalizada no nível do aqüífero freático regional CRUZ \& VERSIANI (1990).

De acordo com MEDOVAR \& AKHMETYEVA (1984), a formação de uma zona de nível freático mais elevado, a partir do enchimento do reservatório, se processa em duas fases. A primeira fase ocorre quando o nível d'água natural do rio é modificado para um patamar mais elevado, resultando em infiltração (seepage) através das suas bordas, gerando uma frente de saturação que se confrontará com o fluxo subterrâneo natural, formando uma zona de depressão na água subterrânea (hollow), no encontro entre os dois fluxos.

Essa primeira fase se prolonga enquanto perdurar a condição de fluxo transitório, onde ocorre a recarga a partir do reservatório. O eixo da depressão se aproxima da margem do reservatório até que o processo cesse e se constitua uma segunda fase. Nesta, os fluxos subterrâneos são retomados para o sentido inicial (do aqüífero para o rio/reservatório), porém com gradientes mais suaves (FIGURA 3.1).

Em 1984, BOTTURA \& SANTOS (1984) denominaram de Impacto Hidrogeológico de Reservatórios as elevações induzidas pelo enchimento de reservatórios e os seus efeitos no uso e ocupação do solo. 


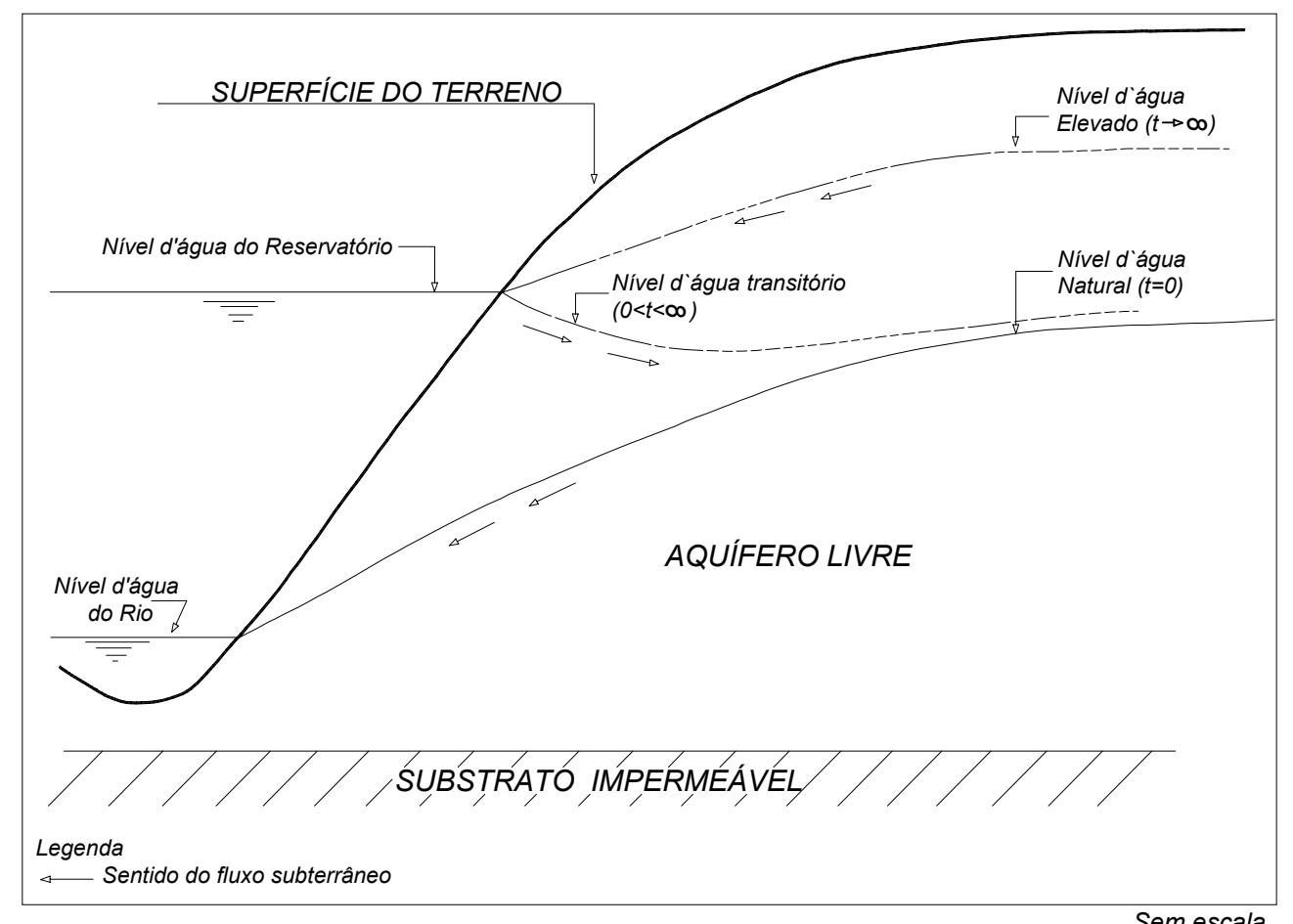

Fonte: ALBUQUERQUE FILHO et al. (1996).

FIGURA 3.1 - Modelo esquemático do processo de elevações induzidas no nível freático nas bordas de reservatórios

De acordo com ALBUQUERQUE FILHO (1995), podem ser destacadas as seguintes alterações potenciais no meio físico adjacente ao reservatório, após o seu enchimento:

1) afloramento do nível freático, particularmente em zonas topograficamente deprimidas;

2) aumento da espessura saturada do aqüífero;

3) aporte de volumes de ágı e características físico-químicas diferentes;

4) diminuição dos gradientes hidráulicos subterrâneos;

5) aumento da vulnerabilidade à contaminação; e

6) colapsos no solo.

Essas alterações, porém, podem ser benéficas ou não, dependendo das condições iniciais da área e da sua localização em relação ao reservatório. Dentre as 
principais repercussões negativas potenciais, no que se refere ao uso e ocupação do solo, destacam-se (ALBUQUERQUE FILHO, 2002):

1) perda de pontos de captação instalados;

2) perda de produtividade de solos agricultáveis (afogamento de raízes, salinização, dentre outros);

3) restrição de usos da água subterrânea;

4) recalque em subleito de vias, fundações e danos em edificações;

5) danificação em redes de água, esgoto ou outras tubulações;

6) infiltração de água em estruturas subterrâneas;

7) umidificação ou saturação de sepulturas em cemitério, com possibilidade de saponificação de cadáveres;

8) geração, reativação ou aceleração de processos erosivos lineares; e

Em relação às repercussões positivas, podem ser destacadas (ALBUQUERQUE FILHO, op. cit.):

1) aumento das reservas de águas subterrâneas;

2) maior facilidade de acesso aos recursos hídricos subterrâneos;

3) melhoria da umidade subsuperficial dos solos;

4) melhoria no desenvolvimento de árvores que demandam muita água;

5) perenização de cursos de água anteriormente intermitentes; e

6) formação de lagos em zonas deprimidas topograficamente.

Outro fato importante foi observado por MEDOVAR \& AKHMETYEVA (1984), após a instalação de reservatórios em rios da antiga URSS (União das Repúblicas Socialistas Soviéticas). Os autores constataram que o volume acrescentado no armazenamento de água do aqüífero livre adjacente, supera a quantidade acumulada na bacia superficial a montante da barragem do próprio reservatório.

Na Polônia, LOZINSKA-STEPIEN \& POZNIAK (1979) também observaram a formação de importantes reservas subterrâneas após a formação de um grande reservatório. 
A quantificação das elevações induzidas no aqüífero freático pelo enchimento de reservatórios pode ser efetuada utilizando-se diferentes métodos, que variam em complexidade e precisão. Apresentam-se, a seguir, alguns desses métodos propostos.

\subsection{Métodos de prognóstico da elevação do nível freático}

Os métodos de prognósticos mais utilizados podem ser agrupados, de acordo com a sua abordagem, em três categorias distintas: a abordagem analítica, a cartográfica, e a numérica, detalhadas a seguir.

\subsubsection{Abordagem analítica}

Os métodos analíticos permitem definir as variações de carga hidráulica no aqüífero adjacente ao reservatório, após o barramento e a montante do corpo da barragem, utilizando-se de equações que podem ser resolvidas em calculadoras ou planilhas de cálculo.

Dentre os primeiros tipos de métodos analíticos, encontra-se o proposto por REED \& BEDINGER (1962), que sugere a adaptação da equação utilizada por Slichter (apud REED \& BEDINGER, 1962), para calcular a distribuição das variações de carga hidráulica no aqüífero, causadas pelas modificações no nível d'água natural do rio.

REED \& BEDINGER (op. cit.) consideraram que a variação no nível d'água do rio tem comportamento aproximadamente linear e que se estende ao longo de todo o canal do curso d'água até o remanso do futuro lago. Pela metodologia proposta, a montante do ponto-extremo do remanso do reservatório e a jusante da barragem, a variação no nível d'água do rio pode ser considerada desprezível.

A equação resultante é:

$$
\Delta h=\frac{1}{\pi}\left[\left(H-\frac{H y}{a}\right)\left(\arctan \frac{a-y}{x}+\arctan \frac{y}{x}\right)+\frac{H y}{2 a} \ln \left(\frac{x^{2}+y^{2}}{x^{2}+(a-y)^{2}}\right)\right]
$$


Sendo:

$\Delta h=$ variação de carga hidráulica no ponto $(x, y)$ do aqüífero [L]

$H$ = espessura da lâmina d'água do reservatório na altura do eixo da barragem $[\mathrm{L}]$

$H_{y}$ = espessura da lâmina d'água ao longo da borda do reservatório [L]

$a=$ extensão do reservatório [L]

$y$ = distância do eixo da barragem, medida ao longo do curso d'água/reservatório [L]

$x$ = distância perpendicular da borda do reservatório [L]

As condições de contorno ao longo da borda do futuro reservatório, ou seja, caso $\mathrm{x}=0$, podem ser expressas da seguinte forma:

a) $F(y)=0$, se $y<0$ (a jusante da barragem) ou $y>a$ (a montante do remanso do reservatório);

b) $F(y)=H-H_{y} / a$, se $0<y<a$ (ao longo do reservatório).

Sendo,

$F(y)=$ variação na cota do nível d'água ao longo do limite do curso d’água/reservatório [L]

O método proposto considera que o sistema de fluxo se encontra em equilíbrio (fluxo estacionário) e é restrito a condições de canais de rios retilíneos, podendo resultar em erro se for aplicada em área com meandros REED \& BEDINGER (op. cit.).

Estudando a formação de grandes reservatórios na ex-URSS, MEDOVAR \& AKHMETYEVA (1984) constataram que a construção dos mesmos influenciava significativamente as condições naturais das áreas adjacentes.

De acordo com os autores, a percolação da água no subsolo, provocada pelo enchimento de reservatórios, alimenta os aqüíferos existentes e cria outros. O volume de água acumulado pode, em alguns casos, superar aquela quantidade represada em superfície pela barragem, criando uma zona saturada artificial, que pode ser explorada para o abastecimento e irrigação.

Estudos realizados no reservatório de Ivankovo, (localizado na antiga URSS), que possui uma lâmina de água de até $18 \mathrm{~m}$, indicaram que, apesar do processo de enchimento ter demorado cerca de um ano para ser concluído, a massa de água do reservatório é totalmente renovada 14 vezes por ano. De acordo com MEDOVAR \& 
AKHMETYEVA (1984), a diferença entre a velocidade de enchimento e a de renovação é explicada pelo processo de infiltração e saturação inicial, a partir da base e bordas do reservatório.

Os autores sugerem a utilização da equação proposta por Verigin (apud MEDOVAR \& AKHMETYEVA, op. cit.), para calcular a elevação do nível d'água subterrânea nas vizinhanças de reservatórios.

$$
\Delta h=\Delta h_{0} \operatorname{erfc}\left(\frac{x}{2 \sqrt{a t}}\right) \quad \text { ou } \quad \Delta h=\Delta h_{0} \operatorname{erfc}(u)
$$

Sendo,

$\Delta h$ = elevação do nível d'água subterrânea em ponto à distância $\mathrm{x}$ da borda do reservatório [L]

$\Delta h_{o}=$ amplitude de elevação do nível d'água subterrânea na borda do reservatório [L]

$x$ = distância a partir da borda do reservatório ao longo de uma seção considerada [L]

$t$ = tempo a partir do início da infiltração oriunda do enchimento do reservatório $[\mathrm{T}]$

$\alpha=$ coeficiente de difusividade hidráulica, caracterizando a taxa de variação no nível d'água subterrânea no curso do fluxo não-estacionário $\left[\mathrm{L}^{2} \mathrm{~T}^{-1}\right]$

A função $\operatorname{erfc}(u)$ que aparece na Equação (3.2) é denominada de "função de erro complementar", estudada por Jahnke e Emde (apud WESSELING, 1979), cuja solução, para diferentes valores considerados de $(u)$, pode ser encontrada na forma de resultados tabelados (HUISMAN, 1972).

O coeficiente de difusividade hidráulica pode ser obtido por meio da seguinte equação:

$$
\alpha=\frac{K h_{a v}}{\mu}
$$


Sendo:

$h_{a v}=$ espessura média do fluxo [L]

$K=$ condutividade hidráulica do aqüifero $\left[\mathrm{LT}^{-1}\right]$

$\mu \quad=$ déficit de saturação [adim.]

A espessura média do fluxo é dada por:

$h_{a v}=0,05\left(h_{\text {max }}+h_{\text {min }}\right) \beta$

Onde:

$h_{\text {máx }}$ e $h_{\min }=$ espessura de fluxo máxima e mínima, nos limites externos do aqüífero $(x=0$ e $x=\mathrm{L})[\mathrm{L}]$

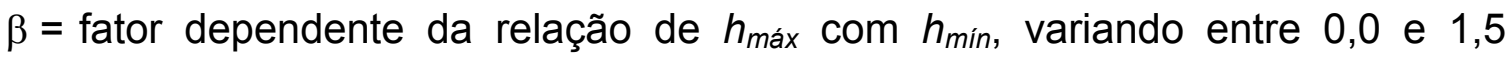
[adim.]

Segundo MEDOVAR \& AKHMETYEVA (1984), a elevação do nível d'água subterrânea é estimada assumindo-se como instantâneo o processo de enchimento do reservatório.

Com o objetivo de aprofundar o estudo do problema e indicar a necessidade de detalhamento em áreas específicas ou de risco, CRUZ \& VERSIANI (1990) propuseram a aplicação de soluções analíticas para realizar avaliação rápida da elevação do nível freático induzida pela instalação de reservatórios no Brasil. $O$ método permitiria o planejamento do monitoramento pós-enchimento, possibilitando a verificação da previsão dos resultados a partir dos dados obtidos no monitoramento.

Para as estimativas das elevações do nível d'água subterrânea, os autores utilizaram dois métodos distintos: o método de armazenamento nos bancos marginais (bank storage) e o método de drenos paralelos, no caso do vale do rio ou calha do reservatório funcionar como dreno. Esses métodos foram utilizados no estudo de duas áreas, ao norte do Estado de Minas Gerais (rio Pardo) e ao sudoeste do Estado de São Paulo (rio Paranapanema).

No caso do armazenamento nos bancos marginais (bank storage), CRUZ \& VERSIANI (1990) utilizaram as formulações de GLOVER (1985), que considerou um reservatório, com bancos marginais permeáveis que permaneceu cheio por um longo tempo e, então, sofreu processo de rebaixamento no seu nível d'água, sendo 
alimentado pela água subterrânea do aqüífero freático, outrora sustentado pelo nível do reservatório.

CRUZ \& VERSIANI (op. cit.) propuseram a utilização da equação desenvolvida por GLOVER (op. cit.) em situação inversa, ou seja, considerando um reservatório com bancos laterais permeáveis que, após uma fase de enchimento, passa a ocupar cota mais elevada. As modificações na posição do nível freático ao longo do tempo e para diferentes distâncias da borda do reservatório, foram calculadas, para regime transitório, com fluxos unidirecionais e para pequenas elevações em relação à sua espessura saturada total.

A equação resultante é a mesma que a proposta por Verigin (apud MEDOVAR \& AKHMETYEVA, 1984) (Eq. 3.2). As principais diferenças estão no cálculo da difusividade hidráulica (Eq. 3.3), na qual o déficit de saturação ( $\mu$ ) é substituído pelo coeficiente de armazenamento $(S)$; e na obtenção da espessura média do fluxo $\left(h_{a v}\right)$ (Eq. 3.4), calculada como a parcela da espessura saturada do aqüífero, entre a base impermeável e o datum considerado pelo nível d'água final do reservatório $(d)$.

No caso dos drenos paralelos, a distribuição da profundidade do nível d'água subterrânea nas laterais do reservatório pode ser calculada a partir do método de Moody, descrito por CRUZ \& VERSIANI (1990). O método compreende a solução da equação diferencial não linear de fluxo em drenos paralelos. A partir da equação de Moody, propõe a utilização de uma tabela que fornece, para diferentes posições do dreno entre a superfície freática e o substrato impermeável, a profundidade drenável $\left(h_{m}\right)$ no ponto intermediário entre os drenos no tempo $(t)$.

Para a aplicação do método no caso de reservatórios, CRUZ \& VERSIANI (op. cit.) correlacionaram um dos drenos, representado pelo reservatório, com a idealização de drenos paralelos. Os autores adaptaram o método proposto, considerando que a espessura saturada máxima ocorre no limite da borda impermeável.

No caso, a sistemática é idealizada para as seguintes condições:

a) sistema de fluxo em equilíbrio (fluxo estacionário);

b) cotas do nível d'água do aqüífero superiores àquelas do rio ou reservatório, que funciona como dreno; e

c) rebaixamentos pequenos em relação à espessura saturada do aqüífero. 
No estudo comparativo de um caso simulado, CRUZ \& VERSIANI (1990) constataram total correspondência entre os resultados obtidos a partir da equação de bank storage (GLOVER, 1985) e a simulação efetuada a partir do modelo numérico PLASM de PRICKETT \& LONNQUIST (1971), que soluciona a equação do fluxo bidimensional pelo método de diferenças finitas e simula as condições de recarga induzida pela da conexão rio-aqüífero.

A mesma comparação foi realizada com os resultados de três casos de rebaixamento simulados. De acordo com os autores, ocorre boa correspondência entre a solução obtida pelo método de Moody e a obtida pelo modelo PLASM.

GUO (1997) também estudou fluxos entre drenos ou trincheiras e aqüíferos livres, considerando dois casos em sua análise:

a) o nível d'água no reservatório sofre um rebaixamento instantâneo; e

b) o nível d'água do reservatório é elevado instantaneamente.

O autor desenvolveu técnicas de solução que resultaram na equação analítica linearizada para $(h)$ e para $\left(h^{2}\right)$.

No caso de (h), a linearização conduziu aos mesmos resultados da proposta de bank storage de CRUZ \& VERSIANI (op. cit.), para o cálculo das elevações induzidas pelo enchimento de reservatórios sobre aqüiferos livres adjacentes.

No caso de $\left(h^{2}\right)$, foi obtida a seguinte formulação:

$$
h^{2}=\left[h_{1}^{2}+\left(h_{0}^{2}-h_{1}^{2}\right)\right] \operatorname{erf}(u)
$$

Sendo,

$h$ = carga hidráulica do aqüifero [L]

$h_{0}=$ nível d'água inicial no reservatório, em relação ao mesmo datum considerado para a carga hidráulica [L]

$h_{1}$ = nível d'água modificado instantaneamente no reservatório, em relação ao mesmo datum considerado para a carga hidráulica [L]

$h_{m}$ = espessura saturada representativa do aqüífero [L]

Para utilizar a Eq. 3.5, os resultados tabelados para diferentes valores de (u) podem ser encontrados em HUISMAN (1972). 
GUO (1997) chamou a atenção para a questão da definição do parâmetro $\left(h_{m}\right)$, pois a definição da espessura saturada representativa afeta significativamente os resultados dos cálculos. O referido autor indica, como uma das opções para o cálculo representativo da espessura média do fluxo, a proposta de MEDOVAR \& AKHMETYEVA (1984), onde $\left(h_{m}\right)$ é igual à média entre a espessura do aqüifero no extremo externo e aquela obtida na borda do reservatório.

GUO (op. cit.) constatou que o melhor resultado para a linearização é a solução para $\left(h^{2}\right)$ pelo fato preservar parcialmente o efeito da não-linearidade.

O pesquisador australiano LOCKINGTON (1997) desenvolveu um método para avaliação de descargas e recargas de aqüífero livre por meio de um dreno ou trincheira totalmente penetrante, a partir da equação não-linear de Boussinesq, assumindo-se as hipóteses simplificativas de Dupuit para fluxo horizontal.

LOCKINGTON (op. cit.) apresenta as seguintes equações para determinar a posição do nível freático ao longo de drenos totalmente penetrantes no meio aqüífero:

$$
h=h_{0}+\left(h_{1}-h_{0}\right)\left(1-\frac{x}{\lambda} \sqrt{\frac{S}{K t}}\right)^{\frac{1}{\mu}}
$$

Para cálculo de $\lambda$ :

$$
\lambda^{2}=\frac{(1+\mu)(1+2 \mu)}{2 \mu^{2}}\left(h_{0}+h_{1}\right)
$$

Para o cálculo de $\mu$ :

$$
\mu=-\frac{3}{4}(1+n)+\frac{n}{(2-A)}+\frac{\left[(2-A)^{2}(1+2 n)+n^{2}(2+A)^{2}\right]^{\frac{1}{2}}}{4(2-A)}
$$


Sendo:

$$
\begin{gathered}
n=2,27932-\frac{3 h_{0}}{\left(h_{1}+2 h_{0}\right)} \\
A=\frac{4\left[h_{0}+(1+n) h_{1}\right]}{(1+n)(2+n)\left(h_{1}+h_{0}\right)}
\end{gathered}
$$

Para as equações (3.6) a (3.10), os parâmetros têm o seguinte:

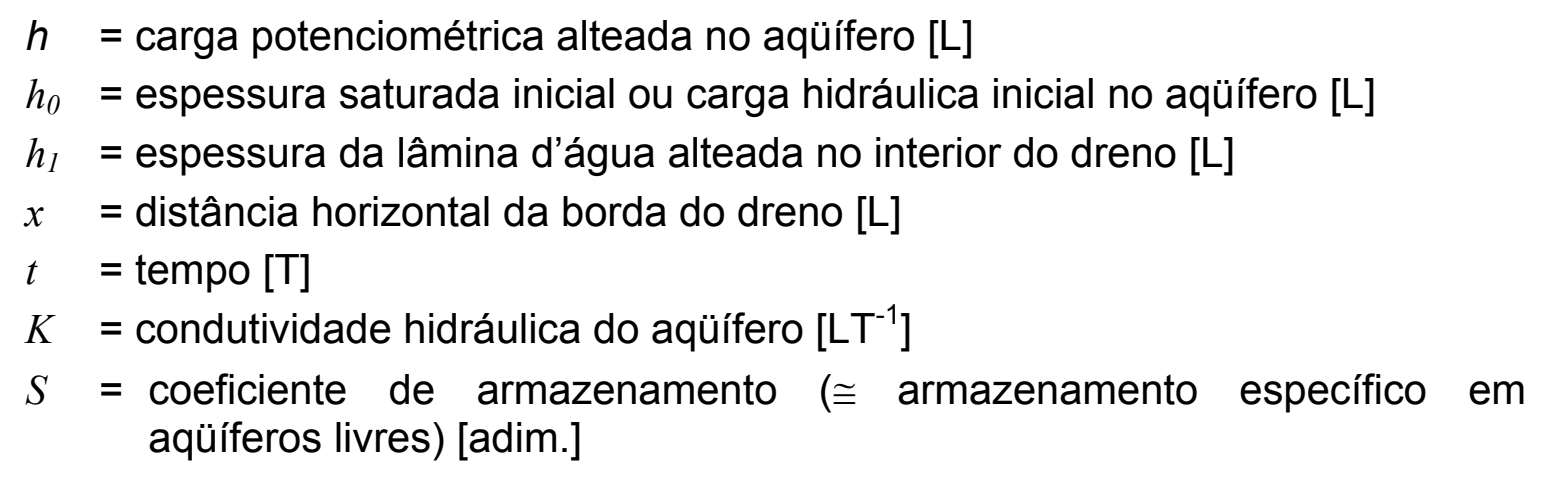

LOCKINGTON (1997) conclui que a equação não-linear de Boussinesq foi solucionada conduzindo a uma solução algébrica elementar, que poderá ser aplicada em aqüíferos de extensão finita, até que o nível freático manifeste modificações na borda do aqüífero.

Diversos estudos realizados em reservatórios brasileiros têm utilizado a equação proposta por Edelman (apud HUISMAN, 1972), para estimar a distribuição espacial e temporal das elevações que possam ocorrer na posição do nível freático do aqüífero adjacente, após o enchimento de reservatórios (MISTRETTA \& BOTTURA, 1986; ALBUQUERQUE FILHO et al., 1996).

O método baseia-se na adaptação de equações que governam os fluxos d'água subterrânea no entorno de canais ou drenos, instalados em aqüíferos livres, após mudanças ocorridas no nível d'água no seu interior (rebaixamentos ou elevações), conforme descrito em WESSELING (1979) e HUISMAN (1972) .

A equação resultante é igual à proposta por GLOVER (1985) e utilizada por CRUZ \& VERSIANI (1990); e similar à de Verigin (apud MEDOVAR \& AKHMETYEVA, 1984) (Eq. 3.2), com a diferença que o autor não indica um cálculo específico para a 
obtenção da espessura saturada do aqüífero livre $(d)$ e que o déficit de saturação $(\mu)$ é substituído pelo coeficiente de armazenamento $(S)$.

Os métodos analíticos são mais fáceis de utilizar que os numéricos, entretanto são menos precisos, pois envolvem, em geral, simplificações. A principal delas tem origem nas Hipóteses Simplificativas de Dupuit-Forchheimer (CUSTÓDIO \& LLAMAS, 1996), que pressupõem a seguinte condição:

a) em qualquer ponto do aqüífero a velocidade do fluxo tem direção horizontal; e

b) o gradiente hidráulico no plano vertical é constante e igual à inclinação da superfície d'água do aqüífero livre.

As equações analíticas são válidas para rebaixamentos/elevações pequenas em relação à espessura saturada do aqüífero. Além disso, os métodos pressupõem a presença de um canal ou dreno totalmente penetrante num aqüífero de espessura constante e extensão finita, homogêneo e isotrópico, com fluxo livre e horizontal, e em condição estacionária.

Esses pressupostos desconsideram importantes fatores que variam com o tempo e que afetam o sistema, como é o caso da recarga a partir da precipitação, a descarga por evapotranspiração, a explotação de água através de poços, dentre outros.

Trabalhos realizados por CRUZ \& VERSIANI (1990) indicaram que algumas soluções analíticas são válidas para identificar a extensão e amplitude das variações do nível freático, por efeito de construção de reservatórios, mesmo quando aplicados a rebaixamentos/elevações que poderiam ser considerados excessivos em relação à espessura saturada do aqüífero. De acordo com os autores, soluções analíticas constituem-se em métodos rápidos e de grande utilidade na fase de avaliação e de prognóstico dos efeitos ambientais de barragens. 


\subsubsection{Abordagem cartográfica}

O método cartográfico permite definir as variações de carga hidráulica no aqüífero adjacente ao reservatório, após o barramento e a montante do corpo da barragem, a partir da superposição de mapas hidrogeológicos temáticos.

O produto final, denominado "Mapa de Potencial de Influência do Enchimento do Reservatório Sobre o Sistema Aqüífero Livre", pode ser definido como o instrumento cartográfico que propicia o zoneamento previsional da distribuição das profundidades do nível d'água subterrânea e corresponde, portanto, a situações finais de amplitude e extensividade dos efeitos induzidos pelo enchimento (ALBUQUERQUE FILHO, 2002).

A carta se refere a situações previsionais e de máxima influência, desconsiderando, assim, o fator tempo. A sua elaboração compreende seguintes passos:

1) confecção do mapa de profundidade natural do nível freático em uma base planialtimétrica;

2) determinações da amplitude de elevação do nível de descarga de base do aqüífero ao longo da futura linha de enchimento; e

3) geração de novas curvas de isoprofundidade do nível freático, alteadas pelos valores equivalentes à elevação do nível de descarga de base do aqüífero livre, ao longo das bordas do reservatório.

O cálculo proposto pode ser simplificado na seguinte equação:

$P_{f}=P+\Delta h$

Sendo,

$P_{f}=$ profundidade final prevista para o nível d'água do aqüífero [L]

$P \quad=$ profundidade do nível d'água do aqüífero antes do enchimento [L]

$\Delta h=$ amplitude da elevação do nível de descarga de base do aqüífero na linha de enchimento do reservatório [L]

Uma vez concluída a previsão dos níveis do aqüífero freático para após o enchimento do reservatório, são definidas as zonas potenciais de influência (QUADRO 
3.1). O mapa é um importante subsídio no planejamento do uso e ocupação de áreas nas bordas do reservatório.

CESTARI JUNIOR \& CELERI (1999) realizaram estudos geotécnicos nas edificações da Cidade de Pereira Barreto (SP), tendo como base a carta de zoneamento de potencial de influência. Os autores observaram concordância entre o zoneamento realizado e os efeitos constatados em campo.

O método de elaboração do mapa de potencial de influência foi aplicado em reservatórios como os de Três Irmãos (SANTOS, 1983), Itaipu (SANTOS, 1984a), Nova Avanhandava (SANTOS, 1984b), Rosana e Taquaruçu (MISTRETTA \& BOTTURA, 1986) e Canoas I e II (ALBUQUERQUE FILHO et al., 1996).

ALBUQUERQUE FILHO (2002) propõe a utilização deste método no processo de Avaliação de Impacto Ambiental (AIA), a partir da etapa de diagnóstico ambiental. $\mathrm{O}$ autor destaca que o método não requer o uso de parâmetros hidráulicos do aqüífero, assim como a utilização de equipamentos sofisticados ou equações matemáticas complexas. Além disso, não existem limitações para o tamanho do reservatório estudado.

No entanto, o referido autor considera apenas a condição de máxima influência do reservatório, em situação de estabilidade final do sistema. Como resultado dos procedimentos adotados no método, as estimativas obtidas tendem a se mostrar conservadoras, notadamente nas porções mais afastadas da borda do reservatório. $A$ imprecisão do método é maior em escalas inferiores a 1:50.000, sendo considerado inadequado nos estudos de detalhamento. 


\begin{tabular}{|c|c|c|c|c|c|c|}
\hline \multirow{3}{*}{$\begin{array}{c}\text { INTERVALO DE } \\
\text { PROFUNDIDADE DO } \\
\text { N.A. MODIFICADO } \\
(\mathbf{m})\end{array}$} & \multirow{3}{*}{$\begin{array}{l}\text { INFLUÊNCIA } \\
\text { POTENCIAL }\end{array}$} & \multirow{3}{*}{$\begin{array}{l}\text { ALTERAÇÕES NO MEIO } \\
\text { FÍSICO (AQÜÍFERO } \\
\text { FREÁTICO) }\end{array}$} & \multicolumn{4}{|c|}{ REPERCUSSÕES MAIS COMUNS NO USO E OCUPAÇÃO DO SOLO } \\
\hline & & & \multicolumn{2}{|c|}{ Áreas Urbanas } & \multicolumn{2}{|r|}{ Zona Rural } \\
\hline & & & Positivas & Negativas & Positivas & Negativas \\
\hline $0-5$ & MÁXIMA & \multirow{3}{*}{$\begin{array}{l}\text { - Afloramento do aqüífero } \\
\text { freático particularmente em } \\
\text { zonas topograficamente } \\
\text { deprimidas } \\
\text { - Aumento da espessura } \\
\text { saturada do aqüífero } \\
\text { - Aporte de volumes de água de } \\
\text { características físico-químicas } \\
\text { diferentes } \\
\text { - Diminuição dos gradientes } \\
\text { hidráulicos subterrâneos } \\
\text { - Aumento da vulnerabilidade à } \\
\text { contaminação } \\
\text { - Colapsos no solo }\end{array}$} & P1 P2 P4 & $\left|\begin{array}{cccc}N 1 & N 3 & N 4 & N 5 \\
\text { N6 } & \text { N7 } & \text { N8 } & \text { N9 } \\
\text { N10 } & \text { N11 }\end{array}\right|$ & $\begin{array}{l}\text { P1 P2 P3 } \\
\text { P4 P5 }\end{array}$ & 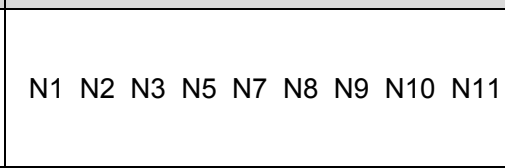 \\
\hline $5-10$ & INTERMEDIÁRIA & & P1 P2 & $\begin{array}{llll}\text { N1 } & \text { N3 } & \text { N7 } & \text { N8 }\end{array}$ & \begin{tabular}{|l|l|} 
P1 P2 P3 & P3 \\
P4
\end{tabular} & N1 N3 N7 N8 \\
\hline$>10$ & MÍNIMA OU NULA & & P1 P2 & N1 & P1 P2 & N1 \\
\hline \multicolumn{5}{|c|}{ Repercussões Negativas (N) } & \multicolumn{2}{|r|}{ Repercussões Positivas (P) } \\
\hline \multicolumn{5}{|c|}{$\begin{array}{l}\text { N1 - Perda de pontos de captação instalados, caso não possuam revestimento } \\
\text { N2 - Perda de produtividade de solos agricultáveis pelo excesso de umidade } \\
\text { N3 - Restrição de usos da água subterrânea pelo aumento de vulnerabilidade à contaminação } \\
\text { N4 - Recalque de fundações e danos em edificações, caso o solo local seja colapsível } \\
\text { N5 - Recalque diferencial em subleito de vias } \\
\text { N6 - Danificação em redes de água, esgoto ou outras tubulações } \\
\text { N7 - Infiltração de água em estruturas subterrâneas } \\
\text { N8 - Afogamento e danificação de estruturas de reservação subterrâneas } \\
\text { N9 - Umidificação ou saturação de covas de cemitério, saponificando cadáveres } \\
\text { N10 - Geração, reativação ou aceleração de processos erosivos lineares (ravinas, boçoracas) } \\
\text { N11 - Instabilização de taludes marginais ao reservatório, em locais suscetíveis ao processo }\end{array}$} & \multicolumn{2}{|c|}{$\begin{array}{l}\text { P1 - Aumento das reservas de águas subterrâneas } \\
\text { P2 - Maior facilidade de acesso aos recursos hídricos } \\
\text { subterrâneos } \\
\text { P3 - Melhoria da umidade subsuperficial dos solos } \\
\text { P4 - Melhoria no desenvolvimento de árvores que } \\
\text { demandam muita água } \\
\text { P5 - Perenização de cursos d'água anteriormente } \\
\text { intermitentes, propiciando aumento da } \\
\text { disponibilidade de águas superficiais }\end{array}$} \\
\hline
\end{tabular}

\section{Fonte: Modificado de ALBUQUERQUE FILHO (2002).}

Quadro 3.1 - Classificação das áreas de acordo com o potencial de influência e efeitos decorrentes em relação à elevação induzida no nível freático. 


\subsubsection{Abordagem numérica}

O método numérico permite, por meio da utilização da modelagem matemática, representar mais realisticamente as complexidades do meio físico.

$\mathrm{Na}$ busca de uma ferramenta que permitisse reproduzir com maior representatividade o meio aqüífero e, também, os processos envolvidos, foram iniciados os estudos de modelagem matemática aplicada à simulação dos fluxos subterrâneos decorrentes da instalação de um reservatório.

No Brasil, os primeiros trabalhos que utilizaram a simulação matemática de fluxos subterrâneos influenciados por reservatórios foram realizados em Presidente Epitácio (SP), na região do reservatório de Porto Primavera. O modelo utilizado foi desenvolvido por PINDER (1970), que efetua resolução numérica por diferenças finitas, da equação diferencial do fluxo bidimensional e transitório, em um meio poroso elástico e heterogêneo. Os resultados obtidos indicaram problemas na calibração do modelo (BOTTURA, 1985).

Em 1985, aplicou-se o modelo bidimensional de TRESCOTT et al. (1976) na mesma área. Esse segundo modelo executa resolução numérica semelhante à de PINDER (op. cit.), mas insere a rotina de evapotranspiração. Não obstante esse fato, os resultados da calibração não foram considerados satisfatórios, indicando a necessidade de novas aferições que possibilitassem melhor reprodução do sistema simulado (MISTRETTA, op. cit.).

Em 1991, iniciou-se a utilização do modelo numérico digital, modular, tridimensional MODFLOW, elaborado por McDONALD \& HARBAUGH (1988), que executa a resolução numérica por diferenças finitas da equação diferencial do fluxo subterrâneo.

As primeiras áreas estudadas a partir dessa nova metodologia foram as cidades de Pereira Barreto (SP), situada à margem do reservatório de Três Irmãos (BOTTURA, 1993), e a do Posto Fiscal XV de Novembro (MS), situada à margem do reservatório de Porto Primavera (BOTTURA, 1994). 
A avaliação dos resultados da modelagem indicou que os principais problemas estavam relacionados à distribuição espacial de valores dos parâmetros hidráulicos utilizados e à determinação da condutância da base do reservatório.

Uma nova fase no desenvolvimento da aplicação de modelos matemáticos para avaliação do impacto hidrogeológico de reservatórios, em escala de detalhe, iniciou-se em 1997, com a sistematização do método proposto (LEITE et al., 1997 e NAKANDAKARE, 1998). Descrevem-se, a seguir, as etapas indicadas para a aplicação de modelos matemáticos na simulação dos fluxos subterrâneos decorrentes do enchimento de reservatórios:

a) Primeira etapa: concepção do modelo hidrogeológico físico para a área de estudo;

b) Segunda etapa: calibração do regime de fluxo em situação prévia ao enchimento do reservatório;

c) Terceira etapa: simulação do enchimento do reservatório a partir dos parâmetros definidos no modelo calibrado. A simulação em regime permanente permite obter as elevações finais do nível d'água, e assim verificar a situação final de equilíbrio; e

d) Quarta etapa: simulação do enchimento do reservatório em regime transitório, permitindo obter as elevações do nível d'água em determinados períodos de tempo após o enchimento.

O método apresenta facilidade de atualização de dados e retroanálises, possibilitando a simulação do impacto em diferentes períodos de tempo após o enchimento do reservatório. No entanto, exige o conhecimento detalhado do sistema aqüífero a ser simulado, assim como dos parâmetros que nele interferem. $O$ sucesso da simulação depende, principalmente, da quantidade e qualidade dessas informações.

De acordo com ALBUQUERQUE FILHO (2002), uma das principais dificuldades na aplicação do método, em escala de bacia de contribuição, é a calibração do modelo matemático de fluxo, considerando-se a diversidade de cada uma das microbacias que compõem a bacia maior. 
Nos últimos anos, diversos autores têm utilizado o Sistema de Informação Geográfica para auxiliar no desenvolvimento de estudos de modelagem matemática de fluxos em escala regional. O método, também tem apresentado resultados satisfatórios em diferentes estudos de previsão.

Dentre eles, pode ser destacado o trabalho realizado por TANG \& KONDOH (1996), que utilizaram o SIG IDRISI associado ao programa MODFLOW, na região de Ichihara (Japão), para estudar a influência, no sistema hidrogeológico regional, de mudanças ocasionadas no meio ambiente. Nesse estudo, as informações do modelo conceitual foram transferidas para o SIG e deste para o MODFLOW. Durante a calibração, os parâmetros foram modificados no SIG, e posteriormente transferidos para o MODFLOW. O processo foi repetido sucessivamente até a calibração do modelo e para a simulação dos diferentes cenários. Os autores concluíram que o processo facilitava a calibração, preservando as vantagens individuais dos programas.

No mesmo ano, WATKINS et al. (1996) destacaram o SIG como uma ferramenta importante na sistematização dos parâmetros a serem utilizados no modelo, para a geração de dados estatisticamente espacializados e por significar maior facilidade de visualização das informações. Os autores avaliaram diferentes formas de integração entre a modelagem matemática e o SIG, destacando a utilidade do SIG no contexto dos sistemas que dão suporte à de tomada de decisão.

Em outro estudo, realizado por WARZOCHA \& REEVE (1998), foi utilizado o SIG Maplnfo para coletar e organizar as informações do modelo hidrogeológico conceitual da região do lago Agassiz (Minesota, USA). O modelo, representando uma área de $1.800 \mathrm{~km}^{2}$, foi calibrado em fluxo estacionário, utilizando-se o programa MODFLOW e, posteriormente, submetido a simulações de mudanças climáticas. De acordo com os autores, o procedimento permitiu a entrada de informações georeferenciadas no modelo matemático e facilitou a representação gráfica dos resultados das simulações.

Mais recentemente, TSOU \& WHITTEMORE (2001) destacam a importância do SIG como uma plataforma de integração que permite compilar, organizar e analisar dados, facilitando a calibração do modelo, a apresentação dos resultados e o seu processamento final. Os autores destacam o trabalho realizado no sudoeste de Kansas (USA), no qual foi utilizada a extensão 3D Analyst do programa ArcView, como interface para transferir as informações do modelo conceitual para o programa MODFLOW. Nesse trabalho, os autores ressaltam a eficiência do pré e pós- 
processamento dos dados, assim como a importância da utilização dessa ferramenta na calibração do modelo, realizada por meio do programa PEST.

Os resultados desses trabalhos destacam a importância da utilização do SIG associado aos modelos matemáticos de fluxo, como uma valiosa parceria na previsão de eventos futuros e na gestão dos recursos hídricos subterrâneos em escala regional. 


\section{A ÁREA DE ESTUDO}

A escolha da área piloto para o desenvolvimento desta pesquisa decorreu, principalmente, dos seguintes fatores:

a) possibilidade de se trabalhar com a bacia hidrográfica de contribuição do reservatório, da barragem até o remanso; e

b) possibilidade de se desenvolver o trabalho de acordo com a necessidade da pesquisa.

Assim sendo, foi escolhida como área piloto para o desenvolvimento da pesquisa, a bacia de drenagem compreendida pelo médio e alto curso do rio BiritibaMirim, a qual será a área de contribuição do reservatório da barragem de mesmo nome.

A barragem de Biritiba-Mirim é uma das obras integrantes do Sistema Produtor Alto Tietê (SPAT), que é um sistema integrado de obras hidráulicas já parcialmente implantado.

O SPAT, que soma ao todo $1.196 \mathrm{~km}^{2}$, faz parte da Área de Proteção de Mananciais da Região Metropolitana de São Paulo (RMSP), e engloba as cabeceiras do rio Tietê e seus afluentes, sendo, por isso, objeto de severas restrições ao uso e ocupação do solo (CCN PLANEJAMENTO E ENGENHARIA S/C LTDA, 1997).

Atualmente, fazem parte integrante do SPAT as seguintes unidades: Barragem de Ponte Nova, Barragem de Taiaçupeba, Barragem de Jundiaí, Canal de interligação Jundiaí/Taiaçupeba, Barragem de Biritiba-Mirim, Barragem de Paraitinga, Sistema de Interligação Tietê/Biritiba e Biritiba/Jundiaí e Dique Provisório de Biritiba, sendo que as quatro primeiras obras já se encontram implantadas (FIGURA 4.1). 


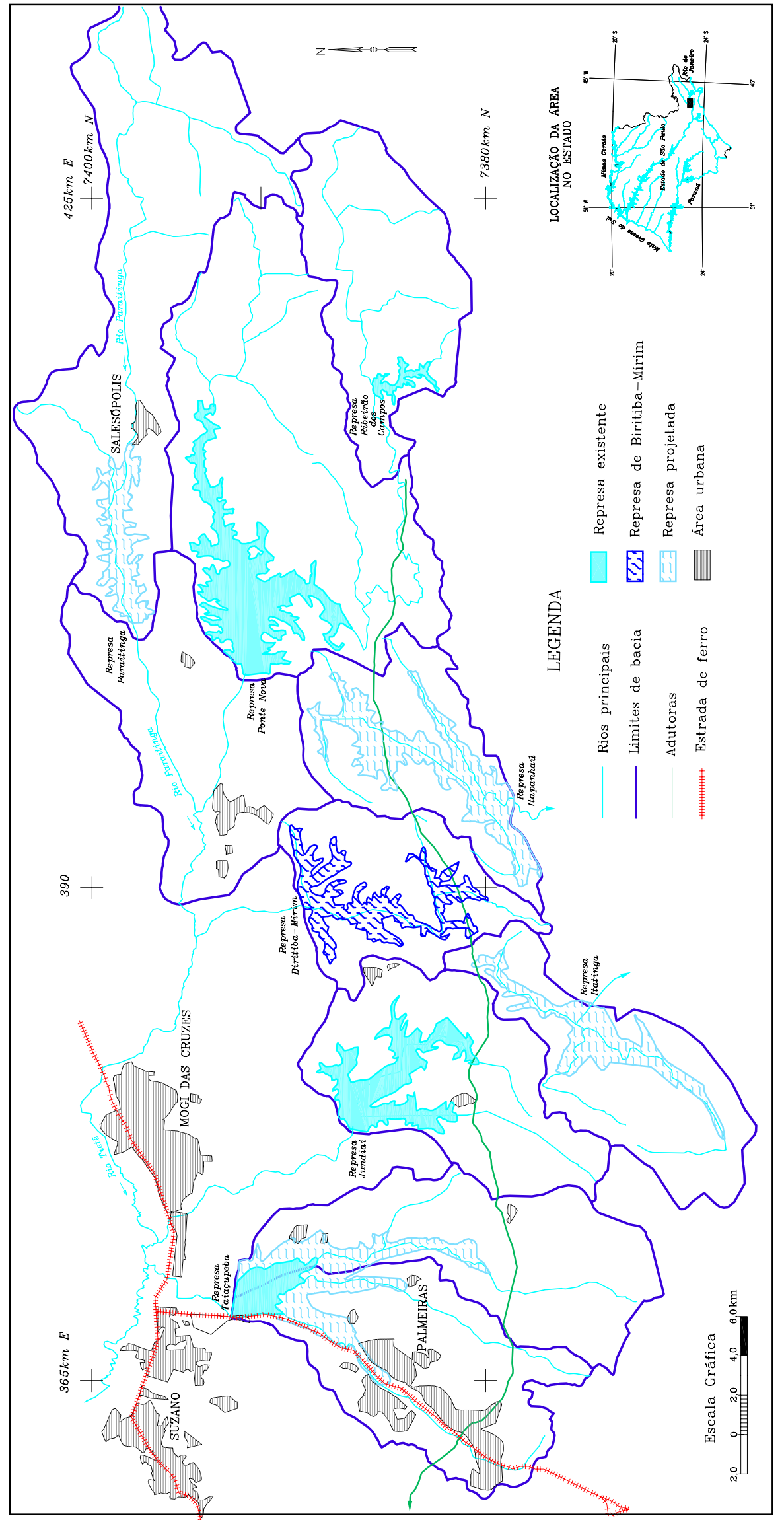

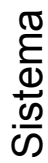

응

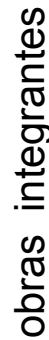

$\frac{\pi}{0}$

$+$

艺

옴

亮

$\frac{1}{0}$

हิ

전

过

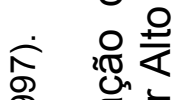

颀

능

은

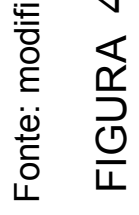




\subsection{Localização}

A área estudada situa-se no extremo leste da bacia do alto curso do rio Tietê, entre as coordenadas UTM aproximadas $7.380 \mathrm{~km} \mathrm{~N}$ e $7.400 \mathrm{~km} \mathrm{~N}$, e $380 \mathrm{~km}$ E e 420 km E; encontra-se inserida na RMSP e abrange áreas dos municípios de Biritiba-Mirim e Mogi das Cruzes.

O reservatório de Biritiba-Mirim está localizado no rio Biritiba-Mirim, que é afluente da margem esquerda do rio Tietê e constitui divisa entre os municípios de Mogi das Cruzes e Biritiba-Mirim, compondo uma bacia de drenagem de aproximadamente $75 \mathrm{Km}^{2}$. 


\section{METODOLOGIA}

A presente Pesquisa foi orientada considerando-se a proposta de roteiro metodológico indicado por ALBUQUERQUE FILHO (2002), para estudos de previsão e análise da elevação induzida no nível freático, em decorrência do enchimento de reservatórios hidrelétricos. Deste modo, este trabalho corresponde à fase de Caracterização Geral do Reservatório, de acordo com o referido autor, e propõe a utilização de Sistema de Informação Geográfica (SIG) associado à modelagem matemática como principal método de previsão.

O modelo é um instrumento que busca representar a realidade observada em campo. No caso da representação de um modelo hidrogeológico, o modelo matemático permite simular o fluxo de águas subterrâneas de forma indireta, por meio de equações que expressam os processos físicos que ocorrem no sistema. Modelos de fluxos de águas subterrâneas têm por objetivo obter a distribuição das cargas hidráulicas do aqüífero.

Com o objetivo de obter um modelo matemático que represente adequadamente a área e a problemática estudada, o processo de modelagem foi orientado de acordo com o roteiro metodológico modificado de ANDERSON \& WOESSNER (1992), conforme descrito a seguir:

1) definição da proposta: identificação clara do problema a ser estudado, o que implicará na determinação do programa de computador que deverá ser utilizado;

2) desenvolvimento de um modelo conceitual: identificação das unidades hidrogeológicas e contornos do sistema. Além de informações sobre balanço hídrico e dados de campo, necessários para a definição de estresses hidrológicos e dos parâmetros de entrada do modelo;

3) seleção do programa de computador: escolha do programa que contenha o algoritmo adequado para resolver de forma numérica o modelo matemático;

4) elaboração do modelo matemático: adaptação do modelo conceitual, de forma que possa ser interpretado pelo programa de modelagem. Envolve a definição das condições de contorno e a seleção preliminar de valores que 
representem os parâmetros do aqüífero e estresses hidrológicos, além da definição da malha;

5) calibração: reprodução, mediante $o$ desenvolvimento de um modelo matemático, das condições hidrogeológicas observadas em campo;

6) verificação do modelo: verificação da confiabilidade do modelo, utilizando um conjunto de parâmetros previamente calibrados, para reproduzir um segundo conjunto de dados de campo; e

7) PREVISÃO: quantificação da resposta do sistema modelado a futuros eventos.

A proposta de ANDERSON \& WOESSNER (1992) foi adaptada para atender às necessidades do presente estudo, conforme ilustra a FIGURA 5.1.

Uma vez definida a proposta do trabalho, ou seja, a utilização da modelagem matemática com fins previsionais, procedeu-se à coleta de dados bibliográficos e de campo, que possibilitassem a elaboração do modelo conceitual da área de estudo.

A pesquisa bibliográfica sobre a área de estudo incluiu a aquisição de cartas planialtimétricas em escala 1:10.000. Essas informações permitiram a caracterização geral da área e a elaboração da base cartográfica. A seguir, foram realizados os trabalhos de campo, para detalhamento, que envolveram o cadastro de captações de água subterrânea e de nascentes, e a execução de sondagens, para complementar as informações sobre o aqüífero, nas áreas de interesse.

A análise dos dados coletados permitiu a elaboração do modelo conceitual da área, no qual foram definidas as unidades hidrogeológicas, o sistema de fluxo e realizado o balanço hídrico.

Uma vez elaborado o modelo conceitual, foi selecionado o programa adequado para realizar a modelagem matemática de fluxos subterrâneos da bacia. O modelo conceitual foi inicialmente projetado em SIG, por meio do módulo MAP da interface Groundwater Modeling System - GMS (Engineering Computer Graphics Laboratory ECGL, 1996). 
ROTEIRO METODOLÓGICO

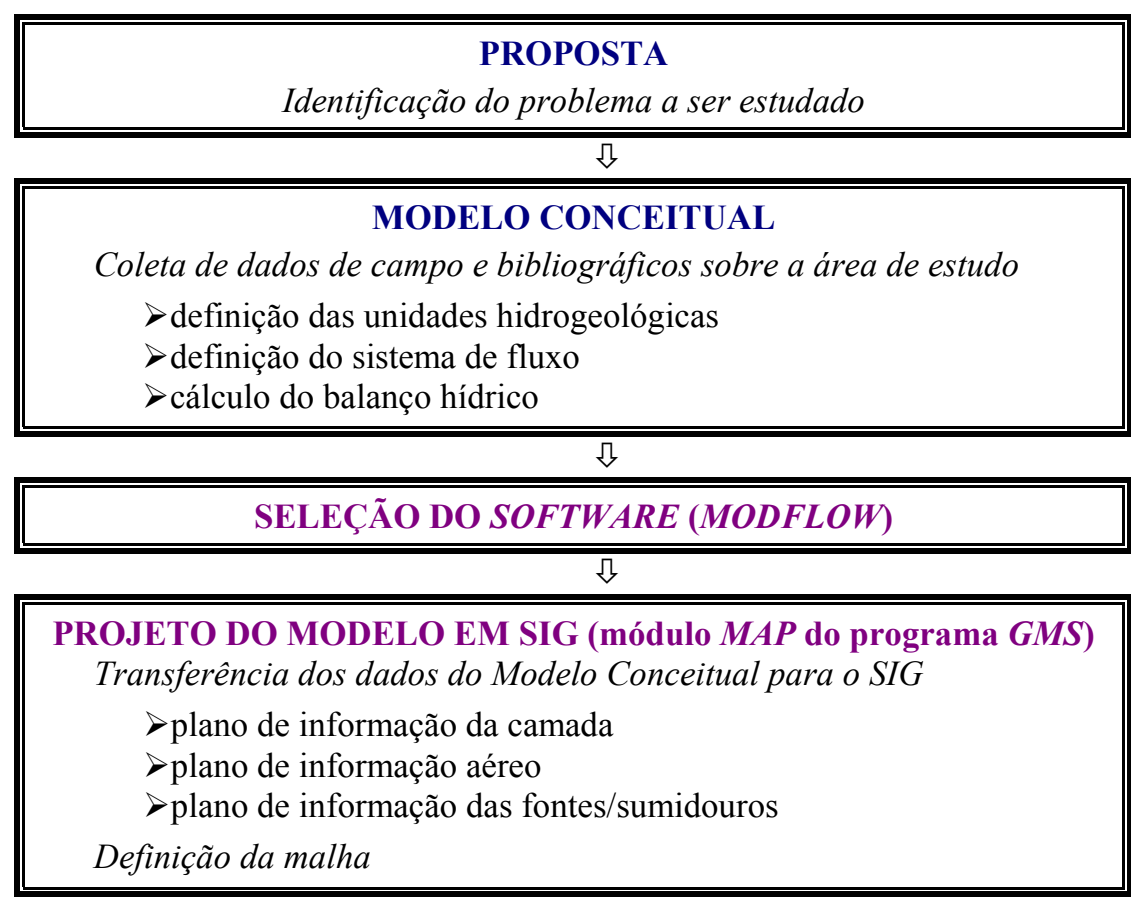

$\sqrt{3}$

CALIBRAÇÃO DO MODELO MATEMÁTICO (módulo MODFLOW do programa GMS)

Transferência dos dados do SIG para o MODFLOW

Reprodução das condições hidrogeológicas observadas em campo

ת

$1^{a}$ SIMULAÇÃO DO ENCHIMENTO DO RESERVATÓRIO

Inserção do reservatório em SIG, no modelo calibrado, e transferência dos parâmetros para o MODFLOW

$>$ instalação de poços de monitoramento

$\sqrt{3}$

\section{VERIFICAÇÃO DO MODELO}

Utilização dos parâmetros calibrados para reproduzir um segundo conjunto de dados de campo

$>$ monitoramento de poços

$>$ execução de ensaios hidrogeológicos complementares

\

$2^{\text {a }}$ SIMULAÇÃO DO ENCHIMENTO DO RESERVATÓRIO

Inserção do reservatório em SIG, no modelo verificado, e transferência dos parâmetros para o MODFLOW

$\sqrt{3}$

ELABORAÇÃO DO MAPA PREVISIONAL DE INFLUÊNCIA

Delimitação das zonas de influência do reservatório sob o aqüifero livre

ת

DEFINIÇÃO DO PROGRAMA DE MONITORAMENTO DO AQÜÍFERO LIVRE

Definição do periodo e periodicidade de monitoramento após o enchimento do reservatório

FIGURA 5.1 - Roteiro metodológico utilizado na realização da pesquisa 
O modelo matemático, inicialmente projetado em SIG, foi transferido para o programa MODFLOW, da interface GMS (ECGL, 1996). Realizou-se, então, a calibração e posteriormente, a simulação do enchimento do reservatório. Os trabalhos resultaram na elaboração do mapa potenciométrico calibrado e do mapa potenciométrico resultante da simulação do enchimento do lago, na escala 1:25.000, com destaque para as áreas onde o nível da água subterrânea sofrerá maior influência do reservatório.

Foram, então, identificados os locais para perfuração de poços de monitoramento e executada a sua instalação. O dados do monitoramento dos poços cadastrados e poços instalados na bacia e a execução de ensaios hidrogeológicos permitiram a verificação do modelo.

Com os parâmetros resultantes do modelo verificado, realizou-se uma segunda simulação do enchimento do reservatório, a partir da qual foi elaborado o Mapa Previsional de Influência do reservatório sobre o aqüífero livre (mapa com delimitação de zonas de isoprofundidades), e definido o programa de monitoramento adequado para a bacia.

Descrevem-se a seguir, de forma detalhada, cada um dos tópicos citados.

\subsection{Coleta básica de dados}

Esta primeira fase do estudo envolveu o levantamento das informações existentes e a execução dos trabalhos preliminares de campo.

\subsubsection{Pesquisa bibliográfica}

A pesquisa contou com o levantamento das seguintes informações básicas: caracterização geral da área, geologia, geomorfologia, hidrogeologia, climatologia e uso e ocupação do solo.

Em relação à apresentação dos diferentes produtos cartográficos, a base planialtimétrica constou de uma única prancha, na escala 1:25.000, elaborada a partir de digitalização, utilizando-se o software AutoCAD (versão 2000) (AUTODESK, 1999). 
Foi utilizada a planta base obtida das folhas topográficas Pico do Garrafão (SF-23-Y-DIV-2-SE-B), Fazenda Vanguarda (SF-23-Y-D-IV-2-NE-F), Parque Bela Vista (SF-23-YD-IV-2-SE-D), Sogo (SF-23-Y-D-IV-2-SE-A), Cruz do Alto (SF-23-Y-D-IV-2-NE-E) e Biritiba Açu (SF-23-Y-D-IV-2-SO-B) (EMPLASA, 1982, 1988 e 1996), dos municípios de Biritiba-Mirim e Mogi das Cruzes, existentes na escala 1:10.000.

\subsubsection{Atividades preliminares de campo}

Os trabalhos de campo foram desenvolvidos no período de novembro e dezembro de 1999. Descrevem-se, a seguir, as atividades realizadas.

\subsubsection{Cadastramento de captações de águas subterrâneas e nascentes}

Os trabalhos de campo compreenderam visitas de reconhecimento regional, quando foram registrados tipos de uso e ocupação do solo relevantes para os objetivos do estudo e foram cadastradas captações de água subterrânea e nascentes na área de estudo.

As visitas a pontos d'água subterrânea envolveram medições de nível d'água, condutividade elétrica (com equipamento portátil Digimed modelo CD-2P), pH (utilizando medidor Digimed) e temperatura do ar e da água (utilizando termômetro comum). Em cada local visitado foi também registrada, quando pertinente, a ocorrência de fossas negras e secas (privadas), suas características construtivas e posição topográfica em relação aos poços.

Foram cadastrados e plotados em mapa 64 (sessenta e quatro) poços tipo cacimba e 01 (um) poço tubular, além de terem sido registradas 20 nascentes. A localização destes pontos foi obtida por meio da utilização de GPS portátil marca GARMIN, modelo 45.

\subsubsection{Execução de sondagens a trado}

Foram executadas 21 (vinte e uma) sondagens a trado, com diâmetro de 4", utilizando trado motorizado HONDA GX120. O trabalho teve como objetivo a obtenção da profundidade do nível d'água subterrânea, de maneira a complementar as informações adquiridas com o cadastro dos poços e nascentes. 
Em cada local perfurado, foram registradas as seguintes informações: profundidade final do furo, profundidade do nível d'água e descrição litológica do material atravessado. A localização dos pontos foi realizada por meio de GPS portátil marca GARMIN, modelo 45.

\subsection{Concepção e elaboração do modelo matemático}

Atualmente, a modelagem matemática constitui uma ferramenta fundamental para o melhor entendimento da dinâmica dos sistemas hidrogeológicos e na previsão de distintos cenários futuros.

Os procedimentos ou passos efetuados no computador para resolução das equações utilizadas para constituir o modelo matemático formam o programa de computador. Esse programa, construído para resolver as equações parciais por meio de algoritmos numéricos, foi denominado por HIRATA (1994) e CLEARY (1989) simplesmente de modelo.

Neste trabalho, foi utilizado o termo modelo matemático para a representação matemática de um determinado sistema físico de água subterrânea e o termo programa para referir-se ao software utilizado para a construção do modelo matemático, como expresso em IRITANI (1998).

O modelo matemático de fluxo subterrâneo é aplicado a partir da definição de um modelo hidrogeológico para a área em estudo. Quanto melhor a qualidade dos dados de entrada e a compreensão do modelo conceitual do sistema, melhores serão os resultados da modelagem matemática. Os procedimentos metodológicos adotados no estabelecimento desse modelo matemático encontram-se descritos a seguir.

\subsubsection{Modelo conceitual}

O objetivo da elaboração de um modelo conceitual é o de simplificar o problema real apresentado e organizar os dados existentes, obtendo-se uma melhor interpretação do funcionamento do sistema, facilitando a sua análise. No entanto, esta simplificação deve ser fiel à complexidade do sistema em análise, de modo que torne válida a representação das condições hidrogeológicas (ANDERSON \& WOESSNER, 1992). 
O modelo conceitual permite a definição do domínio do modelo, do tipo de aqüífero a ser modelado, das condições iniciais e de contorno, e das entradas e saídas de água do sistema.

A elaboração do modelo conceitual foi realizada com base em pesquisa bibliográfica, dados obtidos durante $\mathrm{o}$ cadastramento de captações de água subterrânea e nascentes, assim como a partir da execução de sondagens a trado.

A partir do estudo de informações geológicas, geomorfológicas, climatológicas e hidrogeológicas da bacia de Biritiba-Mirim, foi elaborado o modelo conceitual da área de interesse. A análise dessas informações permitiu:

1) a caracterização das unidades hidrogeológicas;

2) a definição do sistema de fluxo subterrâneo e delimitação do contorno da bacia de contribuição do reservatório estudado, que se encontra representada no mapa potenciométrico preliminar, obtido a partir de:

a) cotas de nascentes e rios (informações obtidas nas cartas topográficas e complementadas por dados de campo);

b) dados de nível d'água, obtidos das sondagens e dos poços cadastrados em campo; e

3) a preparação do balanço hídrico para a bacia de interesse.

\subsubsection{Definição do modelo matemático}

Um modelo matemático é representado pelas equações que governam o sistema (no caso do presente estudo, a equação fundamental de fluxo de água subterrânea), assim como pelas condições iniciais e de contorno.

\subsubsection{Equação de fluxo da água subterrânea}

ANDERSON \& WOESSNER (1992) descrevem dois enfoques conceituais sobre os sistemas de águas subterrâneas: do ponto de vista do aqüífero e do ponto de vista do fluxo. 
O estudo do sistema do ponto de vista do aqüífero tem como base o conceito de aqüífero confinado, semi-confinado e livre. O aqüífero semi-confinado possui como limite superior uma camada semi-confinante, sobre a qual se encontra o aqüífero livre, que, por sua vez, tem como limite superior o seu nível de água. Sob esse ponto de vista, o fluxo de água subterrânea é considerado horizontal nos aqüíferos e vertical através da camada semi-confinante. A condutividade hidráulica é associada à dimensão vertical, no intuito de obter valores médios do coeficiente de transmissividade do aqüífero. Esse parâmetro é expresso pelo produto entre a condutividade hidráulica e a espessura saturada do aqüífero.

O estudo do sistema do ponto de vista do aqüífero é utilizado para simular sistemas bidimensionais ou quase-tridimensionais de fluxo, de aqüíferos livres, confinados e semi-confinados. A carga hidráulica da camada semi-confinante não é calculada durante a simulação. Esta abordagem permite a utilização de modelos de uma única camada nos casos em que a simulação ocorre em fluxo permanente e o aqüífero livre não é afetado pela variação da carga hidráulica do aqüífero confinado.

O estudo do sistema do ponto de vista do fluxo deve apresentar, por sua vez, pelo menos três camadas: a do aqüífero livre, a da camada semi-confinante e a do aqüífero confinado. As cargas hidráulicas são então calculadas para cada uma delas.

O estudo do sistema do ponto de vista do fluxo permite considerar os componentes horizontal e vertical de fluxo através do sistema. A equação aplicada ao modelo matemático que governa o fluxo da água subterrânea, considerando-se um meio heterogêneo e anisotrópico, é obtida pela combinação matemática da equação de balanço de água e da lei de Darcy (ANDERSON \& WOESSNER, 1992 e CLEARY, 1989).

A equação fundamental assim obtida é representada na Equação 5.1.

$$
\frac{\partial}{\partial x}\left(K_{x} \frac{\partial h}{\partial x}\right)+\frac{\partial}{\partial y}\left(K_{y} \frac{\partial h}{\partial y}\right)+\frac{\partial}{\partial z}\left(K_{z} \frac{\partial h}{\partial z}\right)+R *(x, y, z, t)=S_{s} \frac{\partial h}{\partial t}
$$

Sendo,

$h$ = carga hidráulica [L]

$K_{x}, K_{y}$ e $K_{z}$ são valores de condutividade hidráulica ao longo dos eixos $x, y$ e $z$, respectivamente $[\mathrm{L} / \mathrm{T}]$ 
$S_{s}=$ armazenamento específico [1/L]. Utilizado em equações tridimensionais. Equivalente ao volume de água liberado $\left[L^{3}\right]$, por unidade de volume de material poroso $\left[\mathrm{L}^{3}\right]$, por unidade de decréscimo da carga hidráulica $[\mathrm{L}]$.

$t \quad=$ tempo $[\mathrm{T}]$

$R^{*}(x, y, z, t)=$ termo que representa as fontes/sumidouros de água. Intrinsecamente positivo, define o volume de água que entra no sistema por unidade de volume de aqüifero por unidade de tempo. Para simular saída de água do sistema $R^{*}=-W^{*}\left[\mathrm{~L}^{3} / \mathrm{TL}^{3}\right]$.

ANDERSON \& WOESSNER (1992) demonstram como a equação fundamental de fluxo de água subterrânea foi derivada a partir da combinação do balanço de água $e$ da lei de Darcy. A derivação inicia-se a partir de um cubo de material poroso, suficientemente grande para representar as propriedades do meio poroso, mas suficientemente pequeno para não refletir grande mudanças na carga hidráulica. $O$ cubo, de volume igual a $\Delta x \Delta y \Delta z$ (FIGURA 5.2), é conhecido como volume elementar representativo de um aqüífero. $O$ fluxo através do cubo é expresso em termos de volume de descarga $(\boldsymbol{q})$, que se refere a um vetor que pode ser expresso em termos de três componentes:

$$
\boldsymbol{q}=q_{x} \boldsymbol{i}_{x}+q_{y} \boldsymbol{i}_{y}+q_{z} \boldsymbol{i}_{z}
$$

De acordo com a equação do balanço de água:

fluxo de saída $\left(q_{\text {saida }}\right)$ - fluxo de entrada $\left(q_{\text {entrada }}\right)=$ variação no armazenamento 


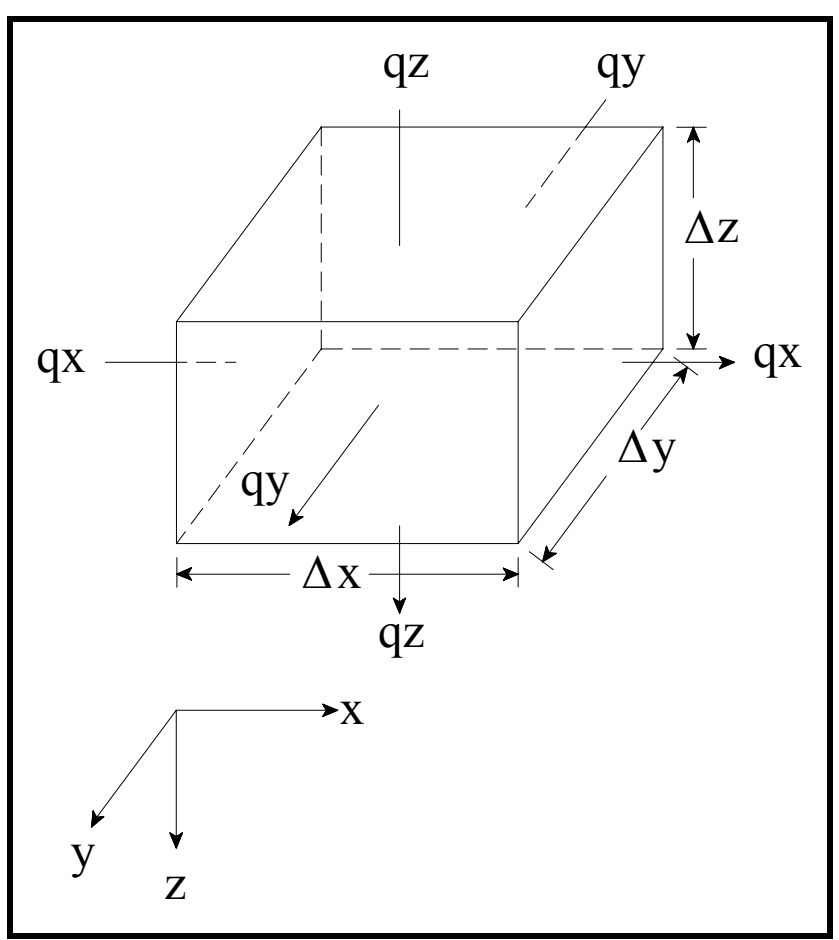

Fonte: FETTER (1994).

FIGURA 5.2 - Representação do volume elementar de um aqüífero

Considerando-se os fluxos de entrada e saída nos três eixos de coordenadas e as fontes e sumidouros do sistema $\left(R^{*}\right)$, tem-se:

$$
\begin{aligned}
& \left(\frac{\partial q_{x}}{\partial x}+\frac{\partial q_{y}}{\partial y}+\frac{\partial q_{z}}{\partial z}-R^{*}\right) \Delta x \Delta y \Delta z=\text { variação no armazenamento } \\
& R^{*}=\text { fonte }
\end{aligned}
$$

A variação no armazenamento é representada pelo armazenamento específico $\left(S_{S}\right)$, sendo igual ao volume de água $(V)$ liberado do armazenamento por unidade de volume do aqüífero por unidade de variação da carga hidráulica (h) (Equação 5.4).

$$
S_{s}=-\frac{\Delta V}{\Delta h \Delta x \Delta y \Delta z}
$$

Sendo: 
$S_{s}=$ armazenamento específico [1/L]. Utilizado em equações tridimensionais.

$\Delta V=$ volume de água liberado $\left[\mathrm{L}^{3}\right]$

$\Delta h=$ unidade de decréscimo da carga hidráulica [L]

$\Delta x \Delta y \Delta z=$ volume de material poroso $\left[\mathrm{L}^{3}\right]$

A variação do armazenamento no tempo é expresso através da Equação 5.7.

$$
\frac{\Delta V}{\Delta t}=-S_{s} \frac{\partial h}{\partial t} \Delta x \Delta y \Delta z
$$

Tem-se, então:

$$
\frac{\partial q_{x}}{\partial x}+\frac{\partial q_{y}}{\partial y}+\frac{\partial q_{z}}{\partial z}=-S_{s} \frac{\partial h}{\partial t}+R^{*}
$$

Pela lei de Darcy:

$$
\begin{aligned}
& q_{x}=-K_{x} \frac{\partial h}{\partial x} \\
& q_{y}=-K_{y} \frac{\partial h}{\partial y} \\
& q_{z}=-K_{z} \frac{\partial h}{\partial z}
\end{aligned}
$$

Combinando-se a lei de Darcy (Eq.5.7) com a equação de balanço de água (Eq.5.6), é obtida a equação fundamental de fluxo de água subterrânea. A Equação 5.8 é derivada da 5.1, definindo-se $\partial \mathrm{h} / \partial \mathrm{z}$ igual a zero, adicionando o termo de drenança e estabelecendo $b S_{s}=S$ e $b R^{*}=R$, onde $b$ [L] é a espessura da camada aqüifera.

Assim, o sistema do ponto de vista do aqüífero pode ser representado pela Equação fundamental 5.8 (ANDERSON \& WOESSNER, 1992):

$$
\frac{\partial}{\partial x}\left(T_{x} \frac{\partial h}{\partial x}\right)+\frac{\partial}{\partial y}\left(T_{y} \frac{\partial h}{\partial y}\right)=S \frac{\partial h}{\partial t}-R+L
$$


Sendo:

$h$ = carga hidráulica [L]

$T_{x}$ e $T_{y}=$ transmissividade ao longo dos eixos $x$ e $y\left[\mathrm{~L}^{2} / \mathrm{T}\right]$

$S=$ coeficiente de armazenamento [adimensional]. Utilizado em simulações bidimensionais.

$R$ = termo de fontes/sumidouros de água. Intrinsecamente positivo, para saída de água do sistema $R=-W$, onde $W$ é o volume de água que sai $[\mathrm{L} / \mathrm{T}]$.

$\mathrm{E}:$

$L=-K_{z}^{\prime} \frac{h_{\text {origem }}-h}{b^{\prime}}$

$L=$ drenança pela camada confinante $[\mathrm{L} / \mathrm{T}]$

$K_{z}^{\prime}=$ condutividade hidráulica vertical [L/T]

$b^{\prime}=$ espessura da camada confinante [L]

$h_{\text {origem }}=$ carga hidráulica no reservatório de origem [L]

$h$ = carga hidráulica [L]

O termo do lado esquerdo da equação representa o fluxo horizontal através do aqüífero. A utilização de $T_{x}$ e $T_{y}$ em derivadas parciais permite variar espacialmente o parâmetro transmissividade (considerando a heterogeneidade do sistema), enquanto que a indicação de $x$ e $y$ permite representar as possíveis variações da transmissividade nessas direções (no caso de meio anisotrópico).

A equação pode ser aplicada no caso de aqüíferos livres, utilizando as hipóteses de Dupuit (CUSTÓDIO \& LLAMAS, 1996):

1) linhas de fluxo horizontais e equipotenciais verticais; $e$

2) gradiente hidráulico horizontal igual à inclinação da superfície livre e invariável com a profundidade.

Para aqüíferos livres é utilizado:

$T_{x}=K_{x} b$ e $T_{y}=K_{y} b$ 
Sendo $b$ [L] a espessura saturada do aqüífero, determinada pelo seu nível de água. A componente de transmissividade na direção $z$ é desconsiderada no caso de modelos bidimensionais, que são utilizados para descrever fluxos horizontais.

No presente estudo, foi considerado um sistema bidimensional, heterogêneo e isotrópico, com os eixos do sistema de coordenadas coincidentes com o tensor de condutividade hidráulica.

\subsubsection{Condições iniciais}

A condição inicial refere-se à distribuição da carga hidráulica no domínio do modelo matemático, no início da simulação (tempo igual a zero).

\subsubsection{Condições de contorno}

As condições de contorno são aproximações matemáticas que representam as fronteiras hidráulicas ou físicas que delimitam o modelo, ou seja, especificam a carga hidráulica ou o fluxo, nos limites do sistema. Nas simulações em condição de fluxo permanente, são principalmente as condições de contorno que determinam os padrões de fluxo. No caso de fluxo transitório, a influência das condições de contorno ocorre principalmente quando o efeito transitório do estresse atinge esse limite.

De acordo com ANDERSON \& WOESSNER (1992), distinguem-se dois tipos de limites: físicos, formados, por exemplo, pela presença física de rocha impermeável ou por um grande corpo de água, como lagos, lagunas ou rios; e hidráulicos, que são limites invisíveis, como no caso dos divisores de água subterrânea e córregos.

Estas condições de contorno são matematicamente classificadas em três tipos:

1) limites com carga hidráulica específica (condição Direchlet), nos quais o nível é especificado. A carga pode ser constante, como por exemplo um lago, ou variar em função do tempo e do espaço, como nos rios (CLEARY, 1989);

2) limites com fluxo específico (condição Neumann), nos quais o fluxo que ocorre através do corpo é dado. Exemplifica-se aqui o fluxo nulo para divisores de água subterrânea, sendo a recarga, especificada para a primeira camada do modelo; e 
3) limites com o fluxo dependente da carga hidráulica (condição Cauchy ou limite misto), nos quais o fluxo é calculado com base na diferença entre a carga hidráulica especificada e a carga hidráulica calculada pelo modelo. Este tipo de condição de contorno é utilizado para definir a drenança de um corpo de água superficial.

\subsubsection{Programa utilizado}

O conjunto de rotinas utilizadas para resolver o modelo matemático no computador compõe o programa de computador. O programa de computador soluciona o conjunto de equações algébricas, sendo genérico, ou seja, independe das condições de contorno e iniciais, da malha, e parâmetros especificados para cada área.

Neste trabalho, foi utilizado como modelo matemático, para a representação de um determinado sistema físico de água subterrânea, o programa tridimensional modular MODFLOW, elaborado por McDONALD \& HARBAUGH (1988), que contém o algarismo utilizado para resolver o modelo matemático de forma numérica. $O$ método numérico utilizado é o de diferenças finitas, que é uma representação discretizada em um ponto, ou seja, a carga hidráulica é definida nos nós da malha (CLEARY, 1989). No presente estudo, foram definidos parâmetros para os nós centrais da malha, sendo os valores extrapolados para a respectiva área de cada célula. A malha do modelo é definida por linhas e colunas.

O sistema de equações de diferenças finitas é resolvido pelo método de iterações sucessivas, que calcula os fluxos célula a célula.

O programa apresenta-se na forma modular, com os efeitos dos vários parâmetros (tais como rios, poços, recargas, dentre outros), sobre o aqüífero, sendo simulados como sub-rotinas do programa principal.

O modelo apresenta, como resultados, a distribuição das cargas hidráulicas e dos rebaixamentos ou elevações em cada célula, além dos cálculos de balanço de massa geral e de fluxo nas interfaces do aqüifero com rios, lagos e drenos. 


\subsubsection{Projeto do modelo no SIG}

Uma vez selecionado o modelo matemático, as informações do modelo conceitual foram transferidas para o módulo MAP, da interface Groundwater Modeling System - GMS elaborado pelo Engineering Computer Graphics Laboratory - ECGL (ECGL, 1996), que permite transcrever o modelo conceitual para o SIG, mediante a criação dos seguintes planos de informação (coverage): atributos aéreos, fontes/sumidouros locais e atributos das camadas.

Os atributos aéreos incluem os dados de recarga e evapotranspiração; fontes/sumidouros abrangem os dados de entradas e saídas de água do aqüífero, devido a entidades como córregos, rios e poços (de bombeamento e/ou injeção); e os atributos das camadas referem-se às características hidrogeológicas do sistema aqüífero (transmissividade, porosidade, armazenamento, dentre outros).

Após concluir a transferência dos dados para o SIG, foi definida a malha do modelo, mediante o módulo GRID da inteface GMS (ECGL, 1996). Este módulo permite recortar a malha no contorno da área de interesse, previamente definida no módulo MAP, e considera ativas apenas as células internas.

Uma vez concluído o projeto do modelo em SIG e definida a malha, as informações foram transferidas para o modelo matemático MODFLOW.

\subsubsection{Calibração do modelo matemático}

A calibração de um modelo matemático de fluxo implica a obtenção, em laboratório, das condições em que as cargas hidráulicas e fluxos subterrâneos resultantes sejam correlacionáveis às situações ocorrentes na natureza, em escala real. Com este objetivo, são designados parâmetros que aproximem o modelo matemático do real.

Assim sendo, a calibração foi efetuada em regime de fluxo permanente, o qual foi definido a partir dos dados disponíveis. Nesta etapa, foram avaliadas a influência e consistência dos parâmetros de entrada do modelo.

Foi realizada a concepção e calibração preliminar do modelo matemático para as condições atuais da bacia de drenagem do rio Biritiba-Mirim. 
Os dados de nível de água e informações dos poços, cadastrados em novembro e dezembro de 1999, foram utilizados para a elaboração do mapa potenciométrico na condição de calibração inicial. Esse mapa permitiu avaliar o desempenho do modelo calibrado.

Os valores de permeabilidade, recarga e evapotranspiração foram avaliados na calibração, de forma a se obter o melhor ajuste às condições potenciométricas iniciais.

\subsubsection{Primeira simulação do enchimento do reservatório}

A configuração das cargas potenciométricas resultantes da calibração foi adotada como condição inicial para efeitos de simulação. Também foram mantidos constantes os parâmetros do aqüífero resultantes do modelo já calibrado.

Na simulação, admitiu-se, em caráter conservador, o enchimento instantâneo do reservatório de Biritiba-Mirim à cota máxima de 757,5 m, com o objetivo de caracterizar os possíveis reflexos induzidos sobre o nível freático.

Foi executada a simulação em condições de regime de fluxo permanente, controlado por meio de cargas constantes no centro das células sobre sua influência, com o objetivo de verificar a situação final de equilíbrio.

A partir da superposição do mapa potenciométrico inicial (resultante da calibração) e do mapa potenciométrico final (resultante da simulação do enchimento do reservatório), foi possível destacar as zonas de maior influência do reservatório nos níveis de água subterrânea.

\subsubsection{Instalação de poços de monitoramento}

A partir da definição das áreas de maior influência do reservatório nos níveis de água subterrânea, e considerando a malha de distribuição apresentada pelos poços cadastrados, foram definidos os locais mais adequados para a instalação dos poços de monitoramento previstos para a bacia do rio Biritiba-Mirim.

Instalaram-se poços de monitoramento ao longo das bordas da bacia de inundação, a fim de monitorar a variação dos níveis de água do aqüífero antes e após o enchimento. A perfuração dos poços de monitoramento permitiu, também, complementar as informações litológicas e de profundidade do nível freático adquiridas com a execução das sondagens e o cadastramento dos poços existentes na área. 
Foram instalados treze poços de monitoramento a montante da barragem, sete na margem direita do rio Biritiba-Mirim e seis na margem esquerda. Esses poços foram instalados nas imediações da curva topográfica $763 \mathrm{~m}$, com profundidades variáveis de acordo com a premissa de que a cota de base dos mesmos deveria ser a mesma da cota mínima de enchimento do reservatório $(752,5 \mathrm{~m})$ ou a do topo do cristalino, se antes atingido.

As sondagens foram realizadas com o trado motorizado HONDA GX120, e os furos revestidos com tubos de PVC de 1", com área previamente ranhurada de $1 \mathrm{~m}$ de comprimento (a partir da sua base).

\subsubsection{Posicionamento das estações de observação e de medição}

As coordenadas UTM dos poços cadastrados e poços de monitoramento instalados na área foram obtidas com o emprego do sistema DGPS (Differential Global Positioning System). O equipamento utilizado foi o modelo Pro.XL, fabricado pela empresa americana TRIMBLE.

O DGPS é um sistema de posicionamento por satélites de alta precisão, no qual uma estação GPS itinerante permanece estacionada, por um intervalo de tempo predeterminado, no ponto onde se deseja conhecer as coordenadas e, simultaneamente, uma estação base de referência é posicionada num ponto de coordenadas conhecidas (neste caso, a estação base utilizada localizou-se no Instituto de Pesquisas Tecnológicas - IPT, localizado no campus da Universidade de São Paulo - USP). Os dados adquiridos pela estação itinerante (estação de campo) e aqueles obtidos pela estação base são, posteriormente, processados em software dedicado (PathFinder Office, da Trimble), obtendo-se, assim, os resultados de posicionamento no sistema de coordenadas desejado, com precisão inferior a um metro.

A FIGURA 5.3 mostra o equipamento itinerante em operação num dos poços de monitoramento instalados.

Foram locados, com DGPS, os poços cadastrados e os de monitoramento instalados na bacia de Biritiba-Mirim. Os resultados do posicionamento encontram-se inseridos nas tabelas de informações geográficas e hidrogeológicas dos respectivos pontos.

As coordenadas apresentadas neste estudo estão no sistema UTM, zona 23, Datum Córrego Alegre. 


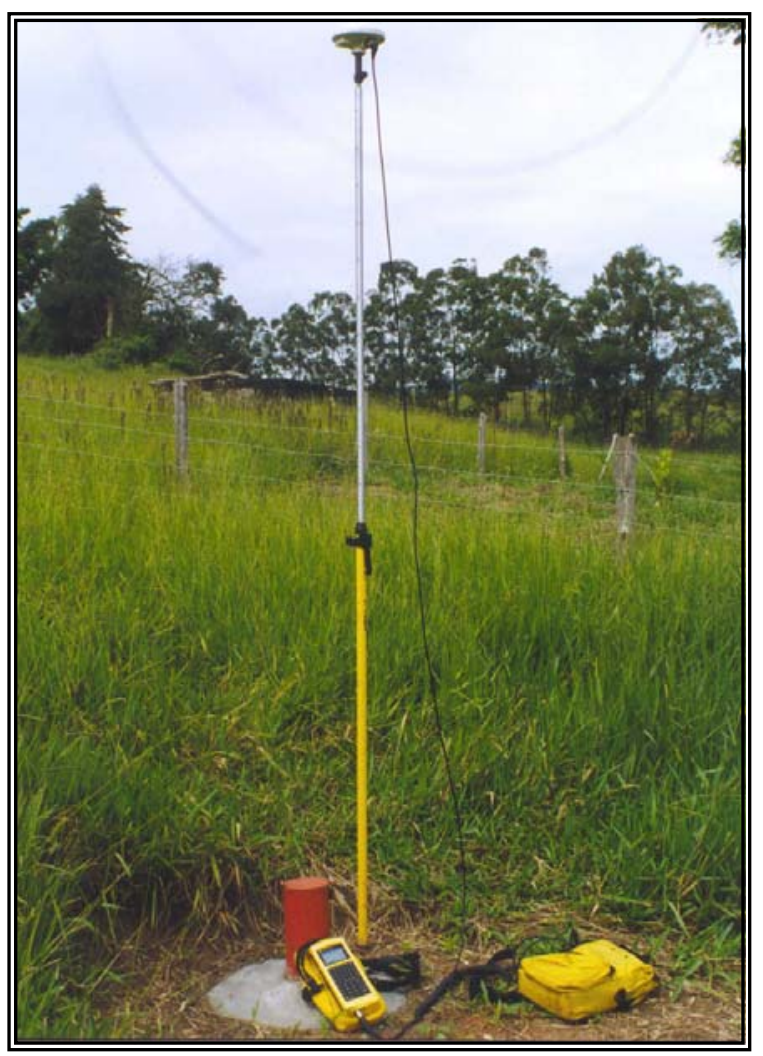

FIGURA 5.3 - Estação DGPS itinerante, em operação para determinação das coordenadas de um poço de monitoramento

\subsubsection{Verificação do modelo}

A verificação tem por objetivo avaliar se o modelo descreve de forma precisa os processos físicos que ocorrem no meio poroso. Com o objetivo de verificar a confiabilidade do modelo, foi utilizado o conjunto de parâmetros previamente calibrados para reproduzir um segundo conjunto de dados de campo, obtidos a partir das campanhas de monitoramento. 


\subsubsection{Campanhas de monitoramento}

Foi executado o plano de monitoramento do aqüífero livre durante o período de um ano, antes do enchimento do reservatório.

Para compor a rede de monitoramento do reservatório, foram selecionados poços previamente cadastrados e poços de monitoramento instalados na bacia de drenagem do rio Biritiba-Mirim. Nesses pontos, foram efetuadas medições da profundidade do nível d'água, por um período estipulado de um ano. Realizaram-se, ao todo, quatro campanhas de monitoramento do nível freático, nos meses de maio/junho/2000, setembro/2000, dezembro/2000 e março/2001. Os valores observados foram comparados, quando possível, com aqueles obtidos no período de coleta anterior.

Durante o período em que foram realizadas as campanhas de monitoramento, foi acompanhada, também, a precipitação mensal da área, por meio do posto pluviométrico do DAEE, localizado na barragem do reservatório de Biritiba-Mirim.

\subsubsection{Ensaios de permeabilidade}

Com o objetivo de ajustar o modelo, foram executados ensaios de permeabilidade em alguns poços de monitoramento; estes ensaios foram realizados de acordo com as orientações da ASSOCIAÇÃO BRASILEIRA DE GEOLOGIA DE ENGENHARIA - ABGE (1999) e orientações de execução em campo indicadas por OLIVEIRA \& CORRÊA FILHO (1996).

Nos ensaios, foi considerado o solo ensaiado como homogêneo e isotrópico, onde permanece válida a lei de Darcy.

Do ponto de vista hidrogeotécnico, o ensaio aplicado pode ser classificado como ensaio a nível variável, com diferencial de pressão positivo (carga), aplicado ao aqüífero. A FIGURA 5.4 apresenta um modelo esquemático de um poço de monitoramento e a fórmula utilizada para o cálculo do coeficiente de permeabilidade do terreno $(\mathrm{K})$.

O ensaio foi executado com os seguintes passos: encheu-se o furo até a boca, tomando-se este instante como tempo zero (mantendo o nível por, pelo menos, $10 \mathrm{~min}$.), interrompeu-se o fornecimento de água e, a intervalos predeterminados, acompanhou- 
se o rebaixamento do nível de água do furo. O ensaio foi dado por concluído após 45 minutos.

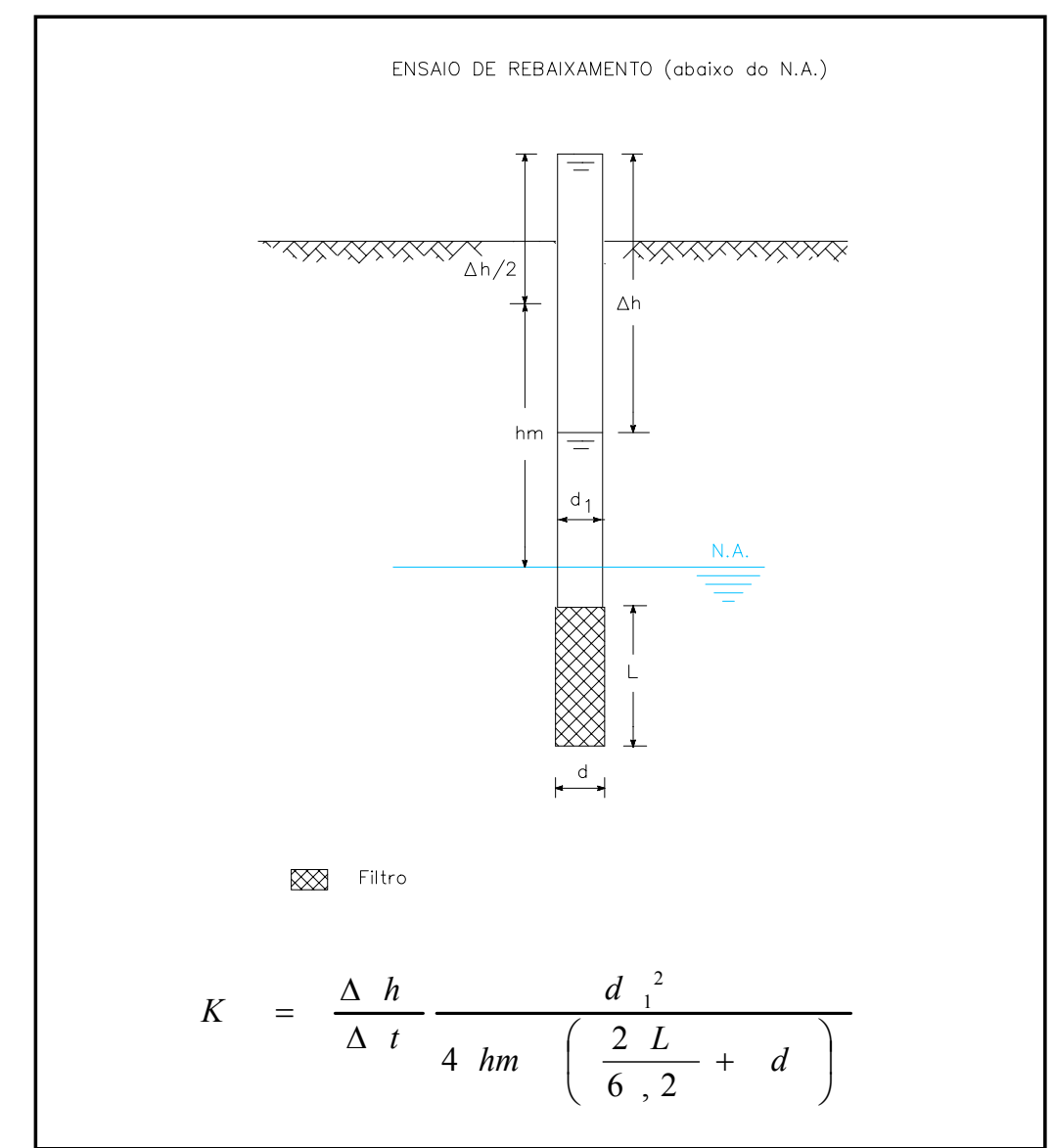

Fonte: modificado de OLIVEIRA \& CORRÊA FILHO (1996).

FIGURA 5.4 - Modelo esquemático de um poço de monitoramento e cálculo do coeficiente de permeabilidade do terreno $(\mathrm{K})$, aplicado em ensaios de rebaixamento

Foram realizados quatro ensaios de rebaixamento em quatro poços de monitoramento, escolhidos ao longo das margens do reservatório.

\subsection{Elaboração do Mapa Previsional de Influência do reservatório sobre o aqüífero livre}

A partir da verificação do modelo, foi simulado o enchimento do reservatório de Biritiba-Mirim, em caráter final e obtido, para a bacia de drenagem, o mapa potenciométrico final previsto. Utilizando-se do mapa planialtimétrico base, previamente 
digitalizado na escala 1:10.000, foi possível elaborar o mapa de zonas de profundidades do nível d'água subterrânea.

A elaboração do mapa de profundidades de níveis d'água subterrânea previstas após o enchimento do lago de Biritiba-Mirim, apresentado na escala de 1:25.000, permitiu destacar duas zonas de influência e uma zona sem influência do reservatório, de acordo com adaptação da metodologia proposta por ALBUQUERQUE FILHO (2002), para a elaboração do mapa de potencial de influência.

A avaliação do resultado do zoneamento, associada ao estudo do uso e ocupação do solo, resultou na identificação das áreas a serem mantidas em observação durante e após o enchimento do reservatório.

\subsection{1 Áreas de destaque quanto ao uso e ocupação do solo na margem do reservatório}

A partir de dados coletados na bibliografia, complementados pelas informações obtidas em campo, e das informações resultantes da simulação, foi possível definir as áreas de destaque quanto ao uso e ocupação do solo nas margens do reservatório.

\subsubsection{Proposta de monitoramento do aqüífero}

A partir da simulação do enchimento do reservatório, e dos parâmetros calibrados durante a verificação do modelo, foi simulada a resposta do nível freático em determinados períodos de tempo, após o enchimento do reservatório. Essa simulação permitiu elaborar o programa de monitoramento das cargas hidráulicas do sistema aqüífero livre, a ser executado após o enchimento do reservatório. 


\section{CARACTERIZAÇÃO DA ÁREA DE ESTUDO}

A caracterização física está fundamentada no levantamento da bibliografia existente sobre a área de estudo e dados complementares obtidos nos trabalhos de campo. Esta fase da pesquisa subsidia a compreensão da dinâmica do meio físico, introduzindo elementos para a elaboração do modelo conceitual da área de estudo e contribuindo para a definição das áreas de destaque quanto ao uso e ocupação do solo.

\subsection{Aspectos geológicos}

A área do reservatório de Biritiba-Mirim, inserida na bacia hidrográfica do Alto Tietê, está localizada na porção leste do Planalto Paulistano, ao sul do Lineamento de Cubatão. As estruturas do conjunto de rochas que ocorrem na região são geralmente concordantes com esse linhamento, com direção de $N 60^{\circ}-70^{\circ} \mathrm{E}$, e mergulhos acentuados para noroeste.

Esses terrenos correspondem aos domínios da Faixa Costeira, área de definição do Complexo Costeiro (HASUI et al., 1981) e da unidade que Rideg cartografou sobre a denominação de "Biritiba-Mirim-Migmatite" (apud CPRM, 1990).

$\mathrm{Na}$ faixa a norte, que inclui a área do eixo da barragem e com grande extensão tanto para leste como para oeste do reservatório, ocorrem as seqüências metavulcanossedimentares do Complexo Embu (HASUI, 1973, 1975). A maior parte dessa área caracteriza-se pela predominância de metassedimentos associados a migmatitos (PEe11), incluindo gnaisses paraderivados, rochas xistosas, quartzitos e, subordinadamente, cálcio-silicatadas e metabásicas. Distinguem-se os migmatitos de paleossoma xistoso (FIGURA 6.1), com neossoma quartzo-feldspático, de granulação desde fina a pegmatóide. Dominam solos muito desenvolvidos e com poucos afloramentos, sempre muito alterados. Em meio aos gnaisses bandados, aparece grande quantidade de budins de metabásicas, até ultrabásicas, e de cálcio-silicatadas associadas a ocorrências de bauxita (THEODOROVICZ et al., 1990). 


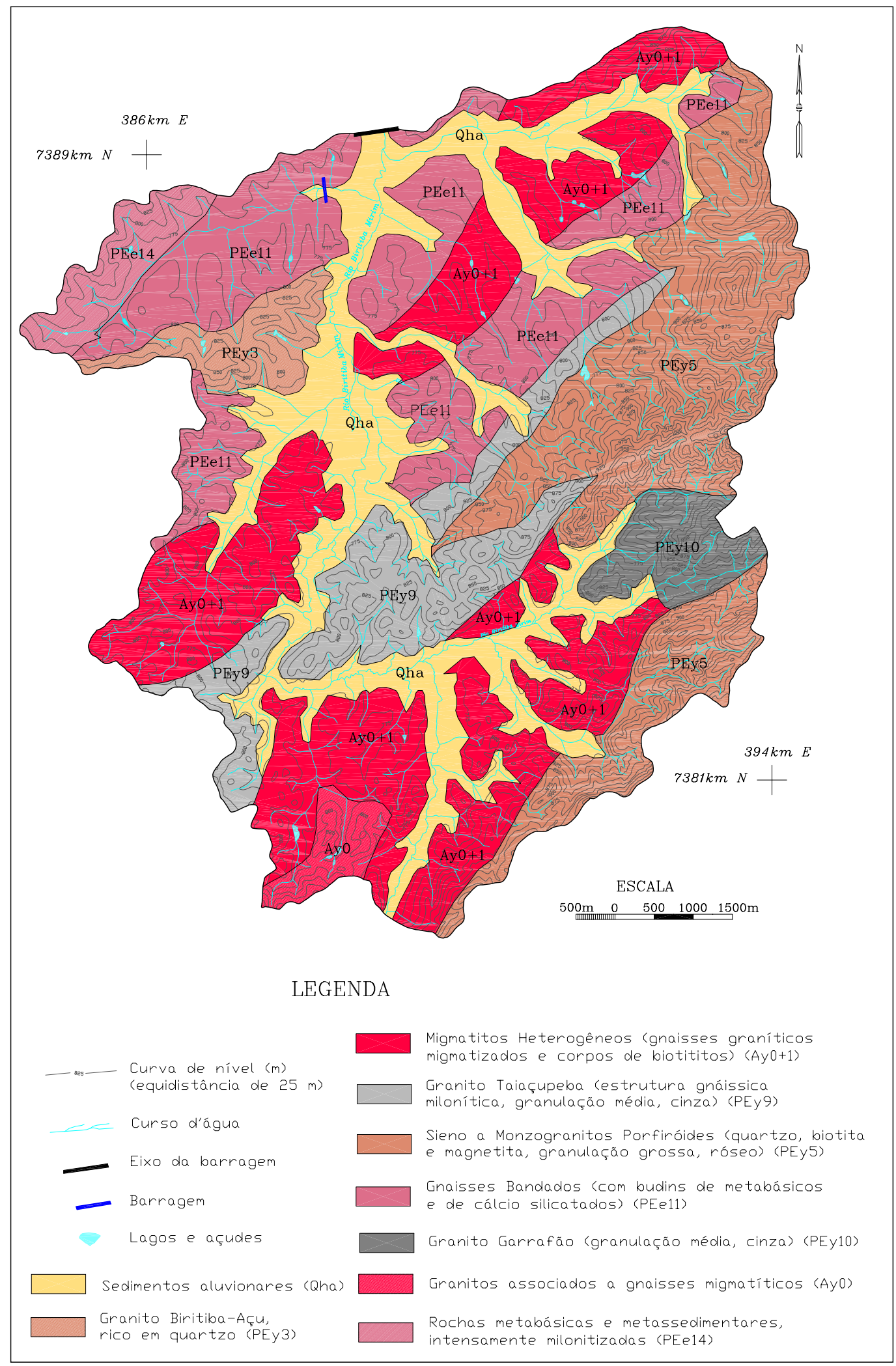

Fonte: modificado de THEODOROVICZ et al. (1990).

FIGURA 6.1 - Unidades geológicas da bacia de drenagem do rio Biritiba-Mirim 
Tal conjunto indica a presença do Complexo Embu no domínio do Bloco Costeiro (MOTIDOME, 1992), que ocorre a sul do Lineamento de Cubatão, cuja faixa de rochas miloníticas e xistos associados, de direção aproximada $\mathrm{N} 60^{\circ}-70^{\circ} \mathrm{E}$, situa-se a mais de $500 \mathrm{~m}$ a norte do eixo da barragem, passando também pela área urbana de BiritibaMirim.

De acordo com as sondagens a trado realizadas nessa área (ANEXO A), observou-se predominantemente a seguinte seqüência, do topo para a base: horizonte superficial rico em matéria orgânica, areia com presença de argila de cor marrom a preta até $5 \mathrm{~m}$, apresentando uma faixa argilosa de cor vermelha/marrom, de espessura variável, até os 7,0 $\mathrm{m}$ e areia de cor marrom clara a partir dessa profundidade e até 8,0 $\mathrm{m}$ (profundidade máxima das sondagens).

No extremo NW, o Complexo Embu destaca-se pelas seqüências vulcanossedimentares com associações formadas principalmente de rochas metabásicas e metassedimentares (PEe14), intensamente milonitizadas e alteradas, sendo o material de alteração essencialmente argiloso, branco, amarelo-esverdeado e/ou avermelhado.

O granito Taiaçupeba (Pey9) constitui um corpo expressivo, que se estende de forma alongada no sentido SW-NE e que aflora na forma de pequenos blocos e matacões com diâmetros inferiores a $1 \mathrm{~m}$. Trata-se de granitóide sintectônico (Fácies Cantareira), constituído por sieno a monzogranitos, desde pouco orientados a foliados, por vezes porfiróides, predominantemente equigranulares, homogêneos, de granulação fina a média, cor cinza, localmente róseo ou esbranquiçado, de estrutura gnássica milonítica, freqüentemente a duas micas e com raros xenolitos metassedimentares (THEODOROVICZ et al., 1990).

De acordo com as sondagens a trado realizadas nessa área (ANEXO A), observou-se predominantemente a seguinte seqüência, do topo para a base: horizonte superficial rico em matéria orgânica, areia de cor marrom a vermelha até $2,5 \mathrm{~m}$, areia com presença de argila da mesma cor até 5,0 m, incluindo uma faixa argilosa de cor acinzentada, de 1,0 $\mathrm{m}$ de espessura, e areia até 6,5 $\mathrm{m}$ (profundidade máxima das sondagens).

Na porção centro-leste, ocorre o Granito Garrafão (Peץ10), definido por Rideg como muscovita-biotita granito, discordante e de caráter pós-tectônico (apud CPRM, 1990). É caracterizado por leuco-granitos de cor cinza esbranquiçada de composição 
sienogranítica, textura equigranular fina a média, a duas micas, com muscovita superando a biotita em quantidade e tamanho dos cristais.

De acordo com a sondagem a trado realizada nessa área (ANEXO A), observouse predominantemente a seguinte seqüência, do topo para a base: horizonte superficial rico em matéria orgânica, areia com pouca argila marrom a preta até 4,5 $\mathrm{m}$ (profundidade máxima da sondagem), incluindo uma faixa argilosa de cor marrom escura, de 1,0 m de espessura, entre os 2,0 e 3,0 m de profundidade.

Um corpo de granito pós-tectônico ( $\mathrm{Pe} \gamma 3$ ) ocorre a oeste da área do reservatório (entre as coordenadas 7.385,8 e 7.387,6 km N, aproximadamente), margem esquerda do rio Biritiba-Mirim. Denominado como granito Biritiba-Açu, por Rideg (apud CPRM, 1990), encontra-se encaixado em rochas migmatíticas do Complexo Embu, sendo constituído por granitos de granulação média, textura equigranular ou porfiróide, caracterizado pela cor rósea e/ou cinza claros (bege, creme ou avermelhado, quando alterados), rico em quartzo e pobre em máficos. Ocorre na forma de raros matacões de porte médio, semi-alterados e exibindo cores amareladas, em conseqüência da oxidação dos seus componentes máficos.

A leste e extremo sudeste da bacia do rio Biritiba-Mirim, há ocorrência de sieno a monzogranitos porfiróides $(\operatorname{Pe} \gamma 5)$ de granulação grossa e cor rósea. São potássicos, ricos em quartzo, tendo como máficos principalmente biotita, com eventuais anfibólios sódicos, além de magnetita (THEODOROVICZ et al., 1990).

De acordo com a sondagem a trado realizada nessa área (ANEXO A), observouse predominantemente a seguinte seqüência, do topo para a base: horizonte superficial rico em matéria orgânica, areia marrom clara a escura com presença de seixos a partir dos 2,0 $\mathrm{m}$ (sondagem com profundidade de 3,5 m).

Numa faixa que se estende de centro-oeste a NE e em outra na extremidade sul da bacia, a sul do trecho onde o rio Biritiba-Mirim apresenta direção aproximada N70 ${ }^{\circ}$ $80^{\circ} \mathrm{E}$ e até as suas cabeceiras, ocorre uma unidade constituída por rochas granito/gnaisse "migmatíticas" $(\mathrm{A} \gamma 0+1)$, de aspecto textural extremamente diversificado, associadas a gnaisses graníticos e corpos de biotititos e/ou biotita.

De acordo com as sondagens a trado realizadas nessa área (ANEXO A), observou-se predominantemente a seguinte seqüência, do topo para a base: horizonte superficial rico em matéria orgânica, até 9,5 m (profundidade máxima das sondagens) 
areia de cor vermelha, marrom e até preta. Em alguns casos, presença de camadas mais argilosas de cor marrom.

No extremo sul da área, a sudoeste do rio Biritiba-Mirim, há uma pequena área com predomínio de rochas graníticas de textura porfiróide (A $\gamma 0)$. Apresentam granulação média e cor cinza clara, estando intimamente associadas a gnaisses migmatíticos (THEODOROVICZ et al., op. cit.). As rochas migmatíticas apresentam-se resistentes, geralmente alterando-se na forma esferoidal. Seus produtos de intemperismo são solos areno-argilosos de cor amarelo-avermelhada.

Ao longo das principais drenagens, destacam-se os depósitos fluviais (Qha), que possuem extensão mais restrita nos afluentes secundários e nas áreas de relevo mais acidentado. Apresentam-se na forma de planícies, com relevo plano e cotas pouco superiores ao nível dos rios, sofrendo inundações freqüentes durante épocas de intensa pluviosidade (DAEE, 1975).

De acordo com SUGUIO (1971), os depósitos fluviais estariam sendo representados por dois ciclos sedimentares: o primeiro composto por sedimentos areno-arcoseanos, mais espessos, e o segundo, por sedimentos síltico-argilosos mais jovens, recobrindo aqueles e estendendo-se pelas amplas planícies de inundação que acompanham as drenagens. Os depósitos principais são constituídos por camadas argilosas, ricas em material orgânico, às quais se intercala o material detrítico predominantemente grosseiro (DAEE, op. cit.). Pinto et al., realizando perfis de sondagens na periferia de Jundiapeba, constataram espessura média de $6 \mathrm{~m}$ para esses depósitos, e constituição litológica variando de conglomerado fino a areia, na base, até argila preta, muitas vezes turfáceas no topo (apud THEODOROVICZ et al., op. cit.).

De acordo com as sondagens a trado realizadas na área (ANEXO A), observouse predominantemente a seguinte seqüência, do topo para a base: horizonte superficial rico em matéria orgânica até $0,30 \mathrm{~m}$, areia de cor marrom até 2,5 m, areno-argiloso de cor marrom escuro a partir dessa profundidade e até 5,5 m (profundidade máxima das sondagens). 


\subsection{Aspectos geomorfológicos}

Do ponto de vista geomorfológico, a área do reservatório de Biritiba-Mirim está inserida na extremidade leste do Planalto Paulistano, sendo limitada a sudeste pelo Planalto de Paraitinga/Paraibuna. Esses dois planaltos constituem parte das zonas que compõem a unidade morfoestrutural do Planalto Atlântico, segundo a Divisão Geomorfológica do Estado de São Paulo (ROSS \& MOROZ, 1997).

A bacia do Biritiba-Mirim é alongada no sentido N-S. O padrão de drenagem é do tipo subdendrítico. Entretanto, sua rede de drenagem apresenta diversos cursos d'água afluentes do rio Biritiba-Mirim, e mesmo alguns trechos deste rio, com marcada direção N70E, evidenciando forte controle pelas estruturas das rochas do embasamento cristalino, associadas à Zona de Cisalhamento de Cubatão.

Dentro do Planalto Paulistano/Alto Tietê, a área da bacia situa-se no compartimento de relevo Morraria do Embu. PONÇANO et al. (1981a e 1981b) destacam três formas de relevo nesse compartimento:

a) Morros Alongados Paralelos: declividades em geral acima de $15 \%$ e amplitudes locais inferiores a $100 \mathrm{~m}$; topos arredondados, vertentes com perfis retilíneos a convexos, drenagem densa, com padrão paralelo em treliça, e vales fechados;

b) Morros com Serras Restritas: topos arredondados, declividade acima de $15 \%$, amplitudes locais entre 100 e 300 m, vertentes com perfis retilíneos (por vezes abruptas) e presença de serras restritas; drenagem densa, padrão dendrítico a pinulado, vales fechados e planícies aluvionares interiores restritas;

c) Planícies Aluviais: junto ao vale do rio Biritiba-Mirim e dos seus principais tributários.

A zona de cabeceira do rio Biritiba-Mirim é constituída por relevo de Morros, Serras e Montanhas, com amplitudes em geral superiores a $100 \mathrm{~m}$ e declividades médias a altas. No restante da bacia, na zona de baixo curso, predominam relevos de Colinas e Morrotes e Planícies Fluviais, com pequenas porções onde ocorrem relevos de Morrotes e Morros e Morrotes Paralelos (PIRES NETO, 1992) (FIGURA 6.2). 
Os relevos de Colinas e Morrotes apresentam amplitudes de 30 a $75 \mathrm{~m}$, vertentes com declividades de 10 a 15\% e altitudes variáveis de 780 a 800 m (cotas mínimas em torno de 760 m e máximas de 850 m). Em termos geológicos, predominam nesses terrenos metassedimentos, associados a migmatitos (PEe11) e rochas granito/gnaisse "migmatíticas" $(\mathrm{A} \gamma 0+1)$.

A planície fluvial compreende a planície de inundação e baixos terraços. São terrenos baixos e inclinados em direção ao canal, associando-se com áreas alagadas e pantanosas. Essas áreas apresentam substrato geológico constituído por areias e até seixos e lentes de material argilo-siltoso (Qha).

Os relevos de Morros, Serras e Montanhas apresentam amplitudes de 100 a 420 $\mathrm{m}$, vertentes com declividades de 20 a $53 \%$. Esse tipo de relevo ocorre associado a substrato de sieno a monzogranitos porfiróides (Pe $\gamma 5)$.

Os relevos de Morrotes e Morros apresentam amplitudes de 60 a $160 \mathrm{~m}$, vertentes com declividades de 13 a 40\%. Apresentam forma de topos amplos, convexos e forma de topos estreitos. O perfil das vertentes é convexo e, em alguns locais, retilíneo. Os vales são estreitos e apresentam padrão de drenagem dentrítico e subparalelo, de média a alta densidade. Em termos geológicos, estão predominantemente associados a sieno e monzogranitos sintectônico, da formação

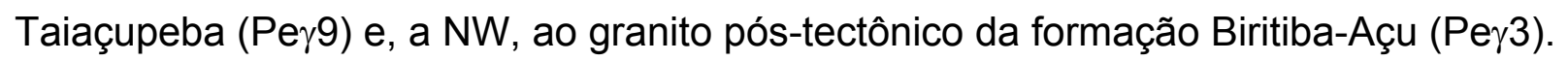




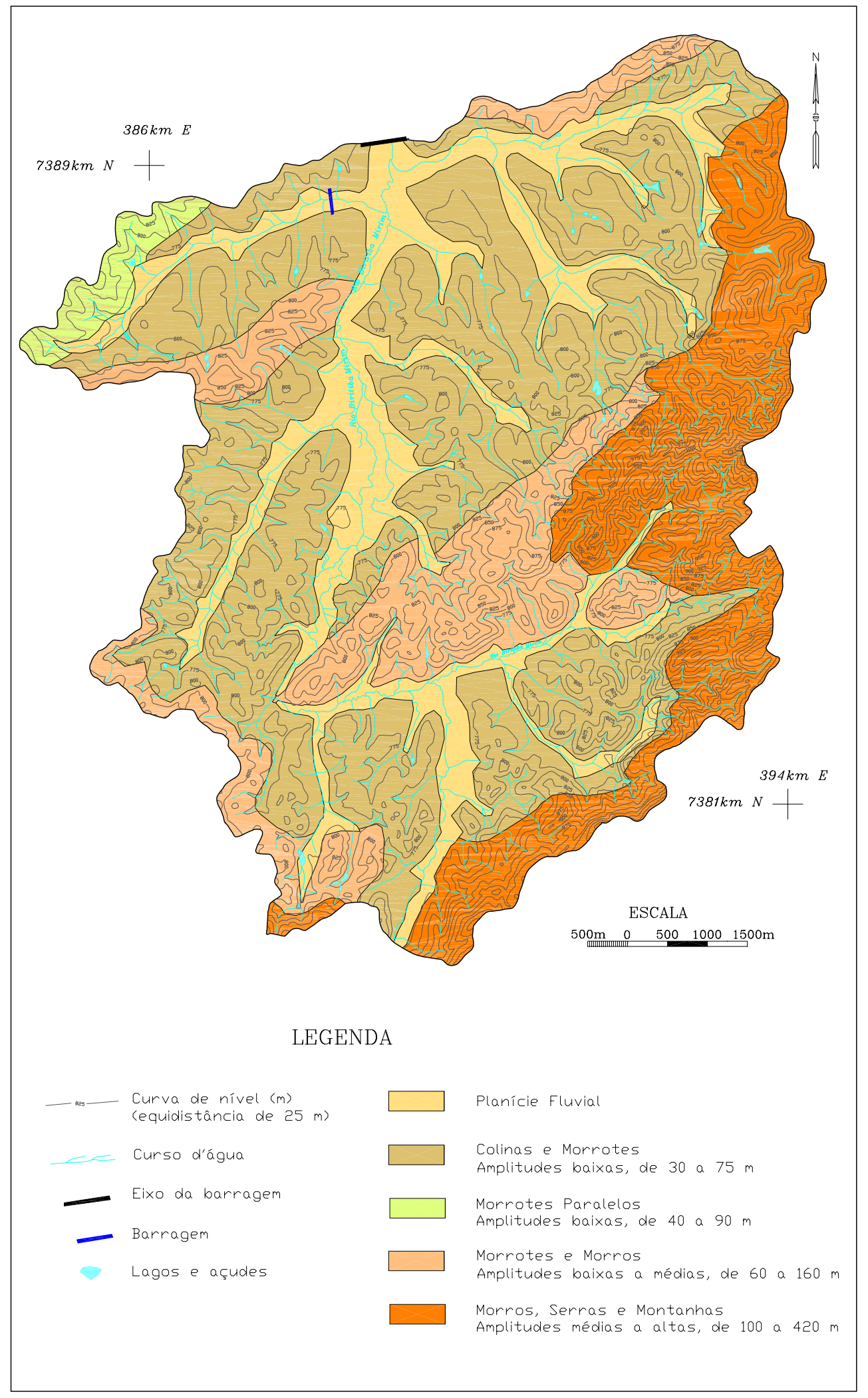

Fonte: modificado de PIRES NETO (1992).

FIGURA 6.2 - Unidades geomorfológicas da bacia de drenagem do rio Biritiba-Mirim 
Os relevos de Morrotes Paralelos apresentam amplitudes de 40 a $90 \mathrm{~m}$, vertentes com declividades de 23 a 50\%. Apresenta forma de topos estreitos, perfis de vertentes retilíneos, vales estreitos e encaixados com padrão de drenagem em treliça e paralelo de alta densidade. Em termos geológicos, estão predominantemente associados a rochas vulcanossedimentares, com associações formadas principalmente de rochas metabásicas e metassedimentares (PEe14).

\subsection{Hidrogeologia}

Na região, as unidades hidrogeológicas estão diretamente relacionadas com as rochas cristalinas e com os sedimentos quaternários das áreas de inundação, podendo ser diferenciados dois tipos de unidades aqüíferas: o Sistema Aqüífero Sedimentar (SAS), que se estende sobre uma pequena parte da região, ao longo das drenagens principais, e o Sistema Aqüífero Cristalino (SAC), que ocupa o restante da área (HIRATA \& FERREIRA, 2001).

O Sistema Aqüífero Sedimentar (SAS) é representado, na área de estudo, pelo Aqüífero Quaternário, composto por depósitos sedimentares aluviais predominantemente areno-argilosos. Essa unidade ocupa as planícies das principais drenagens da área, apresentando larguras irregulares de 200 a 1.000 m e espessura média da ordem de $7 \mathrm{~m}$. Este sistema é comumente explorável por meio de poços cacimbas.

O Sistema Aqüífero Cristalino (SAC) apresenta características hidráulicas diferenciadas, dependendo do tipo de litologia. HIRATA \& SILVA (1999) distinguiram duas unidades na região estudada (FIGURA 6.3):

a) associação de rochas granitóides e rochas gnássicas (Aqüífero $A$ ): aqüífero livre onde as melhores vazões estão associadas às falhas e fraturas nas rochas; possui vazão média de $9,1 \mathrm{~m}^{3} / \mathrm{h}$ e capacidade específica de 0,2 $\mathrm{m}^{3} / \mathrm{h} / \mathrm{m}$;

b) associação de rochas metassedimentares (Aqüífero B): aqüífero livre onde as melhores vazões estão associadas às falhas e fraturas nas rochas; possui vazão média de $17,5 \mathrm{~m}^{3} / \mathrm{h}$ e capacidade específica de $1,4 \mathrm{~m} 3 / \mathrm{h} / \mathrm{m}$. 


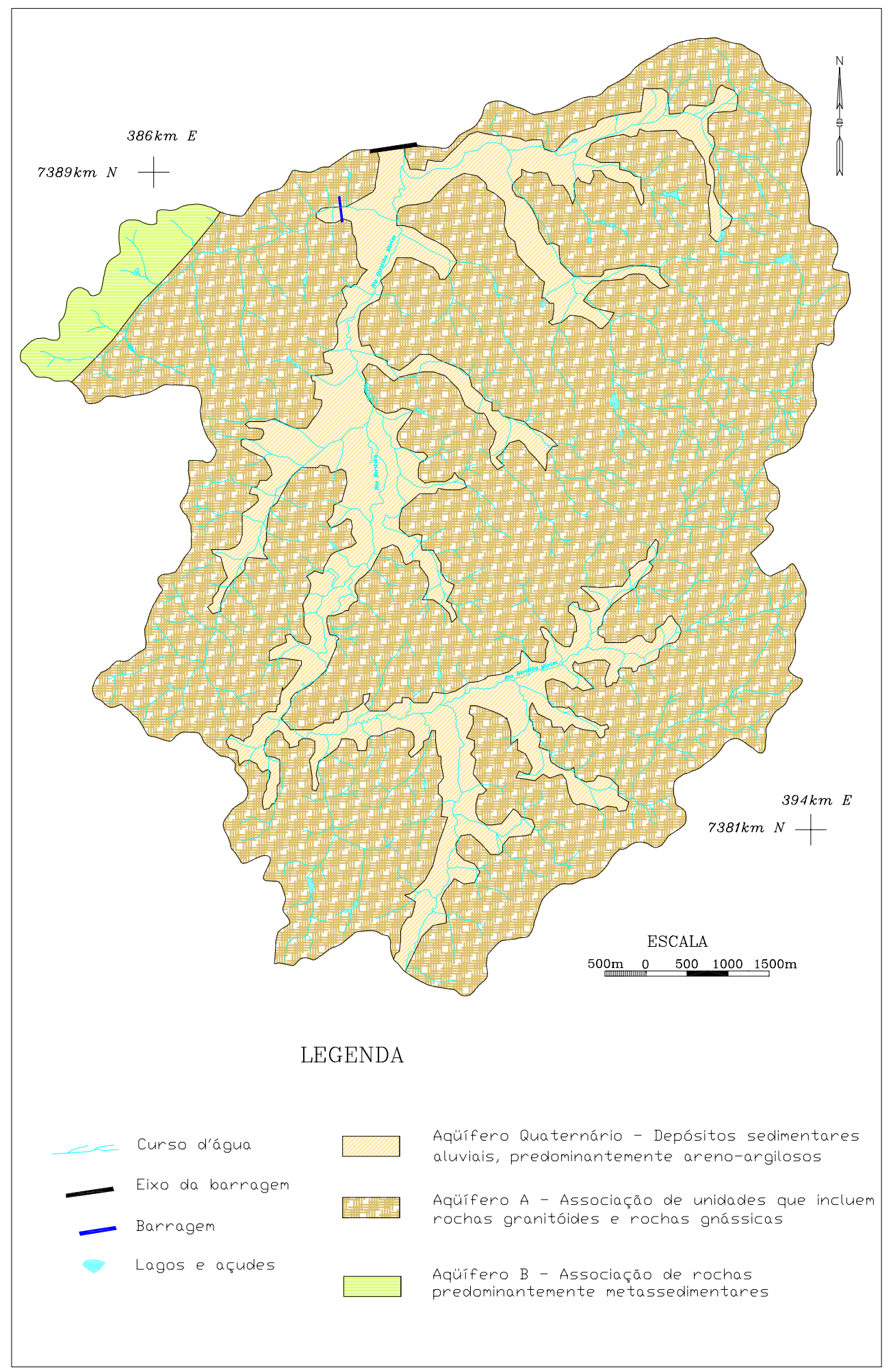

Fonte: modificado de HIRATA \& SILVA (1999).

FIGURA 6.3 - Mapa hidrogeológico da área da bacia do reservatório de Biritiba-Mirim 
A ocorrência de água explotável nas rochas cristalinas decorre da presença de fraturas e falhas e da decomposição mecânica ou alteração parcial da rocha. Podem ser distinguidos três graus de alteração da rocha cristalina:

a) rocha resistente (textura conservada, com feldspatos decompostos, mas ainda identificáveis, e a biotita com a sua coloração modificada);

b) semi-alterada (a textura da rocha pode ser identificada e a sua resistência ainda existe);

c) alteração total (minerais totalmente decompostos).

Portanto, no Sistema Aqüífero Cristalino pode ser observada uma parte inalterada (ou sã), cuja água escoa somente nas descontinuidades rúpteis da rocha, e outra alterada, onde o escoamento ocorre nos interstícios da rocha intemperizada.

A espessura da rocha decomposta não é uniforme, variando segundo as condições topográficas, tipo de rocha e o seu grau de intemperismo. De acordo com HIRATA \& FERREIRA (2001), na bacia hidrográfica do Alto Tietê, a espessura média desse aqüífero heterogêneo, de porosidade granular, é de $50 \mathrm{~m}$.

Abaixo da camada intemperizada, encontra-se a rocha relativamente sã, ou aqüífero cristalino propriamente dito, de caráter livre a semi-confinado, heterogêneo e anisotrópico (HIRATA \& FERREIRA, op. cit.). Estudos realizados pelo DAEE (1975) na Grande São Paulo, indicaram que o aqüífero cristalino principal está localizado a profundidades de $120-150 \mathrm{~m}$.

Nas rochas cristalinas da região, as condições de relevo e de cobertura do solo propiciam a formação de um aqüífero contínuo, localizado na camada intemperizada e controlado pela rede de drenagem. A recarga natural escoa através das camadas do solo para as camadas cristalinas alteradas, alimentando, de forma eficiente, as falhas e fraturas do maciço rochoso subjacente. Porém, não pode escoar dessas camadas para a parte inalterada, sendo armazenada e escoando em direção aos rios e riachos próximos, constituindo a drenagem das águas superficiais.

De acordo com DAEE (op. cit.), o Sistema Aqüífero Cristalino comporta-se de forma similar em toda a região da Grande São Paulo, caracterizando-se pela baixa produtividade. Na região de Mogi das Cruzes e suas vizinhanças, a produção de poços perfurados nesse aqüífero foi considerada pequena, pois os mesmos apresentaram capacidade específica média da ordem de $0,24 \mathrm{~m}^{3} / \mathrm{h} / \mathrm{m}$. Outros testes realizados por 
CAVALCANTE (1990) no manto de intemperismo da região de Atibaia (SP), indicaram uma capacidade específica média de $0,25 \mathrm{~m}^{3} / \mathrm{h} / \mathrm{m}$. Esse dado está de acordo com a capacidade especifica de unidades aqüíferas associadas a rochas granitóides (Aqüíferos de Rochas Granitóides), cujo valor médio indicado é de $0,20 \mathrm{~m} / \mathrm{h} / \mathrm{m}$ (HIRATA \& FERREIRA, 2001).

O valor de transmissividade observado nos poços que captam água do aqüífero cristalino oscila entre 0,4 e $14 \mathrm{~m}^{2} / \mathrm{d}$, sendo a média de $3,5 \mathrm{~m}^{2} / \mathrm{d}$ (DAEE, 1975). SABESP-CEPAS (1994) determinaram, para o SAC, uma porosidade eficaz (Sy) de $3 \%$ enquanto que segundo o DAEE (op. cit.) esse parâmetro oscila entre 0,5 e 5\%.

REBOUÇAS (1992), estudando as características hidráulicas da porção intemperizada do SAC, observou que as condutividades hidráulicas variam de muito baixas $\left(8,64 \times 10^{-2}\right.$ a $\left.8,64 \times 10^{-3} \mathrm{~m} / \mathrm{d}\right)$, no terço superior do perfil de alteração, a muito alta (86,4 a 8,64 m/d), na zona de transição entre a rocha relativamente alterada e a rocha sã. CAVALCANTE (op. cit.) também observou condutividades hidráulicas baixas, com valores de $8,64 \times 10^{-1}$ a $8,64 \times 10^{-3} \mathrm{~m} / \mathrm{d}$, ao estudar o manto de alteração na região próxima de Atibaia, confirmando a sua interação com o meio fraturado.

O Sistema Aqüífero Sedimentar (SAS), representado pelo Aqüífero Quaternário, corresponde aos depósitos aluvionares inconsolidados, com ocorrência restrita às planícies fluviais. Em determinadas áreas, a pequena espessura dos sedimentos não possibilita a existência de um aqüífero amplo e profundo, que possa ser considerado uma fonte significativa a ser explotada.

Apesar da existência de camadas argilosas no aqüífero aluvial, existe ligação hidráulica entre as camadas transmissoras, relacionando cada trecho explorado com um nível freático, capaz de influir sobre uma extensa área.

De acordo com o DAEE (op. cit.), o coeficiente de transmissividade (T) dos aqüíferos sedimentares da Bacia do Alto Tietê (BAT) oscila entre 15 e $70 \mathrm{~m}^{2} / \mathrm{d}$, sendo que a média é de cerca de $50 \mathrm{~m}^{2} / \mathrm{d}$. Esse valor é razoável, considerando que a maior parte da seção sedimentar é argilosa e que as camadas arenosas são muito finas. De acordo com o autor, o coeficiente de armazenamento (S) varia de $2 \%$ a $10 \%$, devido ao caráter litológico das camadas sedimentares, enquanto que SABESP-CEPAS (1994), atribuem para o SAS um coeficiente de armazenamento médio de $1 \%$. 


\subsection{Aspectos climatológicos}

Segundo a classificação de Köppen, a área de interesse insere-se predominantemente em região com clima Cwb (clima úmido, temperado, com inverno seco), estando limitada ao norte por áreas com clima Cwa (úmido, quente, inverno seco) e ao sul por região com clima Cfb (úmido, temperado, sem estação seca).

No cálculo da precipitação média anual da bacia do rio Biritiba-Mirim foram utilizados dados do posto pluviométrico de Sertãozinho, coletados no período de 1971 a 1999 (DAEE, 2000). A estação (código E3-231) está localizada nas coordenadas UTM 7.387.785 m N e 389.484 m E, no município de Biritiba-Mirim, na altitude de 740 m. A influência orográfica proporciona índices pluviométricos elevados, da ordem de $1.501 \mathrm{~mm}$ por ano.

A estimativa de evapotranspiração foi realizada de acordo com o método recomendado pela FOOD AND AGRICULTURE ORGANIZATION OF UNITED NATIONS - FAO (VILLA NOVA et al., 1980), que considera os valores médios mensais de umidade relativa (UR\%) e velocidade do vento (v). Foram utilizados dados da estação climatológica de Casa Grande, coletados no período de 1975 a 1992. A estação climatológica (código E2-110-HM), assim como a própria bacia de drenagem de Biritiba, está localizada próxima à Serra do Mar, nas coordenadas UTM 7.386.080 m N e 409.899 m E, no município de Salesópolis. A evaporação média anual, medida em tanque Classe A, foi de aproximadamente $876,6 \mathrm{~mm}$ (SONDOTÉCNICA, 1996). A umidade relativa do ar apresentou valores médios anuais da ordem de $88 \%$, enquanto que o regime de ventos caracterizou-se por velocidades médias, aproximadas de $7 \mathrm{~km} / \mathrm{h}$.

A evapotranspiração média anual da área foi calculada de acordo com a seguinte equação:

$$
E t_{o}=K_{p} E C A
$$

Na qual,

$E t_{o}=$ Evapotranspiração potencial [L/T]. Evapotranspiração ocorrente em uma superfície vegetada com grama, bem provida de umidade, em fase de desenvolvimento ativo, e com bordadura adequada (VILLA NOVA et al. 1979). 
$K_{p}=$ Coeficiente de tanque. Valor dependente da umidade relativa (UR\%) e velocidade do vento (v) [adim.].

$E C A=$ Evaporação do tanque classe $\mathrm{A}[\mathrm{L} / \mathrm{T}]$.

Utilizando os valores descritos, e considerando o tanque classe A colocado em área não cultivada, com bordadura de até $10 \mathrm{~m}$, obtem-se:

$$
\begin{aligned}
E t_{o} & =0,8 \times 876,6 \mathrm{~mm} / \mathrm{ano} \\
E t_{o} & =701,3 \mathrm{~mm} / \mathrm{ano} \\
& =0,00192 \mathrm{~m} / \mathrm{d}
\end{aligned}
$$

\subsection{Características do uso e ocupação do solo na área bacia}

A bacia de drenagem encontra-se situada sobre solos ricos em ferro e alumínio, e apresenta como principais usos do solo a agricultura intensiva, a silvicultura e as pastagens e capoeiras, com importante presença de formações florestais nativas.

De acordo com CCN (1997), a área total da bacia hidrográfica é de $75,49 \mathrm{~km}^{2}$, sendo que $9,36 \mathrm{~km}^{2}$ da área é composta por várzeas, $16,00 \mathrm{~km}^{2}$ apresenta atividade de silvicultura, 30,97 km² ocupação rural densa, e 19,16 km² capoeira e pastagens.

As atividades rurais caracterizam-se pela presença de minifúndios produtivos e mecanizados, principalmente na adoção de irrigação por aspersão e na utilização de maquinarias e implementos agrícolas. A principal atividade agrícola é a horticultura, com produção de verduras como alface, repolho e couve e, nas estações frias, cenoura (CCN, op. cit.). A atividade granjeira é também de destaque na bacia, devido à grande extensão de área que ocupa.

A área no entorno do reservatório insere-se numa paisagem tipicamente rural. Remanescentes naturais dominam grande parte das planícies fluviais e se estendem, no geral, às vertentes dos morrotes e morros que circundam os vales.

A área total desapropriada foi de $12.832 .776,70 \mathrm{~m}^{2}$, afetando 210 propriedades rurais. No que se refere ao uso do solo e cobertura vegetal, destacam-se na área de inundação, as várzea e os campos antrópicos cultivados (TABELA 6.1). 
TABELA 6.1 - Uso do solo e a cobertura vegetal na área de inundação.

\begin{tabular}{lrc}
\hline \multicolumn{1}{c}{ Tipo de uso } & Área $\left(\mathrm{m}^{2}\right)$ & Área $(\%)$ \\
\hline Cobertura florestal nativa & 1.700 .000 & 18,40 \\
Várzeas (campos úmidos) & 3.790 .000 & 41,01 \\
Campos antrópicos sem uso aparente & 510.000 & 5,52 \\
Campos antrópicos cultivados & 2.455 .000 & 26,57 \\
Reflorestamento & 785.000 & 8,50 \\
TOTAL & 9.240 .000 & \\
\hline
\end{tabular}

Fonte: CCN (1997)

O mapeamento do uso do solo e cobertura vegetal baseou-se na interpretação de pares estereoscópicos. Foram interpretadas fotografias de 1981, na escala 1:35.000 (CCN, 1997).

Considerando-se que a bacia apresenta ocupação rural esparsa, e que $41 \%$ da área vem sendo utilizada principalmente no desenvolvimento de atividades agrícolas, destacam-se duas possíveis fontes de contaminação do aqüífero livre na região: a de origem agrícola e a de origem doméstica.

A elevação do nível freático, induzida pelo enchimento do reservatório, pode, em algumas áreas, desencadear ou acelerar o processo de contaminação do aqüífero. $O$ estudo dessas fontes tem por objetivo identificar as áreas de destaque dentro da bacia de contribuição do reservatório.

\subsubsection{Atividades agrícolas}

A contaminação difusa de origem agrícola é relevante para a proteção dos mananciais, pelo seu impacto negativo devido ao uso em grande escala de adubos, principalmente contendo nitrogênio e fósforo; defensivos, oriundos do uso de pesticidas; e outros produtos similares de grande solubilidade, que podem migrar em direção aos rios e aqüíferos.

Outra fonte de contaminação provém da criação de animais em sistemas intensivos confinados, como é o caso da avicultura e a suinocultura, que tendem a gerar efluentes mais concentrados do que nos sistemas de criação extensiva, podendo aumentar o aporte de matéria orgânica para o manancial. 
Os nutrientes solúveis migram para o meio natural por meio de lixiviação e de drenagem superficial das áreas de uso agropecuário. A importância desses fluxos depende de parâmetros como a natureza das atividades, o manejo agrícola, a existência de infra-estrutura de irrigação ou drenagem, a constituição dos solos, entre outros. Além disso, a contribuição de nutrientes de origem agropecuária varia com a época do ano, devido à sazonalidade da atividade agrícola e à influência dos fatores climáticos.

No geral, o aporte de nutrientes acelera o processo de eutrofização, já que disponibiliza insumos para o crescimento de organismos produtores primários.

A agricultura intensiva (essencialmente composta por hortifrutigranjeiros) libera quatro tipos principais de nutrientes: nitrogênio, fósforo, potássio e matéria orgânica; e três grandes tipos de defensivos: herbicidas, fungicidas e inseticidas.

Entram na composição dos defensivos tradicionais moléculas orgânicas, organofosforados, piretróides e íons metálicos, de difícil degradação em ambientes naturais. Amplamente utilizados na agricultura intensiva, que os emprega de forma rotineira, estes são parcialmente exportados com as safras, parcialmente fixados e degradados no solo e, ainda, parcialmente lixiviados em direção aos mananciais, pelas águas de chuva e de irrigação.

As zonas de capoeira, pastagens e áreas de transição não contribuem significativamente para o aumento dos fluxos de nutrientes transportados em direção aos mananciais. Nestas áreas são encontradas atividades extensivas, que não requerem aplicação de adubos ou defensivos em quantidades significativas. O mesmo se aplica às áreas ocupadas por silvicultura e reflorestamento.

As atividades agrícolas de maior relevância sobre os fluxos de nutrientes e defensivos agrícolas são a olericultura e a criação de suínos e aves em sistemas intensivos.

A maior parte dos nutrientes aplicados nas lavouras são consumidos pelas plantas sendo exportados com as safras ou fixados na matéria orgânica dos solos. Outra parte destes nutrientes pode ser lixiviada e atingir o nível freático ou, pelo escoamento, corpos d'água superficiais.

A CCN (1997) estimou um coeficiente médio de lixiviação do nitrogênio da ordem de $25 \mathrm{Kg} /$ ha por ano, num fluxo total de 280 toneladas por ano transmitidas ao sistema hídrico para toda a área de estudo (incluindo as atividades de pecuária 
intensiva). Adotando o coeficiente teórico de $5 \mathrm{Kg} /$ ha por ano, o fluxo total de fósforo de origem agropecuária atingiria a 120 toneladas por ano, incluindo-se as 80 toneladas oriundas da pecuária. A fraca mobilidade do fósforo condiciona que a principal causa de migração decorra do transporte de matéria sólida por processos erosivos.

No que se refere à quantidade de pesticidas, a aplicação é pouco significativa, ocorrendo em áreas menores e distantes do reservatório (CCN, op. cit.).

\subsubsection{Saneamento básico}

De acordo com o censo do IBGE (1991), apenas 28,1\% do total de 4.154 domicílios cadastrados no município de Biritiba-Mirim, encontram-se ligados à rede geral de esgotos, sendo estes lançados in natura em cursos d'água. A principal alternativa de tratamento de esgotos, praticada pela população não atendida pelo serviço público, é a fossa seca $(49,7 \%)$, sendo seguida pela fossa séptica em $15 \%$ dos casos.

No que se refere ao uso da água, estudos realizados pelo CONSÓRCIO HIDROPLAN (1995) concluíram que as águas subterrâneas representam um importante recurso na região, já que é utilizada para abastecer parcialmente o município de Biritiba-Mirim.

As estatísticas do censo de 1991 (IBGE, op. cit.), sobre o sistema de abastecimento de água nos setores censitários predominantemente rurais, indicaram a precariedade da infra-estrutura existente: 96\% dos domicílios nesses setores utilizam poços ou nascentes como forma de abastecimento.

Em relação ao esgotamento sanitário na área rural, a maioria não conta com serviço de coleta de esgotos, e tem como principal alternativa para o despejo dos efluentes domésticos, o emprego de fossas secas, seguido pelo uso de fossas sépticas. 


\section{MODELO CONCEITUAL}

O modelo conceitual deverá ser uma representação válida das características hidrogelógicas relevantes. É desejável que o modelo conceitual seja simplificado o máximo possível, mas que, ainda assim, contenha suficiente complexidade de modo a reproduzir adequadamente o comportamento do sistema (ANDERSON \& WOESSNER, 1992).

Foram seguidas três etapas na construção do modelo conceitual da bacia de drenagem do rio Biritiba-Mirim:

1) definição das unidades hidrogeológicas;

2) definição do sistema de fluxo; e

3) preparação do balanço hídrico.

\subsection{Caracterização das unidades hidrogeológicas}

As informações geológicas são combinadas com as informações das propriedades hidrogeológicas dos meios, para caracterizar as unidades hidrogeológicas. SEABER (1988) propõe o conceito de hidroestratigrafia para definir as unidades geológicas que possuem propriedades hidrogeológicas similares. De acordo com ANDERSON \& WOESSNER (1992), o conceito de unidade hidroestratigráfica é de grande utilidade nas simulações de sistemas geológicos em escala regional.

A partir de estudo existentes acerca da geologia, geomorfologia e hidrogeologia, foram diferenciados dois sistemas aqüíferos na área estudada:

a) o Sistema Aqüífero Sedimentar (SAS), que se estende ao longo das drenagens principais, sendo constituído, predominantemente, por camadas argilosas ricas em material orgânico, intercaladas ao material detrítico grosso, com espessura média de $7 \mathrm{~m}$; e

b) o Sistema Aqüífero Cristalino (SAC), no qual podem ser distinguidas duas unidades:

a) a unidade alterada, onde o escoamento ocorre nos interstícios da rocha intemperizada. É heterogêneo, de porosidade granular, tendo espessura média regional de 50 m (HIRATA \& FERREIRA, 2001). 
Estudos realizados por CAVALCANTE (1990) indicaram condutividade hidráulica entre $8,64 \times 10^{-1}$ e $8,64 \times 10^{-3} \mathrm{~m} / \mathrm{d}$ e confirmaram a interação dessa unidade alterada com o meio fraturado.

b) a unidade inalterada (ou sã), na qual a água escoa somente nas descontinuidades rúpteis da rocha, constitui o aqüifero cristalino propriamente dito, de caráter livre a semi-confinado, heterogêneo e anisotrópico, cujas principais fraturas alimentadoras de poços perfurados na região localizam-se a profundidades de 120-150 m (DAEE, 1975). Essa unidade apresenta transmissividade média de 3,5 $\mathrm{m}^{2} / \mathrm{d}$, e porosidade eficaz (Sy) média de 3\% (SABESP-CEPAS, 1994).

Nas rochas cristalinas da região, as condições de relevo e de cobertura do solo propiciaram a formação de um aqüífero contínuo localizado na camada intemperizada (SAC, unidade alterada). A recarga natural alimenta as falhas e fraturas do maciço rochoso subjacente (SAC, unidade inalterada), sendo armazenada e escoando em direção aos rios e riachos próximos (SAS e SAC). Existe, portanto, conexão hidráulica entre as camadas transmissoras, relacionando cada trecho explorado com um nível freático capaz de influir sobre uma extensa área.

Os dados coletados em campo (ANEXOS A e B) complementaram as informações acima referidas, contribuindo para a caracterização das unidades hidrogeológicas do modelo conceitual apresentados na FIGURA 7.1. 
a)

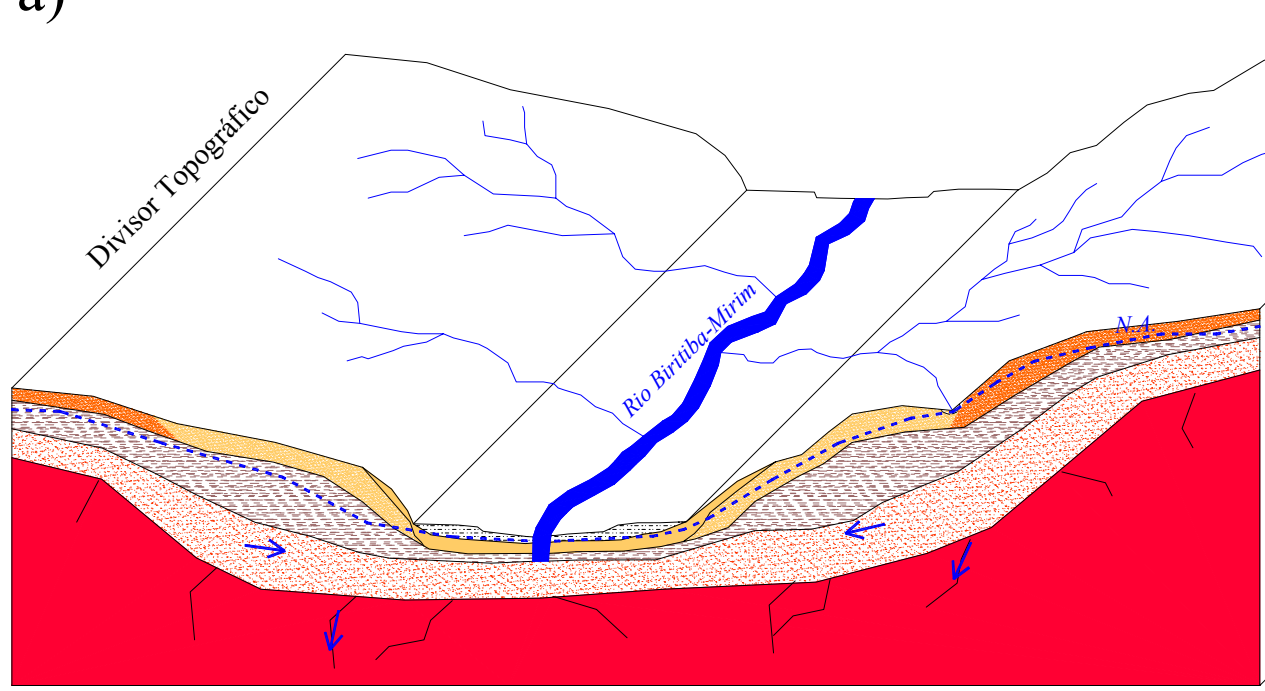

(sem escala)

LEGENDA

\begin{tabular}{llll}
\hline Argila & Argila orgânica & Solo silto-argiloso e silto arenoso \\
$\square$ & Areias e cascalhos finos & $\square$ & Rocha semi-alterada \\
$\square$ & Solo argilo-arenoso & Cristalino \\
$\square$ & Rocha alterada & Falha/Fratura
\end{tabular}

b)

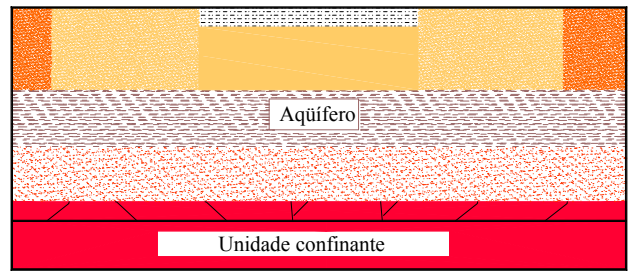

FIGURA 7.1 - Transferência das informações geológicas para o modelo conceitual

a) Figura esquemática das unidades geológicas.

b) Figura esquemática das unidades hidrogeológicas no modelo conceitual. 


\subsection{Definição do sistema de fluxo}

As cargas hidráulicas foram utilizadas para estimar a direção do fluxo das águas subterrâneas, localizar as áreas de recarga e de descarga e a conexão com o sistema de águas superficiais. Essas informações permitem entender o movimento das águas subterrâneas no sistema, representando um importante instrumento na identificação das unidades com propriedades hidrogeológicas similares, conforme indicado em WEISS \& WILLIAMSON (1985).

As informações das sondagens realizadas no local indicaram as cargas hidráulicas variando de 759,0 m (SB-05) a 783,0 m (SB-20), com valor médio de 770 m (ANEXO A). No que se refere ao cadastro de poços, na sua maioria poços cacimbas (98\%), as cargas hidráulicas apresentaram variação expressiva, de 746,7 m (BM - 26) a 790,4 m (BM - 09), e média de 764,8 m (ANEXO B).

No mapa potenciométrico natural da região de Biritiba-Mirim (DESENHO 01), observam-se linhas potenciométricas variando de dez em dez metros, nas cotas de 750, 760, 770, e $780 \mathrm{~m}$. O padrão das curvas potenciométricas é, em geral, concordante com as variações da topografia. As curvas indicam fluxos locais em direção às drenagens que descem pelas encostas da bacia. Regionalmente, as águas subterrâneas fluem na direção do rio Biritiba-Mirim.

$\mathrm{Na}$ planície de inundação, ao longo do rio Biritiba-Mirim, observam-se os gradientes mais suaves, em torno de $10^{-2} \mathrm{~m} / \mathrm{m}$, enquanto que os gradientes mais abruptos são observados ao longo das encostas, com valores em torno de $10^{-1} \mathrm{~m} / \mathrm{m}$.

\subsubsection{Características físico-químicas}

A obtenção de parâmetros físico-químicos nesta etapa do trabalho tem por objetivo principal caracterizar a qualidade das águas subterrâneas antes do enchimento do reservatório. Os dados poderão ser utilizados na identificação de possíveis modificações na qualidade dessa água, que venham a ocorrer como conseqüência da elevação induzida do nível freático. 
De acordo com BREDEHOEFT et al. (1983) os dados físico-químicos também podem ser utilizados para reforçar o modelo conceitual, auxiliando no estudo da direção do fluxo. Os dados físico-químicos, neste caso, foram utilizados no sentido de caracterizar, sob esse aspecto, a qualidade da água da região, visando subsidiar a avaliação do impacto hidrogeológico.

Para a avaliação da qualidade da água potável, foi observada a Norma de Qualidade da Água para Consumo Humano, estabelecida na Portaria No 1.469 , de 29 de dezembro de 2000 (FUNASA/MS, 2001).

Durante o cadastramento de pontos de água subterrânea, foram efetuadas medições de condutividade elétrica in situ em amostras de água de poços, para se obter um panorama da qualidade das águas do aqüífero livre na área estudada, por meio do conhecimento das condições de salinidade.

A Condutividade Elétrica (CE) está relacionada com o teor de sais dissolvidos (TSD) por intermédio da relação TSD = 2/3 CE (LOGAN, 1965); de acordo com o padrão de aceitação de consumo, a água potável deve apresentar valores de TSD inferiores a $1000 \mathrm{mg} / \mathrm{L}$ (FUNASA/MS, 2001).

$\mathrm{Na}$ área de estudo foram amostrados 62 poços cacimbas, que apresentaram valores médios de condutividade elétrica em torno de $121 \mu \mathrm{S} / \mathrm{cm}$ (ANEXO B). Considerando-se a relação proposta por LOGAN (op. cit.), os resultados obtidos indicam que as águas subterrâneas do aqüífero livre apresentam, sob esse aspecto, uma boa qualidade.

O valor máximo de $280 \mu \mathrm{S} / \mathrm{cm}$ foi encontrado no poço $\mathrm{BM}-19$, enquanto que o mínimo, de $61 \mu \mathrm{S} / \mathrm{cm}$, observou-se no $\mathrm{BM}-22$. Os poços $\mathrm{BM}-05, \mathrm{BM}-28$ e BM - 62 apresentaram valores extremos isolados, entre 430 e $660 \mu \mathrm{S} / \mathrm{cm}$ (ANEXO B). No primeiro caso, o poço está localizado ao lado do canil e de um tanque, enquanto que os BM - 28 e BM - 62 encontram-se abandonados, sendo considerados como fatos isolados, relacionados a problemas locais dessas captações.

$\mathrm{O}$ pH apresentou valor médio de 6,7, com máximas de 8,5 no BM - 62 e 11 no BM - 28, sendo este superior ao recomendado pelo padrão de potabilidade (FUNASA/MS, 2001). Estes dois poços apresentaram, também, os valores extremos de condutividade elétrica (ANEXO B). 
A temperatura da água manteve-se na média de $19,2{ }^{\circ} \mathrm{C}$, enquanto que a temperatura média do ar durante o cadastramento foi de $18,9^{\circ} \mathrm{C}$.

\subsection{Balanço hídrico}

As entradas e saídas de água do sistema e as direções de fluxo são parte integrante do modelo conceitual. A recarga resulta da precipitação, da irrigação, a partir de corpos d'água superficiais e dos sistemas de tratamento sanitário. Enquanto que as saídas de água do sistema devem-se à evapotranspiração, aos corpos d'água superficiais e aos poços de abastecimento.

O balanço hídrico na bacia de contribuição do reservatório de Biritib-Mirim, envolveu a quantificação dos seguintes componentes do processo de transferência de água:

a) recarga por meio da precipitação, da irrigação e dos corpos d'água superficiais (como por exemplo lagos e açudes);

b) descargas por meio das nascentes, rios e evapotranspiração.

Para o cálculo do balanço hídrico foi utilizada a equação sugerida por TUCCI (1993):

$V_{t}-V_{o}=(P-Q-E T) \Delta_{t}$

Onde:

$V_{t}=$ Armazenamento de umidade da bacia no final do intervalo de tempo $\Delta_{t}\left[\mathrm{~L}^{3}\right]$

$V_{o}=$ Armazenamento de umidade da bacia no início do intervalo de tempo $\Delta_{t}$ $\left[\mathrm{L}^{3}\right]$

$V_{t}-V_{o}=V_{\Delta t}=$ Variação do armazenamento da bacia no período de tempo considerado $\Delta_{t}\left[\mathrm{~L}^{3}\right]$

$\Delta_{t}=$ Intervalo de tempo [T]

$P=$ Precipitação no período $\left[\mathrm{L}^{3} / \mathrm{T}\right]$

$Q=$ Vazão no período $\left[\mathrm{L}^{3} / \mathrm{T}\right]$

$E T=$ Evapotranspiração no período $\left[\mathrm{L}^{3} / \mathrm{T}\right]$ 
Para a obtenção do volume total de cada um dos componentes envolvidos no balanço hídrico, foi considerada a área total da bacia de contribuição do reservatório, de $72,38 \mathrm{~km}^{2}$, que corresponde à bacia de contribuição do rio Biritiba-Mirim, no trecho que se estende da barragem até o remanso do reservatório (DESENHO 01). Com essa finalidade foram utilizados os dados de precipitação $(1.501 \mathrm{~mm} / \mathrm{ano})$ e de evapotranspiração potencial $(701 \mathrm{~mm} / \mathrm{ano})$. A vazão média utilizada $\left(2,0 \mathrm{~m}^{3} / \mathrm{s}\right)$ foi quantificada pela SONDOTÉCNICA (1996) para uma área de contribuição de $75 \mathrm{~km}^{2}$, sendo re-calculada para a área da bacia de contribuição do reservatório (TABELA 7.1).

TABELA 7.1 - Volumes utilizados para o cálculo do balanço hídrico.

\begin{tabular}{cccc}
\hline Área de contribuição & Precipitação $(P)$ & Vazão média (Q) & Evapotranspiração (ET) \\
\hline $72.380 .000 \mathrm{~m}^{2}$ & $108.649 .618 \mathrm{~m}^{3} / \mathrm{ano}$ & $60.868 .685 \mathrm{~m}^{3} / \mathrm{ano}$ & $50.760 .094 \mathrm{~m}^{3} / \mathrm{ano}$ \\
\hline
\end{tabular}

${ }^{1}$ Fonte: SONDOTÉCNICA (1996).

Aplicando os dados à Equação 7.1., obtém-se:

$$
\begin{aligned}
& V_{\Delta t}=\left(108.649 .618 \mathrm{~m}^{3} / \mathrm{ano}-60.868 .685 \mathrm{~m}^{3} / \mathrm{ano}-50.760 .094 \mathrm{~m}^{3} / \mathrm{ano}\right) \times 1 \text { ano } \\
& V_{\Delta t}=-2.979 .161 \mathrm{~m}^{3}
\end{aligned}
$$

Em períodos de observação de longa duração, a variação do armazenamento no tempo $\left(V_{\Delta t}\right)$ pode ser considerado como um valor desprezível. O resultado de 2.979.161 $\mathrm{m}^{3}$ obtido indica um erro de aproximadamente $2,7 \%$ no cálculo.

Do valor total escoado $\left(60.868 .685 \mathrm{~m}^{3} / \mathrm{ano}\right)$, parte corresponde ao escoamento superficial, que ocorre na superfície do solo e nos seus canais, parte ao escoamento hipodérmico, que ocorre na zona de raízes da cobertura vegetal e, o restante, ao escoamento subterrâneo, que representa a contribuição para o aqüifero. No geral, a soma do escoamento superficial e subterrâneo correspondem à maior porção do total escoado.

Para separar a parcela correspondente a cada tipo de fluxo foi utilizado o hidrograma, no qual se relaciona a vazão com o tempo. A parcela de escoamento superficial pode ser identificada no hidrograma, por métodos gráficos (TUCCI, 1993). A 
análise do hidrograma permite a obtenção da Precipitação Efetiva $\left(P_{e f}\right)$, ou parcela do total precipitado que gera o escoamento superficial, para cada evento, por intermédio do cálculo expresso na equação 7.2.

$$
P_{e f}=Q_{\text {sup }} x f
$$

Na qual:

$P_{e f}=$ Precipitação Efetiva ou Escoamento Superficial ( $\left.\mathrm{mm}\right)$ [L].

$Q_{\text {sup }}=$ Escoamento Superficial $\left(\mathrm{m}^{3} / \mathrm{s}\right)$ (obtido a partir do hidrograma) $\left[\mathrm{L}^{3} / \mathrm{T}\right]$

$f=$ fator de conversão de $\mathrm{m}^{3} / \mathrm{s}$ para $\mathrm{mm}$ [adim.]

Neste caso, foi calculado o fator de conversão de $\mathrm{m}^{3} / \mathrm{s}$ para $\mathrm{mm}$ diários, para acompanhar as medidas da precipitação diária:

$$
\begin{aligned}
f & =10^{-3} \cdot A\left(\mathrm{~km}^{2}\right) \cdot 10^{6} /(60 \cdot 60 \cdot 24) \\
& =10^{-3} \cdot 91 \mathrm{~km}^{2} \cdot 10^{6} /(60 \cdot 60 \cdot 24) \\
& =1,05
\end{aligned}
$$

Sendo,

$A$ = área da bacia de contribuição da estação fluviométrica Biritiba-Mirim (prefixo 3E-OO7) $\left[\mathrm{L}^{2}\right]$

A partir da relação entre a Precipitação Efetiva $\left(P_{e f}\right)$ e a Precipitação Total $(P)$, obtém-se o coeficiente de escoamento $(C)$ (TABELA 7.2):

$$
C=P_{e f} / P
$$

A duração da precipitação e sua intensidade são fatores fundamentais no comportamento do hidrograma. Segundo TUCCI (1993), precipitações de alta intensidade podem provocar o aumento do escoamento superficial, em curto espaço de tempo, enquanto que precipitações menos intensas mas com maior duração tendem a aumentar o escoamento subterrâneo, em detrimento do superficial, estabilizando o pico de

vazão. 
TABELA 7.2 - Cálculo do Coeficiente de Escoamento $(C)$ da bacia de drenagem dos rios Biritiba-Mirim/Biritiba Açu

\begin{tabular}{|c|c|c|c|c|c|c|c|}
\hline \multirow[t]{2}{*}{$\begin{array}{l}\text { Mês do evento } \\
\text { (precipitação) }\end{array}$} & \multirow[t]{2}{*}{$\begin{array}{l}\text { Precipitação }^{1} \\
(P)(\mathrm{mm})\end{array}$} & \multicolumn{2}{|c|}{$\begin{array}{l}\mathrm{N}^{0} \text { de dias de } \\
\text { Precipitação }\end{array}$} & \multirow{2}{*}{$\begin{array}{c}\text { Vazão Total } \\
\text { do rio }{ }^{2} \\
(Q)\left(\mathrm{m}^{3} / \mathrm{s}\right)\end{array}$} & \multirow{2}{*}{$\begin{array}{l}\text { Escoamento } \\
\text { Superficial } \\
\left(Q_{\text {sup }}\right)\left(\mathrm{m}^{3} / \mathrm{s}\right)\end{array}$} & \multirow{2}{*}{$\begin{array}{c}\text { Precipitação } \\
\text { Efetiva }^{3} \\
\left(P_{e f}\right)(\mathrm{mm})\end{array}$} & \multirow{2}{*}{$\begin{array}{l}\text { Coeficiente de } \\
\text { Escoamento } \\
\text { (C) }\end{array}$} \\
\hline & & Total & $>0,5 \mathrm{~mm} / \mathrm{d}$ & & & & \\
\hline Janeiro & 67,3 & 6 & 2 & 39,7 & 19,0 & 18,0 & 0,27 \\
\hline Janeiro & 32,8 & 3 & 3 & 32,4 & 10,6 & 10,1 & 0,31 \\
\hline Abril & 24,6 & 4 & 2 & 24,2 & 6,6 & 6,2 & 0,25 \\
\hline Abril & 137,7 & 11 & 6 & 59,5 & 21,4 & 20,3 & 0,14 \\
\hline Julho & 73,8 & 7 & 3 & 37,0 & 15,2 & 14,5 & 0,20 \\
\hline Agosto & 81,6 & 8 & 6 & 30,0 & 11,96 & 11,4 & 0,14 \\
\hline Setembro & 87,1 & 9 & 7 & 37,4 & 13,8 & 13,1 & 0,15 \\
\hline Outubro & 53,1 & 6 & 4 & 27,8 & 12,2 & 11,6 & 0,21 \\
\hline Dezembro & 31,8 & 6 & 4 & 18,6 & 6,8 & 6,43 & 0,20 \\
\hline Média & - & - & - & - & - & - & 0,21 \\
\hline
\end{tabular}

${ }^{1}$ Cálculo realizado com dados de precipitação coletados em 1976, no posto pluviométrico de Sertãozinho (código E3-231), localizado no município de Biritiba-Mirim (DAEE, 2000).

${ }^{2}$ Cálculo realizado com dados de vazão coletados em 1976, na estação fluviométrica Biritiba-Mirim (prefixo 3E-OO7) que abrange a bacia de drenagem dos rios Biritiba Mirim/Biritiba Açu, de 91 km² (DAEE, 2000).

${ }^{3}$ Escoamento superficial.

De acordo com o cálculo, o Coeficiente de Escoamento $(C)$ médio da bacia é de 0,21 , ou seja, $21 \%$ da precipitação escoa superficialmente. A partir dos dados de precipitação pluviométrica indicados (ver TABELA 7.1), foi calculada a precipitação efetiva da área da bacia em $22.816 .420 \mathrm{~m}^{3} / a n o$.

A partir da vazão de $60.868 .685 \mathrm{~m}^{3} / a n o$ (ver TABELA 7.1), considerando que $22.816 .420 \mathrm{~m}^{3} / a n o$ correspondem ao escoamento superficial, e que o escoamento subsuperficial que ocorre na zona de raízes é desprezível, foi calculado o escoamento subterrâneo em $38.052 .265 \mathrm{~m}^{3} / a n o$ ( $35 \%$ da precipitação total).

Portanto, o balanço hídrico resultante é:

\begin{tabular}{lc} 
Precipitação $(P)$ & $108.649 .618 \mathrm{~m}^{3} / \mathrm{ano}$ \\
Evapotranspiração $(E T)$ & $-50.760 .094 \mathrm{~m}^{3} / \mathrm{ano}$ \\
Escoamento Superficial $\left(P_{e f}\right)$ & $-22.816 .420 \mathrm{~m}^{3} / \mathrm{ano}$ \\
Escoamento Subterrâneo & $-38.052 .265 \mathrm{~m}^{3} / \mathrm{ano}$ \\
\hline Total & $-2.979 .161 \mathrm{~m}^{3} / \mathrm{ano}$ \\
Erro & $-2,7 \%$
\end{tabular}


Segundo o DAEE (1975), 23\% da precipitação total anual estaria contribuindo para as descargas dos rios da região da Grande São Paulo. De acordo com estimativas de MENEGASSE-VELÁSQUEZ (1996), esse valor representa $25 \%$. Nesse processo, a recarga proveniente da área de afloramento do embasamento cristalino alterado seria transferida para os depósitos sedimentares e posteriormente para as drenagens (ROCHA et al., 1989).

No entanto, além dos componentes do processo de transferência de água, já citados, a área apresenta um importante fator de recarga artificial: a irrigação. Os agricultores utilizam a água coletada em pequenos reservatórios (açudes), localizados em afluentes do rio Biritiba-Mirim, construídos especialmente com o propósito de suprir água para a irrigação das suas lavouras.

AGENA et al. (2000) elaboraram um trabalho de avaliação hidráulica dos sistemas de irrigação por aspersão convencional, envolvendo a caracterização do seu desempenho, na região do Alto Tietê.

Os resultados do trabalho indicaram uma taxa mínima de aplicação de água no solo de $16,8 \mathrm{~mm} / \mathrm{d}(0,0168 \mathrm{~m} / \mathrm{d})$, considerando que as terras são irrigadas durante o período aproximado de 1 hora por dia, nos meses de deficiência hídrica.

Por outro lado, o método para o cálculo do balanço hídrico edafológico, desenvolvido por Thornthwaite e Mather em 1955, foi utilizado por SENTELHAS et al. (1999) para definir as necessidades hídricas das culturas para a região de Mogi das Cruzes e, conseqüentemente, as épocas de irrigação durante o ano. Os resultados obtidos para a região de Mogi das Cruzes indicaram deficiência hídrica nos meses de abril, maio, junho, julho, agosto e setembro.

Considerando-se que $21 \%$ da precipitação pluviométrica escoa superficialmente, que $35 \%$ compõe o escoamento subterrâneo e que $41 \%$ das terras da bacia de drenagem do rio Biritiba-Mirim apresentam ocupação rural densa, foi calculado um valor aproximado para recarga mínima do aqüífero, por meio da Equação 7.4. 


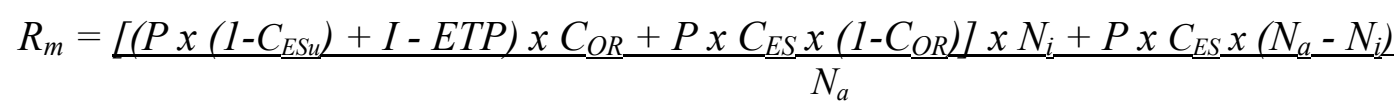

Sendo:

$R_{m}=$ Recarga mínima do aqüífero [L/T]

$P=$ Precipitação pluviométrica [L/T]

$C_{E s u}=$ Coeficiente de escoamento superficial (escoamento superficial/precipitação) [adim.]

$I \quad=$ Taxa de irrigação $[\mathrm{L} / \mathrm{T}]$

ETP = Evapotranspiração potencial [L/T]

$C_{O R}=$ Coeficiente de ocupação rural (área rural/área total) [adim.]

$E S$ = Escoamento subterrâneo [L/T]

$C_{E S}=$ Coeficiente de escoamento subterrâneo (escoamento subterrâneo/precipitação) [adim.]

$N_{i}=$ Número de dias com irrigação [T]

$N_{a}=$ Número de dias do ano [T]

$R_{m}=\{[(0,0041 \mathrm{~m} / \mathrm{d} \times 0,79+0,0168 \mathrm{~m} / \mathrm{d}-0,00192 \mathrm{~m} / \mathrm{d}) \times 0,41+(0,0041 \mathrm{~m} / \mathrm{d} \times 0,35 \times 0,59)] \times$ $183 \mathrm{~d}+0,0041 \mathrm{~m} / \mathrm{d} \times 0,35 \times 182 \mathrm{~d} / 365 \mathrm{~d}$

$$
R_{m}=0,00485 \mathrm{~m} / \mathrm{d}
$$

O valor de recarga mínimo aproximado do aqüífero, é de 0,00485 m/d. 


\section{ELABORAÇÃO DO MODELO MATEMÁTICO}

O modelo matemático de fluxo subterrâneo fundamenta-se na definição do modelo hidrogeológico da área em estudo. Este modelo hidrogeológico, denominado de modelo conceitual, é elaborado com base nas características físicas da área, e permite definir o domínio do modelo, o tipo de aqüífero a ser modelado, as condições iniciais e de contorno e as entradas e saídas de água do sistema.

A elaboração do modelo numérico inclui o projeto do modelo, a definição das condições de contorno, a seleção inicial de valores dos parâmetros do aqüífero e dos estresses hidrológicos, a seleção da condição inicial do sistema e do tempo de simulação, e a definição da malha.

\subsection{Projeto do modelo}

Do ponto de vista das dimensões espaciais, o modelo utilizado foi um modelo bidimensional, que assume o ponto de vista do aqüifero. Simulações de modelos bidimensionais classificam os aqüíferos em quatro categorias: confinados, confinados drenantes, livres e mistos (ANDERSON \& WOESSNER, 1992).

Com base no modelo hidrogeológico da área estudada, e considerando as condições limites e as solicitações impostas ao meio, foi adotado conceitualmente o comportamento de aqüifero livre. Nesse caso, foram assumidas as hipóteses de Dupuit (CUSTÓDIO \& LLAMAS, 1996).

No caso da área de estudo, o sistema aqüífero, considerado isotrópico e heterogêneo, estaria sujeito à recarga pela infiltração de águas meteóricas e da irrigação, à influência do sistema de drenagem das águas superficiais, e à descarga pela evapotranspiração atuando a profundidades variáveis. 


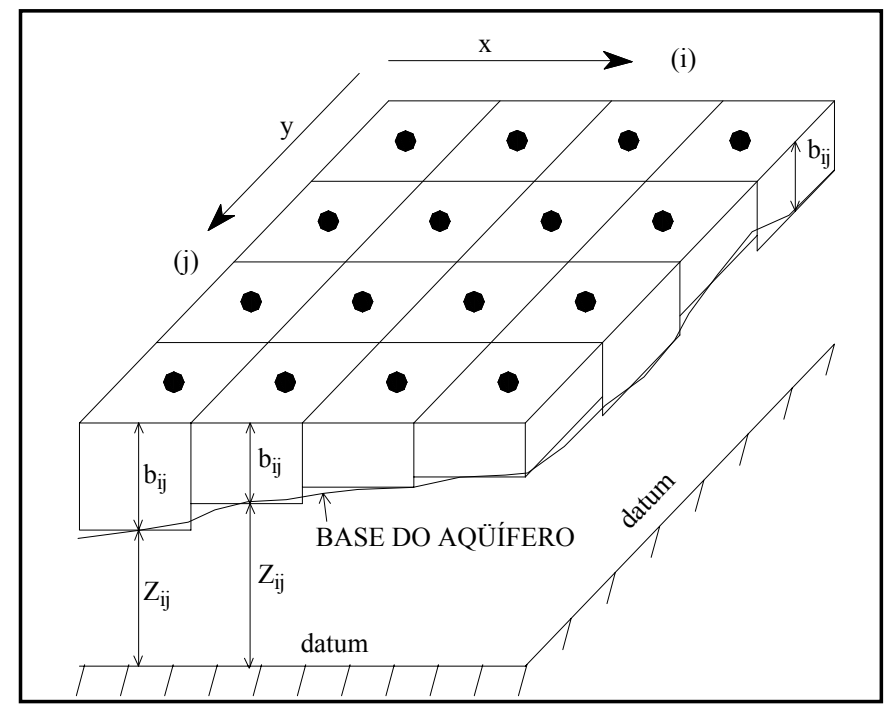

\begin{tabular}{|ll} 
Condutividade hidráulica & $(\mathrm{Kx})_{\mathrm{ij}}$ e $(\mathrm{Ky})_{\mathrm{ij}}$ \\
Espessura do aqüífero & $\left(\mathrm{b}_{\mathrm{ij}}\right)$ \\
Cota da base do aqüífero & $\left(\mathrm{Z}_{\mathrm{ij}}\right)$ \\
Coeficiente de armazenamento & $\left(\mathrm{S}_{\mathrm{ij}}\right)$
\end{tabular}

Fonte: modificado de ANDERSON \& WOESSNER (1992).

FIGURA 8.1 - Malha de células centralizadas utilizada na representação do modelo bidimensional do aqüífero livre

\subsection{Definição das condições de contorno}

A partir do modelo conceitual foi possível identificar as áreas de recarga $\mathrm{e}$ descarga da região, e as feições que afetam hidraulicamente o sistema, tais como sumidouros e fontes de água.

No caso da bacia de drenagem do rio Biritiba-Mirim, os limites da área foram estabelecidos em concordância com a distribuição das condições naturais de contorno existentes. Divisores de águas regionais, encontrados nas áreas topograficamente elevadas, representaram limites de fluxo nulo.

Segundo ANDERSON \& WOESSNER (1992), uma bacia hidrográfica pode ser representada por um modelo bidimensional com limites de fluxo nulo ao longo do seu perímetro, representando os divisores de água. Entretanto, nos problemas de fluxo 
permanente, requere-se pelo menos um nó com carga hidráulica específica para dar ao modelo uma elevação de referência, a partir da qual calculará os valores restantes.

A partir do modelo conceitual foi realizada a seguinte representação matemática das condições de contorno da bacia:

a) limite hidráulico, com fluxo específico (nulo) nas células de contorno, representando os divisores d'água da bacia (FIGURA 8.2);

b) limite físico, com nível d'água específico nas células do rio Biritiba-Mirim, representando o nível d'água do rio (FIGURA 8.2).

Na bacia estudada, o rio Biritiba-Mirim atravessa a região. O curso d'água foi representado como limite com carga hidráulica dependente (FIGURA 8.2). Nesse caso, a condição de carga hidráulica dependente (drenança) foi utilizada para simular a penetração parcial do rio. Esta opção requer a especificação da cota do nível d'água do rio $\left(h_{\text {fonte }}\right)$, oferecendo, assim, referências de carga hidráulica para a solução do modelo.

A rocha impermeável forma o limite inferior do sistema modelado. De acordo com FREEZE \& WITHERSPOON, (1967) e NEUMAN \& WITHERSPOON (1969), duas ordens de magnitude no valor da condutividade hidráulica são suficientes para justificar a escolha de um corpo impermeável. Este tipo de contraste na condutividade hidráulica ocasionaria refração das linhas de fluxo, de forma que na camada de maior condutividade este seria considerado essencialmente horizontal.

As condições de contorno, descritas a seguir, foram utilizadas para a elaboração do modelo matemático, no seu processo de calibração e simulação e encontram-se detalhadas em ANDERSON \& WOESSNER (1992). 


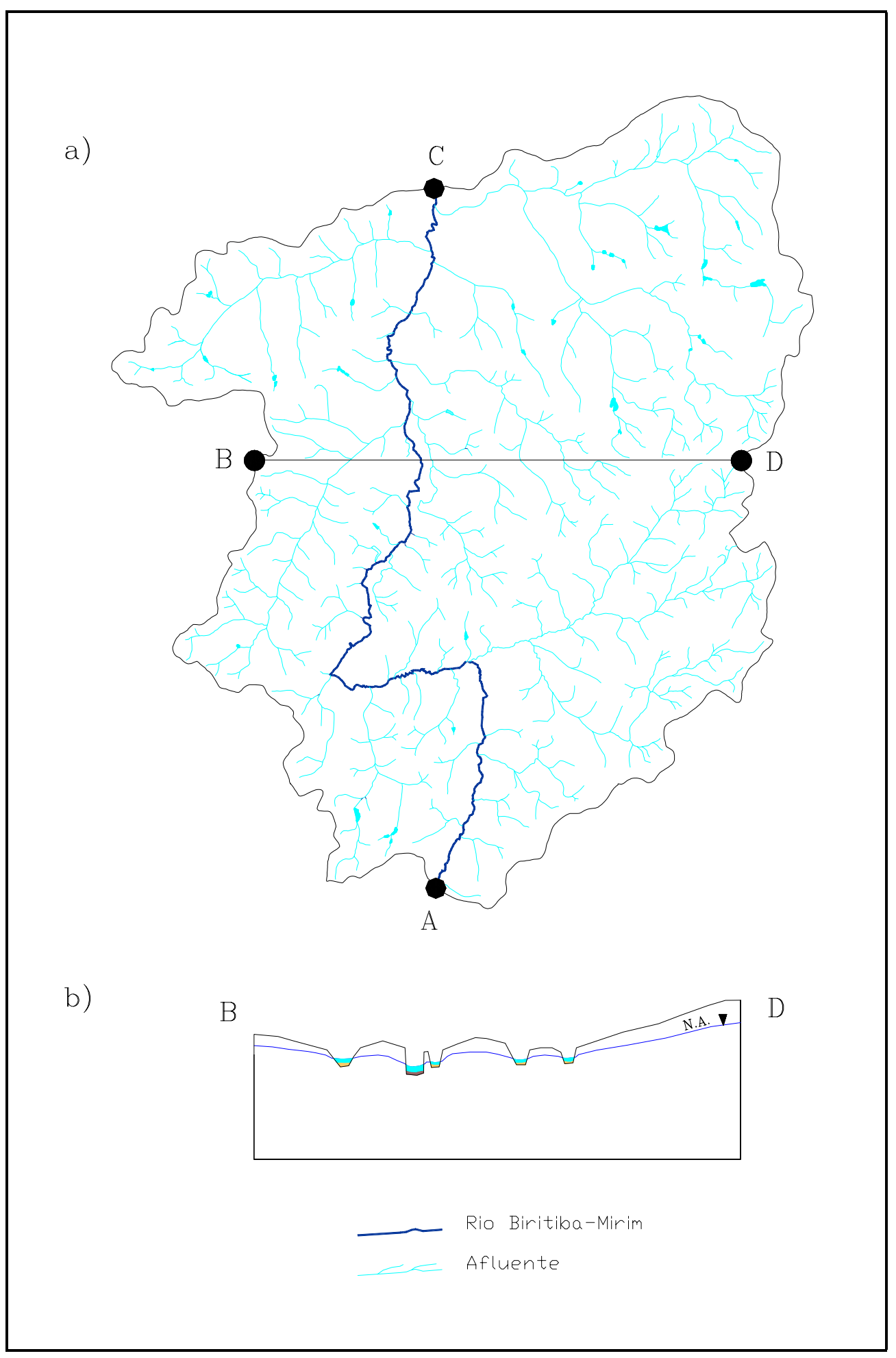

FIGURA 8.2 - Condições de contorno para a bacia de drenagem do rio BiritibaMirim

a) Fluxo nulo ao longo do perímetro da bacia, ABCDA. Carga hidráulica constante nos limites representados pelos pontos $A$ e $C$, aos quais designou-se o valor da cota do nível de água do rio Biritiba-Mirim no respectivo ponto.

b) Para representar o rio utilizou-se a condição de drenança pela base, que possibilitou simular um curso d'água parcialmente penetrante. 


\subsubsection{Limites sem fluxo ou fluxo nulo}

O limite sem fluxo ocorre quando o fluxo através do mesmo é zero e pode representar uma rocha impermeável, uma zona de falhas impermeáveis ou divisores de água.

O limite sem fluxo é simulado designando, para a célula inativa mais próxima, valores de condutividade hidráulica (ou transmissividade) iguais a zero.

\subsubsection{Limite de fluxo dependente da carga hidráulica}

O fluxo neste tipo de limite matemático depende da diferença entre a carga hidráulica calculada pelo modelo num lado do limite e aquela especificada no outro lado. Em modelos de diferenças finitas o fluxo é calculado para toda a célula.

A drenança $L[L]$ de ou para um rio, lago ou reservatório pode ser simulada utilizando-se condições de fluxo dependente. O fluxo resultante da percolação é calculado por:

$$
\begin{aligned}
& L=\frac{Q_{L}}{A}=K_{z}^{\prime}\left(\frac{h_{\text {fonte }}-h}{b^{\prime}}\right) \\
& \text { e } \quad A=w l
\end{aligned}
$$

Sendo:

$Q_{L}=$ fluxo percolado ou drenança $\left[\mathrm{L}^{3} / \mathrm{T}\right]$

$K_{z}^{\prime}=$ condutividade hidráulica da interface que separa o aqüífero da fonte (ex. sedimento do leito do rio) [L/T]

$h_{\text {fonte }}=$ nível de água no reservatório de origem (por exemplo um rio) [L]

$h$ = carga hidráulica no aqüífero adjacente à fonte [L]

$b^{\prime}=$ espessura da interface $[\mathrm{L}]$

$A$ = área da interface $\left[\mathrm{L}^{2}\right]$

$w=$ largura da interface $[\mathrm{L}]$

$l \quad=$ comprimento da interface $[\mathrm{L}]$ 
O fluxo em direção aos drenos também é calculado por intermédio da drenança, quando $h$ é maior que $h_{\text {fonte }}$ (a elevação do dreno), e igual a zero se $h$ é menor. Os parâmetros $K_{z}^{\prime}$ e $b^{\prime}$ representam as propriedades da interface entre o dreno e o aqüífero.

A evapotranspiração do aqüífero também pode ser considerada um limite de fluxo dependente, considerando que o fluxo (ou perda do aqüífero) é proporcional à profundidade do nível d'água subterrânea.

\subsubsection{Limites com carga hidráulica específica}

Corpos de água superficiais que penetram totalmente no aqüífero (por exemplo alguns lagos), são representados por limites com carga hidráulica específica.

Limites com carga hidráulica específica são simulados fazendo com que o valor da carga hidráulica do nó seja igual ao valor do nível de água conhecido. No caso de lagos, o limite é descrito como carga hidráulica constante.

O limite com nível especificado representa um suprimento de água inesgotável. O sistema pode ser recarregado ou descarregar água nesse limite sem alterar o valor do nível de água especificado para o nó.

\subsection{Definição da condição inicial do sistema}

A condição inicial do sistema diz respeito à carga hidráulica do aqüífero no início da simulação. Esta informação compõe um dos limites do sistema quando se considera o fator tempo.

No processo de calibração, as informações foram processadas em condição de fluxo permanente, ou seja, sem considerar o fator tempo. Procurou-se, nesta fase, atingir o equilíbrio do sistema, de modo que as cargas hidráulicas simuladas se aproximassem às observadas em campo. Nesse caso, foi utilizada a condição inicial estática, ou seja, carga hidráulica constante no tempo e no espaço.

A distribuição das cargas hidráulicas calculadas a partir da simulação em fluxo permanente, durante a calibração do modelo, foi, então, utilizada como condição inicial do sistema para a simulação do enchimento do reservatório de Biritiba-Mirim e na 
verificação do modelo. No caso, foi utilizada a condição inicial dinâmica, ou seja, carga hidráulica constante no tempo e espacialmente variável.

A utilização das cargas hidráulicas resultantes da calibração assegura que a potenciometria inicial seja consistente com as informações hidrológicas e parâmetros de entrada do modelo na fase de simulação (FRANKE et al., 1987).

\subsection{Seleção inicial dos valores de parâmetros e estresses hidrológicos}

Para dar-se inicio ao processo de modelagem, foram definidos valores iniciais para os parâmetros e estresses que afetam o aqüífero. Os estresses hidrológicos são os fatores responsáveis pela recarga (como é o caso da precipitação), ou descarga do sistema (como é o caso da evapotranspiração).

Descrevem-se, a seguir, os cálculos realizados para a obtenção dos valores preliminares utilizados como dados de entrada no processo de modelagem (de acordo com o indicado em McDONALD \& HARBAUGH, 1988).

\subsubsection{Rio Biritiba-Mirim}

No modelo numérico, o rio Biritiba-Mirim foi representado como limite de fluxo dependente da carga hidráulica. O programa MODFLOW simula o fluxo de água entre o aqüífero e o reservatório superficial (rio) pó intermédio da condutância do leito do rio $\left(C_{\text {rio }}\right)\left[\mathrm{L}^{2} / \mathrm{T}\right]$, que é calculada por:

$$
C_{\text {rio }}=k_{r} L w / b
$$

Sendo:

$L=$ o comprimento do canal $[L]$

$w=$ largura do canal $[\mathrm{L}]$

$b=$ espessura dos sedimentos que compõem o leito [L]

$k_{r}=$ condutividade hidráulica vertical dos sedimentos que compõem o leito do rio $[\mathrm{L} / \mathrm{T}]$ 
Foi assumida uma condutância de $3 L$ [L] para o rio principal, este valor foi atribuído aos arcos (segmentos) que representam o curso d'água.

Estimou-se a profundidade média de lâmina d'água do rio Biritiba-Mirim, de $\quad 0,5$ $\mathrm{m}$, enquanto que a sua cota altimétrica foi obtida a partir da base topográfica. Estes atributos foram designados aos nós que conectam os arcos (FIGURA 8.3).

A vazão de água que flui entre o rio e o aqüifero $\left(Q_{\text {rio }}\right)\left[\mathrm{L}^{3} / \mathrm{T}\right]$ é calculada pelo programa por meio da seguinte equação:

$$
\begin{aligned}
& Q_{\text {rio }}=C_{\text {rio }}\left(H_{\text {rio }}-h\right) \quad h>R_{\text {leito }} \\
& Q_{\text {rio }}=C_{\text {rio }}\left(h-H_{\text {rio }}\right) \quad h \leq R_{\text {leito }}
\end{aligned}
$$

Sendo:

$C_{r i o}=$ condutância do leito do rio $\left[\mathrm{L}^{2} / \mathrm{T}\right]$

$H_{r i o}=$ cota do nível de água do rio [L]

$h$ = cota do nível de água do aqüífero [L]

$R_{\text {leito }}=$ cota topográfica da base dos sedimentos que compõem o leito do rio [L]

\subsubsection{Afluentes do rio Biritiba-Mirim}

No modelo numérico, os córregos (ou drenos) foram representados como limites de fluxo dependente da carga hidráulica. O programa simula o fluxo de água entre o aqüífero e o reservatório superficial (dreno) por intermédio da condutividade do seu leito, como no caso do rio principal, só que aqui, a percolação do córrego para o aqüífero não é permitida.

Quando a carga hidráulica do aqüifero $(h)$ é inferior à elevação do leito do córrego $(d)$, a descarga é igual a zero, mas quando a carga hidráulica é superior, determinada vazão é drenada em função da condutividade do córrego:

$$
\begin{array}{ll}
Q_{c o ́ r}=0 & \text { para } h \leq d \\
Q_{c o ́ r}=C_{c o ́}(h-d) & \text { para } h>d
\end{array}
$$


Sendo:

$Q_{c o ́}=$ vazão drenada do aqüifero $\left[\mathrm{L}^{3} / T\right]$

$C_{c o ́ r}=$ condutividade do leito do córrego $\left[\mathrm{L}^{2} / \mathrm{T}\right]$

$h$ = carga hidráulica do aqüífero [L]

$d$ = elevação topográfica do leito do córrego [L]

As nascentes, locais onde a água subterrânea intercepta a superfície do terreno, também foram simuladas como córregos, com representação da cota topográfica no ponto de emergência de água, como dado de elevação do dreno. Esta interpretação foi também utilizada quando a configuração geomorfológica do local indicava uma predisposição à formação de nascentes, já que, de acordo com a interpretação do modelo, o fluxo do dreno ocorre apenas quando o nível de água subterrânea se encontra acima da superfície do terreno.

Foi assumida uma condutância de $1 L(\mathrm{~m})$ para os córregos. Este valor foi atribuído aos arcos que representam os cursos d'água. A cota de elevação do dreno foi definida a partir da base topográfica, sendo um atributo dos nós que conectam os arcos (FIGURA 8.3).

\subsubsection{Evapotranspiração}

A evapotranspiração $(E T)$ ocorre quando o nível freático está próximo à superfície topográfica. Nos casos em que o nível freático calculado pelo modelo $(h)$ é igual ao nível topográfico $\left(h_{t}\right)$, é assumido para cada célula o valor máximo de $E T$ $\left(R_{E T M}\right)$. A evapotranspiração deixa de ocorrer quando a carga hidráulica se encontra abaixo do valor designado como "profundidade máxima de atuação" $(d)$. É assumida uma variação linear entre estes dois extremos. O volume $E T\left(Q_{E T}\right)\left[L^{3}\right]$ é obtido a partir do seguinte cálculo:

$$
\begin{array}{ll}
Q_{E T}=Q_{E T M}=R_{E T M} \Delta x \Delta y & \text { para } h>h_{t} \\
Q_{E T}=0 \quad \text { para } & h<d \\
Q_{E T}=Q_{E T M}\left[h-\left(h_{t}-d\right)\right] / d & \text { para }\left(h_{t}-d\right) \leq h \leq h_{t}
\end{array}
$$




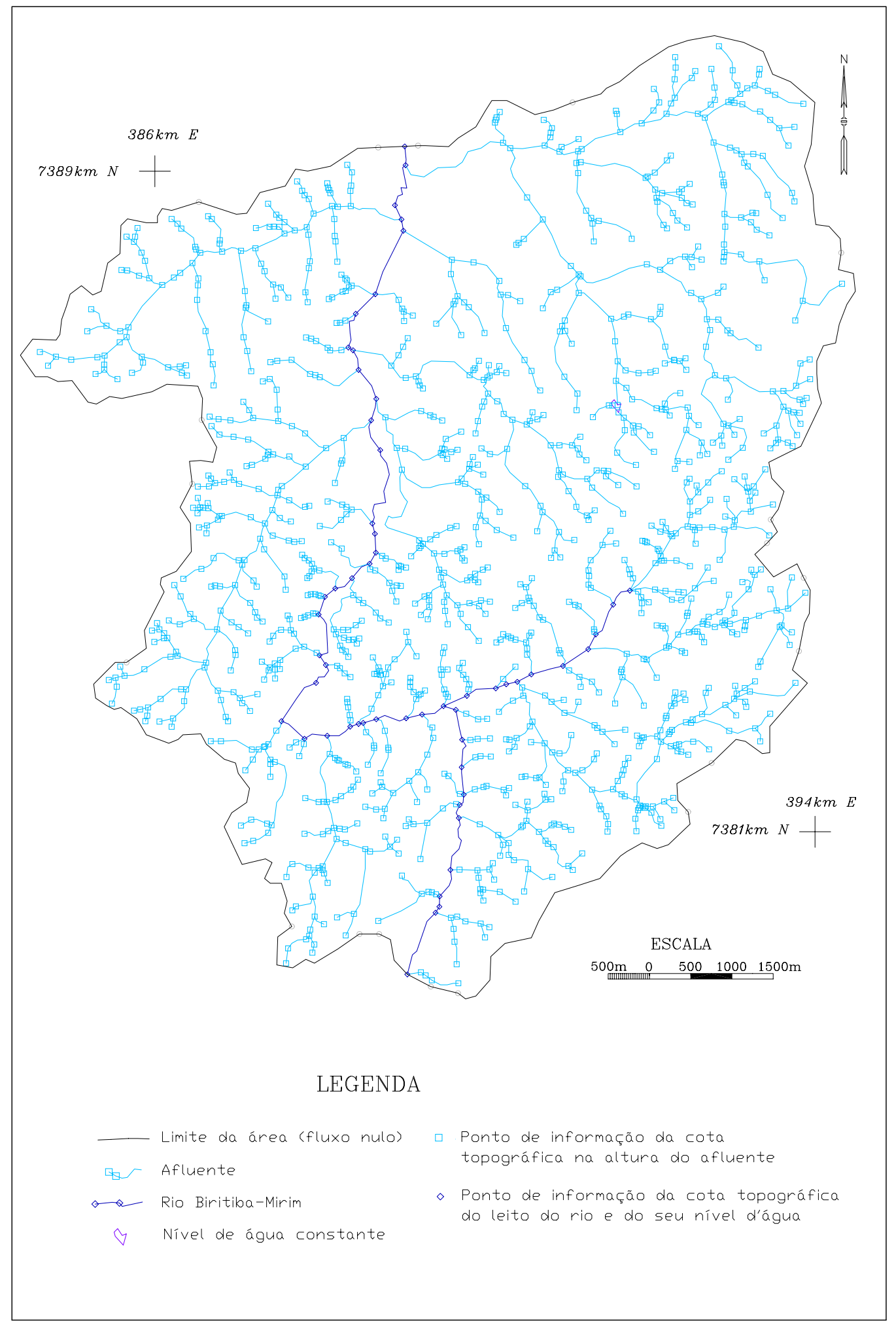

FIGURA 8.3 - Plano de Informação (coverage) fontes/sumidouros, do módulo MAP, da interface GMS (ECGL, 1996) 
Sendo,

$Q_{E T}=$ volume de água evapotranspirada $\left[\mathrm{L}^{3}\right]$

$Q_{E T M}=$ volume máximo possível de água evapotranspirada $\left[\mathrm{L}^{3}\right]$

$R_{E T M}=$ valor máximo de evapotranspiração [L]

$h$ = nível freático calculado pelo modelo [L]

$h_{t} \quad=$ nível topográfico $[\mathrm{L}]$

$d$ = profundidade máxima de atuação, a partir da qual não ocorre evapotranspiração [L]

$\Delta x=$ distância na direção $x[\mathrm{~L}]$

$\Delta y=$ distância na direção $y[\mathrm{~L}]$

Foi utilizado o valor de $1,9210^{-3} \mathrm{~m} / \mathrm{d}$, estimado durante a elaboração do modelo conceitual, como a evapotranspiração máxima da área. A profundidade limite do efeito da evapotranspiração foi determinada em $1 \mathrm{~m}$. A elevação foi obtida a partir da utilização da base topográfica, que foi utilizada para a criação de zonas hipsométricas definidas pelos seguintes intervalos de nível: 750 m, 755 m, 775 m, 800 m, 850 m e 900 m (FIGURA 8.4).

\subsubsection{Recarga}

A recarga do aqüífero considerada pelo termo "fonte" (source), representa o volume de água que entra no sistema pela precipitação pluviométrica. No caso da bacia de drenagem do rio Biritiba-Mirim, este valor foi estimado durante a elaboração do modelo conceitual, resultando em valor de $4,8510^{-3} \mathrm{~m} / \mathrm{d}$. 


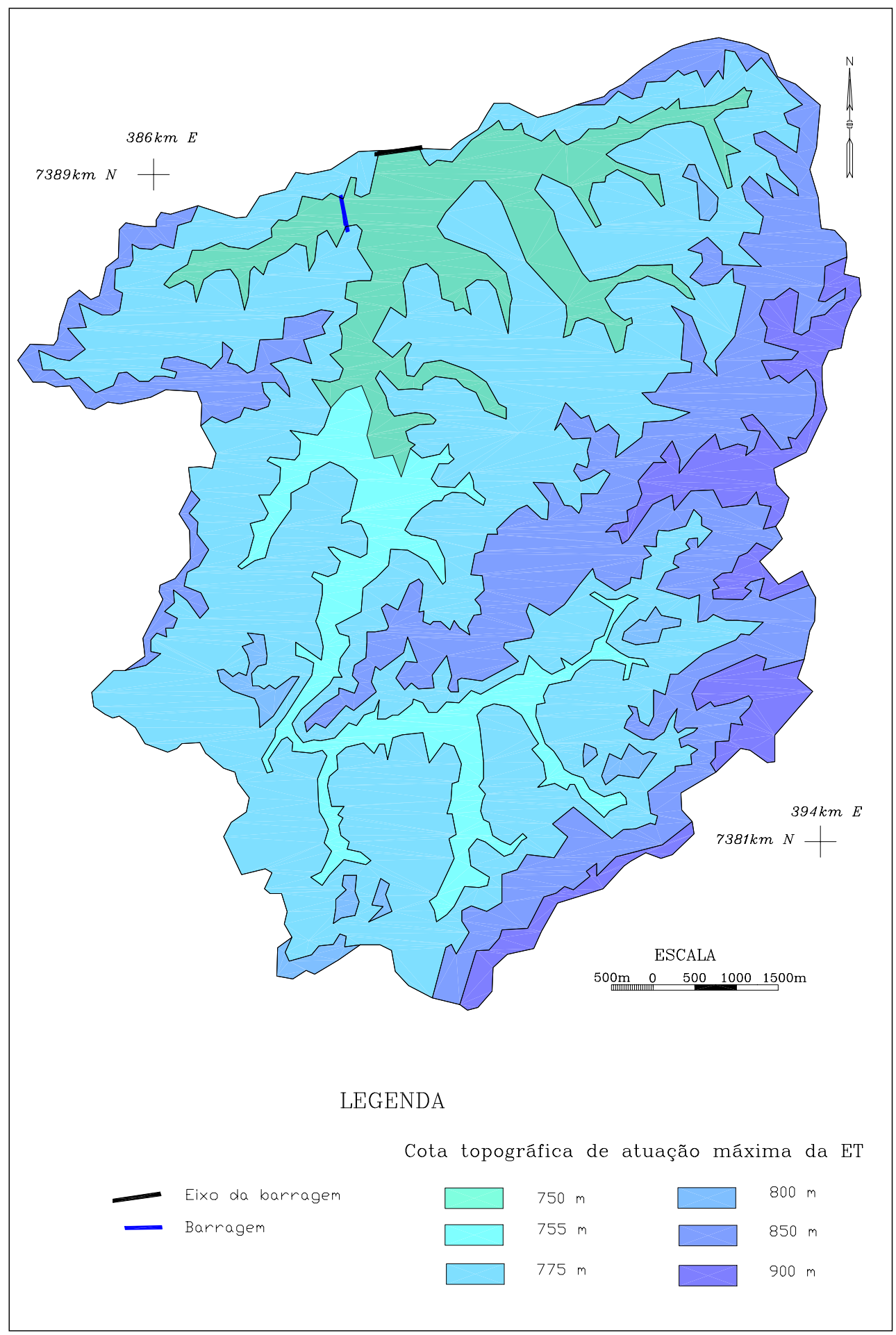

FIGURA 8.4 - Plano de Informação (coverage) aéreo, do módulo $M A P$, da interface GMS (ECGL, 1996) 


\subsubsection{Transmissividade}

A transmissividade foi estimada a partir de valores de condutividade hidráulica obtidos na literatura, em HEATH (1983), e de valores estimados da espessura do aqüífero, previamente descritos na elaboração do modelo conceitual.

A condutividade hidráulica, capacidade do aqüífero de transmitir água, é integrada na dimensão vertical do aqüífero para obter as características médias de transmissão de água (DOMÉNICO \& SCHWARTZ, 1997):

$T=k b$

Sendo:

$T=$ transmissividade $\left[\mathrm{L}^{2} / \mathrm{T}\right]$

$k=$ condutividade hidráulica $[\mathrm{L} / \mathrm{T}]$

$b=$ espessura do aqüífero [L]

No caso da área de estudo, foram assumidos valores iniciais de transmissividade de $1,5 \mathrm{~m}^{2} / \mathrm{d}$ nas áreas de Colinas, Morrotes, Morrotes Paralelos, Morros, Serras e Montanhas, até $40 \mathrm{~m}^{2} / \mathrm{d}$ nas planícies fluviais que circundam esta região (FIGURA 8.5), considerando-se que: 


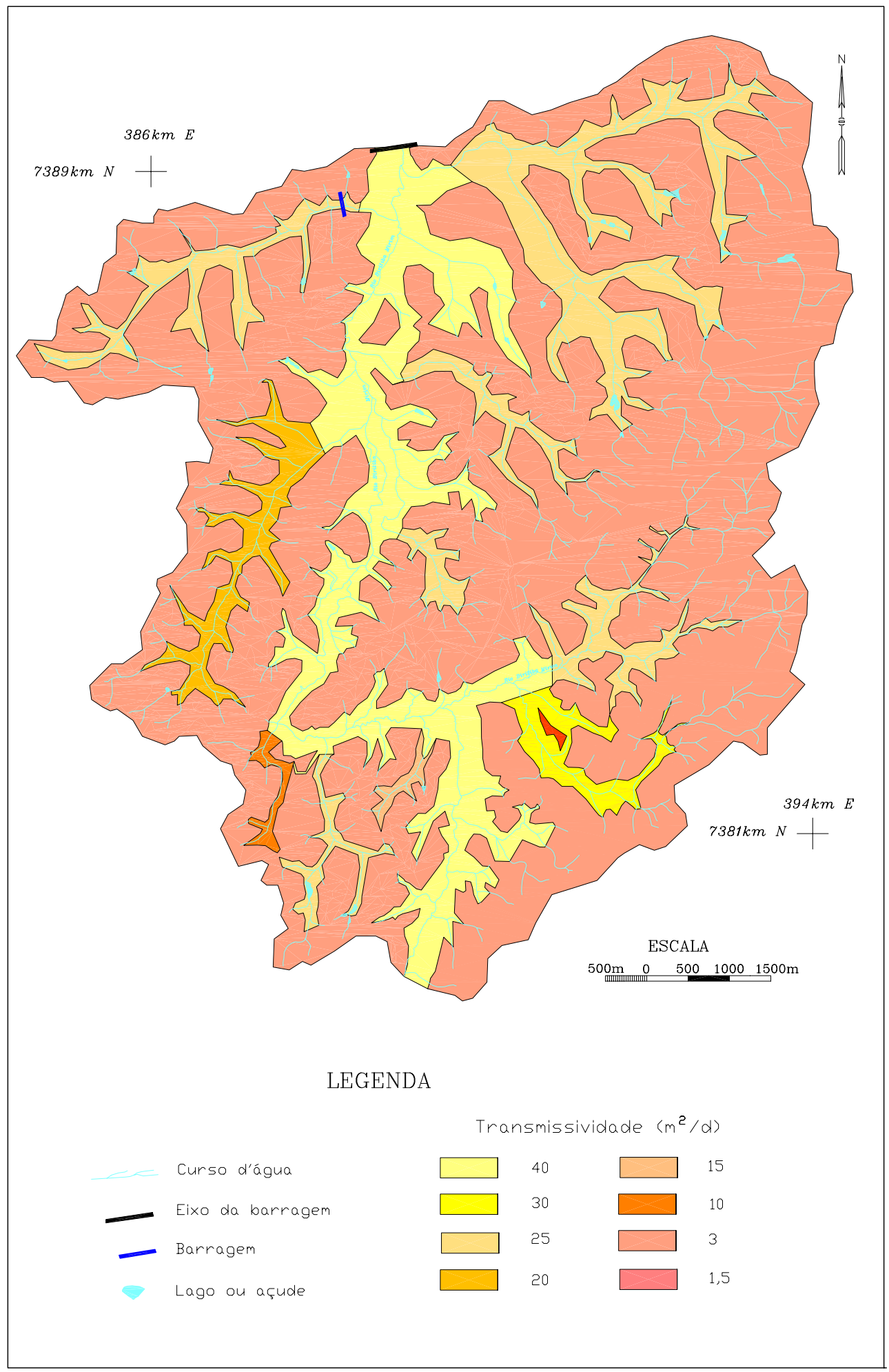

FIGURA 8.5 - Plano de Informação (coverage) da camada (layer), do módulo MAP, da interface GMS (ECGL, 1996) 
a) a espessura média do aqüífero (b) varia de 5 a $20 \mathrm{~m}$; e

b) a condutividade hidráulica $(k)$ considerada varia de $10^{-1} \mathrm{~m} / \mathrm{d}$ a $10^{1} \mathrm{~m} / \mathrm{d}$, para material predominante variando de areia siltosa a areia grossa (HEATH, 1983).

AGENA et al. (2000) realizaram o estudo da parametrização físico hídrica dos solos das colinas médias da região, utilizados para o cultivo de hortaliças e irrigados pelo sistema de aspersão convencional. De acordo com essa pesquisa, à profundidade de 0,42 a $0,83 \mathrm{~m}$, a permeabilidade dos solos varia de 7 a $82 \mathrm{~m} / \mathrm{d}$.

\subsubsection{Seleção do tempo}

No processo de calibração, as informações foram processadas em condição de fluxo permanente. Procurou-se atingir o equilíbrio do sistema proposto, considerando as cargas hidráulicas observadas em campo.

A simulação do enchimento do reservatório de Biritiba-Mirim também foi realizada em condição de fluxo permanente, permitindo avaliar as cargas hidráulicas finais, resultantes após o sistema atingir o equilíbrio.

\subsection{Transferência dos dados para o modelo matemático MODFLOW}

No modelo numérico, o problema, que se apresenta num domínio contínuo, é representado num domínio discretizado, que consiste num conjuntos de nós associados a células de diferenças finitas.

Para a aplicação do modelo, foi considerada a bacia de contribuição do reservatório de Biritiba-Mirim, com uma superfície de $72,38 \mathrm{~km}^{2}$.

O modelo conceitual e o modelo numérico selecionado determinaram o tipo e as dimensões da malha:

a) no que se refere ao tipo de malha, optou-se pela representação de células centradas, nas quais os parâmetros são assinalados para o centro de cada célula; 
b) no que se refere às dimensões da malha, definiu-se que a utilização de uma camada de células no eixo horizontal seria adequada para representar a unidade aqüífera previamente definida no modelo conceitual.

A área, selecionada de acordo com o divisor d'água regional, foi dividida em uma malha constituída por 120 linhas e 104 colunas, com células de $100 \mathrm{~m}$ na direção $x$, $100 \mathrm{~m}$ na direção $y$ e $200 \mathrm{~m}$ na direção $z$. Durante a simulação, a espessura do aqüífero foi especificada indiretamente, por intermédio do valor da transmissividade, que é igual à condutividade hidráulica $(k)$ vezes a espessura $(b)$ da camada $(\Delta z)$.

A malha retangular foi recortada de forma a acompanhar o contorno irregular da bacia de drenagem, resultando no total de 7.246 células ativas, correspondendo a uma superfície total modelada de $72,46 \mathrm{~km}^{2}$.

$\mathrm{Na}$ utilização da malha de células centradas, baseada no modelo de diferenças finitas, a designação de parâmetros ocorre de modo que os limites de fluxo coincidem com o limite da célula, o que não representa de forma precisa os limites da área. No entanto, a transferência das informações do módulo MAP para o MODFLOW permitiu recortar a malha de forma a acompanhar o contorno irregular da bacia de drenagem, minimizando, assim, o número de nós inativos (localizados fora dos limites da área modelada).

O modelo de diferenças finitas calcula a cota do nível d'água para cada nó. Este valor corresponde à média para a célula. Na malha de células centradas, utilizada para discretizar a área de estudo, as propriedades do aqüífero e estresses hidráulicos são extrapolados à célula que rodeia o nó.

$\mathrm{Na}$ transferência dos parâmetros para a malha, no caso dos modelos bidimensionais, são necessárias médias para cada parâmetro, que são obtidas indiretamente, pelo cálculo da média de valores pontuais. As propriedades do aqüífero são, então, atribuídas à unidade hidrogeológica identificada durante a elaboração do modelo conceitual. A malha é dividida em zonas, de forma que um conjunto de nós apresente propriedades aqüíferas similares, de acordo com a extensão da unidade hidrogeológica.

Para o cálculo da condutância dos cursos d'água superficiais, o módulo MAP da interface utilizada, Groundwater Modeling System - GMS, da ECGL (1996), permite 
atribuir o valor de condutância por unidade de comprimento para o arco que representa o rio ou córrego conforme a Eq. 8.2.

Quando o programa transfere estas informações para a malha (FIGURA 8.6), multiplica automaticamente o valor da condutância pelo comprimento do arco que intersecta a célula, inserindo, assim, a condutância real do segmento. Os valores dos parâmetros aplicados aos nós (por exemplo a elevação do leito do rio e seu nível d'água), são interpolados ao longo do arco (média linear), sendo designado, para cada célula, o valor obtido na metade do segmento intersectado.

No caso de parâmetros como a recarga e a evapotranspiração, o centro de cada célula é comparado com o polígono no qual se encontra sobreposto, adquirindo então o atributo do mesmo. Quando uma única célula se sobrepõe a mais de um polígono, o valor designado para a mesma é resultante da agregação do atributo definido para cada um desses polígonos.

No caso dos parâmetros restantes (por exemplo a transmissividade), o centro de cada célula é comparado com o polígono no qual se encontra sobreposto, adquirindo, então, o atributo do mesmo. Uma vez especificada a transmissividade para cada célula, o programa utiliza a média harmônica para calcular a transmissividade entre os nós (ECGL, 1996). 


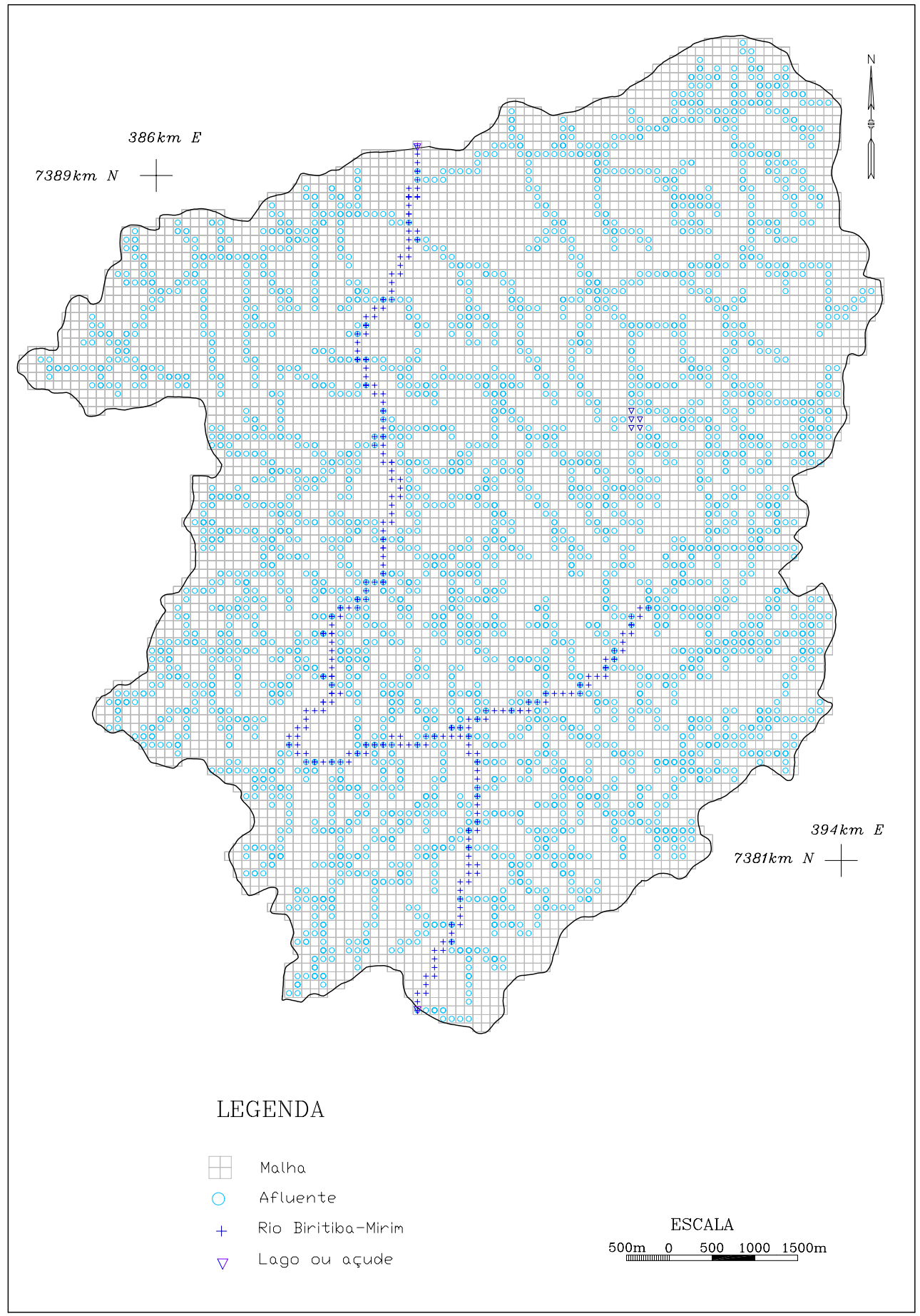

FIGURA 8.6 - Plano de Informação (coverage) fontes/sumidouros (modelo conceitual), transferido para o modelo numérico 


\section{CALIBRAÇÃO DO MODELO MATEMÁTICO}

A proposta da calibração é estabelecer um modelo que possa reproduzir as medidas de nível d'água e direção de fluxo observados em campo.

$\mathrm{Na}$ tentativa de se reproduzir, em laboratório, cargas hidráulicas e fluxos subterrâneos correlacionáveis às situações que ocorrem em escala real, foram reavaliados os valores iniciais dos parâmetros. Nesta etapa, observou-se a influência e consistência dos parâmetros de entrada e procederam-se as alterações necessárias, de forma a se obter o melhor ajuste às condições potenciométricas iniciais.

A obtenção de parâmetros que possibilitassem a calibração resultou por meio do ajuste manual dos parâmetros e dos estresses que afetam o aqüífero, pelo processo de ajuste por tentativas e erros. O ajuste destes parâmetros foi efetuado com a utilização do módulo MAP (SIG) do programa Groundwater Modeling System - GMS (ECGL, 1996). Posteriormente, os dados foram transferidos para o módulo MODFLOW e testados. O processo foi repetido até a obtenção de resultado satisfatório (FIGURA 9.1), atingido, no caso, quando a carga hidráulica resultante da simulação apresentou erro médio absoluto $(M A E)$ inferior a $1 \mathrm{~m}$, em relação à carga hidráulica obtida nos poços cadastrados em campo, e a percentagem de resíduo foi inferior a $5 \%$.

Descrevem-se, a seguir, os valores finais utilizados para a calibração do modelo:

1) Rio Biritiba-Mirim: o rio Biritiba-Mirim foi representado como limite de fluxo dependente da carga hidráulica, com condutância final de $5 L(\mathrm{~m})$. A profundidade da lâmina d'água do rio Biritiba-Mirim foi definida entre 0,7 e 0,8 $(\mathrm{m})$, com as profundidades maiores ocorrendo na área de descarga da bacia. A cota de elevação do leito do rio foi obtida a partir da base topográfica. Cargas hidráulicas constantes de 739,5 m e 765,3 m foram assumidas para as células que representam, respectivamente, o limite de entrada e de saída do curso d'água da bacia de drenagem considerada;

2) Afluentes do rio Biritiba-Mirim: os córregos foram representados como drenos, com fluxo dependente da carga hidráulica, e assumida uma condutância final variável de 1 a $3 L(\mathrm{~m})$, com ocorrência de valores mais elevados nas áreas de baixada. A cota de elevação do dreno foi definida a partir da base topográfica; 


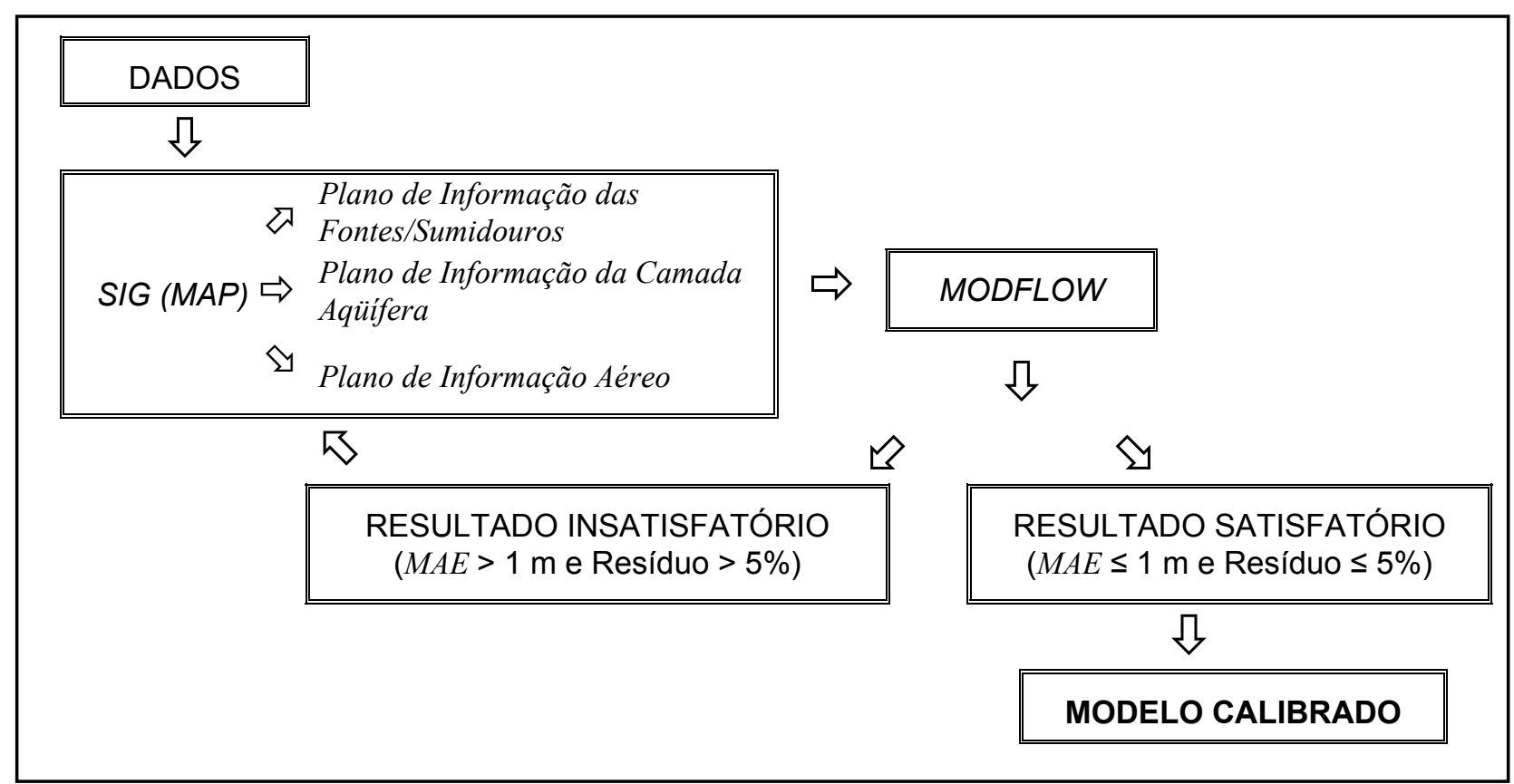

FIGURA 9.1 - Diagrama de decisão utilizado para a calibração do modelo matemático

3) Recarga: para este parâmetro foi utilizado o valor uniforme de $5,510^{-3} \mathrm{~m} / \mathrm{d}$;

4) Transmissividade: os valores de transmissividade apresentaram variação de 1 a $4 \mathrm{~m}^{2} / \mathrm{d}$ nas áreas de Colinas, Morrotes, Morrotes Paralelos, Morros, Serras e Montanhas, e de 10 a $50 \mathrm{~m}^{2} / \mathrm{d}$, nas planícies fluviais que circundam esta região (FIGURA 9.2);

5) Reservatórios Superficiais (lagos, açudes etc.): considerados como corpos d'água com carga hidráulica específica, cujo valor depende da cota topográfica na qual se encontram inseridos;

6) Condição Inicial do Sistema: no processo de calibração as informações foram processadas em regime permanente, ou seja, sem considerar o fator tempo. Determinou-se o valor arbitrário de 720 m como carga hidráulica inicial do sistema, assumindo-se que o efeito da condição inicial não exerce influência na solução (TABELA 9.1). 


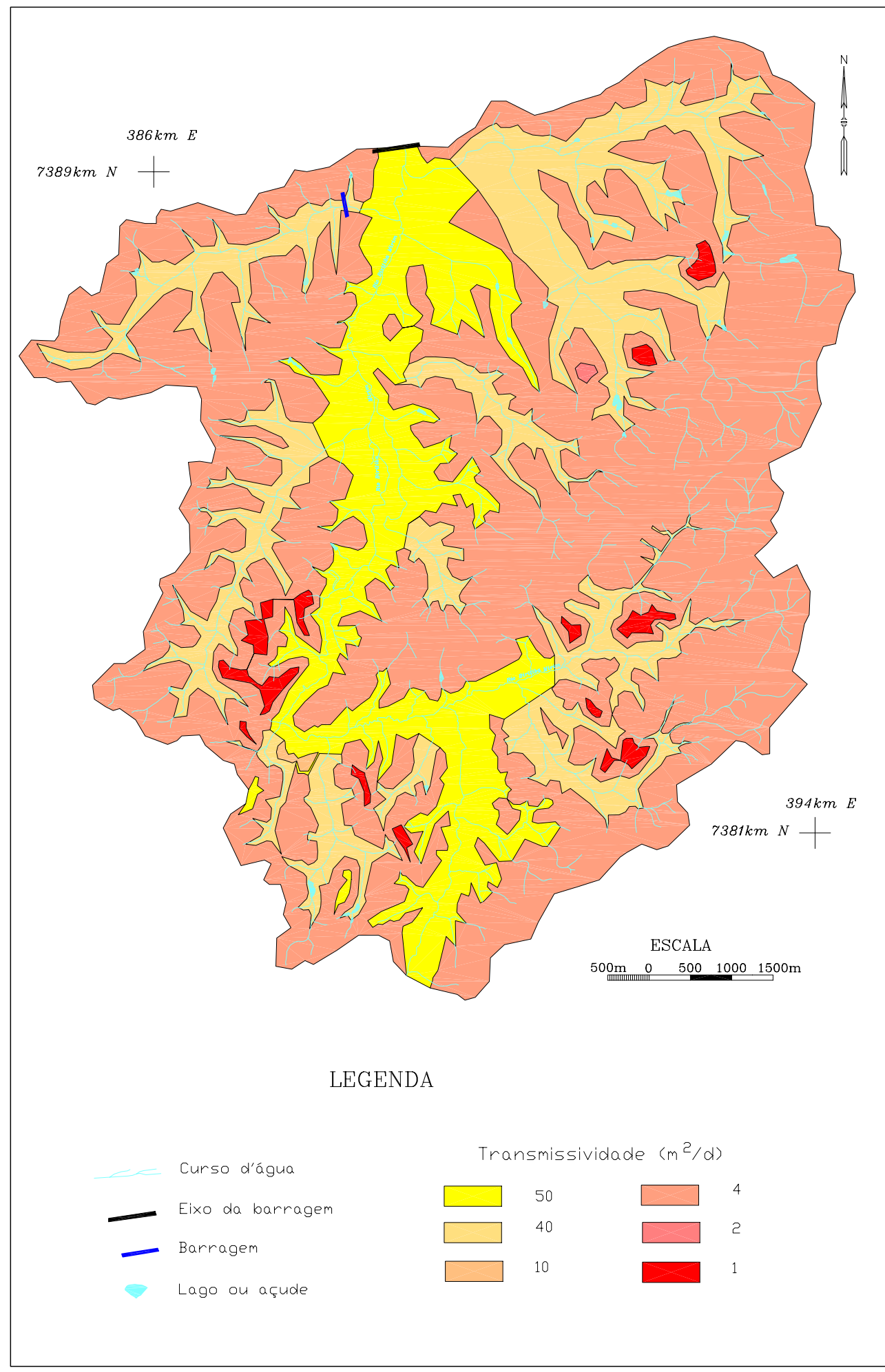

FIGURA 9.2 - Valores finais resultantes da calibração do parâmetro transmissividade. Plano de Informação (coverage) da camada aqüífera 
TABELA 9.1 - Valores finais dos parâmetros do aqüífero que possibilitaram a calibração do modelo matemático.

\begin{tabular}{lc}
\hline \multicolumn{1}{c}{ Parâmetro } & Valor final adotado \\
\hline Transmissividade & 1 a $50 \mathrm{~m}^{2} / \mathrm{d}$ \\
Condutância dos drenos & 1 a $3 \mathrm{~L}(\mathrm{~m})$ \\
Condutância do rio Biritiba-Mirim & $5 \mathrm{~L}(\mathrm{~m})$ \\
Recarga & $5,5 \times 10^{-3} \mathrm{~m} / \mathrm{d}$ \\
Taxa de evapotranspiração & $1,9 \times 10^{-3} \mathrm{~m} / \mathrm{d}$ \\
Elevação onde ocorre a Evapotranspiração Máxima & $750,755,775,800,850$ e $900 \mathrm{~m}$ \\
Profundidade máxima de atuação da & $1 \mathrm{~m}$ \\
evapotranspiração & $720 \mathrm{~m}$ \\
Condição potenciométrica inicial & \\
\hline
\end{tabular}

Para a avaliação da qualidade do modelo calibrado, foram calculados os resíduos, obtidos por meio da comparação entre a carga hidráulica resultante da simulação, e a obtida nos poços cadastrados em campo. Com esse objetivo, foram considerados o erro médio $(M E)$, o erro médio absoluto $(M A E)$, o desvio padrão $(R M S) \mathrm{e}$ a percentagem de resíduo.

O erro médio $(M E)$ foi calculado por meio da seguinte equação:

$M E=1 / n \sum_{t=1}^{n}\left(h_{o b s}-h_{c a l c}\right)_{t}$

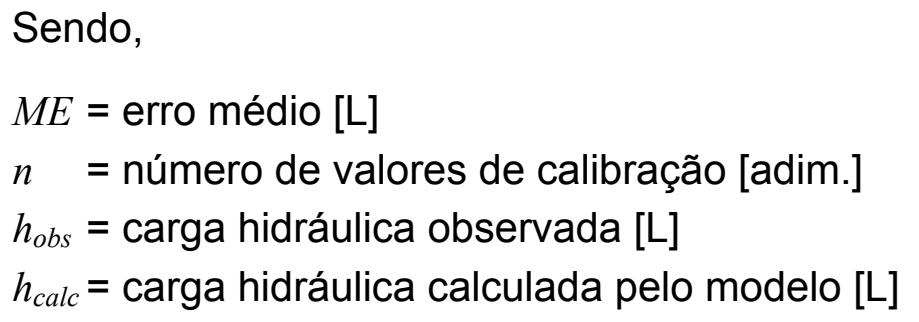

O cálculo do erro médio considera os valores positivos e negativos, enquanto que o erro médio absoluto $(M A E)$ considera o valor absoluto da diferença entre a carga hidráulica observada e calculada. O erro médio absoluto é obtido por:

$$
M A E=1 / n \sum_{t=1}^{n}\left|\left(h_{o b s}-h_{\text {calc }}\right)_{t}\right|
$$


A raiz do erro quadrático médio $(R M S)$, é um dos critérios de calibração mais utilizados, sendo calculado por:

$$
R M S=\left[1 / n \sum_{t=1}^{n}\left(h_{o b s}-h_{\text {calc }}\right)_{t}^{2}\right]^{0,5}
$$

A magnitude de erro aceitável depende da variação da carga hidráulica dentro do domínio do modelo. Alguns autores adotam o critério da percentagem de erro $(\%$ erro $=R M S / \Delta H)$ (IRITANI, 1998), que é relativo à diferença entre as cargas hidráulicas calculadas e observadas em relação à variação total da carga hidráulica no sistema $(\Delta H)$ [L]. Assumiu-se, para fins de calibração, um valor inferior a 5\% como aceitável, devido a elevada amplitude da variação total da carga hidráulica no sistema $(\Delta H)$ [L].

Para a obtenção do valor da carga hidráulica calculada pelo modelo, o mapa potenciométrico resultante do módulo MODFLOW foi transferido para o módulo TIN Triangulated Irregular Network, do programa Groundwater Modeling System - GMS (ECGL, 1996), que permite a interpolação linear dos valores obtidos para cada nó, por meio da triangulação. Uma vez concluída esta etapa, as cargas hidráulicas observadas em campo, nos poços cadastrados, foram comparados com as obtidas no modelo calibrado. A reta, com inclinação de $45^{\circ}$ indica a calibração ideal (FIGURA 9.3), foi obtido um coeficiente de correlação de $97,2 \%$ indicando expressiva relação entre os valores calculados e aqueles obtidos em campo.

A superposição do mapa desenhado em $A u t o C A D$, com o resultado obtido pelo TIN, permitiu a comparação dos dados na localização precisa do poço. A análise estatística desta relação indicou um erro médio $(M E)$ de $-0,1 \mathrm{~m}$, um erro médio absoluto $(M A E)$ de 0,8 m, e desvio padrão de 1,5 m (ANEXO C). Apesar das cargas hidráulicas calculadas pelo modelo não coincidirem precisamente com as observadas em campo (FIGURA 9.3), os valores acompanham aproximadamente a inclinação da reta, levando a considerar o modelo como calibrado. O modelo apresentou uma percentagem de erro de $2,3 \%$. 
Considerando-se, também, as cargas hidráulicas observadas nas sondagens, 0 erro médio $(M E)$ foi $-0,5$, o erro médio absoluto $(M A E)$ 1,0 e o desvio padrão 2,0.

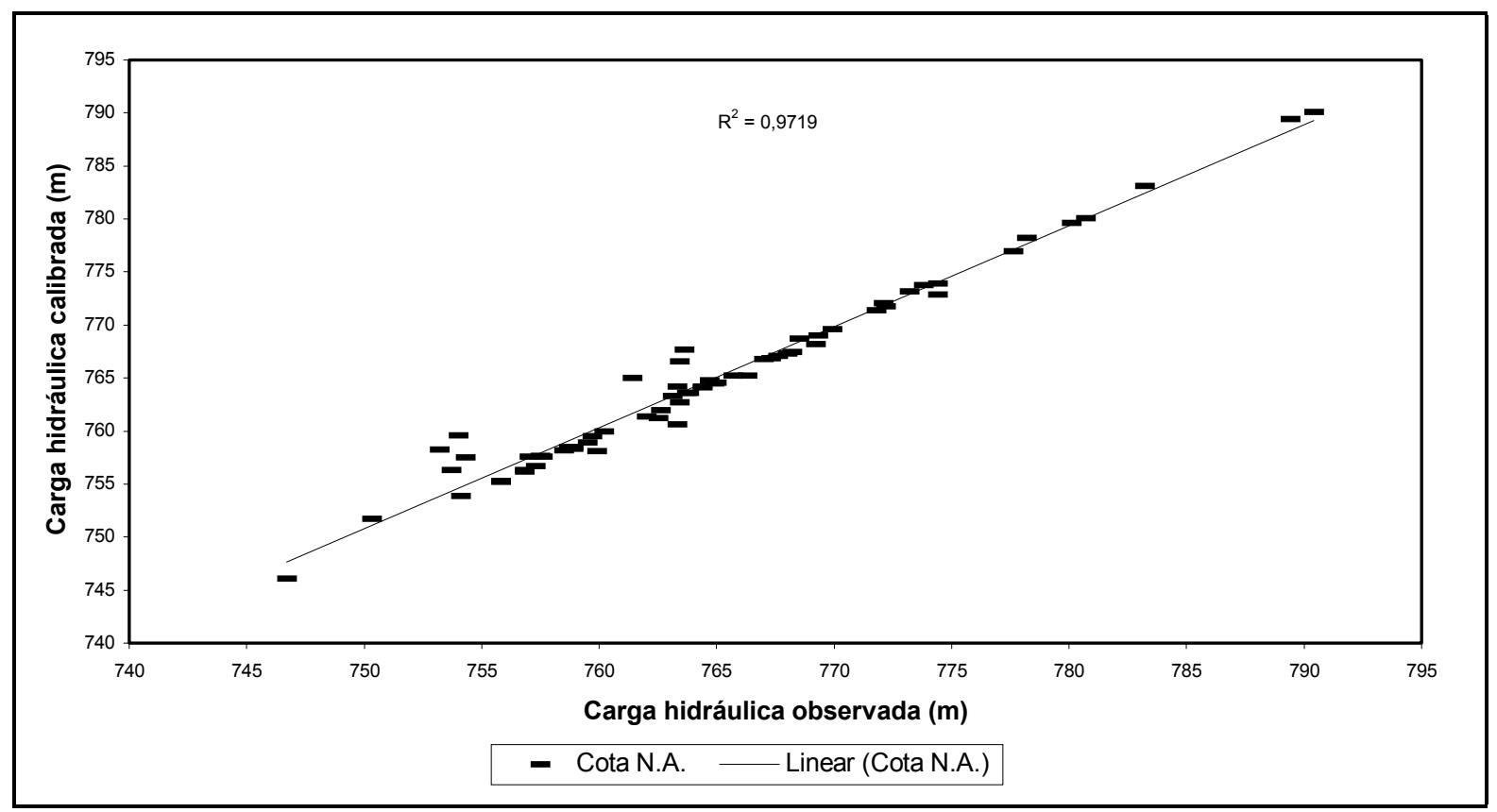

FIGURA 9.3 - Relação entre a carga hidráulica obtida no modelo calibrado e a observada em campo

Em relação ao volume de água que entra e o volume que sai do sistema modelado, os valores são praticamente os mesmos (TABELA 9.2).

Da água que sai do sistema modelado, 0,3\% ocorre por meio de pequenos (reservatórios como lagos e açudes), 78,4\% por córregos e afluentes do rio BiritibaMirim, 7,5\% através do leito do rio principal e 13,8\% por evapotranspiração. A recarga ocorre, principalmente, pela precipitação pluviométrica e artificial (irrigação) (99,8\%).

O escoamento básico total calculado pelo modelo $\left(341.718 \mathrm{~m}^{3} / \mathrm{d}\right)$ apresenta um erro de $-3,8 \%$ em relação ao valor obtido no balanço hídrico da área, referente ao escoamento subterrâneo regular somado à parcela correspondente à irrigação $(354.627$ m³/d). 
TABELA 9.2 - Configuração final do balanço hídrico do modelo calibrado.

\begin{tabular}{lc}
\hline \multicolumn{1}{c}{ Componentes } & $\begin{array}{c}\text { Volume de Água } \\
\text { Acumulado }\left(\mathrm{m}^{3} / \mathrm{d}\right)^{*}\end{array}$ \\
\hline Entradas de água & 138,6 \\
Carga hidráulica constante & $395.310,0$ \\
$\quad$ Recarga & 439,4 \\
Infiltração pelo leito do rio & $395.890,0$ \\
$\quad$ Total & \\
Saídas de água & $1.131,7$ \\
$\quad$ Carga hidráulica constante & $310.330,0$ \\
$\quad$ Drenos & $54.584,0$ \\
$\quad$ Evapotranspiração & $29.708,0$ \\
Infiltração pelo leito do rio & $395.760,0$ \\
Total & 134,5 \\
Entradas - Saídas & $-0,3 \%$ \\
Discrepância & \\
\hline
\end{tabular}

*Para uma área total modelada de $72,46 \mathrm{~km}^{2}$.

A evapotranspiração apresentou valor superior ao inicialmente esperado. Entretanto, os $54.584 \mathrm{~m}^{3} / \mathrm{d}$ obtidos no modelo calibrado, somados aos $139.069 \mathrm{~m}^{3} / \mathrm{d}$, inicialmente descontados no balanço hídrico, perfazem um total de $194.346 \mathrm{~m}^{3} / \mathrm{d}$ (ou $978 \mathrm{~mm} / \mathrm{ano}$ ), que se aproxima do valor de evaporação real calculados para a área por AGENA et al. (2000) (905 mm/ano) e pelo DAEE (1975) (940 mm/ano).

\subsection{Análise de sensibilidade}

A calibração é cercada por incertezas em relação à capacidade de obtenção da exata distribuição espacial e temporal dos valores dos parâmetros relacionados ao problema estudado, além daquelas que envolvem as condições de contorno e estresses. A análise de sensibilidade objetiva estabelecer o efeito das incertezas no processo de calibração do modelo.

Deve ser resaltado que o modelo calibrado aqui apresentado (DESENHO 02) não constitui a única opção de calibração, sendo portanto, fundamental, a avaliação crítica dos parâmetros escolhidos de forma a identificar possíveis variações e justificar os critérios utilizados. 
Dentre os fatores que levaram às incertezas e estimativas realizadas durante o processo de calibração da área da bacia de drenagem do rio Biritiba-Mirim, devem ser destacados:

1) A utilização de base planialtimétrica disponível em escala $1: 10.000$ (EMPLASA, 1982, 1988 e 1996) é um fator fundamental na preparação dos dados de entrada, tais como cota topográfica das nascentes, drenagens, topo e base do aqüifero e superfície e profundidade máxima do efeito da evapotranspiração. No entanto, na área de interesse, a base planialtimétrica existente apresenta alguns problemas de confiabilidade, uma vez que as plantas disponíveis contêm curvas com eqüidistância de $5 \mathrm{~m}$. Além disso, as cotas de poços, sondagens, drenagens e nascentes foram inferidas também a partir destas plantas;

2) A ausência de informações mais precisas a respeito do número, localização e cotas dos canais de drenagem, nas áreas de baixada;

3) A utilização de uma malha de $100 \mathrm{~m} \times 100 \mathrm{~m}$ numa área que se apresenta morfologicamente recortada, com contornos geológicos/geomorfológicos acentuados, resulta em mudanças bruscas entre as transmissividades das áreas de baixada com as das áreas mais elevadas, dificultando maior precisão nas interfaces;

4) A ausência de informações sobre a distribuição dos valores de transmissividade do aqüifero levou à realização de estimativas, inicialmente a partir de dados bibliográficos e, finalmente, definidos durante o processo de calibração do modelo;

5) Os valores de evapotranspiração e da sua profundidade de atuação também foram definidos a partir de dados bibliográficos e ajustados durante a calibração;

6) O ajuste do parâmetro de recarga do aqüífero foi a principal dificuldade durante o processo de calibração. Os valores finais definidos durante a calibração são superiores aos inicialmente estimados no balanço hídrico da área. A opção de incremento de recarga foi fundamental para o ajuste do modelo e encontra-se fundamentada nas características de uso do solo local, já que em $41 \%$ da região é desenvolvida a atividade agrícola, 
na qual a irrigação representa uma prática comum, originando, provavelmente, uma recarga artificial para o aqüífero.

No processo de impacto hidrogeológico de reservatórios, normalmente as áreas mais afetadas são aquelas mais próximas da sua borda. Nesse sentido, as investigações se voltaram prioritariamente para tais áreas. Em conseqüência disso, os divisores e outras áreas mais afastadas da bacia apresentaram lacunas nas informações hidrogeológicas obtidas em campo. Durante a calibração do modelo, os parâmetros foram definidos de acordo com o critério aplicado para o restante da área e ajustados em função da obtenção de uma resposta hidrogeologicamente coerente do sistema.

Foram observadas dificuldades de calibração nas encostas à direita e à esquerda da barragem, onde ocorrem as maiores elevações do nível de descarga do aqüífero, que acentua a influência do reservatório sobre o nível freático. Nessas áreas, a escolha do divisor de água local como limite de fluxo nulo pode dificultar a avaliação sobre a real extensão da influência do reservatório, considerando que esta pode influenciar o próprio divisor.

A avaliação dos parâmetros que mais afetam as cargas hidráulicas calculadas pelo modelo matemático foi efetuada variando-se os valores de condutividade hidráulica, recarga, evapotranspiração e condutância dos drenos, um parâmetro a cada vez, para verificar seu reflexo nos resíduos calculados.

Esse processo, denominado análise de sensibilidade, indicou que o modelo apresenta grande sensibilidade às modificações efetuadas, resultando no aumento, de até três vezes, do resíduo final obtido na calibração, apesar da percentagem de resíduo se manter inferior a 5\% em todos os casos, valor máximo definido para calibração.

Dentre os parâmetros que mais afetaram o modelo, pode ser destacada a recarga, cuja variação em $50 \%$ modifica, em percentagem similar, o escoamento básico do sistema (TABELA 9.3), indicando a sua importância no processo de calibração.

A elevação da evapotranspiração (TABELA 9.3), também afeta, em menor escala, o escoamento básico, elevando a percentagem de resíduo para 8,8\%. 
No que se refere à elevação da permeabilidade, este foi o parâmetro que menos afetou o escoamento básico, elevando, entretanto, o resíduo final obtido na calibração.

A variação da condutância dos drenos apresentou baixa influência no modelo matemático, o que pode ser observado pelo valor do resíduo e pela percentagem do erro no escoamento básico.

TABELA 9.3 - Análise de sensibilidade do modelo matemático construído.

\begin{tabular}{|c|c|c|c|c|c|c|}
\hline Parâmetro & Variação & $M E$ & $M A E$ & $\begin{array}{l}\text { RMS (Desvio } \\
\text { padrão) }\end{array}$ & Resíduo (\%) & $\begin{array}{c}\text { Erro no escoamento } \\
\text { básico }(\%)\end{array}$ \\
\hline Modelo calibrado* & - & $-0,1$ & 0,8 & 1,5 & 2,3 & $-3,64$ \\
\hline Condutividade & $0,5 \mathrm{~K}$ & $-2,4$ & 3,6 & 4,9 & 7,6 & $-7,46$ \\
\hline Hidráulica (K) & $1,5 \mathrm{~K}$ & 0,6 & 2,6 & 3,5 & 5,5 & $-1,57$ \\
\hline \multirow[b]{2}{*}{ Recarga (R) } & $0,5 \mathrm{R}$ & 1,9 & 3,1 & 4,2 & 6,4 & $-53,96$ \\
\hline & $1,5 \mathrm{R}$ & $-2,6$ & 3,9 & 5,4 & 8,4 & 50,64 \\
\hline \multirow[b]{2}{*}{ Evaporação (ET) } & $0,5 \mathrm{ET}$ & $-0,6$ & 2,7 & 3,6 & 5,6 & 3,53 \\
\hline & $1,5 \mathrm{ET}$ & 0,1 & 3,9 & 5,7 & 8,8 & $-9,13$ \\
\hline \multirow{2}{*}{$\begin{array}{c}\text { Condutância do } \\
\text { dreno }\left(\mathrm{C}_{\text {dreno }}\right)\end{array}$} & $0,5 \mathrm{C}_{\text {dreno }}$ & $-1,0$ & 2,9 & 3,8 & 5,8 & $-4,73$ \\
\hline & $1,5 \mathrm{C}_{\text {dreno }}$ & $-0,5$ & 2,6 & 3,5 & 5,5 & $-3,75$ \\
\hline
\end{tabular}

* Indicação do erro obtido no modelo considerado calibrado 


\section{SIMULAÇÃO DO ENCHIMENTO DO RESERVATÓRIO}

O modelo calibrado foi, então, utilizado para a simulação do enchimento do reservatório. Todos os parâmetros foram mantidos de acordo com o modelo inicial, a exceção do lago, que foi acrescentado e teve seus limites ajustados durante a simulação, e da condição inicial do sistema, onde foram utilizadas as cargas hidráulicas resultantes da calibração.

O reservatório foi simulado utilizando células com carga hidráulica específico, tanto ao longo da curva de enchimento, de $757,5 \mathrm{~m}$, quanto no seu interior. O lago, desenhado em SIG por meio do módulo MAP, foi posteriormente transferido para o MODFLOW.

Nos casos em que a curva potenciométrica de 757,5 m não coincidia com a borda do lago, devido ao espaçamento da malha (100 m x $100 \mathrm{~m})$, foi modificada a carga hidráulica especificada nas células adjacentes, de forma a ajustar a curva potenciométrica $757,5 \mathrm{~m}$ com a curva de enchimento (topográfica). Em alguns casos foram modificadas as características das células, de carga hidráulica específica para variável ou vice-versa, conforme a necessidade. O ajuste ocorreu pelo processo de tentativas e erros dentro do módulo MODFLOW. Uma vez atingido o objetivo, a simulação foi dada por concluída. A configuração final das células pode ser observada na FIGURA 10.1.

A partir da simulação do enchimento do reservatório de Biritiba-Mirim, foi obtido o mapa potenciométrico final, com o resultado das modificações máximas a ser provocadas pelo enchimento do lago nos níveis d'água subterrânea.

De acordo com o mapa potenciométrico resultante da simulação (DESENHO 03), as áreas onde os níveis da água subterrânea sofrerão maior influência do reservatório encontram-se restritas às margens do reservatório, sendo a sua largura dependente das características hidrogeológicas do aqüífero.

Pode ser observado que as áreas de maior influência concentram-se basicamente na primeira metade do reservatório, e diminuem no sentido contrário à barragem. 


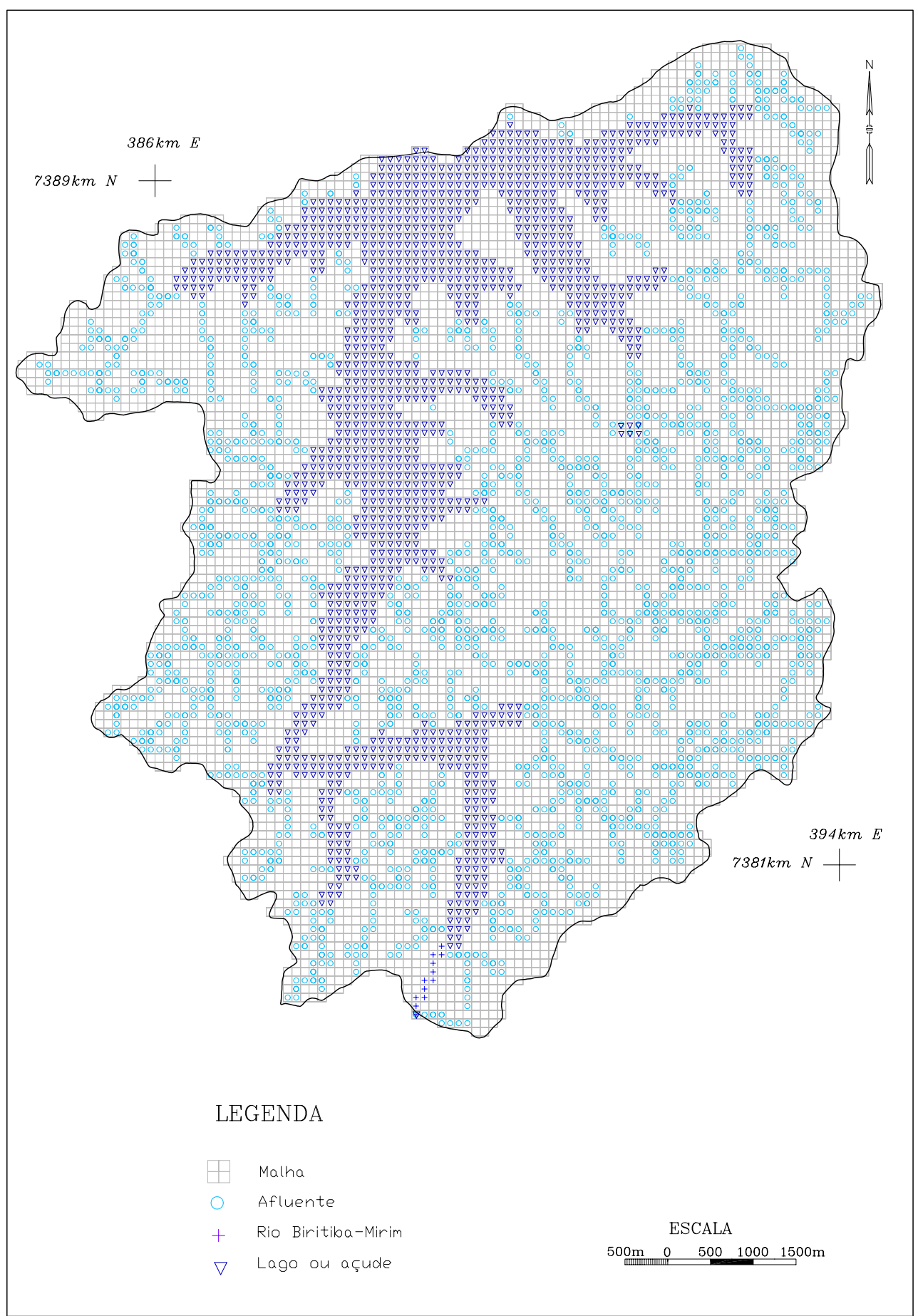

FIGURA 10.1 - Configuração final das células transferidas do Plano de Informação (coverage) fontes/sumidouros para o modelo numérico, na simulação do enchimento do reservatório 
Nas áreas de montante, a topografia pouco acentuada, associada a uma variação baixa de elevação do nível de base do aqüífero, minimizam o efeito do enchimento do reservatório nas suas margens.

A amplitude de elevação do nível de descarga de base do sistema no eixo da barragem é de aproximadamente $18 \mathrm{~m}$, distribuídos numa extensão aproximada de $12 \mathrm{~km}$ ao longo do rio Biritiba-Mirim.

É visível, também, que a influência diminui nas proximidades das drenagens, que funcionam como locais de descarga do aqüífero na cota topográfica especificada. Nestes pontos, o aqüífero não sofrerá alterações significativas em relação à sua configuração inicial, fazendo com que a direção do fluxo também não seja significativamente alterada.

\subsection{Análise de sensibilidade}

Os resultados gerados pela simulação devem ser visualizados como representativos do comportamento médio do aqüífero, em virtude das simplificações físicas e matemáticas que já foram admitidas na análise de sensibilidade da calibração do modelo.

É importante destacar que o modelo é utilizado para simular a condição de equilíbrio final do aqüífero em resposta ao enchimento do reservatório, não sendo computadas as influências sazonais.

\subsection{Instalação dos poços de monitoramento}

Uma vez concluída a simulação do enchimento do reservatório, procedeu-se à escolha da localização dos poços de monitoramento. Foram priorizadas as áreas que sofreriam maior impacto nos níveis de águas subterrâneas. Dos treze poços de monitoramento instalados, três, o BPZ-21, BPZ-27 e o BPZ-26, foram locados próximos à cota de desapropriação, visando a sua utilização como controle da extensão real da área de influência do reservatório. 
Devido ao fato do poço BPZ-16 não ter apresentado nível d'água até o topo rochoso inalterado, resolveu-se instalar um poço de monitoramento complementar, o BPZ-28, para auxiliar, junto ao BPZ-16, no monitoramento do local previamente designado.

Foi constatada a presença de três poços de controle geotécnico a jusante da barragem de Biritiba-Mirim, que foram aproveitados para complementar os dados do monitoramento.

Apresenta-se na TABELA 10.1 as principais informações geográficas e hidrogeológicas dos poços de monitoramento instalados no reservatório de BiritibaMirim.

A litologia da área segue predominantemente a seguinte seqüência, do topo para a base: horizonte superficial rico em matéria orgânica nos primeiros $0,30 \mathrm{~m}$, solo arenoso com lentes de argila, em alguns casos intercalados com camadas argilosas de espessura superior a $1,5 \mathrm{~m}$, retornando a arenoso até atingir o N.A. (ANEXO D). As profundidades do nível d'água variam de $2,1 \mathrm{~m}$ no $\mathrm{BPZ}-25$ a 12,9 m no BPZ - 22 .

TABELA 10.1 - Poços de monitoramento instalados na bacia de contribuição do reservatório de Biritiba-Mirim em maio/junho de 2000.

\begin{tabular}{|c|c|c|c|c|c|c|}
\hline \multirow{2}{*}{$\mathrm{N}^{\circ}$ do poço } & \multicolumn{3}{|c|}{ Coordenadas UTM (m) } & \multirow{2}{*}{$\begin{array}{l}\text { Profundidade } \\
\text { do poço }(\mathrm{m})\end{array}$} & \multirow{2}{*}{$\begin{array}{c}\text { Profundidade } \\
\text { do nível } \\
\text { d'água }(\mathrm{m}) \\
\end{array}$} & \multirow{2}{*}{$\begin{array}{c}\text { Cota } \\
\text { potenciométrica } \\
(\mathrm{m})\end{array}$} \\
\hline & $x$ & $\mathrm{y}$ & $z$ & & & \\
\hline $\mathrm{BPZ}-16$ & 389516 & 7389131 & 755,0 & 12,8 & * & * \\
\hline BPZ - 17 & 391001 & 7388811 & 762,0 & 11,0 & 3,5 & 758,5 \\
\hline BPZ - 18 & 389748 & 7387678 & 760,0 & 11,0 & 10,3 & 749,7 \\
\hline BPZ - 19 & 389025 & 7385838 & 760,0 & 11,0 & 7,8 & - \\
\hline $\mathrm{BPZ}-20$ & 388134 & 7382913 & 770,0 & 12,5 & 12,1 & 757,9 \\
\hline $\mathrm{BPZ}-21$ & 391759 & 7384032 & 770,0 & 9,3 & 5,6 & 764,4 \\
\hline $\mathrm{BPZ}-22$ & 388647 & 7388942 & 753,0 & 14,0 & 12,9 & 740,1 \\
\hline $\mathrm{BPZ}-23$ & 388271 & 7387718 & 768,0 & 10,5 & 7,1 & 760,9 \\
\hline BPZ - 24 & 388159 & 7385511 & 764,0 & 12,0 & 10,8 & 753,2 \\
\hline BPZ - 25 & 390029 & 7381484 & 763,5 & 11,0 & 2,1 & 761,5 \\
\hline BPZ - 26 & 391725 & 7381316 & 774,5 & 11,0 & 7,1 & 767,4 \\
\hline BPZ - 27 & 391639 & 7383108 & 765,0 & 11,0 & 6,8 & 758,2 \\
\hline BPZ - 28 & 389348 & 7389169 & 764,5 & 11,0 & 8,4 & 756,1 \\
\hline
\end{tabular}

* : não atingiu o nível d'água.

- : ausência de dado. 


\section{VERIFICAÇÃO DO MODELO}

A verificação do modelo, implica na utilização de um conjunto de parâmetros e estresses já calibrados, para reproduzir um segundo conjunto de dados de campo.

Com esse objetivo, foram calculadas novas taxas de recarga do aqüífero, representativas do período a ser simulado. A simulação foi então realizada em estado transitório para o período de interesse. Um dos parâmetros calibrados durante este processo foi o coeficiente de armazenamento, que é utilizado na definição do período de monitoramento posterior ao enchimento.

As cargas hidráulicas resultantes da nova simulação foram, então, comparadas com aquelas observadas em campo no período simulado, permitindo avaliar o funcionamento do modelo.

Descrevem-se, a seguir, as atividades desenvolvidas durante o processo de verificação.

\subsection{Coleta de dados}

Esta fase incluiu a coleta de dados e informações necessárias para executar a verificação do modelo e monitorar o aqüífero antes do enchimento do reservatório.

\subsubsection{Ensaios de permeabilidade}

Foram realizados ensaios de permeabilidade nos poços de monitoramento BPZ17, BPZ-23, BPZ-26 e BPZ-27. A execução destes testes teve a finalidade de estimar o coeficiente de permeabilidade do aqüífero, e checar os valores obtidos na calibração do modelo. Os resultados indicaram que a permeabilidade varia de 0,17 a 1,24 m/d (ANEXO E), valores situados dentro do intervalo indicado por HEATH (1983), para areias finas siltosas (permeabilidades de 0,05 a $10 \mathrm{~m} / \mathrm{d}$ ).

Comprovou-se que os valores utilizados na elaboração do modelo matemático são concordantes com os valores obtidos em campo. 


\subsubsection{Monitoramento anterior ao enchimento do reservatório}

Foi realizado o monitoramento do nível freático durante o período de um ano, ainda sem a presença do reservatório, nos meses de maio/junho/2000, setembro/2000, dezembro/2000 e março/2001 (ANEXO F, TABELAS F1 e F2).

No decorrer da instalação dos poços de monitoramento na bacia do rio BiritibaMirim, em maio/junho/2000, foram observadas profundidades de níveis d'água variáveis entre 2,1 m (BPZ-25) e 12,9 m (BPZ-22). De acordo com os resultados obtidos ao longo do monitoramento (ANEXO F, TABELA F1), a profundidade máxima de nível d'água ocorreu no BPZ-30, que apresentou variação de 14,3 para 14,4 m, com mínima em março e máxima em setembro. Os níveis mais rasos foram observados no BPZ-25, com variação de 1,4 para 1,7 m, com mínima em setembro e máxima em março.

No mês de setembro, $50 \%$ dos poços de monitoramento rebaixaram seus níveis d'água, em até 0,6 m (BPZ-18), e 42\% tiveram seus níveis elevados em até 0,9 m (BPZ-26).

Pode-se observar que no mês de dezembro ocorreu a elevação generalizada no nível d'água dos poços de monitoramento, em até 2,0 m (BPZ-26), com exceção do BPZ-22, que apresentou rebaixamento de 0,1 m.

Por outro lado, em março, os poços de monitoramento apresentaram tanto elevação do nível d'água (em $42 \%$ dos casos), quanto rebaixamento (em $58 \%$ dos casos). O valor máximo de elevação foi de 0,6 $\mathrm{m}$ no BPZ-18, enquanto que o rebaixamento máximo de 2,3 m ocorreu no BPZ-26.

Em relação ao nível d'água dos poços cadastrados (ANEXO F, TABELA F2), nos meses de maio/junho, observou-se um rebaixamento de até 2,0 m (BM-56) e uma elevação máxima de 2,6 m (BM-25). O nível mais raso, de 0,9 m, ocorreu no BM-52 e o mais profundo, de $21,5 \mathrm{~m}$, no BM-07. Em $77 \%$ dos poços monitorados, foi constatada a elevação do N.A. em relação aos níveis observados no mês de novembro/1999.

Em setembro, o maior rebaixamento observado no nível d'água subterrânea dos poços cadastrados foi de 1,3 m (BM-25), e a elevação máxima de 1,8 m (BM-49); o nível mais raso, de 0,5 m, ocorreu no BM-63 e o mais profundo, de 21,7 m, no BM-07. Em 65\% dos poços monitorados foi constatado o rebaixamento do N.A. em relação aos níveis obtidos nos meses de maio/junho/2000. 
No mês de dezembro, os poços cadastrados apresentaram rebaixamento no nível d'água de até 1,4 m (BM-02) e elevação máxima de 4,1 m (BM-03). O nível mais raso, de 0,3 m, ocorreu no BM-48 e o mais profundo, de 21,4 m, no BM-07. Em 88\% dos poços monitorados foi constatada a elevação do N.A. em relação aos níveis obtidos no mês de setembro/2000.

Em março, o rebaixamento no nível d'água dos poços cadastrados atingiu 2,0 $\mathrm{m}$ (BM-56) e a elevação máxima de 2,6 m, no BM-64. O nível mais raso, de $0,4 \mathrm{~m}$, foi observado no BM-63 e o mais profundo, de 21,0 m, no BM-04. Em 69\% dos poços monitorados foi constatado o rebaixamento no N.A. em relação à posição observada no mês de dezembro/2000.

\subsubsection{Cálculo de recarga para o período monitorado}

A precipitação e a irrigação, fatores de recarga do sistema aqüífero livre na área, regem o comportamento da superfície potenciométrica, cujo tempo de resposta aos eventos de aporte de água vai depender das características hidráulicas do sistema. Fatores como a permeabilidade, transmissividade, posição topográfica, dentre outros, exercem um papel fundamental nesse processo.

A precipitação pluviométrica medida na estação de Biritiba-Mirim, no período que se estende de abril de 2000 a março de 2001, totalizou $1.316 \mathrm{~mm}$. Esse valor se mostrou consideravelmente inferior à média anual obtida na Estação Climatológica Casa Grande (2.005 mm), localizada no município de Biritiba-Mirim (Prefixo: E2-110, altitude $880 \mathrm{~m}$, coordenadas UTM 7.386.036 m N e 403.099 m E), e superior à média de $1.248 \mathrm{~mm} / \mathrm{ano}$, obtida no posto pluviométrico de Salesópolis (Prefixo:E2-131, altitude 790 m, coordenadas UTM 7.393.492 m N e 414.957 m E) (DAEE, 2000).

O período chuvoso se estende de novembro a março e os meses mais secos concentram-se entre abril e junho (FIGURA 11.1), sendo que a precipitação mínima mensal observada foi de $6 \mathrm{~mm}$ em abril/2000, e a máxima, de $307 \mathrm{~mm}$ em dezembro/2000 (TABELA 11.1).

A precipitação mensal do período apresentou oscilações significativas em relação às médias mensais observadas nos postos de Salesópolis e na Estação Casa Grande, especialmente em outubro/2000 e janeiro/2001. 


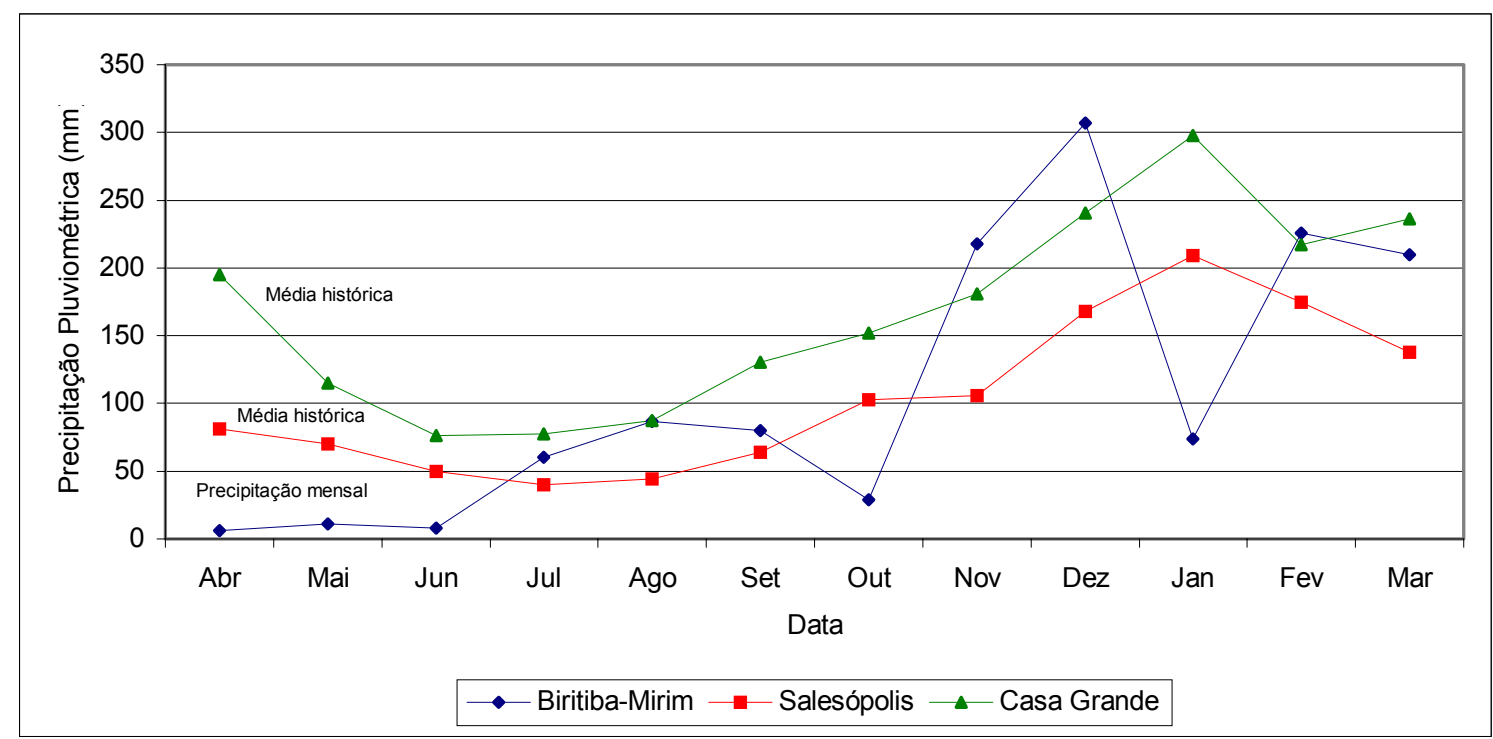

FIGURA 11.1 - Precipitação pluviométrica registrada na barragem de Biritiba-Mirim, entre abril/2000 e março/2001, e médias mensais históricas do posto de Salesópolis e da Estação Casa Grande

TABELA 11.1 - Precipitação pluviométrica durante o período de monitoramento do aqüífero freático.

\begin{tabular}{cc}
\hline Mês & $\begin{array}{c}\text { Precipitação pluviométrica } \\
(\mathrm{mm})^{*}\end{array}$ \\
\hline Abr/00 & 6 \\
Mai/00 & 11 \\
Jun/00 & 8 \\
Jul/00 & 60 \\
Ago/00 & 87 \\
Set/00 & 80 \\
Out/00 & 29 \\
Nov/00 & 218 \\
Dez/00 & 307 \\
Jan/01 & 74 \\
Fev/01 & 226 \\
Mar/01 & 210 \\
\hline
\end{tabular}

*Fonte: DAEE, boletim pluviométrico de campo (medidor instalado na barragem de BiritibaMirim). 


\subsection{Processo de verificação}

O modelo, inicialmente calibrado, foi submetido ao processo de verificação, no qual foram simuladas, em estado de fluxo transitório, cargas hidráulicas médias do mês de dezembro de 2000. Os dados de N.A. foram medidos em campo, nos poços que compõem a rede de monitoramento da bacia do rio Biritiba-Mirim. O processo de modelagem considerou a variação mensal de recarga e de evapotranspiração real nos período de abril à primeira quinzena de dezembro. Como carga hidráulica inicial, foram utilizados os valores resultantes da calibração.

A recarga mensal do período foi estimada de acordo com a equação 7.4 , sendo considerada deficiência hídrica nos meses de abril a junho, e outubro de 2000, calculado pelo balanço hídrico edafológico a partir da metodologia proposta por Thornthwaite e Mather (apud AGENA et al., 2000). Para o cálculo, foram considerados os valores de evapotranspiração potencial, previamente calculados por AGENA et al. (op. cit.), para a região de Mogi das Cruzes, em conjunto com os dados de precipitação pluviométrica do período modelado (TABELA 11.2).

Nos meses restantes foi considerada recarga de 35\% da precipitação mensal. Este valor corresponde à taxa média de recarga obtida durante a elaboração do modelo conceitual (item 7.3) (TABELA 11.2).

Para efetuar a simulação em estado fluxo transitório, foi necessário definir o coeficiente de armazenamento do aqüífero. De acordo com o DAEE (1975), esse parâmetro, estimado a partir do conhecimento da natureza litológica, oscila entre $2 \%$ e $10 \%$ nas camadas sedimentares. Em relação à região do Sistema Aqüífero Cristalino, o balanço meteorológico da Bacia do Tietê indicou que os valores poderiam variar entre 0,5 e 5\% (SABESP-CEPAS, 1994).

O procedimento de verificação envolveu a calibração do modelo em situação de fluxo transitório, e a conseqüente determinação do coeficiente de armazenamento do aqüífero. 
TABELA 11.2 - Valores de precipitação e evapotranspiração utilizados na verificação do modelo.

\begin{tabular}{|c|c|c|c|}
\hline Mês & $\begin{array}{l}\text { Precipitação }^{1}(P) \\
(\mathrm{m} / \mathrm{d})\end{array}$ & $\begin{array}{l}\text { Evapotranspiração } \\
\text { potencial }^{2}(E T P)(\mathrm{m} / \mathrm{d})\end{array}$ & $\begin{array}{l}\text { Recarga total calculada } \\
\qquad(\mathrm{m} / \mathrm{d})\end{array}$ \\
\hline $\mathrm{Abr} / 00$ & 0,0002 & 0,0019 & 0,0062 \\
\hline Mai/00 & 0,0004 & 0,0010 & 0,0067 \\
\hline Jun/00 & 0,0003 & 0,0006 & 0,0068 \\
\hline Jul/00 & 0,0019 & 0,0014 & 0,0007 \\
\hline Ago/00 & 0,0028 & 0,0017 & 0,0010 \\
\hline Set/00 & 0,0027 & 0,0022 & 0,0009 \\
\hline Out/00 & 0,0009 & 0,0023 & 0,0065 \\
\hline Nov/00 & 0,0073 & 0,0031 & 0,0025 \\
\hline Dez/00 & 0,0099 & 0,0034 & 0,0035 \\
\hline \multicolumn{4}{|c|}{$\begin{array}{l}\text { Fonte: DAEE, boletim pluviométrico de campo (medidor instalado na barragem de } \\
\text { Biritiba-Mirim). }\end{array}$} \\
\hline \multicolumn{4}{|c|}{$\begin{array}{l}2 \text { Valor médio representativo para a região de Mogi das Cruzes. Fonte: AGENA et al. } \\
\text { (2000). }\end{array}$} \\
\hline \multicolumn{4}{|c|}{$\begin{array}{l}3 \text { Utilização da equação } 7.2 \text { nos meses com precipitação inferior a } 0,0010 \mathrm{~m} / \mathrm{d} \text {, e } \\
\text { aplicação do fator de recarga } 0,35 \text { nos meses restantes. }\end{array}$} \\
\hline
\end{tabular}

As cargas hidráulicas obtidas na verificação foram comparadas com as observadas em campo no mês de dezembro de 2001. A análise estatística dessa relação indicou um erro médio $(M E)$ de $0,5 \mathrm{~m}$, um erro médio absoluto $(M A E)$ de 2,5 m, e desvio padrão de 3,4 m (RMS), quando utilizado um coeficiente de armazenamento entre $1 \%$ e $7,5 \%$.

$\mathrm{Na}$ verificação do modelo foi obtida uma percentagem de resíduo de 5,3\%. Este valor foi considerado aceitável considerando-se os erros decorrentes de uma verificação em fluxo transitório, iniciada com as cargas hidráulicas e parâmetros resultantes da calibração (e seu respectivo erro), na qual foram simulados 259 dias (incluindo os primeiros 15 dias do mês de dezembro), estimada a recarga real para cada mês e calibrado o coeficiente de armazenamento do sistema.

A variação do armazenamento, realizada durante a análise de sensibilidade da verificação, indicou que o modelo não apresenta grande sensibilidade às modificações desse parâmetro, elevando o resíduo final para 5,5 e 5,4\%, nos casos em que o armazenamento foi multiplicado pelos fatores 0,5 e 1,5 , respectivamente. 


\section{ELABORAÇÃO DO MAPA PREVISIONAL DE INFLUÊNCIA}

A partir da etapa de verificação do modelo, deu-se por concluído o ajuste do modelo matemático, elaborado para a bacia de drenagem do rio Biritiba-Mirim.

Os parâmetros calibrados e verificados foram, então, transferidas para o modelo de simulação final do enchimento, repetindo-se as etapas anteriormente descritas neste trabalho (Capítulo 10).

Utilizando o mapa topográfico da área junto com o mapa potenciométrico resultante da simulação, foi elaborado o Mapa Previsional de Influência, que indica, nas áreas afetadas pelo reservatório, zonas de isoprofundidades do aqüifero livre, previstas para após o enchimento, no sistema já estabilizado.

A elaboração do Mapa Previsional de Influência visa a identificação de áreas passíveis de sofrerem os efeitos do enchimento do reservatório, expondo as limitações e potencialidades dos terrenos e apontando diretrizes para o uso e ocupação do solo.

No Mapa Previsional de Influência do reservatório de Biritiba-Mirim foram delimitadas duas zonas de influência potencial e uma zona sem influência do reservatório ou com profundidade final do nível freático superior a $10 \mathrm{~m}$ (DESENHO 04):

> ZONA A, que corresponde à zona onde a profundidade final prevista para a água subterrânea, estará situada entre 0 e $5 \mathrm{~m}$;

> ZONA B, que corresponde à zona onde a profundidade final prevista para água subterrânea, estará situada em níveis maiores que $5,0 \mathrm{~m}$;

$>$ ZONA C - que corresponde à área no entorno do reservatório onde o nível d'água subterrânea não deverá sofrer a influência do enchimento do lago, independentemente se a profundidade do nível freático é naturalmente rasa ou profunda. Esta zona inclui, também, as áreas que apresentam profundidade final do nível freático superior a $10 \mathrm{~m}$, e que eventualmente sofram qualquer influência do reservatório. 
De acordo com a previsão de enchimento do reservatório, o lago ocupará área aproximada de $12 \mathrm{~km}^{2}$. O Mapa Previsional de Influência apresentou as seguintes características:

> ZONA A - compreendeu faixa contínua de largura variável entre 10 e 360 m a partir da borda do reservatório (cota aproximada 757,5 m), ao longo das encostas do vale do rio Biritiba-Mirim e acompanhando as reentrâncias do lago. Abrangeu também os vários cursos d'água tributários nas duas margens do referido rio, ocupando o fundo e encostas das drenagens e estendendo-se por até $2.700 \mathrm{~m}$ a partir das extremidades dos braços do reservatório. Apresenta expressão superficial relativamente restrita, perfazendo $11,2 \mathrm{~km}^{2}$ (equivalente a $17,7 \%$ da área estudada).

$>$ ZONA B - delimitada a partir do limite exterior da Zona A, constituiu uma faixa de largura variável entre 8 e $260 \mathrm{~m}$ ao longo das margens do reservatório em toda a sua extensão, ocupando as posições de encosta e topos de divisores de águas superficiais e sendo deslocada pelas reentrâncias da Zona $\mathrm{A}$, ao longo dos cursos d'água tributários do rio Biritiba-Mirim. Apresenta expressão superficial menos significativa que a Zona $\mathrm{A}$, correspondendo a $5,8 \mathrm{~km}^{2}$, ou $9,2 \%$ da área estudada, em decorrência da topografia local, que se apresenta muito acidentada, que favorece a atenuação do efeito do enchimento do reservatório.

$>$ ZONA C - ocupa as porções externas da área estudada, em faixa que se estende no sentido leste-oeste a partir da Zona B, compreendendo indistintamente fundos de vales, encostas e topos de divisores de água superficiais. Constituiu faixa quase contínua, de largura entre 11 e $6.600 \mathrm{~m}$, com algumas interrupções nas áreas a montante e nos vales de algumas drenagens. Apresentou expressão superficial significativa, correspondendo a $46,2 \mathrm{~km}^{2}$ (equivalente a $73,0 \%$ da área estudada).

As repercussões potenciais da variação da profundidade do nível de água do aqüífero, em cada uma dessas zonas, encontram-se descritos no QUADRO 12.1. 


\begin{tabular}{|c|c|c|c|c|c|}
\hline \multirow[t]{2}{*}{$\begin{array}{l}\text { Influência } \\
\text { Potencial }\end{array}$} & \multirow{2}{*}{$\begin{array}{l}\text { Intervalo de } \\
\text { profundidade } \\
\text { do N.A. } \\
\text { previsto (m) }\end{array}$} & \multicolumn{3}{|c|}{$\begin{array}{l}\text { Repercussões } \\
\text { potenciais no uso e } \\
\text { ocupação do solo }\end{array}$} & \multirow[t]{2}{*}{ Alterações no aqüífero livre } \\
\hline & & Positivas & \multicolumn{2}{|c|}{ Negativas } & \\
\hline $\begin{array}{l}\text { MÁXIMA } \\
\text { (ZONA A) }\end{array}$ & $0-5$ & $\begin{array}{c}\text { P1, P2, P3, } \\
\text { P4, P5, P6, } \\
\text { P7 }\end{array}$ & \multicolumn{2}{|c|}{$\begin{array}{c}\text { N1, N2, N3, N4, } \\
\text { N5, N6, N7, N8, } \\
\text { N9 }\end{array}$} & \multirow{3}{*}{$\begin{array}{l}\text { - Afloramento do nível freático particularmente em zonas } \\
\text { topograficamente deprimidas } \\
\text { - Aumento da espessura saturada do aqüífero } \\
\text { - Aporte de volumes de água de características físico- } \\
\text { químicas diferentes } \\
\text { - Diminuição dos gradientes hidráulicos subterrâneos } \\
\text { - Aumento da vulnerabilidade à contaminação } \\
\text { - Colapsos no solo }\end{array}$} \\
\hline $\begin{array}{l}\text { INTERMEDIÁRIA } \\
\text { (ZONA B) }\end{array}$ & $5-10$ & $\begin{array}{c}\mathrm{P} 1, \mathrm{P} 2, \mathrm{P} 3 \\
\mathrm{P} 4, \mathrm{P} 7\end{array}$ & \multicolumn{2}{|c|}{$\mathrm{N} 1, \mathrm{~N} 3, \mathrm{~N} 7, \mathrm{~N} 9$} & \\
\hline $\begin{array}{c}\text { MÍNIMA OU NULA } \\
\text { (ZONA C) }\end{array}$ & Intervalo variável & $\mathrm{P} 1, \mathrm{P} 2, \mathrm{P} 7$ & \multicolumn{2}{|c|}{ N1, N7, N9 } & \\
\hline \multicolumn{6}{|c|}{ Repercussões potenciais } \\
\hline \multicolumn{4}{|c|}{ Negativas (N) } & & Positivas (P) \\
\hline \multicolumn{4}{|c|}{$\begin{array}{l}\text { N1 - Perda de pontos de captação de água instalados } \\
\text { N2 - Perda de produtividade de solos agricultáveis } \\
\text { N3 - Restrição de usos da água subterrânea } \\
\text { N4 - Recalque de fundações e danos em edificações } \\
\text { N5 - Recalque diferencial em subleito de vias } \\
\text { N6 - Proliferação de freatófitas } \\
\text { N7 - Geração, reativação ou aceleração de processos } \\
\quad \text { erosivos lineares } \\
\text { N8 - Instabilização de taludes marginais ao reservatório } \\
\text { N9 - Sismisidade }\end{array}$} & $\begin{array}{l}\text { P1 } \\
\text { P2. } \\
\text { P3. } \\
\text { P4 } \\
\text { P5 } \\
\text { P6 } \\
\text { P }\end{array}$ & $\begin{array}{l}\text { Aumento das reservas de águas subterrâneas } \\
\text { Maior facilidade de acesso aos recursos hídricos } \\
\text { subterrâneos } \\
\text { Melhoria da umidade subsuperficial dos solos } \\
\text { Melhoria no desenvolvimento de árvores que demandam } \\
\text { muita água } \\
\text { Perenização de cursos de água anteriormente } \\
\text { intermitentes } \\
\text { Formação de lagos em zonas topograficamente } \\
\text { deprimidas } \\
\text { Melhoria do padrão de qualidade das águas }\end{array}$ \\
\hline
\end{tabular}

Fonte: modificado de ALBUQUERQUE FILHO (2002).

QUADRO 12.1. - Repercussões potenciais no meio físico decorrentes da elevação induzida no nível freático

\section{1 Áreas de destaque quanto ao uso e ocupação do solo nas margens do reservatório}

A identificação de áreas de destaque quanto ao uso e ocupação do solo tem por objetivo criar um instrumento que, associado ao Mapa Previsional de Influência e ao de delimitação das principais áreas impactadas, possa subsidiar a tomada de decisão no sentido de minimizar ou até mesmo evitar as repercussões do impacto hidrogeológico do reservatório.

Foram considerados na categoria de áreas de destaque quanto ao uso e ocupação do solo nas margens do reservatório aqueles locais que apresentavam um ou mais tipos de estruturas de porte (como indústrias, usinas, obras/edificações e reservatórios enterrados ou aéreos), aglomerações populacionais e rurais (como assentamentos e projetos agrícolas), ou outros locais de destinação especial (como no 
caso de necrópoles, lagoas de tratamento de esgoto e lixões) relevantes para os objetivos do estudo.

A área nos entornos do reservatório de Biritiba-Mirim insere-se em paisagem tipicamente rural. Remanescentes naturais dominam grande parte das planícies fluviais e se estendem, no geral, às vertentes dos morrotes e morros que circundam os vales (FOTO 12.1).

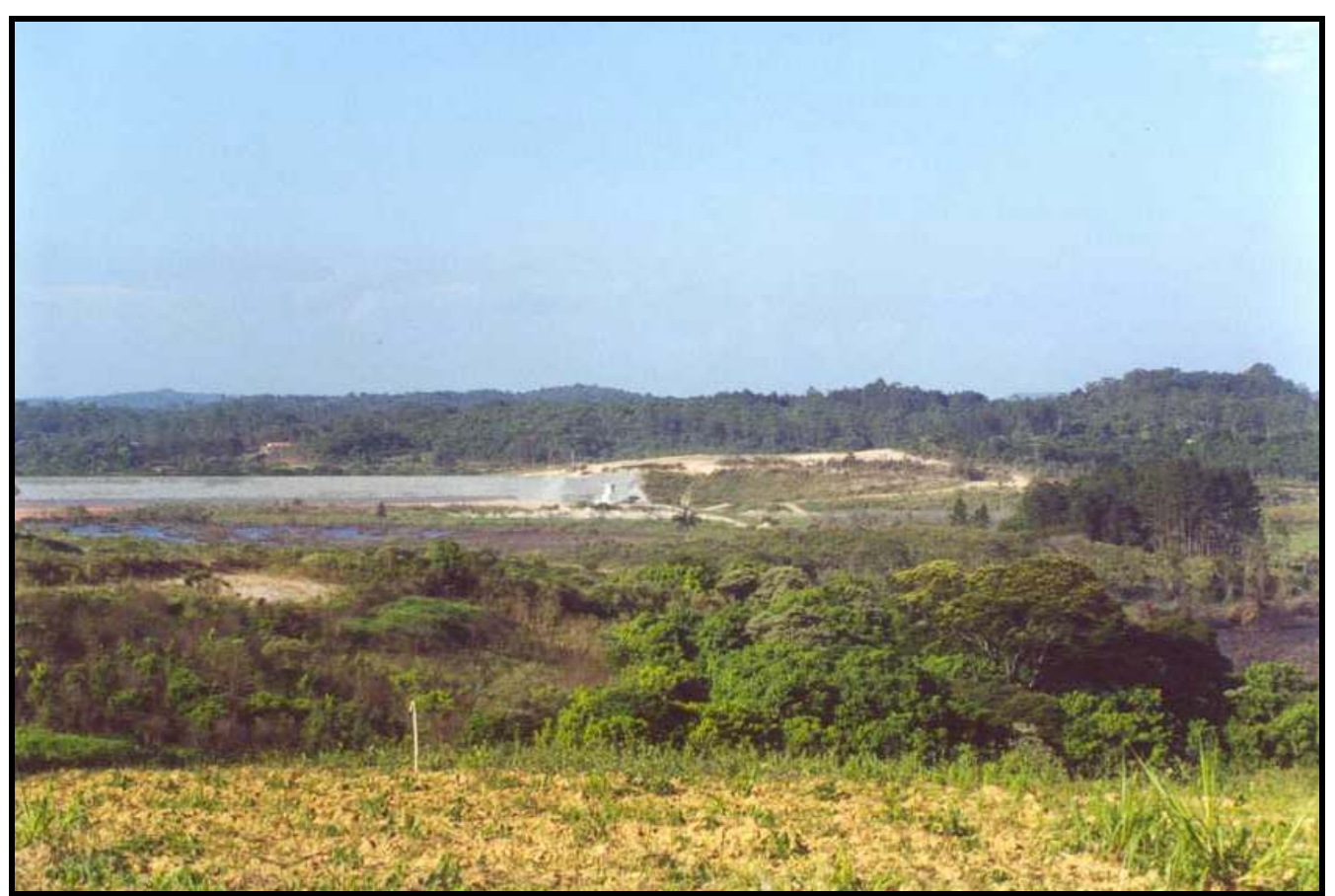

FOTO 12.1 - Presença de remanescentes naturais, capoeiras e pastagens, nas planícies fluviais do rio Biritiba-Mirim

De acordo com CCN (1997), 41,0\% da área total da bacia têm ocupação rural densa (FOTO 12.2), 21,2\% apresentam atividades de silvicultura, $25,4 \%$ são compostos por capoeiras e pastagens e 12,4\% por várzeas. 


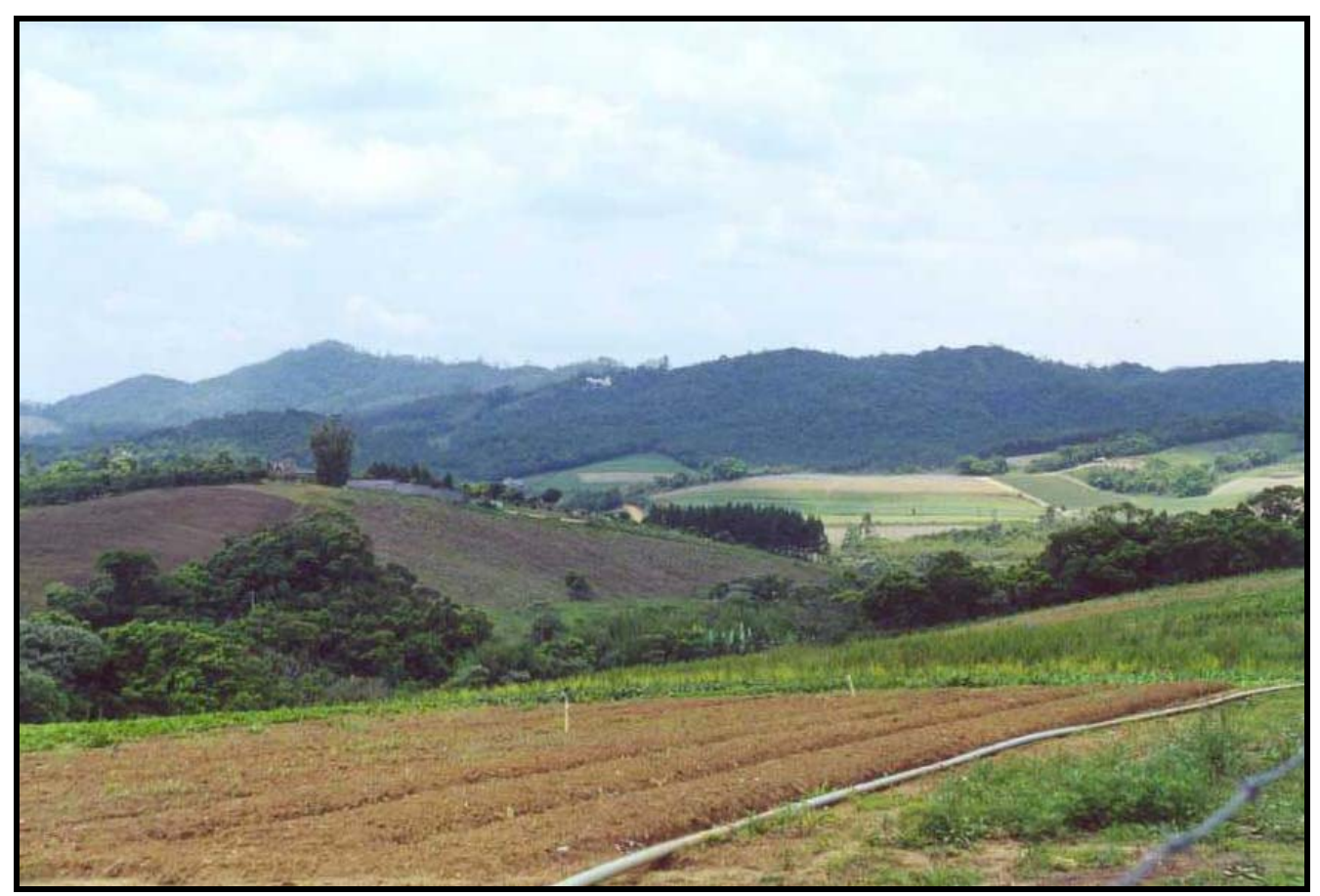

FOTO 12.2 - Atividades agrícolas desenvolvidas de forma intensiva nos morrotes e morros que circundam os vales da bacia do rio Biritiba-Mirim

Uma importante estrutura observada foi a torre de alta tensão localizada dentro do futuro lago, nas proximidades do poço BM-12. Atualmente, ela já se encontra sobre uma estrutura de pilastras que elevou sua base a níveis mais seguros (FOTO 12.3). 


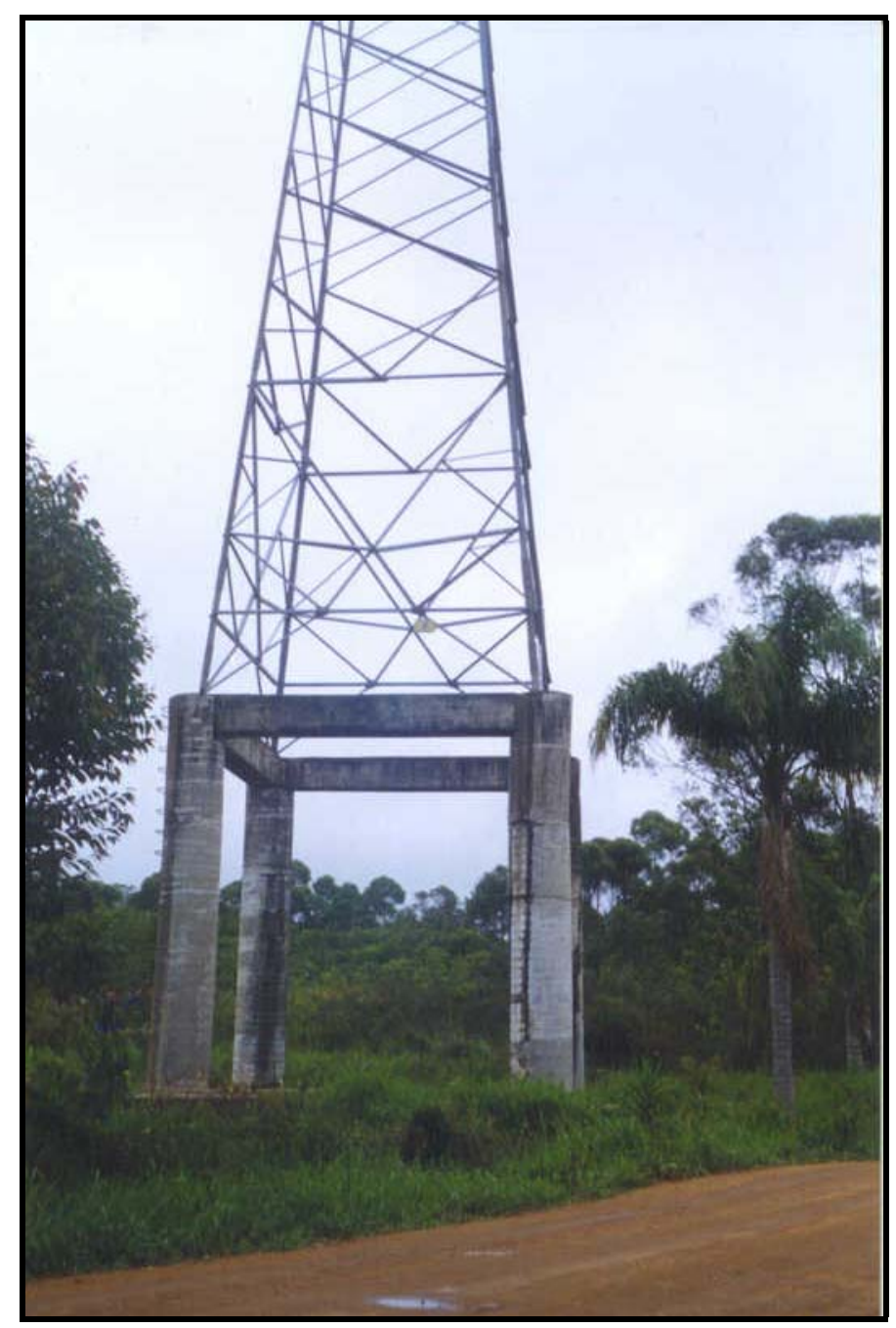

FOTO 12.3 - Torre de alta tensão localizada no vale do rio Biritiba-Mirim, em área a ser inundada

As observações de campo realizadas na área confirmaram a ausência de importantes áreas de destaque quanto ao uso e ocupação do solo nas margens do reservatório. As moradias rurais passíveis de serem afetadas pelo enchimento do reservatório já se encontram relocadas e as construções de maior expressão, utilizadas na criação de animais em sistema intensivo (principalmente avicultura e suinocultura), estão atualmente localizadas em terrenos mais elevados.

Apesar de não terem sido observadas importantes áreas de destaque quanto ao uso do solo, cabe ressaltar a questão da disposição de efluentes domésticos como fonte de contaminação, distribuída de forma esparsa, em função das moradias rurais. 
Outro ponto a ser considerado é o transporte de nutrientes e defensivos agrícolas, das áreas de uso agropecuário e de instalações de pecuária intensiva, para o meio natural por meio da lixiviação, o que pode levará à contaminação, de forma difusa, do aqüífero. Esse processo pode ser acelerado pela elevação dos níveis d'água subterrânea, principalmente na Zona $A$, tanto em função da diminuição do tempo de transporte do contaminante, como pelo contato direto do aqüífero com camadas de solo previamente contaminadas.

\subsubsection{Análise da disposição de dejetos domésticos nas bordas do reservatório}

Durante os trabalhos de cadastramento de pontos d'água, constatou-se a ocorrência de vinte e três fossas, dos sessenta e cinco pontos cadastrados na região do Biritiba-Mirim.

Observa-se uma lacuna nas informações obtidas a respeito da disposição de efluentes domésticos, em decorrência da ausência de conhecimento por parte do próprio informante.

Após o enchimento dos reservatórios, é provável que algumas fossas venham a ficar "afogadas" ou em condições inadequadas de acordo com os limites recomendáveis. De acordo com a literatura (LEWIS et al., 1986), o fundo da fossa deve situar-se de 1,5 a 3,0 m acima do nível d'água subterrânea no local, valores estes considerados como mínimos recomendáveis.

Segundo o conjunto amostral efetuado, as fossas aparecem distribuídas de forma esparsa numa região significativamente extensa, restringindo a uma escala local os riscos de contaminação do aqüífero por dejetos domésticos. 


\section{PROGRAMA DE MONITORAMENTO DO AQÜÍFERO FREÁTICO}

A elaboração do Mapa Previsional de Influência do reservatório de Biritiba-Mirim concluiu a primeira etapa da avaliação dos impactos hidrogeológicos do enchimento do reservatório sobre o nível freático regional. A execução do monitoramento do aqüífero posterior ao enchimento, permitirá realizar a retroanálise das previsões efetuadas na simulação.

Para definir um programa de monitoramento potenciométrico para a bacia foi simulada a resposta do aqüífero nos intervalos de 30 dias, 1 e 2 anos após o enchimento instantâneo do lago. A modelagem foi realizada tendo como base o modelo resultante da simulação do enchimento do reservatório, o coeficiente de armazenamento do modelo verificado e as cargas hidráulicas e médias de precipitação e evapotranspiração mensais do modelo calibrado.

Mediante a modelagem matemática foi possível caracterizar o impacto hidrogeológico espacial e temporalmente, considerando as características da bacia estudada.

De acordo com as simulações, o principal impacto deverá ocorrer no primeiro ano após o enchimento, sendo que os efeitos começarão a ser observados já no primeiro mês. Após o segundo ano, a variação do nível freático decorrente do enchimento deverá ser, em geral, inferior a 1,0 m.

A partir dos resultados obtidos com a simulação, foi elaborado o seguinte plano de monitoramento do aqüifero livre a ser executado após o fechamento da barragem de Biritiba-Mirim:

1) as medições da profundidade do nível d'água deverão ser efetuadas nos poços pertencentes à rede de monitoramento, durante um período de dois anos após o fechamento da barragem;

2) a primeira campanha de medição deverá coincidir com o início do enchimento do reservatório. A partir desta, as campanhas deverão ser mensais;

3) as medições mensais deverão ocorrer até os três primeiros meses após o enchimento, retomando-se, a partir daí, a periodicidade trimestral até o prazo previsto para o monitoramento. 
Concluída a fase de coleta de dados, as informações permitirão efetuar a avaliação dos resultados previstos e a continuidade, ou não, do monitoramento após o enchimento.Considerando que o enchimento do reservatório, inicialmente previsto para dezembro/2000, ainda não aconteceu, a continuidade do monitoramento é fundamental para a avaliação precisa do impacto hidrogeológico imediato, previsto para após o enchimento. Com esse objetivo, a periodicidade trimestral das campanhas de medição do nível d'água subterrânea servirão de base comparativa. 


\section{CONCLUSÕES E RECOMENDAÇÕES}

A execução do presente estudo comprovou a viabilidade da aplicação do Sistema de Informação Geográfica - SIG, associado à modelagem matemática com fins previsionais, em escala de bacia de contribuição, para a avaliação das modificações induzidas no nível do aqüifero livre após o enchimento de reservatórios.

A utilização do SIG e da modelagem matemática, como ferramentas no estudo desses impactos hidrogeológicos, possibilitou:

1) delimitar as áreas mais suscetíveis à influência hidrogeológica do reservatório;

2) elaborar o Mapa Previsional de Influência do reservatório, propiciando um instrumento de planejamento do uso e ocupação do solo;

3) definir o plano de monitoramento hidrogeológico adequado para o reservatório estudado.

Dentre as vantagens da utilização da modelagem matemática, está a possibilidade de considerar a heterogeneidade do meio físico, que afeta as direções de fluxo da água subterrânea. No entanto, a elaboração de um modelo matemático de boa qualidade depende do entendimento adequado do sistema hidrogeológico da área, que afeta diretamente a construção do modelo conceitual $e$, conseqüentemente, a confiabilidade da previsão.

A utilização do Sistema de Informação Geográfica foi fundamental na elaboração do modelo conceitual e durante todo o processo de modelagem, facilitando a calibração do sistema, a verificação do modelo e a simulação do enchimento do reservatório.

A partir da utilização do SIG, foi possível elaborar uma base de dados relativamente complexa, armazenando a diversidade de informações contidas no modelo conceitual. A facilidade do ajuste desses parâmetros e a rapidez de sua transferência para o modelo matemático permitiram otimizar a calibração do modelo. 
Essa é a etapa mais demorada do processo de modelagem, mas a de maior importância, pois nela pode-se observar a necessidade de levantamento de dados e/ou a revisão do modelo conceitual construído.

É importante lembrar que a aplicação de modelos matemáticos exige a utilização de grande quantidade de informações a respeito da área; portanto, a solução não será necessariamente única para um dado problema. É a partir do processo de verificação que se torna possível avaliar se o modelo calibrado reproduz o funcionamento real do sistema hidrogeológico. Essa etapa permite identificar e direcionar a necessidade de levantamento de novos dados, além de destacar as principais limitações do modelo proposto.

O uso do SIG associado à modelagem matemática mostrou-se, uma vez mais, uma importante ferramenta no processo de simulação da resposta do aqüifero livre ao enchimento do reservatório. A inserção de um novo elemento (o lago), numa base de dados previamente calibrada, ocorreu de forma simplificada na estrutura do SIG e a posterior transferência das informações para o modelo matemático possibilitou, pela sua precisão, a avaliação do impacto hidrogeológico real, dentro das limitações do modelo.

Um dos produtos mais importantes desta pesquisa é o Mapa Previsional de Influência do reservatório sobre o aqüífero livre. A elaboração do Mapa visa subsidiar o planejamento e a tomada de decisão nas áreas atingidas, facilitando a identificação dos interesses que serão afetados e contribuindo para a avaliação de riscos no que se refere à delimitação das áreas com probabilidade de ocorrência do evento.

A utilização da modelagem matemática no planejamento do monitoramento do aqüifero posterior ao enchimento do lago permitirá acompanhar a variação das cargas hidráulicas ao longo do tempo. A simulação do impacto do reservatório, em determinados períodos após seu enchimento, possibilita o planejamento de um monitoramento específico, aplicável à bacia estudada, considerando os efeitos que irão depender das características de cada sistema.

A partir da simulação do efeito do enchimento do reservatório de Biritiba-Mirim no aqüífero livre adjacente, foi observado que:

1) as áreas de maior condutividade hidráulica do aqüifero apresentam um tempo de resposta menor ao enchimento; 
2) a proximidade de áreas de descarga (rios e drenagens não afetados pelo reservatório), tende a minimizar o impacto;

3) as áreas próximas ao reservatório apresentaram resposta já no primeiro mês após o enchimento;

4) a proximidade do divisor d'água tende a aumentar o tempo de resposta do aqüífero;

5) a morfologia da região é, também, fator determinante do tempo de resposta do sistema;

6) as áreas que sofreram maior amplitude de elevação do nível de descarga apresentaram um tempo de resposta menor ao impacto.

De acordo com a modelagem, o impacto do enchimento do reservatório de Biritiba-Mirim deverá ser observado já no primeiro mês após o seu enchimento, e os principais efeitos deverão ser sentidos durante o primeiro ano.

A modelagem matemática em escala de bacia de contribuição constitui-se numa ferramenta importante para a determinação das principais áreas impactadas, as quais poderão ser indicadas para a realização de estudos de detalhe. A elaboração de uma base de dados georeferenciados, contendo as informações do modelo calibrado, possibilita a transferência direta dessas informações para um modelo matemático mais detalhado.

A aplicação do método proposto deve ser orientada de acordo com as etapas descritas neste trabalho, que está inserido num contexto mais amplo, o da previsão da elevação do nível freático no processo de avaliação de impacto ambiental de reservatórios. O método permitiu concluir a caracterização geral do reservatório, disponibilizando as informações do modelo calibrado para o detalhamento $\mathrm{e}$ viabilizando a elaboração de uma proposta de monitoramento específica para o reservatório estudado.

Destaca-se a importância da realização da postaudit, que implica na coleta de novos dados de campo para aferir se as previsões foram corretas. Essa etapa de monitoramento e retroanálise deve ser executada em tempo compatível com a previsão efetuada, para permitir que eventuais mudanças significativas possam ocorrer. 0 modelo matemático proposto, caso a previsão tenha-se confirmado, pode ser validado, especificamente para essa área. 
Deverá ser considerado, também, que os resultados obtidos a partir da metodologia proposta neste estudo apresentarão erros e limitações inerentes a um processo de modelagem desenvolvido em escala de bacia de contribuição (no caso, 1:25.000). Portanto, a utilização das informações resultantes deverá ser restrita à finalidade proposta neste trabalho, considerando-se a avaliação do erro de cada uma das etapas aqui desenvolvidas. 


\section{BIBLIOGRAFIA}

AGENA, S. S.; SAAD, A. M.; STEFANI, F. L.; AZEVEDO, S. G.; HELLMEISTER Jr. Z.; SILVA, L. A. P.; CANIL, K.; ALMEIDA, M. C. J.; CAVANI, A. C. Subsídios do meio físico para o planejamento do desenvolvimento da irrigação na Bacia Hidrográfica do Alto Tietê (BH-AT). São Paulo: Instituto de Pesquisas Tecnológicas do Estado de São Paulo S.A. - IPT, 2000. 140 p. (Relatório No 44.667).

ALBUQUERQUE FILHO, J. L. Previsão e análise da elevação do lençol freático no processo de Avaliação de limpacto Ambiental (AIA) de reservatórios hidrelétricos. 2002. 223 f. Tese de Doutorado - Instituto de Geociências e Ciências Exatas, Universidade Estadual Paulista, Rio Claro.

ALBUQUERQUE FILHO, J. L. Oscilações induzidas no freático e as repercussões ao uso do solo. Curso de Geologia aplicada ao meio ambiente. São Paulo: IPT/ABGE, Publicação ABGE. 1995. p. 135-148. Série Meio Ambiente.

ALBUQUERQUE FILHO, J. L. Determinação da superfície do lençol freático natural e induzida pelo enchimento do reservatório de Porto Primavera na área de Vila Nova Porto XV de Novembro, Bataguassu, MS. São Paulo: Instituto de Pesquisas Tecnológicas do Estado de São Paulo S.A. - IPT, 1993. 24 p. (Relatório № 31.799).

ALBUQUERQUE FILHO, J. L.; BOTTURA, J. A.; JUNIOR, T. B.; CORRÊA, W. A. G. Avaliação de impactos hidrogeológicos como subsídio à instalação de reservatórios hidrelétricos no estado de São Paulo. In: CONGRESSO BRASILEIRO DE ÁGUAS SUBTERRÂNEAS, 8., 1994, Recife. Anais...Recife, 1994. p. 169 - 179.

ALBUQUERQUE FILHO, J. L. \& LEITE, C. B. B. Detalhamento do potencial de influência da implantação do lago da barragem de Taquaruçu sobre o sistema aqǘfero livre no subtrecho $\mathbf{C} 1$ do reservatório: segunda fase. São Paulo: Instituto de Pesquisas Tecnológicas do Estado de São Paulo S.A. - IPT, 1992. 55 p. (Relatório $\mathrm{N}^{\circ}$ 29.971).

ALBUQUERQUE FILHO, J. L.; LEITE, C. B. B.; AZEVEDO, S. G.; NAKANDAKARE, K. C.; FERRER, L. M. Determinação do potencial de influência do enchimento dos reservatórios de Canoas I e II sobre o lençol freático regional: primeira fase. São 
Paulo: Instituto de Pesquisas Tecnológicas do Estado de São Paulo S.A. - IPT, 1996. 39 p. (Relatório No 33.909).

ALBUQUERQUE FILHO, J. L.; SILVA, A. L. B.; JÚNIOR, T. B.; CORREA, W. A. G. Alteração do nível freático induzida pelo enchimento do reservatório de Três Irmãos, em Pereira Barreto, SP. In: SIMPÓSIO DE GEOLOGIA DO SUDESTE, 5., 1997, Penedo/ltatiaia. Atas... Rio de Janeiro: SBG/ABGE, 1997. p. 190-192.

ALMEIDA, F. F. M. Mapa geológico do Estado de São Paulo. Texto. São Paulo: IPT, 2 v. 1981. Escala 1:500.000. Publicação n.1184, Série Monografias, 6.

ANDERSON, M. P. \& CHENG, X. Long and short-term transience in a groundwater/lake system in Wisconsin, USA. Journal of Hydrology, Amsterdam, n. 145, p. 1-18, 1993.

ANDERSON, M. P. \& MUNTER, J. A. Seasonal reversals of groundwater flow around lakes and the relevance to stagnation points and lake budgets. Water Resources Research, Washington, v. 17. n. 4, p. 1139-1150, aug. 1981.

ANDERSON, M. P. \& WOESSNER, W. W. Applied groundwater modeling: simulation of flow and advective transport. Academic Press. San Diego. 1992. 381p.

ANDREWS, C. B. \& ANDERSON, M. P. Impact of a power plant on the ground-water system of a wetland. Water Resources Research, Washington, v. 16, n. 2, p. 105-111, mar/apr. 1978.

ASSOCIAÇÃO BRASILEIRA DE GEOLOGIA DE ENGENHARIA - ABGE. Manual de sondagens. São Paulo, 1999. p. 19-22. 4. ed. Boletim 3.

AZEVEdo, A. A.; MAgalHÃES, F. S.; DEHIRA, L. K.; NAKANDAKARE, K. C.; NAGATA, N.; DOZZI, L. de F.S. Avaliação dos efeitos do enchimento do reservatório da Barragem do Tijuco Alto (SP-PR) na percolação nos maciços carstificados da sua área de inundação. In: CONGRESSO BRASILEIRO DE GEOLOGIA DE ENGENHARIA, 9., 1999, Rio Claro. Boletim de Resumos... São Paulo: UNESP/USP,1999. p.64. 
AGENCIA NACIONAL DE ENERGIA ELÉTRICA - ANEL. Informações do setor elétrico. Disponível em: <http://www.aneel.gov.br>. Acesso em: 20 de junho de 2002.

AUTODESK. AutoCAD2000. Autodesk, Inc. 1999. 1 CD-ROM.

BÄCKMAN, Y. \& LUNDBERG, A. Environmental impacts due to groundwater level rising at Porto Primavera dam, São Paulo, Brazil. Göteborg, 1995. 57f. Master Thesis - Geologiska Institutionen, Chalmers Tekniska Högskola.

BISTRICHI, C. A.; CARNEIRO, C. D. R.; DANTAS, A. S. L.; PONÇANO, W. L.; CAMPANHA, G. A. C.; NAGATA, N.; ALMEIDA, M. A.; MELO, M. S.; CREMONINI, O. A. Mapa geológico do Estado de São Paulo. Escala 1:500.000. In: Mapa geológico do Estado de São Paulo. São Paulo: IPT, 1981. 2 v. Escala 1:500.000. Monografias, 6, Publicação, n. 1.184.

BOTTURA, J. A. Análise das alterações induzidas pelo enchimento do reservatório de Porto Primavera sobre o nível da água subterrânea na área do Posto Fiscal XV de Novembro, Bataguassu, MS. São Paulo: Instituto de Pesquisas Tecnológicas do Estado de São Paulo S.A. - IPT, 1994. 32 p. (Relatório No 32.670).

BOTTURA, J. A. Modelagem numérica tridimensional do fluxo subterrâneo na cidade de Pereira Barreto, SP. São Paulo: Instituto de Pesquisas Tecnológicas do Estado de São Paulo S.A. - IPT, 1993. (Relatório No 31.805).

BOtTURA, J. A. Avaliação do efeito do enchimento do reservatório de Porto Primavera sobre o nível piezométrico na área da Lagoa São Paulo: $2^{\mathrm{a}}$ fase. São Paulo: Instituto de Pesquisas Tecnológicas do Estado de São Paulo S.A. - IPT, 1985. 3 v. (Relatório N²2.039).

BOTTURA, J. A. \& SANTOS, J. P. Impacto Hidrogeológico de Reservatórios. In: CONGRESSO BRASILEIRO DE GEOLOGIA DE ENGENHARIA, 4., 1984, Belo Horizonte. Anais... Belo Horizonte: ABGE, 1984. v. 2, p. 339-348.

BRASIL. Congresso. Senado. Resolução CONAMA. Direito admnistrativo. Tema: água. In: CABRAL, B. 1.ed. Brasília: Senado Federal, 1997. 670 p. Caderno Legislativo $\mathrm{n}^{\circ} 001 / 97$. 
BREDEHOEFT, J. D.; NEUZIL, C. E.; MILLY, P. C. D. Regional flow in the Dakota Aquifer: a study of the role of confining layers. USGS. Geological Survey Water Supply Paper, Washington, n. 2237. 45 p. 1983.

CADY, R. C. Effect upon ground-water levels of proposed surface-water storage in flathead lake, Montana. Geological Survey Water Supply Paper, Washington, n. 849B. p. 59-81, 1964.

CAVAlCANTE, J. C. \& KAEFER, L. Q. Projeto sudeste do Estado de São Paulo: Relatório Geológico Final. DNPM/CPRM, 1974. 234 p. Escala 1:250.000. Folha de Santos-Parcial. SF-23-Y-D, v-II.

CAVALCANTE, N. I. Estudo hidrogeológico de terreno cristalino com manto de intemperismo - Área piloto de Atibaia (SP). 1990. 123 f. Dissertação de Mestrado Instituto de Geociências, Universidade de São Paulo, São Paulo.

CAVAlCANTI, M. A. M. P.; AZEVEDO, S. G.; GIMENEZ FILHO, A.; LeITE, C. B. B.; SOUZA, L. A. P. Monitoramento do lençol freático nas áreas de influência dos reservatórios de Paraitinga e Biritiba, SP: Relatório Final. São Paulo: Instituto de Pesquisas Tecnológicas do Estado de São Paulo S.A. - IPT, 2001. 81 p. (Relatório No 48.800).

CCN - PLANEJAMENTO E ENGENHARIA S/C Ltda. Estudo de impacto ambiental. Sistema produtor Alto Tietê. Barragens de Biritiba-Mirim, Paraitinga e Complementação Taiaçupeba. São Paulo, 1997. 3 v. Relatório DAEE.

CESTARI JR., E. \& CELERI, A. Reflexos do enchimento do reservatório da UHE Três Irmãos nas edificações da cidade de Pereira Barreto. In: SEMINÁRIO NACIONAL DE GRANDES BARRAGENS, 23., 1999, Belo Horizonte. Anais...Belo Horizonte: CBDB, 1999. v. 2, p. 79-86.

CHENG, X. \& ANDERSON, M. P. Numerical simulation of ground-water interaction with lakes allowing for fluctuating lake levels. Ground Water, Dublin, v. 31, n. 6, p. 929-933, nov/dez. 1993.

CHERKAUER, D. S. \& HENSEL, B. R. Groundwater flow into lake Michigan from Wisconsin. Journal of Hydrology, Amsterdam, n. 84, p. 261-271, 1986. 
CHERKAUER, D. S. \& ZAGER, J. P. Groundwater interaction with a Kettle-Hole lake: relation of observations to digital simulations. Journal of Hydrology, Amsterdam, n. 109, p. 167-184, 1989.

CLEARY, R. W. Qualidade das águas subterrâneas. In: PORTO et al. Hidrologia ambiental. São Paulo: ABRH e EDUSP, 1991. p. 211-293.

CLEARY, R. W. Hidrologia de águas subterrâneas. In: RAMOS et al. 1989. Engenharia hidrológica. Rio de Janeiro: ABRH, 1989. p. 293-404.

COMISSÃO MUNDIAL DE BARRAGENS - CMB. Barragens e Desenvolvimento: Um Novo Modelo para Tomada de Decisões. 2000. Relatório. Disponível em : <http://www.damsreport.org>. Acesso em: maio de 2001.

COMITÊ BRASILEIRO DE GRANDES BARRAGENS - CBGB. Barragens, reservatórios e o meio ambiente. A prática brasileira. 1979. 92 p. Relatório da comissão técnica de barragens e o meio ambiente.

COMPANHIA DE PESQUISAS DE RECURSOS MINERAIS - CPRM. Carta geológica da folha de Mogi das Cruzes. São Paulo: CPRM, 1990. Escala 1:50.000. Índice de nomenclatura SF-23-Y-D-IV-2.

CONSÓRCIO HIDROPLAN. Águas subterrâneas e outros usos. Plano integrado de aproveitamento e controle de recursos hídricos das Bacias do Alto Tietê, Piracicaba e Baixada Santista. São Paulo: Hidroplan, v. 7, 1995.

CRUZ, W. B. da \& VERSIANI, B. R. Alterações de níveis do lençol freático no estudo de impactos ambientais de barragens. Revista Escola de Minas - Revista da Faculdade de Engenharia de Minas, Metalúrgica Geológica e Civil da Universidade Federal de Ouro Preto (UFOP). Ouro Preto: UFOP, ano 54, n. 3, v. 43, p. 18-22, 1990.

CUSTÓDIO, E. \& LLAMAS, M. R. Teoría elemental del flujo del agua en los medios porosos. Sección 8. In: Hidrologia Subterránea. 2.ed. Barcelona: Ediciones Omega S.A., 1996. p. 443-500.

DANCHIV, A.; MARTAC, E.; BTANCIUCU, M.; ZAMFIRESCU, F. Numerical simulation of the irrigation effects on the groundwater basin of a lake. In: CONGRESS OF 
INTERNATIONAL ASSOCIATION OF HYDROGEOLOGISTS, 29., 1999, Bratislava. Anais...Bratislava: IAH, 1999. 1 CD-ROM. p. 849-853.

DEPARTAMENTO DE ÁGUAS E ENERGIA ELÉTRICA - DAEE. Sistema de Informações para Gerenciamento de Recursos Hídricos do Estado de São Paulo SIGRH. Publicação eletrônica. Disponível em: <http://www.sigrh.sp.gov.br> Acesso em: 2000.

DEPARTAMENTO DE ÁGUAS E ENERGIA ELÉTRICA - DAEE. Estudo de águas subterrâneas. Região administrativa I. Grande São Paulo. São Paulo, vol. 1. 1975.

DEPARTAMENTO DE ÁGUAS E ENERGIA ELÉTRICA - DAEE/Consórcio BUREAU PROJECTUS. Sistema Produtor do Alto Tietê - SPAT. Projeto Básico Ambiental. 1998a. (Relatório N 4115.450).

DEPARTAMENTO DE ÁGUAS E ENERGIA ELÉTRICA - DAEE/Consórcio BUREAU PROJECTUS. Sistema Produtor do Alto Tietê - SPAT. Projeto Básico Ambiental: 08 - Programa de Monitoramento do Lençol Freático. Set. 1998b. (Relatório N ${ }^{\circ} 4115.458$ 50.M1.08).

DOMÉNICO A. P. \& SCHWARTZ, F. W. Physical and Chemical Hydrogeology. 2.ed. Ed. John Wiley \& Sons, Inc., 1997.

EMPRESA METROPOLITANA DE PLANEJAMENTO DA GRANDE SÃO PAULO S/A EMPLASA. Levantamento aerofotogramétrico. Município de Biritiba Mirim-SP. Folha Cruz do Alto. São Paulo: EMPLASA, 1996. Escala 1:10.000. Índice de nomenclatura SF-23-Y-D-IV-2-NE-F, articulação 5326.

EMPRESA METROPOLITANA DE PLANEJAMENTO DA GRANDE SÃO PAULO S/A EMPLASA. Levantamento aerofotogramétrico. Município de Biritiba-Mirim-SP. Folha Sogo. São Paulo: EMPLASA, 1988. Escala 1:10.000. Índice de nomenclatura SF-23-Y-D-IV-2-NE-E, articulação 5325.

EMPRESA METROPOLITANA DE PLANEJAMENTO DA GRANDE SÃO PAULO S/A EMPLASA. Levantamento aerofotogramétrico. Municípios de Salesópolis-SP, Biritiba-Mirim-SP e Moji das Cruzes-SP. Folhas Pico do Garrafão (SF-23-Y-D-IV-2SE-B), Fazenda Vanguarda (SF-23-Y-D-IV-2-SE-D), Biritiba Açu (SF-23-Y-D-IV-2- 
SE-A) e Parque Bela Vista (SF-23-Y-D-IV-2-SO-B). São Paulo: EMPLASA, 1982. Escala 1:10.000. Articulação 6321, 6312, 5342, 5343, 5341, 5344 e 5332.

EMPRESA METROPOLITANA DE PLANEJAMENTO DA GRANDE SÃO PAULO S/A EMPLASA. Mapa geológico da Grande São Paulo. São Paulo, 1980. Escala $1: 100.000$.

ENGINEERING COMPUTER GRAPHICS LABORATORY (ECGL) - Groundwater Modeling System, version 2.0. Boss International, Inc. and Brigham Young University, 1996. Conjunto de programas.1 CD-ROM.

FENSKE, J. P.; LEAKE, S. A.; PRUDIC, D. E. Simulating reservoir leakage in groundwater models. Ground Water, Dublin, v. 35, n. 5, p. 895-897, sep/oct. 1997.

FETTER, C. S. Applied hydrogeology. New Jersey. 3th ed. Prentice-Hall Ed, 1994. $516 \mathrm{p}$.

FRANKE, O. L.; REILLY, T. E.; BENNETT, G. D. Definition of boundary and initial conditions in the analysis of saturated ground-water flow systems: an introduction. USGS, Techniques of Water-Resources Investigations. n. TWI 03-B5. (Supersedes Open-file report 84-458). 15 p. 1987.

FREEZE, R. A \& CHERRY, J. A. Groundwater. New Jersey: Prentice - Hall, 1979. 604 p.

FREEZE, R. A. \& WITHERSPOON, P. A. Theoretical analysis of regional groundwater flow: 2 . Effect of water-table configuration and subsurface permeability variation. Water Resources Research, Washington, n. 3, p. 623-634, 1967.

FUNDAÇÃO ESTADUAL DE ENGENHARIA DO MEIO AMBIENTE - FEEMA. Vocabulário básico de meio ambiente. 2.ed. Rio de Janeiro: Imprensa Gráfica e Editora, 1990. $211 \mathrm{p}$.

FUNDAÇÃO INSTITUTO BRASILEIRO DE GEOGRAFIA E ESTATÍSTICA - IBGE. Censo demográfico. Rio de Janeiro, 2000. Disponível em: <http://www.ibge.gov.br/censo/ >. Acesso em: 10 de junho de 2002. 
FUNDAÇÃO INSTITUTO BRASILEIRO DE GEOGRAFIA E ESTATÍSTICA - IBGE. Censo demográfico. Rio de Janeiro, 1991.

FUNDAÇÃO NACIONAL DE SAÚDE - FUNASA/ MINISTÉRIO DA SAÚDE - MS. Diário Oficial, Brasília, n. 1-E, 2 jan. 2001, Seção 1, pág.19 e no Diário Oficial № 7-E de 10/1/2001. 2001.

GLOVER, R. E. Transient Ground Water Hydraulics. Michigan: Water Resources Publications, 1985, 413p.

GOVINDARAJU, R. S. \& KOELLIKER, J. K. Aplicability of linearized Boussinesq equation for modeling bank storage under uncertain aquifer parameters. Journal of Hidrology, Amsterdam, n. 157, p. 349-366, 1994.

GUO, W. Transient groundwater flow between reservoirs and water-table aquifers. Journal of Hydrology, Amsterdam, n. 195, p. 370-384, 1997.

HASUI, Y. Evolução polifásica do Pré-Cambriano a oeste da capital paulista. Boletim IG, São Paulo, n. 6, p. 95-107. 1975.

HASUI, Y. Tectônica da área das folhas de São Roque e Pilar do Sul. 1973. $190 \mathrm{f}$. Tese de Livre Docência - Instituto de Geociências, Universidade de São Paulo, São Paulo.

HASUI, Y.; DANTAS, A. S. L.; CARNEIRO, C. D. R.; BISTRICHI, C. A. O embasamento pré-Cambriano e Eo-paleozóico de São Paulo. In: Mapa Geológico do Estado de São Paulo. São Paulo: v. 2. 1981. Escala 1:500.000.

HEATH, R. C. Basic ground-water hydrology. USGS. Water Supply Paper, Washington, n. 2220, 84 p, 1983.

HIRATA, R. C. A. Fundamentos e estratégias de proteção e controle da qualidade das águas subterrâneas: estudo de casos no Estado de São Paulo. São Paulo, 1994. 195 f. Tese de Doutorado - Instituto de Geociências, Universidade de São Paulo, São Paulo.

HIRATA, R. C. A. \& FERREIRA, L. M. R. Os aqüiferos da bacia hidrográfica do Alto Tietê: disponibilidade hídrica e vulnerabilidade à poluição. Revista Brasileira de 
Geociências - Revista da Sociedade Brasileira de Geologia, São Paulo, v. 31, n. 1, p. 43-50, 2001.

HIRATA, R. C. A. \& SILVA da, A. N. Mapa hidrogeológico da Bacia do Alto Tietê. In: MACEDO, A. (coord.). Banco de Dados Espaciais da Bacia do Alto Tietê. São Paulo: LIG-Igc-USP, 1999. Disponível em meio eletrônico, no site: $<$ http//geolig.igc.usp.br>

HUISMAN, L. Groundwater recovery. London, UK: The Macmillan Press Ltda., 335 p. 1972.

HUNT, B. An approximation for the bank storage effect. Water Resources Research, Washington, v. 26, n. 11, p. 2769-2775, 1990.

IRITANI, M. A. Modelação matemática tridimensional para a proteção das captações de água subterrânea. São Paulo, 1998. 200 f. Tese de Doutorado Instituto de Geociências, Universidade de São Paulo, São Paulo.

KACIMOV, A. R. Three-dimensional groundwater flow to a lake: an explicit analytical solution. Journal of Hydrology, Amsterdam, n. 240, p. 80-89, 2000.

KAZMANN, R. G. New problems in hydrogeology. Journal of Hydrology, Amsterdam, v. 2, p. 92-100, 1964.

KRABBENHOFT, D. P.; ANDERSON, M. P.; BOWSER, C. J. Estimating groundwater exchange with lakes. Calibration of a three-dimensional, solute transport model to stable isotope plume. Water Resources Research, Washington, v. 26, n. 10, p. 24552462, oct. 1990 .

LEITE, C. B. B.; NAKANDAKARE, K. C.; ALBUQUERQUE FILHO, J. L. Modelagem numérica tridimensional das alterações induzidas pelo enchimento do reservatório de Porto Primavera sobre o nível das águas subterrâneas na área de Lagoa São Paulo e Bairro Campinal, Presidente Epitácio, SP. São Paulo. Instituto de Pesquisas Tecnológicas do Estado de São Paulo S.A. - IPT, 1997. 74 p. (Relatório $\left.N^{\circ} 34.767\right)$.

LEWIS, J. W.; FOSTER, S. S. D.; BRASAR, B. S. O risco de poluição do lençol freático por sistemas de disposição local de esgoto. Suíça: Ircwd, 1986. 92 p. 
LOCKINGTON, D. A. Response of uncontined aquifer to sudden change in boundary head. Journal of Irrigation and Drainage Engineering, New York, v. 123, n. 1, p. 2427, jan/feb. 1997.

LOGAN, J. The interpretation of chemical analyses of water. United Agency for International development. Recife. Brasil, 1965. 88p.

LOZINSKA-STEPIEN, H. \& POZNIAK, R. Engineering geological evaluation of increase in groundwater resources close to reservoirs. Bulletin of the International Association of Engineering Geology, Paris, n. 20, p. 273-274, 1979.

MARSILY, G. de. Quantitative Hydrogeology. Orlando: Academic Press, Orlando, 1986. $440 \mathrm{p}$.

McDONALD, M. G. \& HARBAUGH, A. W. MODFLOW - A modular three-dimensional finite-difference ground-water flow model. USGS. Book 6, Chapter A1, 528 p. 1988. (Geological Survey Open File Report 83-875).

MEDOVAR, Y. A. \& AKHMETYEVA, N. P. The reservoir effect on hydrological conditions of share areas of the ivankovo reservoir. Environmental Geology, New York, v. 5, n. 4, p. 219-224, 1984.

MELLO, S. O. Hidrelétricas: o sofisma da energia limpa. Saneamento Ambiental. Ano X, n.59, jul/ago, p. 32-37. 1999.

MENEGASSE-VELÁSQUEZ, L. N. Efeitos da urbanização sobre o sistema hidrológico: aspectos de recarga no aqüífero freático e o escoamento superficial. 1996. 124 f. Tese de Doutorado - Instituto de Geociências, Universidade de São Paulo, São Paulo.

MISTRETTA, G. Monitoramento do impacto hidrogeológico do reservatório de Porto Primavera na área da Lagoa São Paulo. São Paulo. Instituto de Pesquisas Tecnológicas do Estado de São Paulo S.A. - IPT, 1988. 137 p. (Relatório N² 26.661).

MISTRETTA, G. \& BOTTURA, J. A. Avaliação do efeito do enchimento dos reservatórios de Rosana e Taquaruçu sobre o nível piezométrico regional do sistema aqüífero livre: primeira fase. São Paulo. Instituto de Pesquisas Tecnológicas do Estado de São Paulo S.A. - IPT, 1986. 105 p. (Relatório No 24.063). 
MORI, R. T. Oscilações dos níveis freáticos e as repercussões na ocupação urbana. In: SEMINÁRIO DOS PROBLEMAS GEOLÓGICOS E GEOTÉCNICOS NA REGIÃO METROPOLITANA DE SÃO PAULO. Seção 4 - Problemas geotécnicos da urbanização. 1992. Atas...São Paulo: ABAS, ABGE e SBG/SP, 1992. p. 227-240.

MOTIDOME, M. J. Geologia do Complexo Embu na região entre Santa Isabel e Biritiba-Mirim, SP. São Paulo, 1992. 172 f. Dissertação de Mestrado - Instituto de Geociências, Universidade de São Paulo, São Paulo.

NAKANDAKARE, K. C. Assistência técnica relativa à avaliação hidrogeológica de detalhe da elevação do lençol freático na região do Distrito Campinal, em Presidente Epitácio - SP (áreas rurais). Instituto de Pesquisas Tecnológicas do Estado de São Paulo S.A. - IPT, 1998. (Relatório № 36.297).

NANEY, J. W. \& YOST, C. Jr. Earth-dam seepage and related land and water problems. Journal of Soil and Water Conservation. Ankeny. p.87-91, 3/4. 1975.

NEUMAN, S. P. \& WITHERSPOON, P. A. Theory of flow in a confined two aquifer system. Water Resources Research, Washington v. 5, n. 4, p. 803-816, 1969.

OLIVEIRA A. M. S. \& CORRÊA FILHO, D. Ensaios de permeabilidade em solos. Orientações para sua execução em campo. São Paulo, 1996. Boletim n.4. Associação Brasileira de Geologia de Engenharia.

PANDIT, A. \& EL-KHAZEN, C. C. Groundwater seepage into the Indian River lagoon at Port St. Lucie. Engineering Sciences, Florida, v. 53, n. 3, p. 169-179, 1990.

PAULDYAL, G. N. \& DAS GUPTA, A. Operation of a groundwater reservoir in conjunction with surface water. Water Resources Development, Oxfordshire, v. 3, n. 1, p. 31-43, 1987.

PINDER, G. F. A digital model for aquifer evaluation. USGS, Techniques of WaterResources Investigations. Book 7, Automated data processing and computations, Chapter C1, n. TWI 07-C1, 1970.

PIRES NETO, A. G. Abordagens sintético-histórica e analítico-dinâmica: uma proposição metodológica para a geomorfologia. São Paulo, 1992. 332 f. Tese de Doutorado - Faculdade de Filosofia, Letras e Ciências Humanas, Universidade de São Paulo, São Paulo. 
PONÇANO W. L.; CARNEIRO, C. D. R.; BISTRICHI, C. A; ALMEIDA, F. F. M.; PRANDINI, F. L. Mapa geomorfológico do estado de São Paulo - Notícia explicativa. v.1, 94p. 1981a. Convênio Pró-Minério/Promocet.

PONÇANO, W. L.; CARNEIRO, C. D. R.; BISTRICHI, C. A.; NETO, A. G. P.; ALMEIDA, M. A.; PRANDINI, F. L.; ÁVILA, I. G.; FORNASARI FILHO, N.; IWASA, O. Y. Mapa geomorfológico do Estado de São Paulo. São Paulo: Instituto de Pesquisas Tecnológicas do Estado de São Paulo S.A. - IPT, 1981b. Escala 1:1.000.000. (Monografia 5, Publicação, 1.183).

PRICKETT, T. A. \& LONNQUIST, C. G. Selected digital computer techniques for groundwater resources evaluation. Ilinois State Water Survey, Bulletin 55, 62 p. 1971.

REBOUÇAS, A. C. Condições de uso e proteção das águas subterrâneas. In: SEMINÁRIO DOS PROBLEMAS GEOLÓGICOS E GEOTÉCNICOS NA REGIÃO METROPOLITANA DE SÃO PAULO. Sessão 2 - Uso dos recursos minerais e das águas subterrâneas. 1992. Atas...São Paulo: ABAS, ABGE e SBG/SP, 1992. p. 77-87.

REED, J. E. \& BEDINGER, M. S. Estimating the effects of stream impounment on ground-water levels. Geological Survey Research, Washington, Article 35, n. P.B.88 and B.89, 1962.

REED, J. E. \& BEDINGER, M. S. Projecting the effect of changed stream stages on the water table. Journal of Geophysical Research, Washington, v. 6. n. 8, p. 2423-2427, aug. 1961.

RISK, Z. S. \& DABIS, A. D. Impact of proposed Quattara reservoir on the Moghra aquifer of northwestern Egypt. Ground Water. Dublin. v. 29, n. 2, p. 232-238, mar/apr. 1991.

ROCHA, G. A.; GONÇALVES, V. G.; REBOUÇAS, A.; BARRETO, L. M. B. Hidrogeologia da bacia de São Paulo. In: WORKSHOP GEOLOGIA DA BACIA DE SÃO PAULO, 1989, São Paulo. Atas...São Paulo: Ibc/USP e SBG/SP, 1989. p. 44-49.

ROSS, J. L. S.; MOROZ, I. C. Mapa geomorfológico do estado de São Paulo. São Paulo: FFLCH-USP/IPT, v.1, 64p. 1997. Escala 1:500.000. 
SABESP-CEPAS/Igc-USP. Diagnóstico Hidrogeológico da Região Metropolitana de São Paulo. Diagnóstico final. São Paulo, 115 p. 1994. Convênio Sabesp/CepasIGc/USP.

SACKS, L. A.; HERMAN, J. S.; KONIKOW, L. F.; VELA, A. L. Seasonal dinamics of ground water-lake interactions of Doñana National Park, Spain. Journal of Hydrology, Amsterdam, n. 136, p. 123-154, 1992.

SANTOS, J. P. Caracterização do efeito de enchimento do reservatório de Itaipu sobre o nível piezométrico regional, entre o eixo da barragem e Porto Mendes: primeira Fase. São Paulo: Instituto de Pesquisas Tecnológicas do Estado de São Paulo S.A. - IPT, 1984a. 58 p. (Relatório No 20.337).

SANTOS, J. P. Caracterização do efeito do enchimento do reservatório da barragem de Nova Avanhandava sobre a superfície piezométrica regional. São Paulo: Instituto de Pesquisas Tecnológicas do Estado de São Paulo S.A. - IPT, 1984b. 62 p. (Relatório No 20.231).

SANTOS, J. P. Avaliação do efeito do enchimento do lago da barragem de Três Irmãos sobre o nível piezométrico regional: primeira fase. São Paulo: Instituto de Pesquisas Tecnológicas do Estado de São Paulo S.A. - IPT, 1983. 2 v. (Relatório No 18.760).

SARAGIOTTO, L. F. R. Levantamento geológico das áreas de interesse para a implantação das barragens dos rios Biritiba e Jundiaí. São Paulo: Instituto de Pesquisas Tecnológicas do Estado de São Paulo S.A. - IPT, 1972. (Relatório No 6.364).

SATO, T. Fill dam leakage by network assessment. Advanced in Water Resources, Southampton, v. 13, n. 2, p. 85-89, 1990.

SEABER, P. R. Hydrostratigraphic units. In: BACK, W.; ROSENSHEIN, J. S.; SEABER, P. R. Hydrogeology: The geology of North America. Geol. Soc. Amer. 1988. v. 0-2. p.9-14. 
SENTELHAS, P. C.; PEREIRA, A. R.; MARIN, F. R.; ANGELOCCI, L. R.; ALFONSI, R. R.; CARAMORI, P. H., SWART, S. Balanços hídricos climáticos do Brasil. ESALQ/USP: PIRACICABA. In: CD-ROOM, 1999.

SILVA, A. L. B.; ALBUQUERQUE FILHO, J. L.; BREVEGLIERI, F. C.; FILIPOV, M.; SOARES, L. Water table oscilation due to hidroelectric dam reservoir impoundment in São Paulo State, Brazil. In: PROCEEDINGS EIGHTH INTERNATIONAL CONGRESSInternational Association for Engineering Geology and the Environment. 8., 1998, Vancouver. Anais...Vancouver: Balkema, 1998. p. 2367-2372.

SMITH, S. E. General impacts of Aswan High Dam. Journal of Water Resources Planning and Management, New York, v. 112, n. 4, p. 551-572, oct. 1986.

SONDOTÉCNICA S. A. Sistema produtor Alto Tietê: estudo de impacto ambiental. São Paulo, 1996, 2 v.

SOREK, S.; ADAR, E. M.; ISSAR, A. S. Modeling of flow pattern in shallow aquifer affected by reservoirs. II. Methods of estimating flow parameters using environmental tracers. Transport in Porous Media, Dordrecht, n. 8, p. 21-35, 1992.

SOREK, S.; ADAR, E. M.; ISSAR, A. S.; GEV, I. Modeling of flow pattern in shallow aquifer affected by reservoirs I. Evaluation of the flow system by environmental tracers. Transport in Porous Media, Dordrecht, n. 8, p. 1-20, 1992.

SUGUIO, K.; FÚLFARO, V. J.; COUTINHO, J. M. V. Tipos de contatos e estruturas sedimentares associadas da bacia de São Paulo. In: Congresso Brasileiro de Geologia, 25., 1971, São Paulo. Atas...São Paulo: SBG, 1971. v.2. p. 215-218.

TANG, CH. \& KONDOH, A. Regional Groundwater with GIS. In: INTERNATIONAL GEOLOGICAL CONGRESS, 30 ${ }^{\text {th }}, 1996$, Beijing, China. Abstracts...Beijing: 1996. v.1. n. J-5-8, 03923, 3568. 471p.

TEIXEIRA, A. L. A. \& CHRISTOFOLETTI, A. Sistemas de Informação geográfica. Dicionário ilustrado. São Paulo: Editora Hucitec. 1997. 243 p.

THEODOROVICZ, A.; YAMATO, A.; TAKAHASHI, A. T.; VASCONCELOS, C. S.; SANTARÉM, P. C.; SILVA, V. A. Projeto Santa Isabel/Mogi das Cruzes/Mauá Relatório Final. Companhia de Pesquisas de Recursos Minerais. Secretaria do Estado 
de Ciência, Tecnologia e Desenvolvimento Econômico. Programa de Desenvolvimento de Recursos Minerais - Pró-Minério. v. I e II. 1990.

THORNTHWAITE, C. W. An approach toward a rational classification of climate. Geogr. Rev., New York, v. 38, p. 55-94. 1948.

TOGNON, A. A. Glossário de termos técnicos de geologia de engenharia. Glossário. São Paulo: ABGE. 1985. 139 p.

TRESCOTT, P. C.; PINDER, G. F.; LARSON, S. P. Finite difference model for aquifer simulation in two dimensions with results of numerical experiments. U. S. Geological Survey, Washington, Book 7, chapter 01, 1976.

TSOU, M. S. \& WHITTERMORE, D. O. User interface for groundwater modeling: ArcView Extension. Journal of Hydrologic Engineering, New York, 6, n. 3, p. 251258, 2001.

TUCCI, C. E. M. Evaporação e evapotranspiração. In: TUCCI, C. E. M \& BELTRAME, L. F. S. Hidrologia. Editoras da USP e UFRGS, 1993. cap. 7.

van EVERDINGEN, R. O. The influence of the South Saskatchewan Reservoir on the local groundwater regime. A prognosis. Geological Survey of Canada, Ottawa. Paper 65-69. 85 p, 1968.

van EVERDINGEN, R. O. Influence of the South Saskatchewan reservoir (Canada) on piezometric levels in underlying bedrock aquifers. Journal of Hydrology, Amsterdam, v. 5, p. 351-359, 1967.

VASILIEV, O. F. System modeling of the interaction between surface and ground waters in problems of hydrology. Hydrological Sciences Journal, Oxford, v. 32, n. 3, p. 297-311, set. 1987.

VILLA NOVA, N. A.; BARBIERI, V.; SCARDUA, R. Evapotranspiração e evaporação: principais métodos de estimativa climatológica segundo as recomendações da FAO (1979). Piracicaba, 1980. Departamento de física e meteorologia - ESALQ/USP. Piracicaba, SP. p. 12. 
WARZOCHA, J. L. \& REEVE, A. S. Construction of a regional ground-water flow model for the glacial lake Agassiz peatland using GIS as a data management tool. In: GEOLOGICAL SOCIETY OF AMERICA. ANNUAL MEETING AND EXPOSITION. 1998, Toronto, Canadá. Abstracts...Toronto. 1998. A-119p.

WATKINS, D. W.; McKINNEY, D. C.; MAIDMENT, D. R.; LIN, M. D. Use of geographic information systems in ground-water flow modeling. Journal of Water Resources Planning Management, New York, v. 122, n. 2, p. 88-96, 1996.

WEISS, E. J. \& WILLIAMSON, A. K. Subdivision of thick sedimentary units into layers for simulation of ground-water flow. Ground Water, Dublin, v.6, n.23, p. 767-774, 1985.

WESSELING, J. Seepage. In: INTERNATIONAL INSTITUTE FOR LAND RECLAMATION AND IMPROVEMENT - ILRI. Drainage principles and application: theories of field drainage and watershed. Wageningem: ILRI, 1979. v. 2, cap. 13, p. 189-215, 1. ed. Publicação16.

WINTER, T. C. The interaction of lakes with vereably satured porous media. Water Resources Research, Washington, v. 19, n. 5, p. 1203-1218, oct. 1983.

WINTER, T. C. Numerical simulation of steady state three-dimensional groundwater flow near lakes. Water Resources Research, Washington, v. 14, n. 2, p. 245-254, 1978.

WINTER, T. C. Numerical simulation analysis of the interaction of lakes and ground water. Geological Survey Professional, Washington, paper 1001, 44 p, 1976. 


\section{ANEXO A}

Sondagens a trado realizadas na área de influência do reservatório de Biritiba-Mirim 
Localização, profundidade do nível d'água e carga hidráulica das sondagens a trado realizadas na bacia de contribuição do reservatório de Biritiba-Mirim (Dez/1999).

\begin{tabular}{|c|c|c|c|c|c|c|}
\hline \multirow{2}{*}{$\begin{array}{c}\mathrm{N}^{0} \mathrm{da} \\
\text { Sondagem }\end{array}$} & \multicolumn{3}{|c|}{ Coordenadas UTM (m) } & \multirow{2}{*}{$\begin{array}{l}\text { Unidades } \\
\text { geológicas* }\end{array}$} & \multirow{2}{*}{$\begin{array}{l}\text { Profundidade do } \\
\text { nível d'água (m) }\end{array}$} & \multirow{2}{*}{$\begin{array}{l}\text { Carga hidráulica } \\
\qquad(\mathrm{m})\end{array}$} \\
\hline & $x$ & Y & Z & & & \\
\hline SB - 01 & 389520 & 7388505 & 765,0 & PEe11 & 4,1 & 760,9 \\
\hline SB - 02 & 389771 & 7387247 & 772,0 & $\mathrm{A \gamma O}+1$ & 9,4 & 762,7 \\
\hline$S B-03$ & 388472 & 7388369 & 762,0 & Qha & 5,1 & 756,9 \\
\hline SB - 04 & 390665 & 7388797 & 770,5 & $\mathrm{~A} \gamma \mathrm{O}+1$ & 6,9 & 763,6 \\
\hline$S B-05$ & 391592 & 7389386 & 759,0 & Qha & 3,9 & 755,1 \\
\hline$S B-06$ & 391380 & 7388724 & 772,0 & $\mathrm{~A} \gamma \mathrm{O}+1$ & 9,4 & 762,7 \\
\hline SB -07 & 390549 & 7385670 & 775,0 & PEe11 & 3,8 & 771,3 \\
\hline$S B-08$ & 389450 & 7385441 & 773,0 & PEe11 & 6,8 & 766,2 \\
\hline SB - 09 & 389731 & 7383952 & 775,0 & Peү9 & 6,3 & 768,7 \\
\hline SB -10 & 386444 & 7383045 & 772,0 & $\mathrm{~A} \gamma 0+1$ & 2,3 & 769,7 \\
\hline SB -11 & 388702 & 7381227 & 773,0 & $\mathrm{~A} \gamma 0+1$ & 1,4 & 771,6 \\
\hline SB -12 & 388828 & 7379856 & 780,0 & $\mathrm{~A} \gamma \mathrm{O}+1$ & 3,8 & 776,2 \\
\hline SB - 13 & 388504 & 7383728 & 764,5 & Pe 9 & 2,7 & 761,8 \\
\hline SB - 14 & 390195 & 7382975 & 775,0 & $\mathrm{~A} \gamma \mathrm{O}+1$ & 6,2 & 768,8 \\
\hline SB - 15 & 389362 & 7385959 & 770,0 & PEe11 & 7,4 & 762,6 \\
\hline SB -16 & 387942 & 7382702 & 773,0 & Pe 9 & 4,4 & 768,6 \\
\hline SB - 17 & 388640 & 7387025 & 760,0 & PEe11 & 7,7 & 752,3 \\
\hline SB - 18 & 392064 & 7381949 & 770,0 & $\mathrm{~A} \gamma \mathrm{O}+1$ & 3,8 & 766,2 \\
\hline SB - 19 & 392499 & 7383562 & 775,0 & Pe 10 & 4,4 & 770,7 \\
\hline SB - 20 & 392357 & 7384718 & 783,0 & Peү5 & 3,4 & 779,6 \\
\hline SB - 21 & 391669 & 7383109 & 763,0 & Qha & 3,9 & 759,1 \\
\hline
\end{tabular}

*PEe11: Gnaisses Bandados (com budins de metabásicos e de cálcio silicatados)

A 0+1: Migmatitos Heterogêneos (gnaises graniticos migmatizados e corpos de biotititos)

Qha: Sedimentos aluvionares

Per9: Granito Taiaçupeba (estrutura gnáissica milonítica, granulação média, cinza)

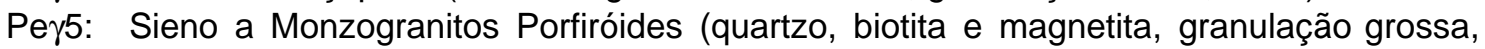
róseo) 


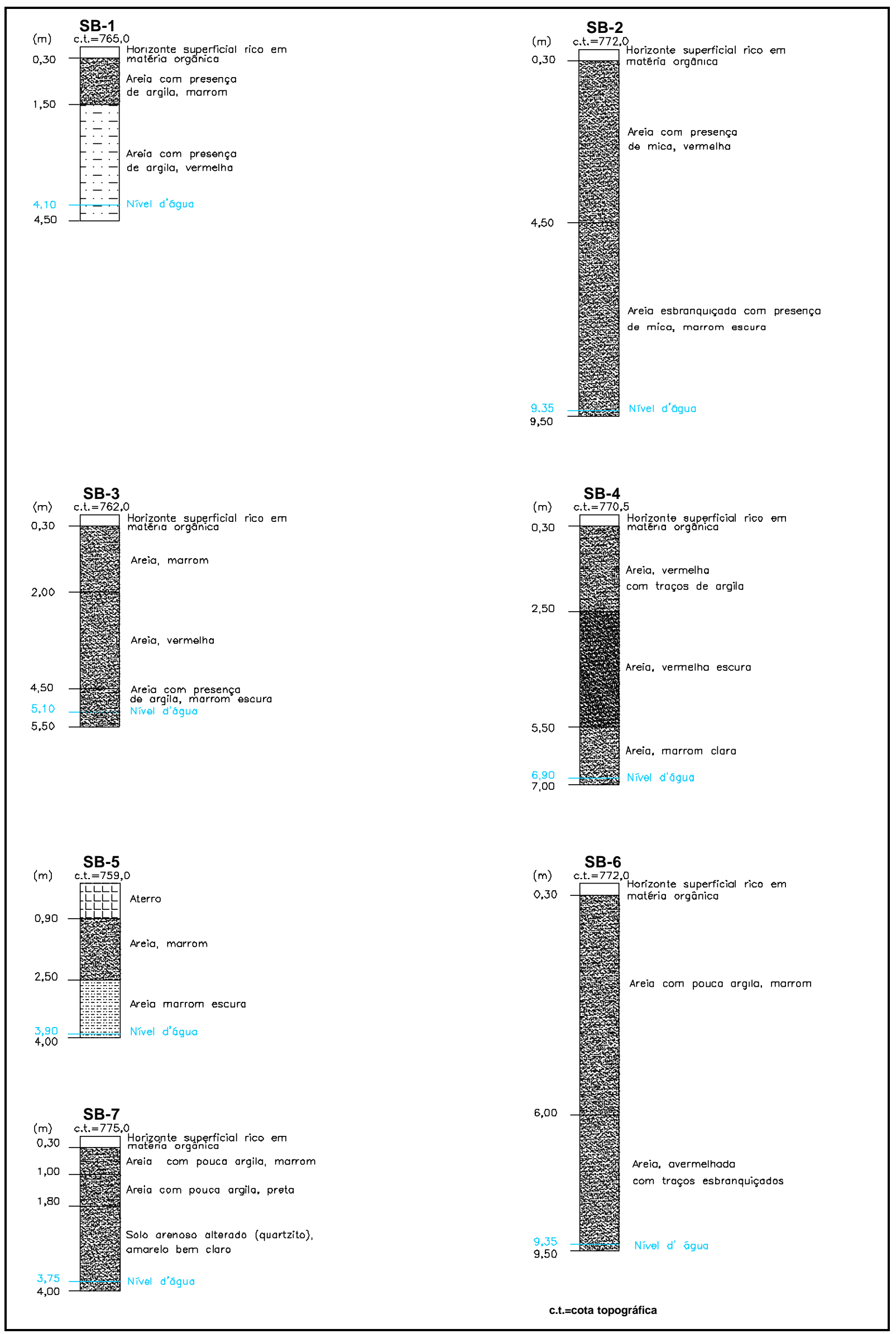


SB-8

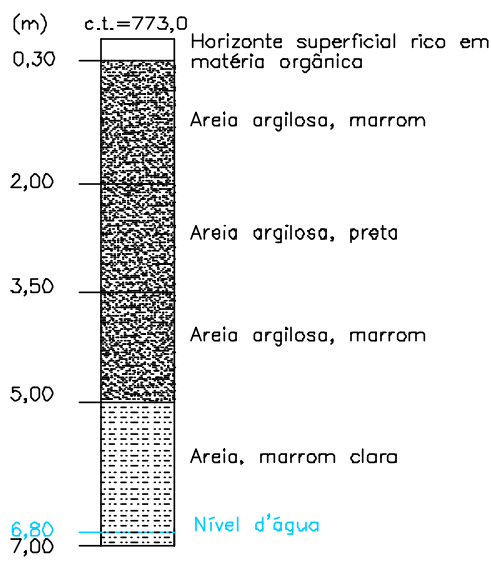

SB-10

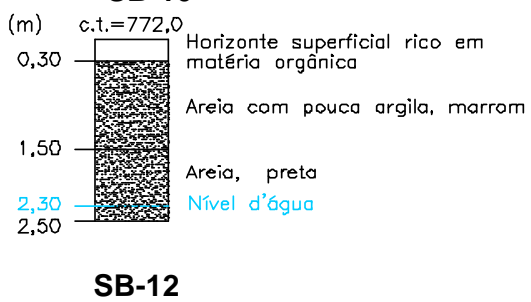

(m) c.t. $=780,0$ Horizonte superficial rico em

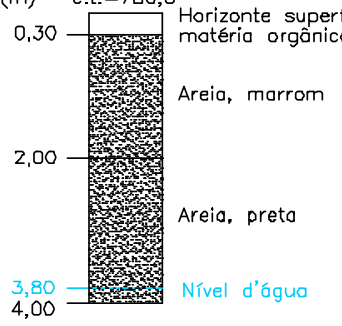

SB-9

(m) c.t. $=775,0$

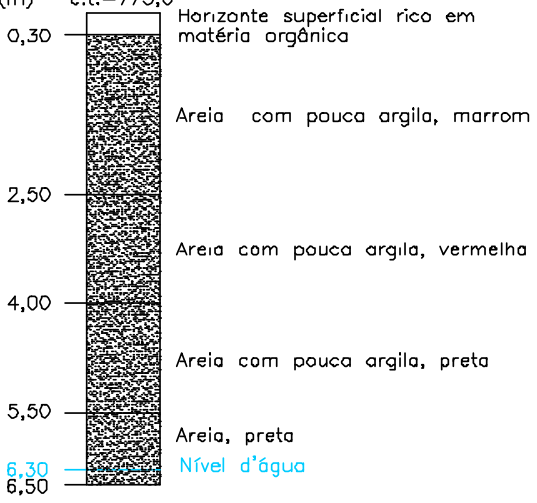

SB-11

(m) c.t. $=773.0$ Horizonte superficial rico em $0,30-$ matéria orgônica

. 1 Areia, marrom escura

1,00 Areia, amarelo claro

1,40 1,50

SB-13

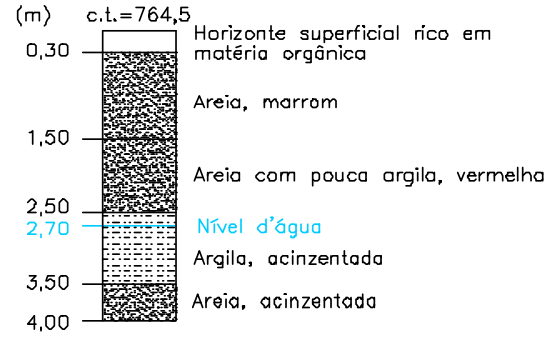

SB-14

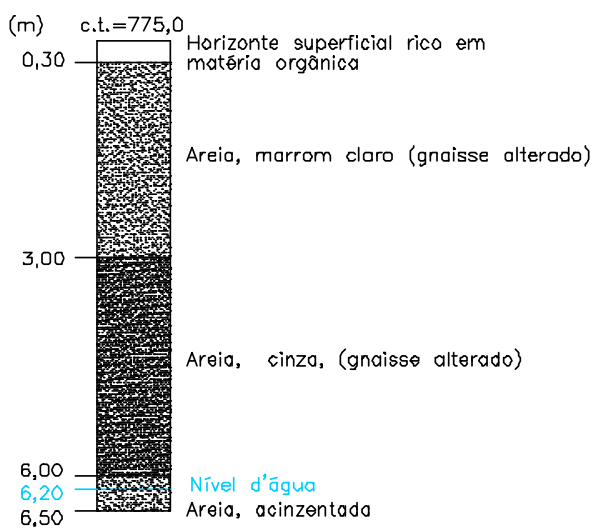




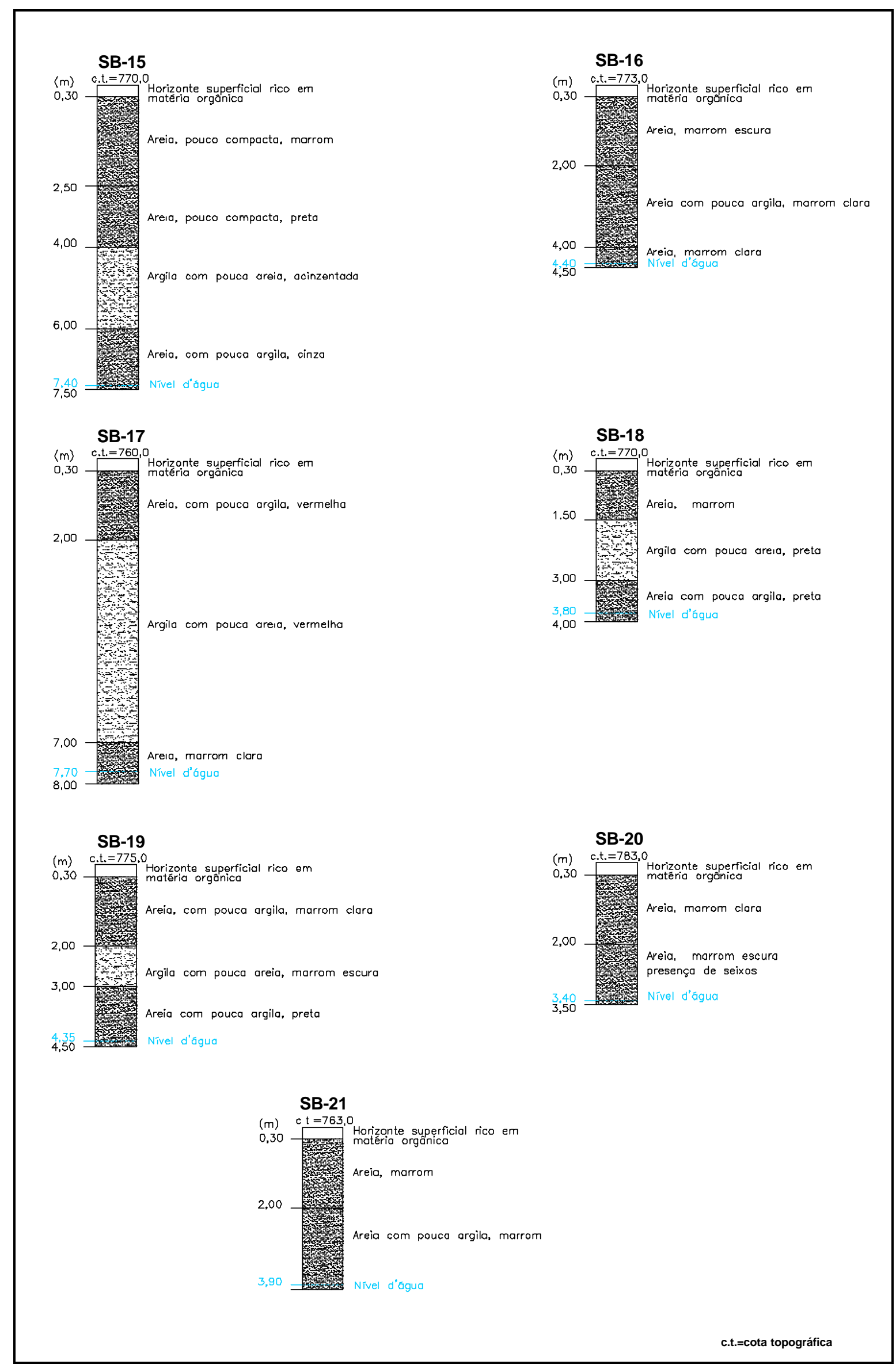




\section{ANEXO B}

Dados do cadastramento de poços realizado em novembro/dezembro 1999 


\begin{tabular}{|c|c|c|c|c|c|c|c|c|c|c|c|c|c|}
\hline \multirow{3}{*}{$\begin{array}{l}N^{0} \text { do } \\
\text { Poço }\end{array}$} & \multirow{3}{*}{$\begin{array}{c}\text { Folha } \\
\text { Topográfica } \\
\text { EMPLASA }\end{array}$} & \multirow{3}{*}{ Local } & \multirow{3}{*}{ Proprietário } & \multirow{2}{*}{\multicolumn{3}{|c|}{ Coordenadas UTM (m) }} & \multirow{3}{*}{$\begin{array}{l}\text { Uso da } \\
\text { Água }\end{array}$} & \multirow{2}{*}{\multicolumn{2}{|c|}{ Profundidade $(\mathrm{m})$}} & \multicolumn{4}{|c|}{ Propriedades } \\
\hline & & & & & & & & & & \multicolumn{2}{|c|}{ Temperatura $\left({ }^{\circ} \mathrm{C}\right)$} & \multirow{2}{*}{$\mathrm{pH}$} & \multirow{2}{*}{$\begin{array}{c}\text { C.E. } \\
(\mu \mathrm{S} / \mathrm{cm})\end{array}$} \\
\hline & & & & $\mathrm{x}$ & Y & Z & & Poço & N.A. ${ }^{1}$ & $\mathrm{Ar}$ & Água & & \\
\hline BM - 01 & Sogo & Sítio & Inez & 390397 & 7389799 & 795,0 & doméstico & 19,3 & 17,30 & 14 & 19 & 7,0 & 144 \\
\hline $\mathrm{BM}-02$ & Sogo & Bairro do Sogo & - & 390847 & 7389534 & 770,0 & doméstico & 12,0 & 11,12 & - & 19 & 7,0 & 149 \\
\hline $\mathrm{BM}-03$ & Sogo & Sito Santo Antônio & José A.P. Donizete & 391310 & 7389622 & 766,0 & doméstico & 10,1 & 7,39 & - & 19 & 7,0 & 151 \\
\hline $\mathrm{BM}-04$ & Cruz do Alto & Jardim dos Eucaliptos & Marcos A. Evangelista & 393146 & 7390200 & 792,0 & doméstico & 22,7 & 21,79 & 13 & 19 & 7,0 & 105 \\
\hline BM -05 & Cruz do Alto & Granja Ito & Granja Ito & 393567 & 7389877 & 783,0 & múltiplo & 6,0 & 2,89 & 11 & 17 & 6,5 & 430 \\
\hline $\mathrm{BM}-06$ & Cruz do Alto & Sítio Yamamoto & Edson Yamamoto & 393179 & 7389734 & 767,0 & doméstico & 4,9 & 3,17 & 12 & 18 & 7,0 & 93 \\
\hline $\mathrm{BM}-07$ & Cruz do Alto & Sítio Yamane & Takemure Yamane & 393283 & 7389468 & 807,0 & doméstico & 24,4 & 23,37 & 11 & 19 & 7,0 & 44 \\
\hline $\mathrm{BM}-08$ & Cruz do Alto & Sítio Georgio & A. Sade & 392999 & 7388643 & 775,0 & doméstico & 6,1 & 2,69 & 12 & 18 & 7,0 & 63 \\
\hline BM - 09 & Cruz do Alto & Fazenda Velha & Massar Takeshita & 393323 & 7388936 & 798,0 & - & 8,4 & 7,60 & 12 & 18 & 7,0 & 161 \\
\hline $\mathrm{BM}-10$ & Cruz do Alto & Estrada Sertãozinho & Hiromi Makiama & 392379 & 7389607 & 762,0 & doméstico & 4,1 & 2,29 & 12 & 18 & 7,0 & 149 \\
\hline $\mathrm{BM}-11$ & Cruz do Alto & - & Wilson P. de Almeida & 392144 & 7387649 & 770,0 & - & 11,3 & 9,66 & 14 & 18 & 7,0 & 74 \\
\hline $\mathrm{BM}-12$ & Sogo & - & Adelino Florine & 391571 & 7387646 & 763,0 & doméstico & 3,9 & 3,20 & 15 & 18 & 7,0 & 54 \\
\hline $\mathrm{BM}-13$ & Cruz do Alto & Chácara do Zé Maria & José Maria & 391900 & 7387152 & 767,0 & doméstico & 6,2 & 5,56 & - & - & - & - \\
\hline BM - 14 & Sogo & Illha do Carcará & José C.F. Marcondes & 390808 & 7387333 & 772,0 & doméstico & 10,7 & 9,49 & 15 & 19 & 7,0 & 65 \\
\hline $\mathrm{BM}-15$ & Sogo & Sítio Pitanga & Eduardo Schubacius & 391009 & 7387121 & 761,0 & doméstico & 9,3 & 7,00 & - & - & - & - \\
\hline $\mathrm{BM}-16$ & Biritiba Açu & Estrada da Paz Paraiso & Sílvio & 391533 & 7386576 & 770,0 & doméstico & 6,1 & 5,30 & 16 & 19 & 7,0 & 44 \\
\hline BM -17 & Sogo & Sítio Mario Takuma & Mário Takuma & 390183 & 7387828 & 758,0 & doméstico & 5,9 & 3,94 & 18 & 19 & 6,5 & 163 \\
\hline $\mathrm{BM}-18$ & Sogo & Sítio Sertãonzinho & Takakua & 390308 & 7388196 & 764,0 & doméstico & 8,6 & 7,21 & 20 & 19 & 7,0 & 49 \\
\hline BM - 19 & Sogo & (casa desabitada) & Getúlio & 389082 & 7387241 & 776,0 & - & 12,1 & 7,96 & 18 & 19 & 7,5 & 280 \\
\hline $\mathrm{BM}-20$ & Biritiba Açu & Sítio do Pascoal & José P. Viana & 389793 & 7386655 & 763,0 & doméstico & 5,5 & 4,08 & 18 & 18 & 7,0 & 34 \\
\hline $\mathrm{BM}-21$ & Biritiba Açu & Sítio do Suri & - & 390244 & 7387025 & 765,0 & doméstico & 4,4 & 2,29 & 15 & 18 & 7,0 & 39 \\
\hline $\mathrm{BM}-22$ & Biritiba Açu & Fazenda Soledad & Albino A. Figuereido & 388837 & 7384453 & 762,0 & doméstico & 5,8 & 4,71 & 16 & 18 & 6,5 & 144 \\
\hline $\mathrm{BM}-23$ & Sogo & Sítio do Vivaldo & Vivaldo B. Campos & 387739 & 7388612 & 765,0 & doméstico & 16,8 & 14,64 & 18 & 16 & 7,0 & 177 \\
\hline BM - 24 & Sogo & Estrada do Canário & Francisca C.O. Fernandes & 386742 & 7388185 & 765,0 & doméstico & 2,4 & 1,74 & - & - & - & - \\
\hline $\mathrm{BM}-25$ & Sogo & Estrada do Gavião & Luiz D. da Silva & 386810 & 7387786 & 770,0 & doméstico & 14,0 & 12,44 & 19 & 18 & 7,0 & 147 \\
\hline $\mathrm{BM}-26$ & Sogo & Sítio Alá & Antônio L. Alves & 388582 & 7388014 & 749,0 & doméstico & 3,6 & 2,33 & 20 & 19 & 7,0 & 55 \\
\hline BM - 27 & Sogo & Sítio do Delegado & Francisco Stucchi & 387841 & 7387792 & 765,0 & doméstico & 3,4 & 1,82 & 21 & 18 & 7,0 & 158 \\
\hline $\mathrm{BM}-28$ & Sogo & Estrada do Gavião & Júlio & 387397 & 7387822 & 770,0 & doméstico & 18,4 & 16,91 & 20 & 19 & 11,0 & 660 \\
\hline
\end{tabular}

${ }^{1}:$ N.A. = Nível de Água

2: Poço tubular

- : Ausência de dado

(continua) 
(continuação)

\begin{tabular}{|c|c|c|c|c|c|c|c|c|c|c|c|c|c|}
\hline \multirow{3}{*}{$\begin{array}{l}N^{0} \text { do } \\
\text { Poço }\end{array}$} & \multirow{3}{*}{$\begin{array}{c}\text { Folha } \\
\text { Topográfica } \\
\text { EMPLASA }\end{array}$} & \multirow{3}{*}{ Local } & \multirow{3}{*}{ Proprietário } & \multirow{2}{*}{\multicolumn{3}{|c|}{ Coordenadas UTM (m) }} & \multirow{3}{*}{$\begin{array}{l}\text { Uso da } \\
\text { Água }\end{array}$} & \multirow{2}{*}{\multicolumn{2}{|c|}{ Profundidade $(\mathrm{m})$}} & \multicolumn{4}{|c|}{ Propriedades } \\
\hline & & & & & & & & & & \multicolumn{2}{|c|}{ Temperatura $\left({ }^{\circ} \mathrm{C}\right)$} & \multirow[t]{2}{*}{$\mathrm{pH}$} & \multirow{2}{*}{$\begin{array}{c}\text { C.E. } \\
(\mu S / \mathrm{cm})\end{array}$} \\
\hline & & & & $x$ & Y & Z & & Poço & N.A. ${ }^{1}$ & $\mathrm{Ar}$ & Água & & \\
\hline BM - 29 & Sogo & Estrada do Gavião & Isac S. dos Santos & 387029 & 7387247 & 768,0 & doméstico & 4,2 & 2,85 & 21 & 19 & 7,0 & 200 \\
\hline $\mathrm{BM}-30$ & Sogo & Estrada do Gavião & Paulino Kobaiashi & 386488 & 7387616 & 762,0 & doméstico & 4,8 & 2,50 & 19 & 18 & 7,0 & 90 \\
\hline $\mathrm{BM}-31$ & Biritiba Açu & Sítio São Joaquim & Fermina R. da Siqueira & 388598 & 7384566 & 759,0 & doméstico & 3,9 & 3,18 & 20 & 21 & 6,5 & 36 \\
\hline $\mathrm{BM}-32$ & Biritiba Açu & Sítio Asano & Keize Asano & 388216 & 7384926 & 770,0 & doméstico & 9,2 & 6,67 & 21 & 20 & 7,0 & 134 \\
\hline $\mathrm{BM}-33$ & Biritiba Açu & Sítio Codo & Antônio Codo & 387704 & 7385237 & 759,0 & doméstico & 5,1 & 3,22 & 20 & 20 & 7,0 & 75 \\
\hline $\mathrm{BM}-35$ & Biritiba Açu & Chácara do Lago & José E. do Lago & 387472 & 7385871 & 768,0 & doméstico & 4,7 & 3,60 & 19 & 20 & 6,5 & 81 \\
\hline $\mathrm{BM}-36$ & Biritiba Açu & Sítio Casu Lide & Casu Lide & 387207 & 7385679 & 770,0 & - & 4,1 & 2,45 & 19 & 19 & 7,0 & 62 \\
\hline $\mathrm{BM}-37$ & Biritiba Açu & Sítio Oeno & Iroiko Oeno & 387077 & 7384911 & 770,0 & - & 6,1 & 4,40 & 18 & 19 & 7,0 & 141 \\
\hline $\mathrm{BM}-38^{2}$ & Biritiba Açu & Hotel Fazenda (SEPA' & Comendador C.O. Guimarães & 387676 & 7384489 & 780,0 & doméstico & 36,8 & 6,94 & 19 & 20 & 6,5 & 61 \\
\hline $\mathrm{BM}-39$ & Biritiba Açu & Sítio Yoshida & José Yoshida & 387655 & 7383758 & 785,0 & doméstico & 4,9 & 4,45 & 20 & 18,5 & 6,5 & 164 \\
\hline $\mathrm{BM}-40$ & Biritiba Açu & Sítio Obara & Yoshitaki Obara & 387147 & 7384036 & 772,0 & doméstico & 7,6 & 5,70 & 21 & 19 & 7,0 & 171 \\
\hline $\mathrm{BM}-41$ & Biritiba Açu & Sítio Sercia & Sr. Gerson & 386755 & 7384018 & 785,0 & doméstico & 22,5 & 21,45 & 22 & 20 & 6,5 & 60 \\
\hline $\mathrm{BM}-42$ & Biritiba Açu & Biritiba Ussú km 23 & José Beraldo & 386760 & 7383299 & 765,0 & doméstico & 3,2 & 1,90 & 23 & 20 & 6,5 & 153 \\
\hline $\mathrm{BM}-45$ & Biritiba Açu & Sítio do km 25 & D. Maria Rosa & 387582 & 7382498 & 762,0 & doméstico & 6,1 & 5,50 & 23 & 19 & 6,5 & 77 \\
\hline $\mathrm{BM}-46$ & Faz. Vanguarda & Pesqueiro & Clemente Filho & 387484 & 7381795 & 770,0 & - & 6,8 & 5,25 & 23 & 20 & 6,5 & 72 \\
\hline $\mathrm{BM}-47$ & Faz. Vanguarda & Sítio Sequeta & Koiti Segueta & 387712 & 7382011 & 770,0 & doméstico & 13,6 & 12,60 & 21 & 19 & 6,5 & 80 \\
\hline $\mathrm{BM}-48$ & Faz. Vanguarda & Sítio Okubo & Toshio V. Okubo & 387869 & 7381367 & 770,0 & doméstico & 3,0 & 1,75 & 23 & 20 & 6,5 & 75 \\
\hline $\mathrm{BM}-49$ & Faz. Vanguarda & Est. Municipal Komatsu & Akira Komatsu & 388249 & 7380713 & 768,0 & doméstico & 7,4 & 4,20 & 22 & 19 & 6,5 & 69 \\
\hline $\mathrm{BM}-50$ & Faz. Vanguarda & Sítio Sugueda & Ricardo Sugueda & 388159 & 7381993 & 759,0 & doméstico & 6,9 & 5,20 & 21 & 19 & 7,0 & 64 \\
\hline $\mathrm{BM}-51$ & Faz. Vanguarda & Sítio da Estrada Ito & Wilson T. Honda & 389031 & 7382182 & 770,0 & doméstico & 5,4 & 2,45 & 20 & 19 & 6,5 & 60 \\
\hline $\mathrm{BM}-52$ & Faz. Vanguarda & $\begin{array}{l}\text { Bairro Manoel } \\
\text { ferreira }\end{array}$ & Osvaldo D. Prado & 387962 & 7380923 & 768,0 & - & 2,8 & 1,01 & 20 & 19 & 6,5 & 123 \\
\hline $\mathrm{BM}-53$ & Faz. Vanguarda & Sítio & Umechi Kamegazawa & 389379 & 7381746 & 776,0 & doméstico & 8,9 & 6,70 & 20 & 19 & 6,5 & 41 \\
\hline $\mathrm{BM}-54$ & Faz. Vanguarda & Terras de Avão & José F. Rossi & 389461 & 7381198 & 765,0 & - & 5,9 & 3,00 & 19 & 19 & 6,5 & 47 \\
\hline $\mathrm{BM}-55$ & Faz. Vanguarda & Sítio & José J. Marques & 389452 & 7380287 & 757,0 & doméstico & 4,1 & 2,50 & 19 & 19 & 6,5 & 197 \\
\hline
\end{tabular}

1 : N.A. = Nível de Água

2 : Poço tubular

- : Ausência de dado

(continua) 
(continuação)

\begin{tabular}{|c|c|c|c|c|c|c|c|c|c|c|c|c|c|}
\hline \multirow{3}{*}{$\begin{array}{l}N^{0} \text { do } \\
\text { Poço }\end{array}$} & \multirow{3}{*}{$\begin{array}{c}\text { Folha } \\
\text { Topográfica }\end{array}$} & \multirow{3}{*}{ Local } & \multirow{3}{*}{ Proprietário } & \multirow{2}{*}{\multicolumn{3}{|c|}{ Coordenadas UTM (m) }} & \multirow{3}{*}{$\begin{array}{l}\text { Uso da } \\
\text { Água }\end{array}$} & \multirow{2}{*}{\multicolumn{2}{|c|}{ Profundidade $(m)$}} & \multicolumn{4}{|c|}{ Propriedades } \\
\hline & & & & & & & & & & \multicolumn{2}{|c|}{ Temperatura $\left({ }^{\circ} \mathrm{C}\right)$} & \multirow{2}{*}{$\mathrm{pH}$} & \multirow{2}{*}{$\begin{array}{l}\text { C.E. } \\
(\mu \mathrm{S} / \mathrm{cm})\end{array}$} \\
\hline & & & & $x$ & Y & Z & & Poço & N.A. ${ }^{1}$ & $\mathrm{Ar}$ & Água & & \\
\hline $\mathrm{BM}-56$ & Faz. Vanguarda & Sítio Moreira & Antônio Moreira & 390176 & 7382215 & 778,0 & doméstico & 6,1 & 3,80 & 24 & 20 & 6,5 & 122 \\
\hline $\mathrm{BM}-57$ & Faz. Vanguarda & Chácara Dona Nena & Carmem Zafra Jacinto & 390325 & 7381294 & 779,0 & doméstico & 7,1 & 5,00 & 23 & 19 & 6,5 & 110 \\
\hline BM - 58 & Faz. Vanguarda & Sítio Recanto do Sardinha & José M.P. Bonardy & 390715 & 7381546 & 776,0 & doméstico & 3,5 & 1,40 & 26 & 19 & 6,5 & 127 \\
\hline $\mathrm{BM}-59$ & Biritiba Açu & Sítio Lagoa Encantada & Paulo J. Campos & 390995 & 7382239 & 775,0 & - & 9,3 & 6,60 & 26 & 19 & 6,5 & 67 \\
\hline $\mathrm{BM}-60$ & Biritiba Açu & casa fechada & - & 390785 & 7382485 & 770,0 & - & 7,9 & 5,60 & 26 & 19 & 6,5 & 106 \\
\hline $\mathrm{BM}-61$ & Biritiba Açu & Sítio Del Bem & Narciso Del Bem & 391339 & 7383102 & 771,0 & doméstico & 4,0 & 1,90 & 27 & - & 6,5 & 22 \\
\hline $\mathrm{BM}-62$ & Biritiba Açu & Sítio Ticolinha & Nicola Akoramico & 391070 & 7383666 & 776,0 & doméstico & 6,5 & 3,90 & 23 & 20 & 8,5 & 560 \\
\hline $\mathrm{BM}-63$ & Biritiba Açu & Sítio Santa Catarina & Pedro Paulo & 389455 & 7383086 & 790,0 & doméstico & 1,5 & 0,45 & 21 & - & 6,5 & 45 \\
\hline $\mathrm{BM}-64$ & Biritiba Açu & Sítio Hayasaka & Hideo Hayasaka & 385745 & 7387671 & 780,0 & doméstico & 9,5 & 8,30 & 21 & 19 & 6,5 & 121 \\
\hline $\mathrm{BM}-65$ & Cruz do Alto & Sítio São Brás & Claudinei A. Raimundo & 392911 & 7387573 & 780,0 & - & 3,2 & 1,70 & 21 & 19 & 6,5 & 84 \\
\hline
\end{tabular}

${ }^{1}:$ N.A. = Nível de Água

2 : Poço tubular

- : Ausência de dado 


\section{ANEXO C}

Relação entre a carga hidráulica medida e a calibrada 


\begin{tabular}{|c|c|c|c|c|c|c|}
\hline \multirow{2}{*}{$\begin{array}{l}N^{\circ} \text { do } \\
\text { Poço }\end{array}$} & \multicolumn{3}{|c|}{ Coordenadas UTM (m) } & \multirow{2}{*}{$\begin{array}{l}\text { Carga hidráulica } \\
\text { Dez/99 }(\mathrm{m})\end{array}$} & \multirow{2}{*}{$\begin{array}{l}\text { Carga hidráulica } \\
\text { calibrada }(\mathrm{m})\end{array}$} & \multirow{2}{*}{$\begin{array}{l}\text { Diferença } \\
\text { (m) }\end{array}$} \\
\hline & $\mathrm{X}$ & $Y$ & Z & & & \\
\hline BM-01 & 390397 & 7389799 & 795,0 & 777,7 & 777,0 & $-0,6$ \\
\hline BM-02 & 390847 & 7389534 & 770,0 & 758,9 & 758,5 & $-0,4$ \\
\hline BM-03 & 391310 & 7389622 & 766,0 & 758,6 & 758,2 & $-0,3$ \\
\hline BM-04 & 393146 & 7390200 & 792,0 & 770,2 & 769,6 & $-0,3$ \\
\hline BM-05 & 393567 & 7389877 & 783,0 & 780,1 & 779,6 & $-0,5$ \\
\hline BM-06 & 393179 & 7389734 & 767,0 & 763,8 & 763,6 & $-0,1$ \\
\hline BM-07 & 393283 & 7389468 & 807,0 & 783,6 & 783,1 & $-0,1$ \\
\hline BM-08 & 392999 & 7388643 & 775,0 & 772,3 & 771,8 & $-0,4$ \\
\hline BM-09 & 393323 & 7388936 & 798,0 & 790,4 & 790,1 & $-0,3$ \\
\hline BM-10 & 392379 & 7389607 & 762,0 & 759,7 & 759,5 & $-0,2$ \\
\hline BM-11 & 392144 & 7387649 & 770,0 & 760,3 & 760,0 & $-0,2$ \\
\hline BM-12 & 391571 & 7387646 & 763,0 & 759,8 & 758,1 & $-1,8$ \\
\hline BM-13 & 391900 & 7387152 & 767,0 & 761,4 & 765,0 & $+3,6$ \\
\hline BM-14 & 390808 & 7387333 & 772,0 & 762,5 & 761,2 & $-1,3$ \\
\hline BM-15 & 391009 & 7387121 & 761,0 & 754,0 & 759,6 & $+5,6$ \\
\hline BM-16 & 391533 & 7386576 & 770,0 & 764,7 & 764,8 & $+0,1$ \\
\hline BM-17 & 390183 & 7387828 & 758,0 & 754,1 & 753,9 & $-0,2$ \\
\hline BM-18 & 390308 & 7388196 & 764,0 & 756,8 & 756,2 & $-0,6$ \\
\hline BM-19 & 389082 & 7387241 & 776,0 & 768,0 & 767,3 & $-0,7$ \\
\hline BM-20 & 389793 & 7386655 & 763,0 & 758,9 & 758,3 & $-0,6$ \\
\hline BM-21 & 390244 & 7387025 & 765,0 & 762,7 & 762,0 & $-0,6$ \\
\hline BM-22 & 388837 & 7384453 & 762,0 & 757,3 & 756,7 & $-0,6$ \\
\hline BM-23 & 387739 & 7388612 & 765,0 & 750,4 & 751,7 & $+1,4$ \\
\hline BM-24 & 386742 & 7388185 & 765,0 & 763,3 & 760,6 & $-2,7$ \\
\hline BM-25 & 386810 & 7387786 & 770,0 & 757,6 & 757,6 & $+0,0$ \\
\hline BM-26 & 388582 & 7388014 & 749,0 & 746,7 & 746,1 & $-0,6$ \\
\hline BM-27 & 387841 & 7387792 & 765,0 & 763,2 & 763,3 & $+0,2$ \\
\hline BM-28 & 387397 & 7387822 & 770,0 & 753,1 & 758,3 & $+5,1$ \\
\hline BM-29 & 387029 & 7387247 & 768,0 & 765,2 & 764,6 & $-0,4$ \\
\hline BM-30 & 386488 & 7387616 & 762,0 & 759,5 & 758,9 & $-0,6$ \\
\hline BM-31 & 388598 & 7384566 & 759,0 & 755,8 & 755,3 & $-0,5$ \\
\hline BM-32 & 388216 & 7384926 & 770,0 & 763,3 & 762,7 & $-0,7$ \\
\hline BM-33 & 387704 & 7385237 & 759,0 & 755,8 & 755,2 & $-0,6$ \\
\hline BM-34 & 387735 & 7386606 & 768,0 & 763,4 & 766,6 & $+3,2$ \\
\hline BM-35 & 387472 & 7385871 & 768,0 & 764,4 & 764,2 & $-0,2$ \\
\hline BM-36 & 387207 & 7385679 & 770,0 & 767,6 & 766,9 & $-0,4$ \\
\hline BM-37 & 387077 & 7384911 & 770,0 & 765,6 & 765,2 & $-0,5$ \\
\hline BM-38 & 387676 & 7384489 & 780,0 & 773,1 & 773,2 & 0,0 \\
\hline BM-39 & 387655 & 7383758 & 785,0 & 780,6 & 780,1 & $-0,6$ \\
\hline BM-40 & 387147 & 7384036 & 772,0 & 766,3 & 765,2 & $-1,1$ \\
\hline BM-41 & 386755 & 7384018 & 785,0 & 763,6 & 767,7 & $+4,1$ \\
\hline BM-42 & 386760 & 7383299 & 765,0 & 763,1 & 764,2 & $+0,9$ \\
\hline BM-43 & 387859 & 7383157 & 769,0 & 757,0 & 757,6 & $+0,6$ \\
\hline BM-44 & 388304 & 7383280 & 763,0 & 758,9 & 758,5 & $-0,2$ \\
\hline BM-45 & 387582 & 7382498 & 762,0 & 756,5 & 756,3 & $-0,5$ \\
\hline BM-46 & 387484 & 7381795 & 770,0 & 764,8 & 764,5 & $-0,4$ \\
\hline
\end{tabular}

(Continua) 
(Continuação)

\begin{tabular}{|c|c|c|c|c|c|c|}
\hline \multirow{2}{*}{$\begin{array}{l}N^{0} \text { do } \\
\text { Poço }\end{array}$} & \multicolumn{3}{|c|}{ Coordenadas UTM (m) } & \multirow{2}{*}{$\begin{array}{l}\text { Carga hidráulica } \\
\text { Dez/99 (m) }\end{array}$} & \multirow{2}{*}{$\begin{array}{l}\text { Carga hidráulica } \\
\text { calibrada (m) }\end{array}$} & \multirow{2}{*}{$\begin{array}{l}\text { Diferença } \\
\text { (m) }\end{array}$} \\
\hline & $\mathrm{X}$ & $Y$ & Z & & & \\
\hline BM-47 & 387712 & 7382011 & 770,0 & 757,4 & 757,7 & $+0,2$ \\
\hline BM-48 & 387869 & 7381367 & 770,0 & 768,3 & 767,5 & $-0,7$ \\
\hline BM-49 & 388249 & 7380713 & 768,0 & 763,8 & 763,6 & $-0,2$ \\
\hline BM-50 & 388159 & 7381993 & 759,0 & 753,8 & 756,3 & $+2,6$ \\
\hline BM-51 & 389031 & 7382182 & 770,0 & 767,6 & 767,1 & $-0,5$ \\
\hline BM-52 & 387962 & 7380923 & 768,0 & 767,0 & 766,8 & $-0,2$ \\
\hline BM-53 & 389379 & 7381746 & 776,0 & 769,3 & 769,0 & $-0,3$ \\
\hline BM-54 & 389461 & 7381198 & 765,0 & 762,0 & 761,4 & $-0,6$ \\
\hline BM-55 & 389452 & 7380287 & 757,0 & 754,5 & 757,5 & $+3,2$ \\
\hline BM-56 & 390176 & 7382215 & 778,0 & 774,2 & 773,9 & $-0,5$ \\
\hline BM-57 & 390325 & 7381294 & 779,0 & 774,0 & 773,8 & 0,0 \\
\hline BM-58 & 390715 & 7381546 & 776,0 & 774,6 & 772,9 & $-1,5$ \\
\hline BM-59 & 390995 & 7382239 & 775,0 & 768,4 & 768,7 & $+0,2$ \\
\hline BM-60 & 390785 & 7382485 & 770,0 & 764,4 & 764,1 & $-0,3$ \\
\hline BM-61 & 391339 & 7383102 & 771,0 & 769,1 & 768,2 & $-1,0$ \\
\hline BM-62 & 391070 & 7383666 & 776,0 & 772,1 & 772,1 & 0,0 \\
\hline BM-63 & 389455 & 7383086 & 790,0 & 789,6 & 789,4 & 0,0 \\
\hline BM-64 & 385745 & 7387671 & 780,0 & 771,7 & 771,4 & $-0,4$ \\
\hline BM-65 & 392911 & 7387573 & 780,0 & 778,3 & 778,2 & 0,0 \\
\hline $\mathrm{ME}^{1}$ & & & & & & $-0,1$ \\
\hline $\mathrm{MAE}^{2}$ & & & & & & $+0,8$ \\
\hline $\mathrm{RMS}^{3}$ & & & & & & $+1,5$ \\
\hline
\end{tabular}

${ }^{1}$ Erro Médio

${ }^{2}$ Erro Médio Absoluto

${ }^{3}$ Desvio padrão 


\section{ANEXO D}

Poços de monitoramento instalados na bacia de contribuição do reservatório de Biritiba-Mirim 


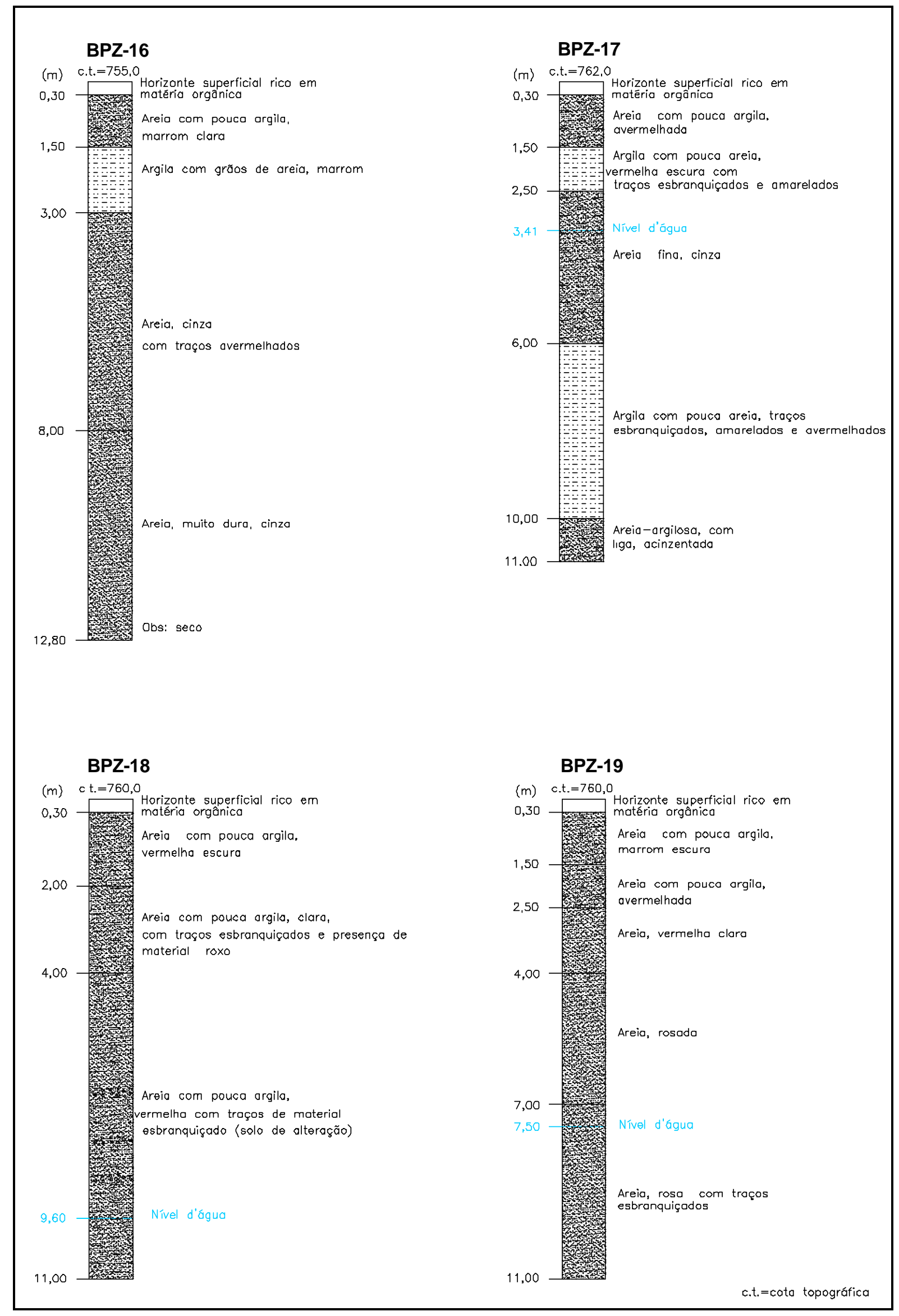




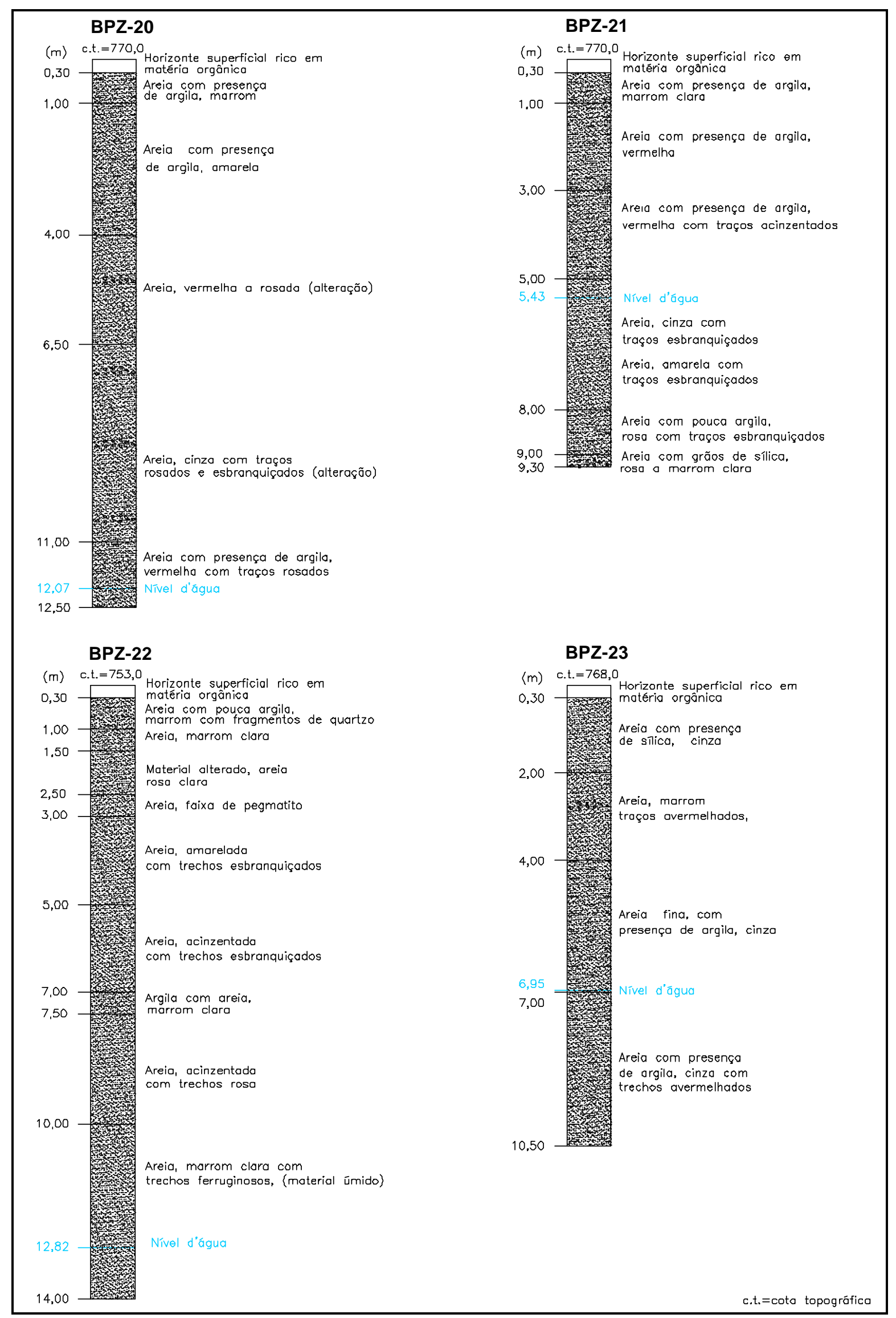




\section{BPZ-24}

(m) c.t. $=764,0$ Horizonte superficial rico em

$0.30 \longrightarrow$ matera

0,50 presenç com de argila, marrom

Argila, vermelho

4,00

5,00

Argila com presenço

de trechos arenosos esbranquiçados

Argila, rosa

com presença de mica

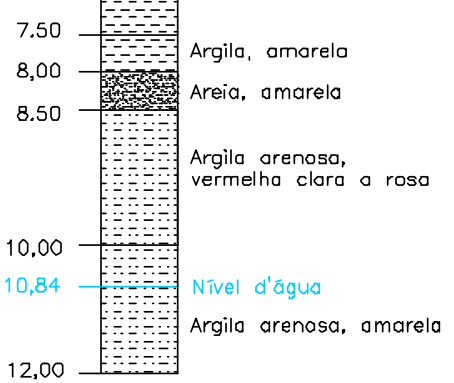

\section{BPZ-26}

(m) c.t. $=774,5$ Horizonte superficial rico em

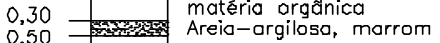

0,50 Argila com presença de areia, cinzo

1,00 1,

2,00 Argila, ocre

Argila com presença de areia. ocre, com traços

3,00 rosados e esbranquiçados

Areia com presença de argila ocre a overmelhada

5,00

, 00

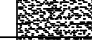

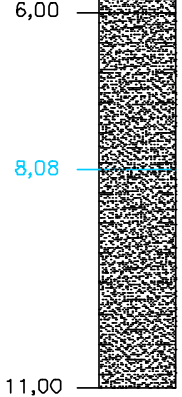

Areia com presença de argila $\theta$ mica, cinzo

Nivel d’águo

Areia com presença de argila

e mica. cinzo com trasos

róseos. cinzo com traços

\section{BPZ-25}

(m) c.t. $=763,5$ Horizonte superficial rico em

0.30 materia orgônica

Argila, preta

1,50

2,15 Nivel d'água

Areia com presença de argila, clara

3.00

presenço de argila, ocre

Areia com presença de

argila, ocre com traços vermelhos

e esbranquiçados

6,00

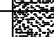

Areia -argilosa com presenca

de mica, vinho

Areia-argilosa com presença de mica, vermelho

Areia-argilosa com presença de mica, vermelha clara
BPZ-27

(m) c.t. $=765,0$ Horizonte superficial rico em

0,30 matéria orgânica

Areia com pouca argila, marrom

1,5

Argila com pouca areia, ocre

4,00

Areía com pouca argila,

amarela clara

6,98 Nivel d'água

Areia com pouca argila, vermelha (presença de material alterado)

8,00

Areia-argilosa, cinzo com traço rosados (presença de material alterado) 


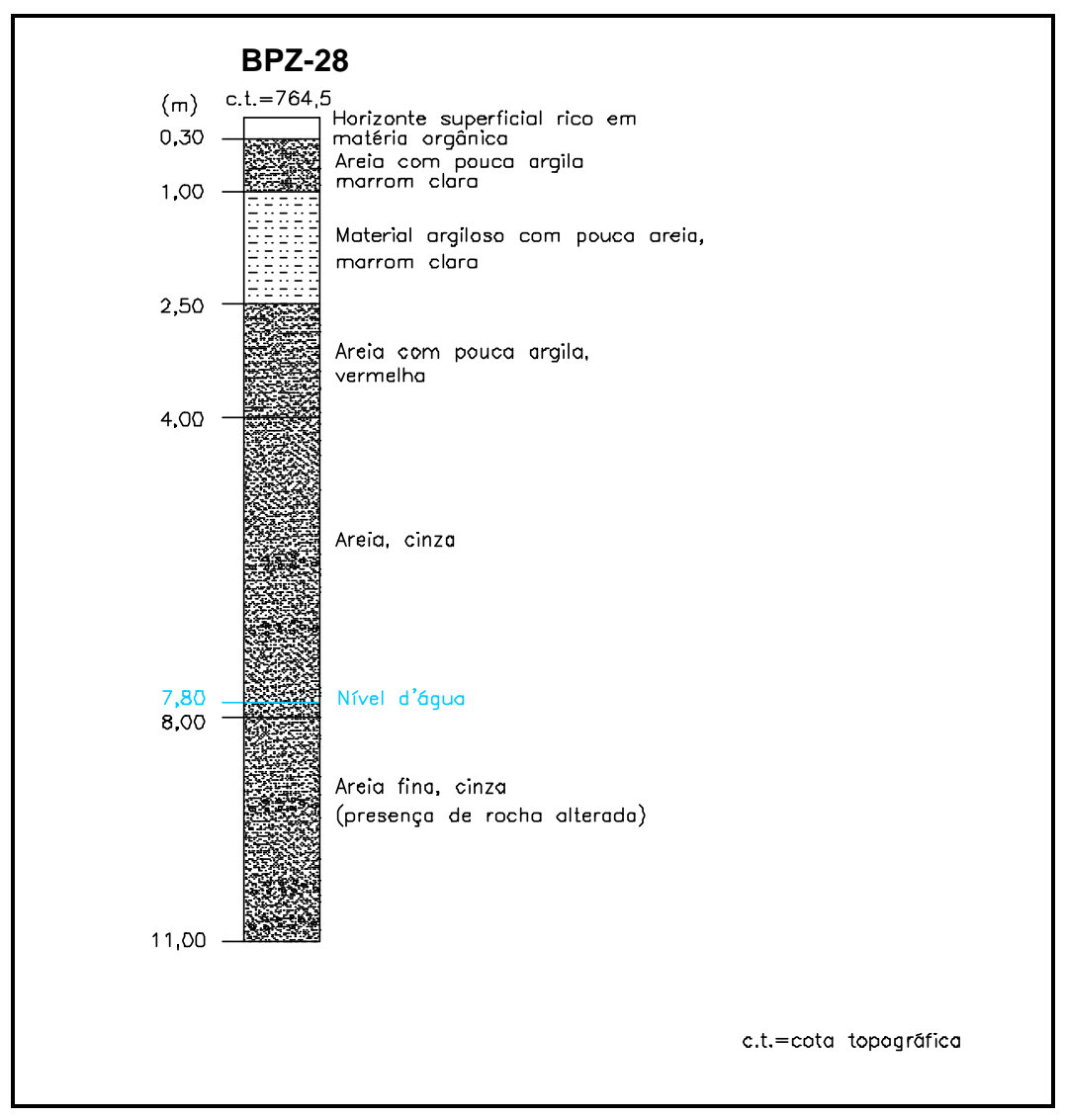




\section{ANEXO E}

Resultados dos testes de permeabilidade 


\section{ENSAIO DE PERMEABILIDADE}

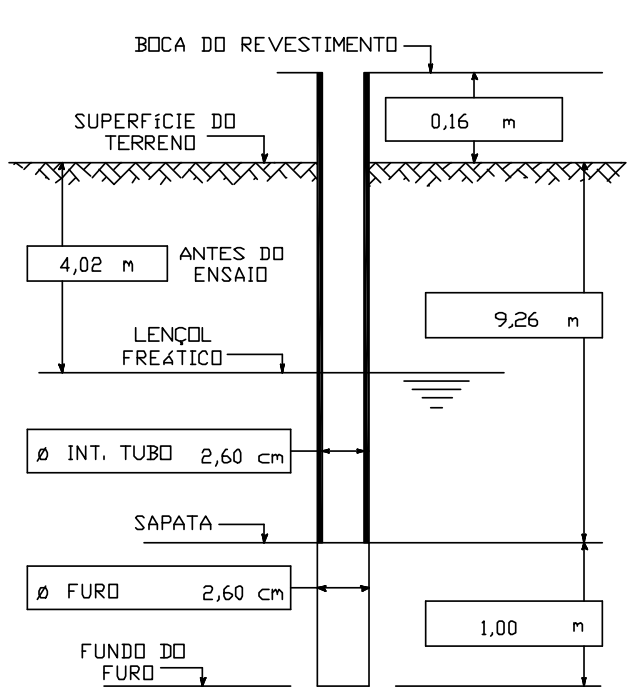

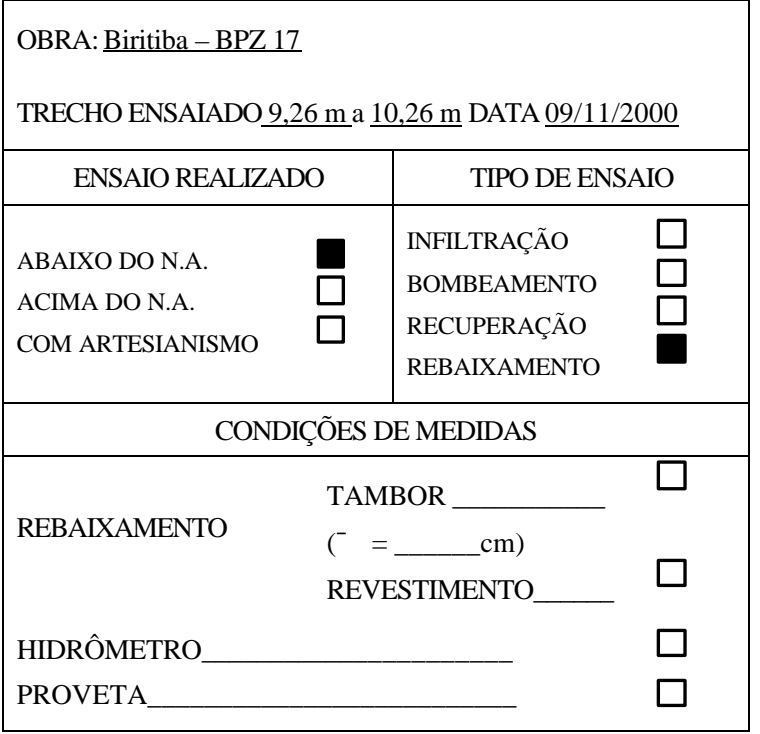

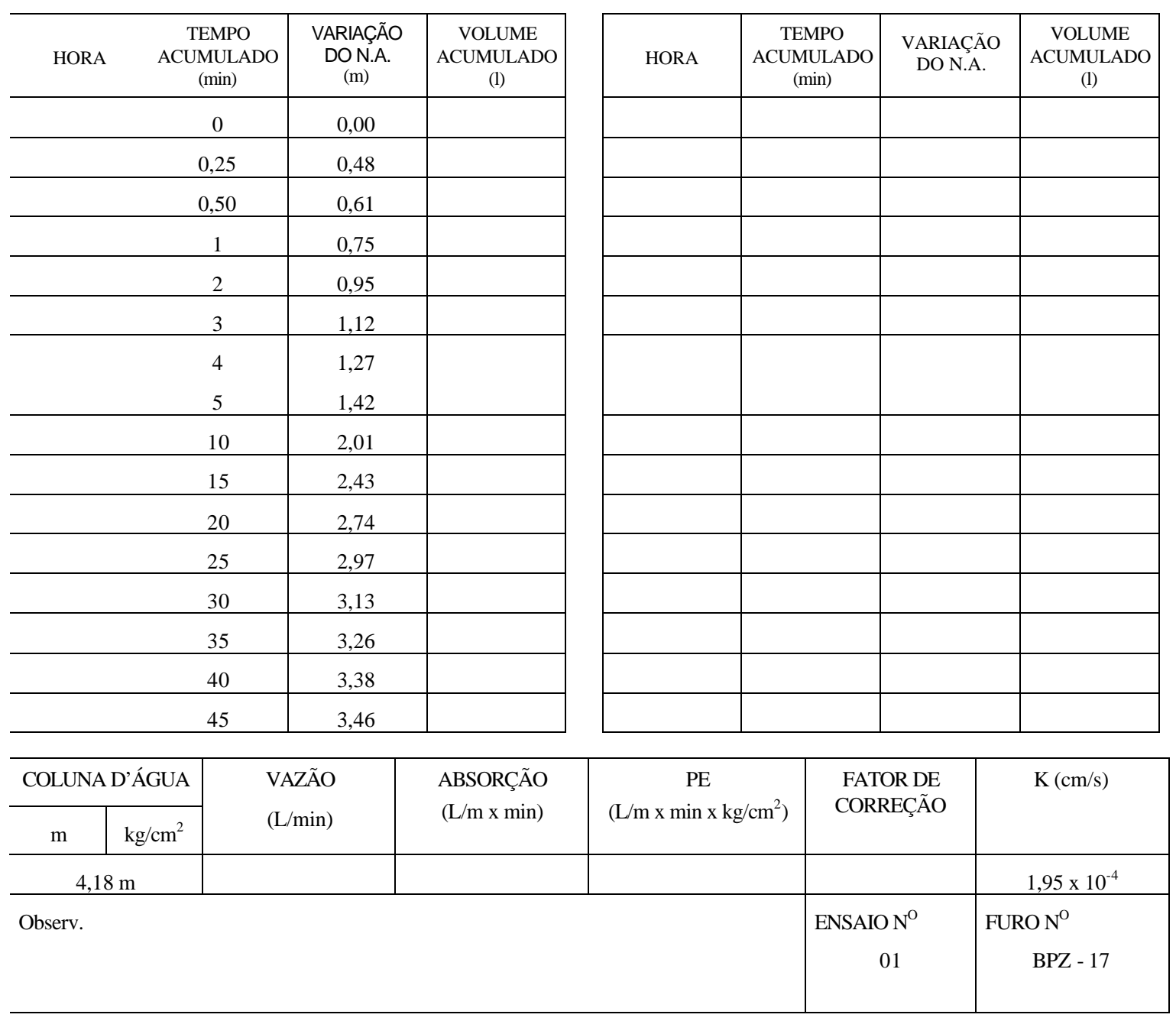




\section{ENSAIO DE PERMEABILIDADE}

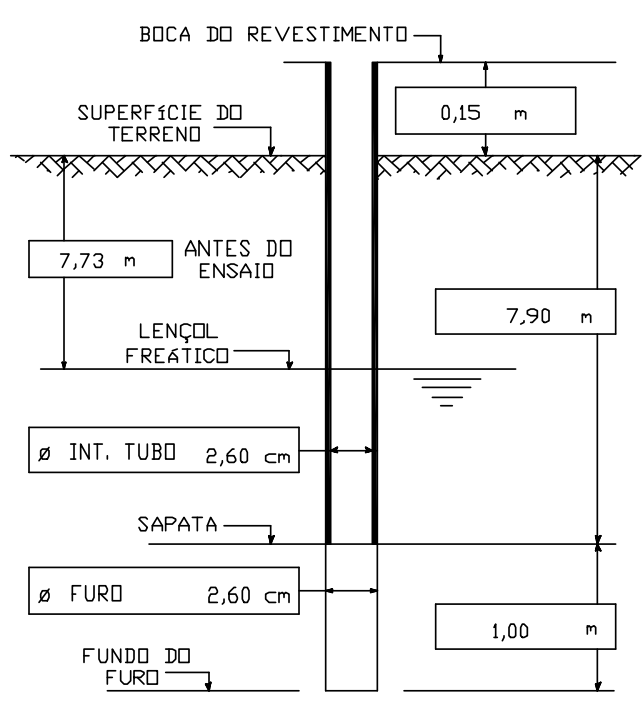

\begin{tabular}{|c|c|c|}
\hline \multicolumn{3}{|c|}{ 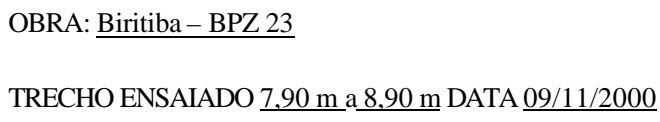 } \\
\hline ENSAIO REALIZADO & \multicolumn{2}{|c|}{ TIPO DE ENSAIO } \\
\hline $\begin{array}{ll}\text { ABAIXO DO N.A. } & \square \\
\text { ACIMA DO N.A. } & \square \\
\text { COM ARTESIANISMO } & \square\end{array}$ & $\begin{array}{l}\text { INFILTRAÇÃO } \\
\text { BOMBEAMENTO } \\
\text { RECUPERAÇÃO } \\
\text { REBAIXAMENTO }\end{array}$ & $\begin{array}{l}\square \\
\square \\
\square\end{array}$ \\
\hline \multicolumn{3}{|c|}{ CONDIÇÕES DE MEDIDAS } \\
\hline \multirow{2}{*}{\multicolumn{2}{|c|}{$\begin{array}{l}\text { TAMBOR } \\
\left(\bullet=\_ \text {cm }\right) \\
\text { REVESTIMENTO }\end{array}$}} & $\square$ \\
\hline & & $\begin{array}{l}\square \\
\square\end{array}$ \\
\hline
\end{tabular}

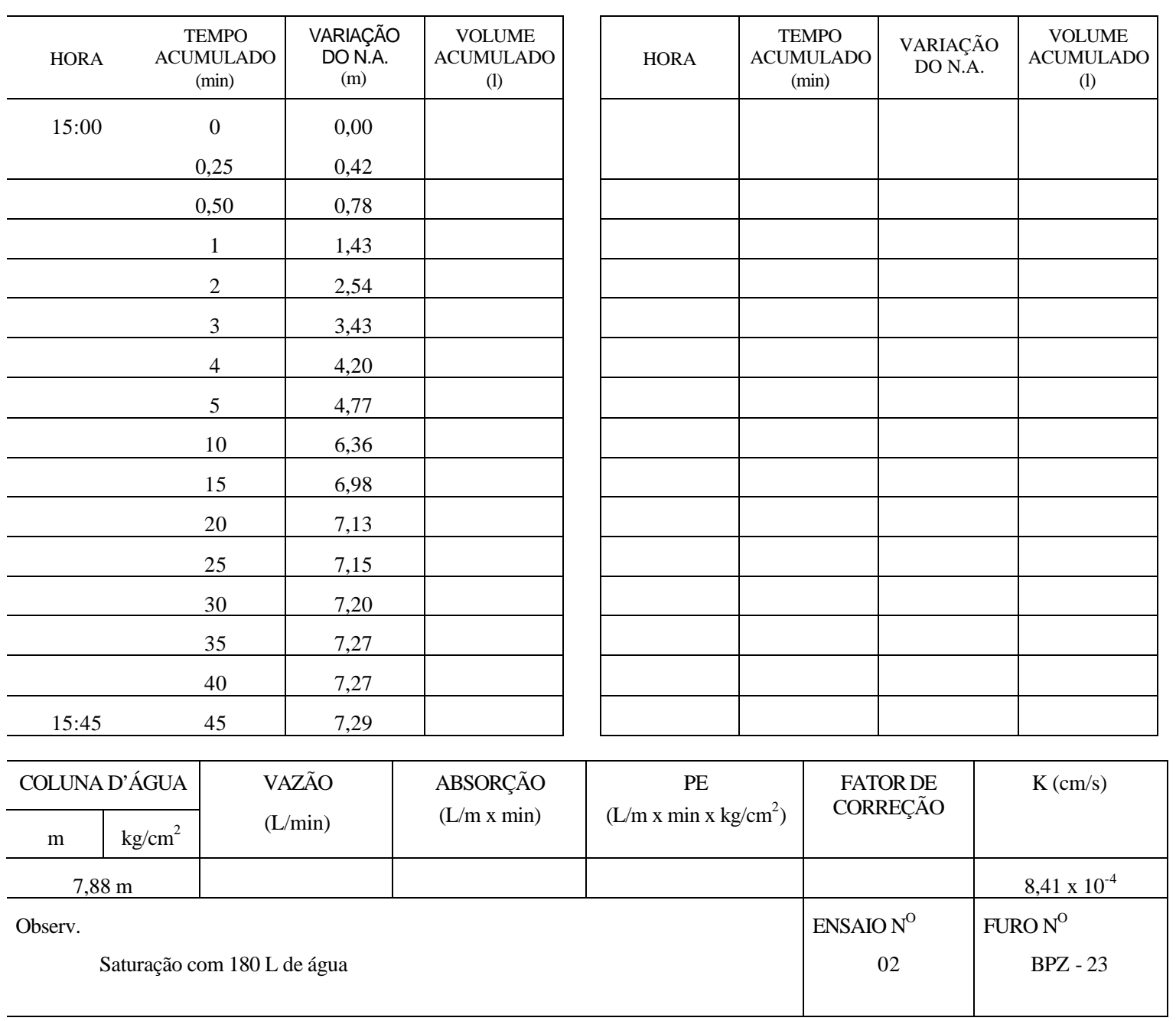




\section{ENSAIO DE PERMEABILIDADE}

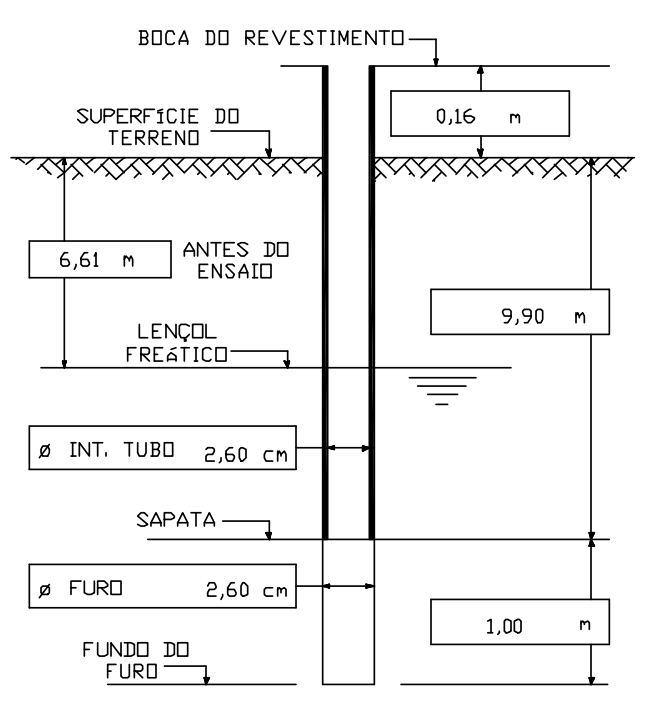

OBRA: Biritiba - BPZ 26

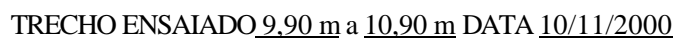

\begin{tabular}{|ll|ll|}
\hline \multicolumn{2}{|c|}{ ENSAIO REALIZADO } & \multicolumn{2}{c|}{ TIPO DE ENSAIO } \\
\hline ABAIXO DO N.A. & $\square$ & INFILTRAÇÃO & $\square$ \\
ACIMA DO N.A. & $\square$ & BOMBEAMENTO & $\square$ \\
COM ARTESIANISMO & $\square$ & RECUPERAÇÃO & $\square$ \\
& & REBAIXAMENTO & $\square$
\end{tabular}

\begin{tabular}{|lll|}
\hline CONDIÇÕES DE MEDIDAS & \\
\hline & TAMBOR__ & \\
& $\left(\bullet=\_\right.$cm $)$ & \\
REVESTIMENTO__ & $\square$ \\
HIDRÔMETRO__ & $\square$ \\
PROVETA__ & $\square$ \\
\hline
\end{tabular}

\begin{tabular}{cc|c|c|}
\hline HORA & $\begin{array}{c}\text { TEMPO } \\
\text { ACUMULADO } \\
(\mathrm{min})\end{array}$ & $\begin{array}{c}\text { VARIAÇÃO } \\
\text { DO N.A. } \\
(\mathrm{m})\end{array}$ & $\begin{array}{c}\text { VOLUME } \\
\text { ACUMULADO } \\
(\mathrm{l})\end{array}$ \\
\hline 0 & 0,00 & \\
\hline 0,25 & 0,46 & \\
\hline 0,50 & 0,67 & \\
\hline 1 & 1,04 & \\
\hline 2 & 1,61 & \\
\hline 3 & 2,03 & \\
\hline 4 & 2,41 & \\
\hline 5 & 2,77 & \\
\hline 10 & 3,83 & \\
\hline 15 & 4,51 & \\
\hline 20 & 5,00 & \\
\hline 25 & 5,36 & \\
\hline 30 & 5,60 & \\
\hline 35 & 5,80 & \\
\hline 40 & 5,91 & \\
\hline 45 & 5,98 & \\
\hline & & \\
\hline
\end{tabular}

\begin{tabular}{|l|c|c|c|}
\hline HORA & $\begin{array}{c}\text { TEMPO } \\
\text { ACUMULADO } \\
(\text { min) }\end{array}$ & $\begin{array}{c}\text { VARIAC̃̃O } \\
\text { DO N.A. }\end{array}$ & $\begin{array}{c}\text { VOLUME } \\
\text { ACUMUADO } \\
\text { (l) }\end{array}$ \\
\hline & & & \\
\hline & & & \\
\hline & & & \\
\hline & & & \\
\hline & & & \\
\hline & & & \\
\hline & & & \\
\hline & & & \\
\hline & & & \\
\hline & & & \\
\hline & & & \\
\hline & & & \\
\hline & & & \\
\hline & & & \\
\hline
\end{tabular}

\begin{tabular}{|c|c|c|c|c|c|c|}
\hline \multicolumn{2}{|c|}{ COLUNA D'ÁGUA } & \multirow{2}{*}{$\begin{array}{l}\text { VAZÃO } \\
\text { (L/min) }\end{array}$} & \multirow{2}{*}{$\begin{array}{l}\text { ABSORÇÃO } \\
(\mathrm{L} / \mathrm{m} \text { x min) }\end{array}$} & \multirow{2}{*}{$\begin{array}{c}\mathrm{PE} \\
\left(\mathrm{L} / \mathrm{m} \times \min \times \mathrm{kg} / \mathrm{cm}^{2}\right)\end{array}$} & \multirow{2}{*}{$\begin{array}{c}\text { FATOR DE } \\
\text { CORREÇÃO }\end{array}$} & \multirow[t]{2}{*}{$\mathrm{K}(\mathrm{cm} / \mathrm{s})$} \\
\hline $\mathrm{m}$ & $\mathrm{kg} / \mathrm{cm}^{2}$ & & & & & \\
\hline \multicolumn{2}{|c|}{6,77} & & & & & $3,94 \times 10^{-4}$ \\
\hline \multirow{2}{*}{\multicolumn{3}{|c|}{ Saturacão com 150 L de água }} & \multirow{2}{*}{\multicolumn{2}{|c|}{ (use verso se necessário) }} & ENSAIO N $^{\mathrm{O}}$ & FURO N ${ }^{O}$ \\
\hline & & & & & 03 & BPZ - 26 \\
\hline
\end{tabular}




\section{ENSAIO DE PERMEABILIDADE}

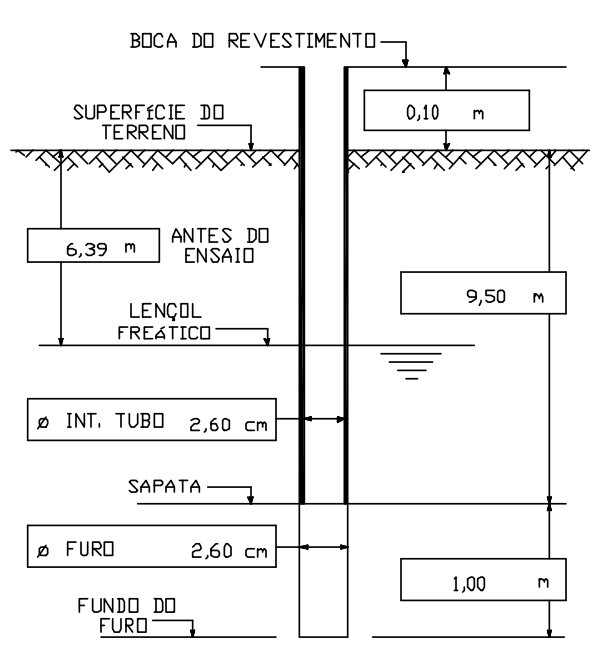

\begin{tabular}{|c|c|c|}
\hline \multicolumn{3}{|c|}{ 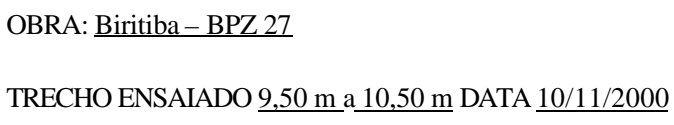 } \\
\hline ENSAIO REALIZADO & \multicolumn{2}{|c|}{ TIPO DE ENSAIO } \\
\hline $\begin{array}{l}\text { ABAIXO DO N.A. } \\
\text { ACIMA DO N.A. } \\
\text { COM ARTESIANISMO }\end{array}$ & $\begin{array}{l}\text { INFILTRAÇÃO } \\
\text { BOMBEAMENTO } \\
\text { RECUPERAÇÃO } \\
\text { REBAIXAMENTO }\end{array}$ & $\begin{array}{l}\square \\
\square \\
\square\end{array}$ \\
\hline \multicolumn{3}{|c|}{ CONDIÇÕES DE MEDIDAS } \\
\hline REBAIXAMENTO & $\begin{array}{l}\left.\mathrm{BOR} \_\mathrm{cm}\right) \\
\mathrm{ESTIMENTO}\end{array}$ & $\square$ \\
\hline HIDRÔMETRO_ & & $\square$ \\
\hline PROVETA & & $\square$ \\
\hline
\end{tabular}

\begin{tabular}{cc|c|c|}
\hline HORA & $\begin{array}{c}\text { TEMPO } \\
\text { ACUMULADO } \\
(\mathrm{min})\end{array}$ & $\begin{array}{c}\text { VARIAÇÃO } \\
\text { DO N.A. } \\
(\mathrm{m})\end{array}$ & $\begin{array}{c}\text { VOLUME } \\
\text { ACUMULADO } \\
(\mathrm{l})\end{array}$ \\
\hline 0 & 0,000 & \\
\hline 0,25 & 1,000 & \\
\hline 0,50 & 1,760 & \\
\hline 1 & 2,940 & \\
\hline 2 & 4,180 & \\
\hline 3 & 4,950 & \\
\hline 4 & 5,480 & \\
\hline 5 & 5,610 & \\
\hline 10 & 5,980 & \\
\hline 15 & 5,980 & \\
\hline 20 & 6,070 & \\
\hline 25 & 6,080 & \\
\hline 30 & 6,140 & \\
\hline 35 & 6,210 & \\
\hline 40 & 6,230 & \\
\hline 45 & 6,250 & \\
\hline & & \\
\hline
\end{tabular}

\begin{tabular}{|l|c|l|c|}
\hline HORA & $\begin{array}{c}\text { TEMPO } \\
\text { ACUMU) } \\
(\mathrm{min})\end{array}$ & $\begin{array}{c}\text { VARIAÇÃO } \\
\text { DO N.A. }\end{array}$ & $\begin{array}{c}\text { VOLUME } \\
\text { ACUMULADO } \\
(\mathrm{l})\end{array}$ \\
\hline & & & \\
\hline & & & \\
\hline & & & \\
\hline & & & \\
\hline & & & \\
\hline & & & \\
\hline & & & \\
\hline & & & \\
\hline & & & \\
\hline & & & \\
\hline
\end{tabular}

\begin{tabular}{|c|c|c|c|c|c|c|}
\hline \multicolumn{2}{|c|}{ COLUNA D'ÁGUA } & \multirow{2}{*}{$\begin{array}{l}\text { VAZÃO } \\
(\mathrm{L} / \mathrm{min})\end{array}$} & \multirow{2}{*}{$\begin{array}{c}\text { ABSORÇÃO } \\
(\mathrm{L} / \mathrm{m} \times \mathrm{min})\end{array}$} & \multirow{2}{*}{$\begin{array}{c}\mathrm{PE} \\
\left(\mathrm{L} / \mathrm{m} \times \min \times \mathrm{kg} / \mathrm{cm}^{2}\right)\end{array}$} & \multirow{2}{*}{$\begin{array}{c}\text { FATOR DE } \\
\text { CORREÇÃO }\end{array}$} & \multirow[t]{2}{*}{$\mathrm{K}(\mathrm{cm} / \mathrm{s})$} \\
\hline $\mathrm{m}$ & $\mathrm{kg} / \mathrm{cm}^{2}$ & & & & & \\
\hline \multicolumn{2}{|c|}{6,49} & & & & & $1,43 \times 10^{-3}$ \\
\hline \multirow{2}{*}{\multicolumn{3}{|c|}{ Saturação com 150 L de água }} & \multirow{2}{*}{\multicolumn{2}{|c|}{ (use verso se necessário) }} & ENSAIO $\mathrm{N}^{\mathrm{O}}$ & FURO N ${ }^{O}$ \\
\hline & & & & & 04 & BPZ - 27 \\
\hline
\end{tabular}




\section{ANEXO F}

Resultados do monitoramento de poços da bacia de drenagem do rio Biritiba-Mirim 
TABELA F1 - Monitoramento do N.A. dos poços instalados na bacia de contribuição do reservatório de Biritiba-Mirim. Dados coletados no período de maio a março de 2001.

\begin{tabular}{|c|c|c|c|c|c|c|c|c|c|c|c|c|}
\hline \multirow{3}{*}{$\begin{array}{l}\mathrm{N}^{\circ} \text { do } \\
\text { Poço }\end{array}$} & \multirow{2}{*}{\multicolumn{3}{|c|}{ Coordenadas UTM (m) }} & \multirow{3}{*}{$\begin{array}{l}\text { Profundidade } \\
\text { do poço }(\mathrm{m})\end{array}$} & \multicolumn{8}{|c|}{ Dados coletados durante o monitoramento $(\mathrm{m})$} \\
\hline & & & & & \multicolumn{2}{|c|}{ maio/junho (2000) } & \multicolumn{2}{|c|}{ setembro $(2000)$} & \multicolumn{2}{|c|}{ dezembro (2000) } & \multicolumn{2}{|c|}{ março (2001) } \\
\hline & $\mathrm{x}$ & $\mathrm{Y}$ & $Z$ & & Prof.N.A.* ${ }^{*}$ & Cota & Prof.N.A.* ${ }^{*}$ & Cota & Prof.N.A. ${ }^{*}$ & Cota & Prof.N.A.* ${ }^{*}$ & Cota \\
\hline $\mathrm{BPZ}-17$ & 391001 & 7388811 & 762,0 & 11,0 & 3,5 & 758,5 & 3,5 & 758,5 & 2,7 & 759,3 & 2,4 & 759,6 \\
\hline $\mathrm{BPZ}-18$ & 389748 & 7387678 & 760,0 & 11,0 & 10,3 & 749,7 & 10,9 & 749,1 & 10,8 & 749,2 & 10,2 & 749,8 \\
\hline $\mathrm{BPZ}-19$ & 389025 & 7385838 & 760,0 & 11,0 & 7,8 & - & - & - & 7,5 & 752,5 & 7,3 & 752,7 \\
\hline BPZ - 22 & 388647 & 7388942 & 753,0 & 14,0 & 12,9 & 740,1 & 13,3 & 739,8 & 13,4 & 739,6 & 13,7 & 739,3 \\
\hline$B P Z-23$ & 388271 & 7387718 & 768,0 & 10,5 & 7,1 & 760,9 & 7,4 & 760,6 & 7,3 & 760,7 & 7,1 & 760,9 \\
\hline $\mathrm{BPZ}-24$ & 388159 & 7385511 & 764,0 & 12,0 & 10,8 & 753,2 & 11,0 & 753,0 & 10,8 & 753,2 & 10,9 & 753,1 \\
\hline $\mathrm{BPZ}-25$ & 390029 & 7381484 & 763,5 & 11,0 & 2,1 & 761,5 & 1,4 & 762,1 & - & - & 1,7 & 761,8 \\
\hline $\mathrm{BPZ}-26$ & 391725 & 7381316 & 774,5 & 11,0 & 7,1 & 767,4 & 6,2 & 768,3 & 4,2 & 770,3 & 6,5 & 768,0 \\
\hline $\mathrm{BPZ}-27$ & 391639 & 7383108 & 765,0 & 11,0 & 6,8 & 758,2 & 6,0 & 759,0 & 5,5 & 759,5 & 5,9 & 759,1 \\
\hline
\end{tabular}

* $:$ N.A. = Nível de Água

- : Ausência de dado 
TABELA F2 -Monitoramento do N.A. dos poços cadastrados na bacia de contribuição do reservatório de Biritiba-Mirim. Dados coletados no período de novembro de 1999 a março de 2001.

\begin{tabular}{|c|c|c|c|c|c|c|c|c|c|c|c|c|c|c|}
\hline \multirow{3}{*}{$\begin{array}{l}\mathrm{N}^{\circ} \text { do } \\
\text { Poço }\end{array}$} & \multirow{2}{*}{\multicolumn{3}{|c|}{ Coordenadas UTM (m) }} & \multirow{2}{*}{\multicolumn{3}{|c|}{$\begin{array}{l}\text { Dados coletados durante o cadastro* } \\
\qquad(\mathrm{m})\end{array}$}} & \multicolumn{8}{|c|}{ Dados coletados durante o monitoramento $(\mathrm{m})$} \\
\hline & & & & & & & \multicolumn{2}{|c|}{ maio/junho (2000) } & \multicolumn{2}{|c|}{ setembro $(2000)$} & \multicolumn{2}{|c|}{ dezembro $(2000)$} & \multicolumn{2}{|c|}{ março (2001) } \\
\hline & $\mathrm{X}$ & $\mathrm{Y}$ & $\mathrm{Z}$ & Prof. do Poço & Prof.N.A. ${ }^{\star \star}$ & Cota & Prof.N.A. ${ }^{*}$ & Cota & Prof.N.A.* & Cota & Prof.N.A.* & Cota & Prof.N.A.* & Cota \\
\hline $\mathrm{BM}-01$ & 390397 & 7389799 & 795,0 & 19,3 & 17,30 & 777,7 & 15,4 & 779,6 & 16,4 & 778,6 & 16,8 & 778,2 & 15,9 & 779,1 \\
\hline BM - 02 & 390847 & 7389534 & 770,0 & 12,0 & 11,12 & 758,9 & 10,5 & 759,5 & 10,5 & 759,5 & 11,9 & 758,1 & 10,5 & 759,5 \\
\hline $\mathrm{BM}-03$ & 391310 & 7389622 & 766,0 & 10,1 & 7,39 & 758,6 & 5,7 & 760,3 & 6,9 & 759,1 & 2,8 & 763,2 & 3,2 & 762,9 \\
\hline $\mathrm{BM}-04$ & 393146 & 7390200 & 792,0 & 22,7 & 21,79 & 770,2 & 20,5 & 771,5 & 21,3 & 770,7 & 21,3 & 770,7 & 21,0 & 771,0 \\
\hline BM - 05 & 393567 & 7389877 & 783,0 & 6,0 & 2,89 & 780,1 & 2,6 & 780,4 & 2,9 & 780,1 & 2,7 & 780,3 & 2,5 & 780,5 \\
\hline $\mathrm{BM}-06$ & 393179 & 7389734 & 767,0 & 4,9 & 3,17 & 763,8 & 2,5 & 764,5 & 2,7 & 764,4 & 2,4 & 764,6 & 2,2 & 764,8 \\
\hline $\mathrm{BM}-07$ & 393283 & 7389468 & 807,0 & 24,4 & 23,37 & 783,6 & 21,5 & 785,5 & 21,7 & 785,3 & 21,4 & 785,6 & seco & seco \\
\hline $\mathrm{BM}-08$ & 392999 & 7388643 & 775,0 & 6,1 & 2,69 & 772,3 & 2,7 & 772,3 & 2,6 & 772,4 & 2,0 & 773,0 & 1,9 & 773,1 \\
\hline BM - 09 & 393323 & 7388936 & 798,0 & 8,4 & 7,60 & 790,4 & 7,4 & 790,7 & 7,7 & 790,3 & 7,3 & 790,8 & 7,5 & 790,5 \\
\hline $\mathrm{BM}-10$ & 392379 & 7389607 & 762,0 & 4,1 & 2,29 & 759,7 & 2,0 & 760,0 & 1,8 & 760,2 & 1,5 & 760,5 & 1,3 & 760,7 \\
\hline BM - 11 & 392144 & 7387649 & 770,0 & 11,3 & 9,66 & 760,3 & 8,5 & 761,5 & 9,2 & 760,9 & 8,9 & 761,1 & 8,9 & 761,1 \\
\hline $\mathrm{BM}-12$ & 391571 & 7387646 & 763,0 & 3,9 & 3,20 & 759,8 & 2,4 & 760,6 & 2,9 & 760,1 & 2,1 & 760,9 & 2,2 & 760,8 \\
\hline $\mathrm{BM}-13$ & 391900 & 7387152 & 767,0 & 6,2 & 5,56 & 761,4 & 3,6 & 763,4 & 4,3 & 762,8 & 2,4 & 764,6 & 2,2 & 764,8 \\
\hline $\mathrm{BM}-14$ & 390808 & 7387333 & 772,0 & 10,7 & 9,49 & 762,5 & 8,0 & 764,1 & 9,0 & 763,0 & 7,8 & 764,2 & 7,0 & 765,0 \\
\hline BM - 15 & 391009 & 7387121 & 761,0 & 9,3 & 7,00 & 754,0 & 6,6 & 754,4 & 7,0 & 754,0 & 6,2 & 754,8 & 6,5 & 754,5 \\
\hline BM - 16 & 391533 & 7386576 & 770,0 & 6,1 & 5,30 & 764,7 & 4,8 & 765,2 & 4,9 & 765,1 & 4,6 & 765,4 & 4,3 & 765,7 \\
\hline BM - 17 & 390183 & 7387828 & 758,0 & 5,9 & 3,94 & 754,1 & 3,7 & 754,3 & 4,4 & 753,6 & 2,8 & 755,2 & 3,8 & 754,2 \\
\hline $\mathrm{BM}-18$ & 390308 & 7388196 & 764,0 & 8,6 & 7,21 & 756,8 & 6,1 & 757,9 & 6,4 & 757,6 & 5,7 & 758,3 & 5,7 & 758,3 \\
\hline $\mathrm{BM}-19$ & 389082 & 7387241 & 776,0 & 12,1 & 7,96 & 768,0 & 7,6 & 768,4 & 7,8 & 768,2 & 6,7 & 769,3 & 6,3 & 769,7 \\
\hline $\mathrm{BM}-20$ & 389793 & 7386655 & 763,0 & 5,5 & 4,08 & 758,9 & - & - & 4,1 & 758,9 & 3,4 & 759,6 & 3,7 & 759,4 \\
\hline $\mathrm{BM}-21$ & 390244 & 7387025 & 765,0 & 4,4 & 2,29 & 762,7 & 2,2 & 762,8 & 2,2 & 762,8 & 1,9 & 763,2 & 2,0 & 763,1 \\
\hline BM - 22 & 388837 & 7384453 & 762,0 & 5,8 & 4,71 & 757,3 & 5,2 & 756,8 & 4,6 & 757,4 & 3,5 & 758,5 & 4,1 & 757,9 \\
\hline $\mathrm{BM}-23$ & 387739 & 7388612 & 765,0 & 16,8 & 14,64 & 750,4 & 13,2 & 751,8 & 14,1 & 750,9 & 14,7 & 750,3 & 13,2 & 751,8 \\
\hline BM - 24 & 386742 & 7388185 & 765,0 & 2,4 & 1,74 & 763,3 & 1,7 & 763,3 & 1,6 & 763,4 & 1,4 & 763,6 & 1,5 & 763,5 \\
\hline BM - 25 & 386810 & 7387786 & 770,0 & 14,0 & 12,44 & 757,6 & 9,8 & 760,3 & 11,1 & 758,9 & 11,6 & 758,4 & 9,5 & 760,5 \\
\hline BM - 26 & 388582 & 7388014 & 749,0 & 3,6 & 2,33 & 746,7 & 2,2 & 746,8 & 2,2 & 746,8 & 2,0 & 747,0 & 2,2 & 746,9 \\
\hline BM -27 & 387841 & 7387792 & 765,0 & 3,4 & 1,82 & 763,2 & 1,8 & 763,2 & 1,8 & 763,2 & 2,5 & 762,5 & 2,1 & 763,0 \\
\hline
\end{tabular}

* : meses de novembro e dezembro de 1999

** $:$ N.A. = Nível de Água

*** : Nível dinâmico

- : Ausência de dado 
(continuação)

TABELA F2 -Monitoramento do N.A. dos poços cadastrados na bacia de contribuição do reservatório de Biritiba-Mirim. Dados coletados no período de novembro de 1999 a março de 2001.

\begin{tabular}{|c|c|c|c|c|c|c|c|c|c|c|c|c|c|c|}
\hline \multirow{3}{*}{$\begin{array}{l}N^{\circ} \text { do } \\
\text { Poço }\end{array}$} & \multirow{2}{*}{\multicolumn{3}{|c|}{ Coordenadas UTM (m) }} & \multirow{2}{*}{\multicolumn{3}{|c|}{$\begin{array}{l}\text { Dados coletados durante o cadastro* } \\
\qquad(\mathrm{m})\end{array}$}} & \multicolumn{8}{|c|}{ Dados coletados durante o monitoramento $(\mathrm{m})$} \\
\hline & & & & & & & \multicolumn{2}{|c|}{ maio/junho $(2000)$} & \multicolumn{2}{|c|}{ setembro $(2000)$} & \multicolumn{2}{|c|}{ dezembro $(2000)$} & \multicolumn{2}{|c|}{ março (2001) } \\
\hline & $\mathrm{X}$ & $\mathrm{Y}$ & $Z$ & Prof. do Poço & Prof.N.A. ${ }^{* \star}$ & Cota & Prof.N.A.** & Cota & Prof.N.A.**' & Cota & Prof.N.A.*' & Cota & Prof.N.A.** & Cota \\
\hline BM - 28 & 387397 & 7387822 & 770,0 & 18,4 & 16,91 & 753,1 & 15,8 & 754,2 & 16,2 & 753,9 & 16,9 & 753,1 & 16,1 & 753,9 \\
\hline BM - 29 & 387029 & 7387247 & 768,0 & 4,2 & 2,85 & 765,2 & 3,1 & 764,9 & 3,1 & 764,9 & 2,7 & 765,3 & 2,9 & 765,1 \\
\hline $\mathrm{BM}-30$ & 386488 & 7387616 & 762,0 & 4,8 & 2,50 & 759,5 & 2,5 & 759,5 & 2,6 & 759,4 & 2,0 & 760,0 & 2,3 & 759,7 \\
\hline $\mathrm{BM}-31$ & 388598 & 7384566 & 759,0 & 3,9 & 3,18 & 755,8 & 3,1 & 755,9 & 3,1 & 755,9 & 2,7 & 756,3 & 3,0 & 756,0 \\
\hline $\mathrm{BM}-32$ & 388216 & 7384926 & 770,0 & 9,2 & 6,67 & 763,3 & 5,8 & 764,2 & 6,0 & 764,0 & 5,9 & 764,1 & 6,2 & 763,8 \\
\hline BM - 33 & 387704 & 7385237 & 759,0 & 5,1 & 3,22 & 755,8 & 3,2 & 755,8 & 3,1 & 755,9 & 2,4 & 756,6 & 2,1 & 756,9 \\
\hline $\mathrm{BM}-34$ & 387735 & 7386606 & 768,0 & 5,4 & 4,60 & 763,4 & 4,1 & 763,9 & 4,3 & 763,7 & 3,5 & 764,5 & 4,0 & 764,0 \\
\hline $\mathrm{BM}-35$ & 387472 & 7385871 & 768,0 & 4,7 & 3,60 & 764,4 & - & - & 3,4 & 764,6 & 2,6 & 765,4 & 3,5 & 764,6 \\
\hline $\mathrm{BM}-36$ & 387207 & 7385679 & 770,0 & 4,1 & 2,45 & 767,6 & 2,0 & 768,0 & 1,8 & 768,2 & 1,3 & 768,7 & 1,8 & 768,3 \\
\hline $\mathrm{BM}-37$ & 387077 & 7384911 & 770,0 & 6,1 & 4,40 & 765,6 & 3,3 & 766,7 & 3,2 & 766,8 & 3,1 & 766,9 & 3,1 & 766,9 \\
\hline BM - 38 & 387676 & 7384489 & 780,0 & 36,8 & 6,94 & 773,1 & - & - & 3,8 & 776,2 & 3,6 & 776,4 & 4,3 & 775,7 \\
\hline BM - 39 & 387655 & 7383758 & 785,0 & 4,9 & 4,45 & 780,6 & 3,7 & 781,3 & 3,8 & 781,2 & 2,3 & 782,7 & 2,9 & 782,1 \\
\hline $\mathrm{BM}-40$ & 387147 & 7384036 & 772,0 & 7,6 & 5,70 & 766,3 & - & - & 5,3 & 766,7 & 4,1 & 767,9 & 5,2 & 766,8 \\
\hline $\mathrm{BM}-41$ & 386755 & 7384018 & 785,0 & $22,5^{\star \star \star}$ & 21,45 & 763,6 & 20,8 & 764,2 & 21,1 & 763,9 & 20,6 & 764,4 & 21,0 & 764,0 \\
\hline $\mathrm{BM}-42$ & 386760 & 7383299 & 765,0 & 3,2 & 1,90 & 763,1 & 1,7 & 763,3 & 1,8 & 763,2 & 1,6 & 763,4 & 1,8 & 763,2 \\
\hline $\mathrm{BM}-43$ & 387859 & 7383157 & 769,0 & 12,3 & 11,97 & 757,0 & 10,7 & 758,3 & 11,6 & 757,4 & 11,5 & 757,5 & 11,7 & 757,3 \\
\hline $\mathrm{BM}-44$ & 388304 & 7383280 & 763,0 & 4,8 & 4,10 & 758,9 & 3,7 & 759,3 & 3,7 & 759,3 & 3,4 & 759,6 & 3,6 & 759,4 \\
\hline $\mathrm{BM}-45$ & 387582 & 7382498 & 762,0 & 6,1 & 5,50 & 756,5 & 5,1 & 756,9 & 5,2 & 756,8 & 4,2 & 757,8 & 5,4 & 756,6 \\
\hline $\mathrm{BM}-46$ & 387484 & 7381795 & 770,0 & 6,8 & 5,25 & 764,8 & 5,1 & 765,0 & 5,1 & 764,9 & 4,9 & 765,1 & 5,9 & 764,1 \\
\hline BM - 47 & 387712 & 7382011 & 770,0 & 13,6 & 12,60 & 757,4 & 12,3 & 757,7 & 12,5 & 757,5 & 12,0 & 758,1 & 12,5 & 757,5 \\
\hline $\mathrm{BM}-48$ & 387869 & 7381367 & 770,0 & 3,0 & 1,75 & 768,3 & 1,6 & 768,4 & 0,6 & 769,5 & 0,3 & 769,7 & 0,9 & 769,1 \\
\hline BM - 49 & 388249 & 7380713 & 768,0 & 7,4 & 4,20 & 763,8 & 5,7 & 762,3 & 3,9 & 764,1 & 2,8 & 765,2 & 4,1 & 763,9 \\
\hline $\mathrm{BM}-50$ & 388159 & 7381993 & 759,0 & 6,9 & 5,20 & 753,8 & 5,5 & 753,5 & 5,2 & 753,8 & 4,5 & 754,5 & 5,2 & 753,8 \\
\hline $\mathrm{BM}-51$ & 389031 & 7382182 & 770,0 & 5,4 & 2,45 & 767,6 & 3,0 & 767,0 & 3,6 & 766,4 & 1,7 & 768,4 & 2,9 & 767,1 \\
\hline BM - 52 & 387962 & 7380923 & 768,0 & 2,8 & 1,01 & 767,0 & 0,9 & 767,1 & 0,8 & 767,2 & 0,7 & 767,3 & 1,0 & 767,0 \\
\hline BM - 53 & 389379 & 7381746 & 776,0 & 8,9 & 6,70 & 769,3 & 7,3 & 768,7 & 7,5 & 768,5 & 7,0 & 769,0 & 7,4 & 768,6 \\
\hline BM - 54 & 389461 & 7381198 & 765,0 & 5,9 & 3,00 & 762,0 & - & - & 3,0 & 762,0 & 2,6 & 762,4 & 3,0 & 762,1 \\
\hline BM -55 & 389452 & 7380287 & 757,0 & 4,1 & 2,50 & 754,5 & 3,0 & 754,0 & 2,7 & 754,3 & 2,0 & 755,0 & 2,7 & 754,3 \\
\hline
\end{tabular}

(continua) 
(continuação)

TABELA F2 -Monitoramento do N.A. dos poços cadastrados na bacia de contribuição do reservatório de Biritiba-Mirim. Dados coletados no período de novembro de 1999 a março de 2001.

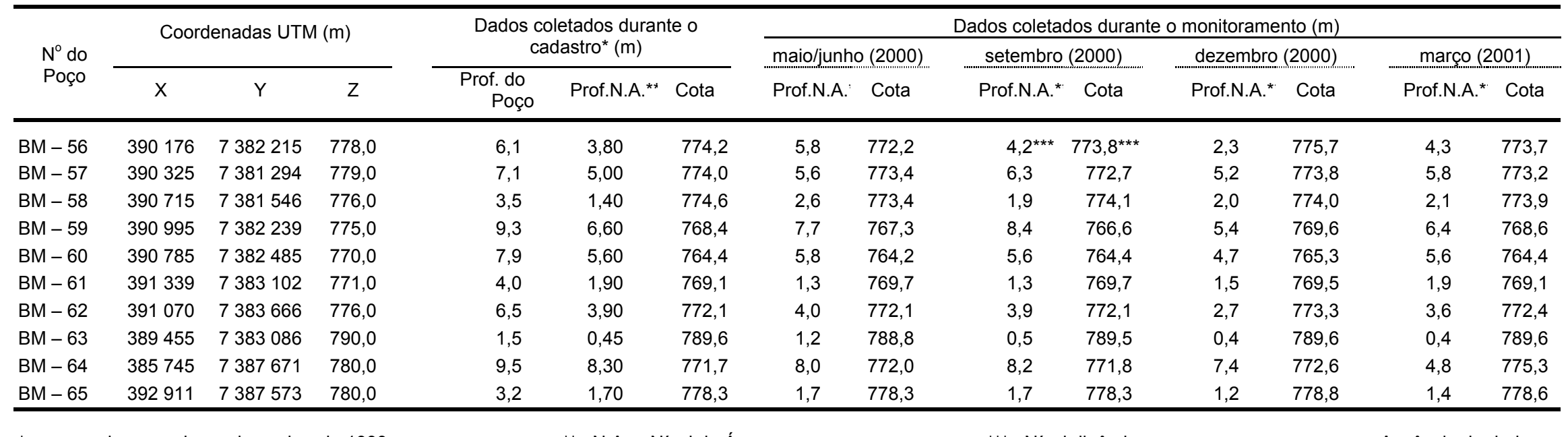

* : meses de novembro e dezembro de 1999

** $:$ N.A. = Nível de Água

*** : Nível dinâmico

- : Ausência de dado 
DESENHOS 



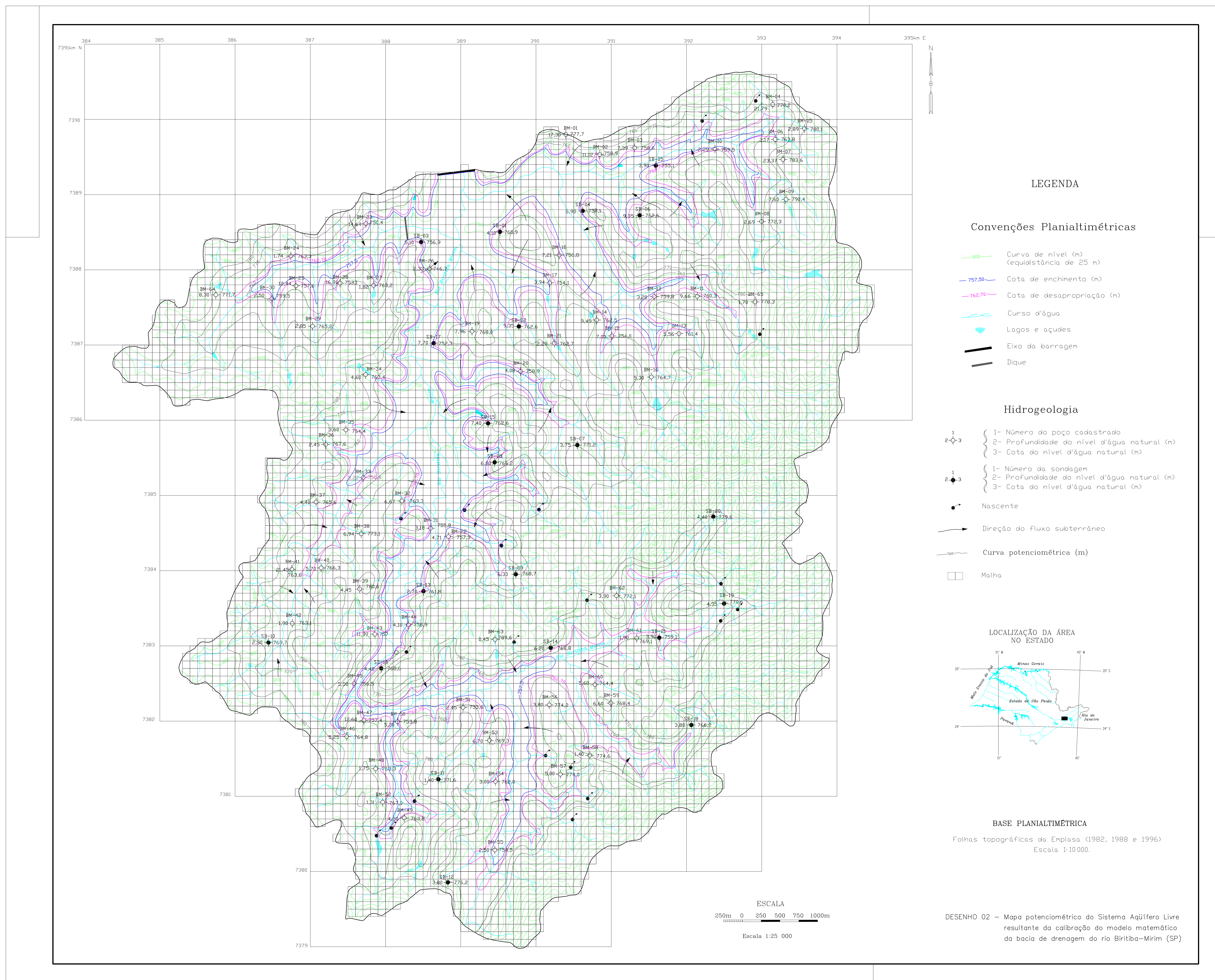




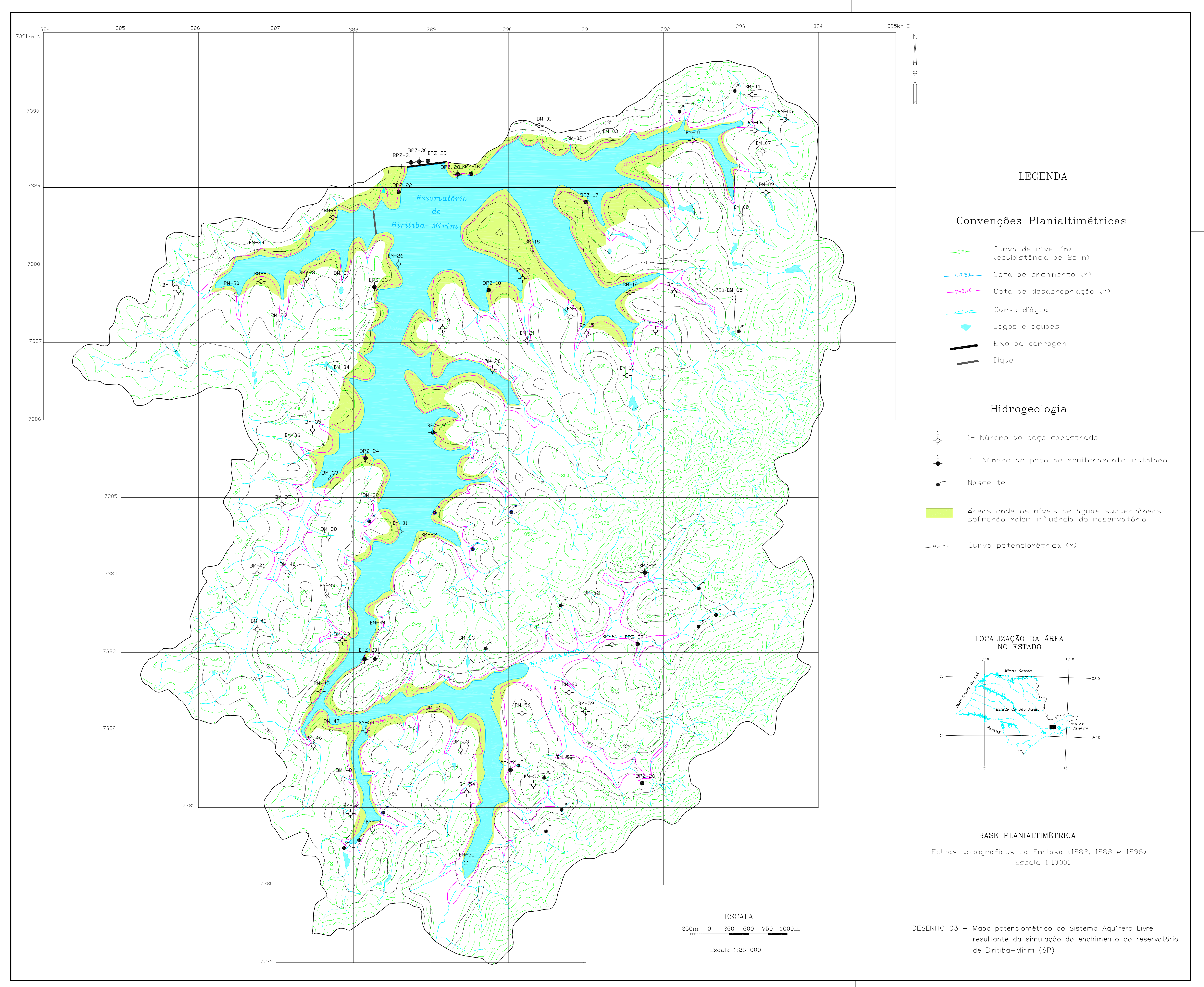




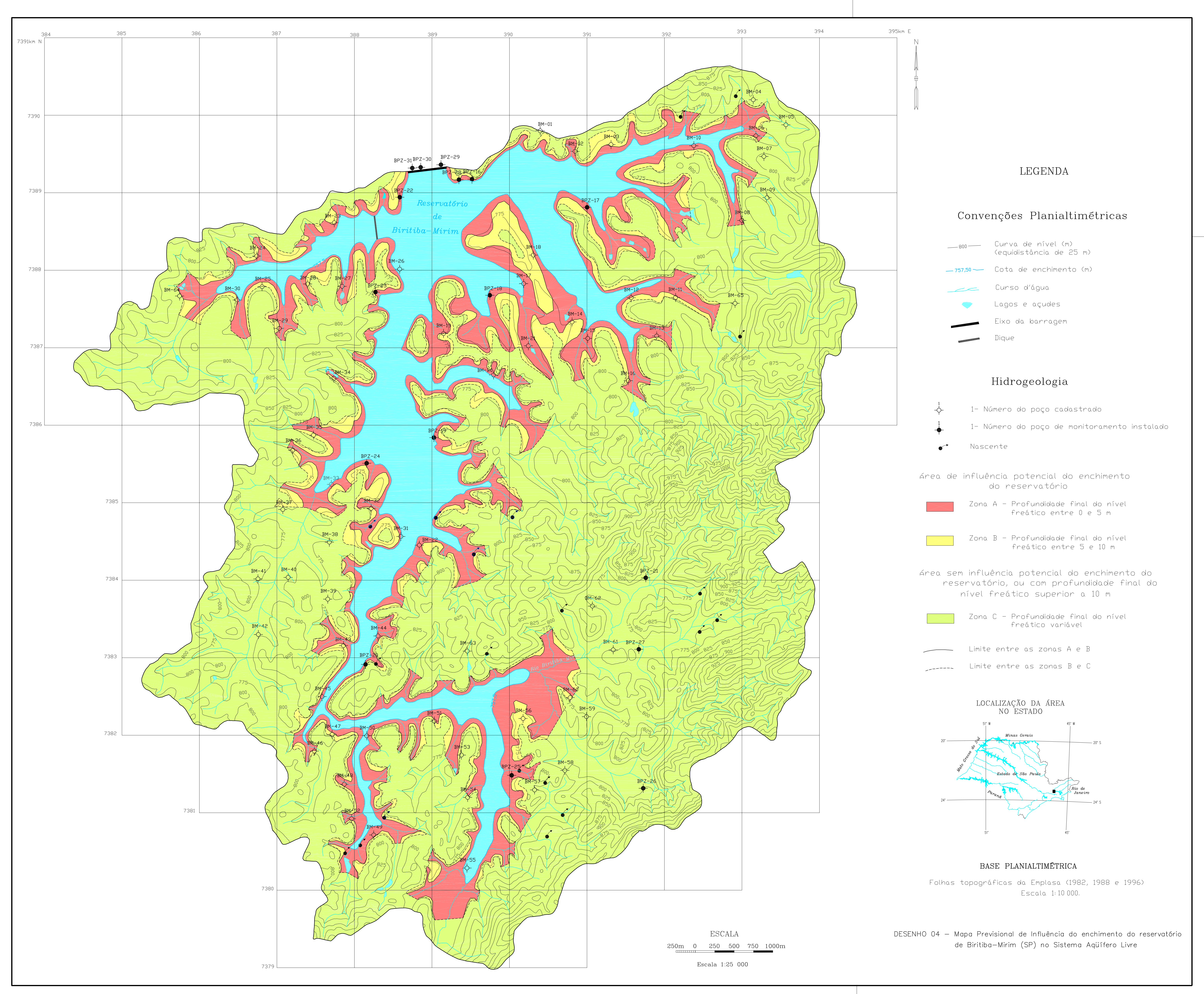

